

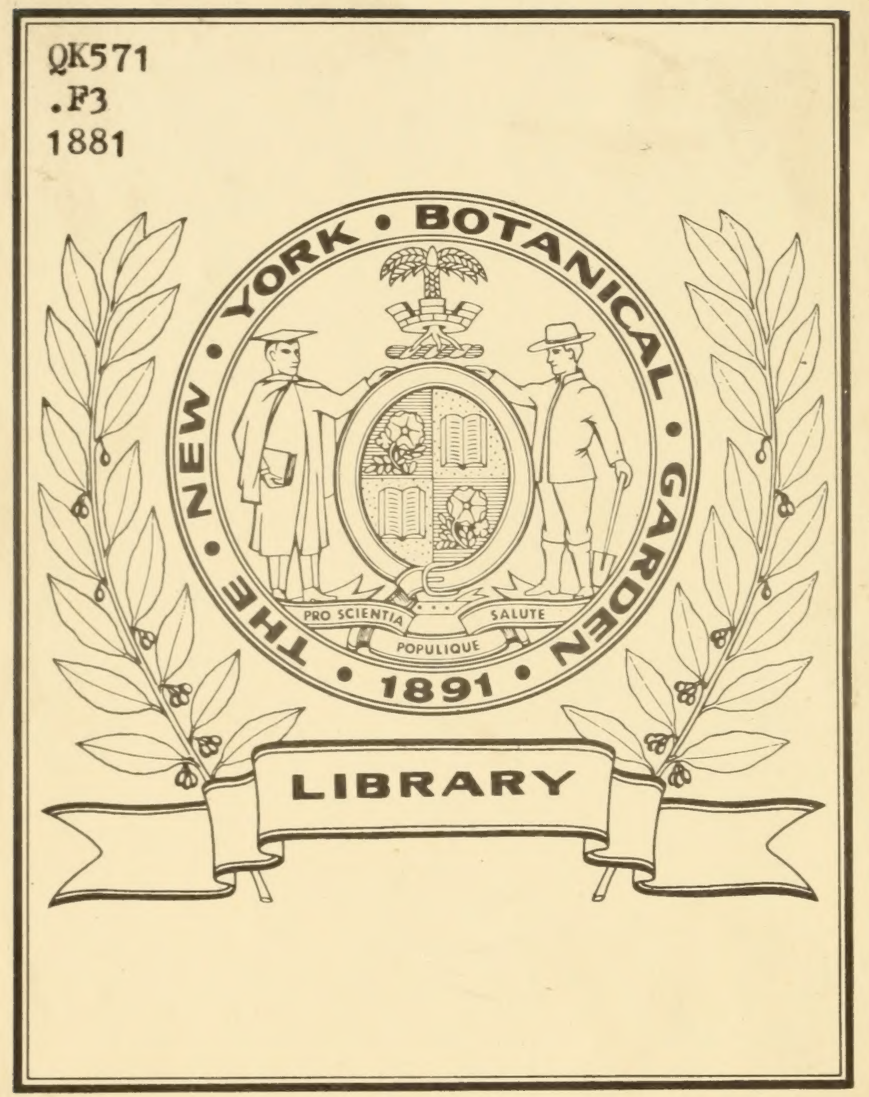






\section{MARINE ALGÆ}

$$
\begin{aligned}
& \text { N. L. Britton. } \\
& \text { of fan. 16, } 1882 .
\end{aligned}
$$
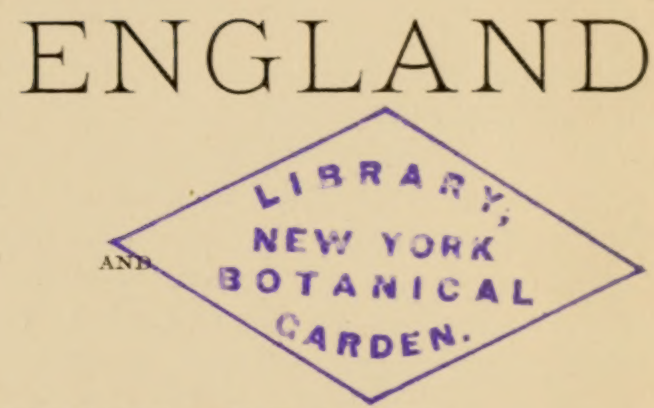

ADJACENT COAST.

BY

W. G. FARLOW, M. D.

[REPRINTED FROM REPORT OF U. S. FISH COMMISSION FOR 1879.]

W A SHING TON :

GOVERNMENT PRINTING OFFICE.

I 88 I. 
$Q K 571$

. F3

1881 


\section{THE MARINE ALGE OF NEW ENGLAND.}

By Prof. W. G. FARLOW.

\section{INTRODUCTION.}

This report is intended, with the exception of the Diatomes, to include all the marine species at present known to occur on the coast of the United States from New Jersey to Eastport, Me., and a few species are mentioned which, although they have not yet been found within our limits, are nevertheless to be expected from the fact that they occur on the neighboring coast of the British provinces. In preparing the report I have attempted to present, in a compact and more or less popular form, a description of the different orders and species of sea-weeds, so that persons who frequent the coast of New England, and especially those in the service of the Fish Commission, may have at hand the means of determining the forms found in our waters. The deseriptive portion of the report is preceded by a short account of the general structure and classification of sea-weeds, which is necessary in the present ease, because there is no generally accessible book in the English language which gives a good account of the modern views of the classification and structure of algæ.

The list of papers relating directly to New England algæ is very meager. In January, 1847, Prof. J. W. Bailey published in the American Journal of Arts and Sciences a paper entitled Notes on the Algce of the United States. He enumerates 50 species found in New England, but some of the number are apparently erroneously credited to our coast. Two continuations of the article appeared in May, 1847, and July, 1848, in the former of which 19, and in the latter 17, species new to New England are enumerated. In 1847 Mr. S. T. Olney, in the Proceedings of the Providence Franklin Society, published a paper on Rhode Island Plants, in which he mentions 45 species of algæ. Most of the species in the papers above mentioned had been submitted to Prof. W. H. Harvey, of Dublin. The elassie work of Harvey, the Nereis Boreali-Americana, of which the first two parts were published in the Smithsonian Contributions to Knowledge in 1852, and the third part in $\mathbf{1 8 5 7}$, is the only elaborate account ever published with regard to the sea-weeds of the United States, and it has always been the standard authority on the subject. Since the appearance of Harvey's great work comparatively little has been added to our knowledge of the sea-weeds of New England. In the Report of the United States Fish 
Commission for 1870-'72 is a List of the Marine Algce of the South Coast of New England, in which 103 species are enumerated; and in the report for 1875 is a List of the Marine Algce of the United States, intended as a catalogue of the sea-weeds exhibited by the Commission at the Centennial Exposition, in which additions were made to the New England flora. Besides the papers referred to, I would mention Algoe Rhodiacece, by S.T. Olney, published in 1871; List of Marine Algce Collected near Eastport, $M e$., by Prof. D. C. Eaton*; two papers by the writer in the Proceedings of the American Academy of Boston †; and List of the Marine Algee growing in Long Island Sound within 20 miles of New Haven, by F. W. Hallț. A series of dried specimens has been published conjointly by Dr. C. L. Anderson, Prof. D. C. Eaton, and myself, under the title of Algce Am.-Borealis. The 130 species already published, in three fasciculi of 30 sets each, contain a number of the more interesting New England forms. A set has been presented to the Fish Commission, and that, together with the large set prepared for the Centennial Exhibition, to be deposited hereafter in the National Museum, will place in the hands of the members of the Commission sufficient material to render the task of determining our species comparatively easy.

It will be seen that we rely almost wholly on Harvey's Nereis for our knowledge of New England algæ, and it is surprising that so few species have been added to the flora in recent years. Of the species recently added, by far the larger number are insignificant in size, the rare $N e$ mastoma Bairdii being almost the only species which would attract the eye by its beauty. Professor Harvey himself spent but a few weeks on the New England coast, and we must either suppose that the collectors of Harvey's time were more acute than those of the last few years, or else that the New England flora is very poor. That the flora is not very rich in species, even for a temperate region, is probably true, but it is too soon to assume that it is exceptionally poor.

The number of species which are so large and striking as to attract the amateur collector is nowhere large in temperate regions, and the so-called richness of a flora is generally dependent upon the number of small and insignificant species, which are recognized only by those who make a careful microscopic study. One reason for the apparent poverty of our marine flora is that our collectors have generally been amateurs, who pass a few weeks upon the shore and gather only the more beautiful and striking species. The number of persons who make microscopic examinations of our algæ is, however, increasing, and, as a result, numbers of small, but interesting, species have within a short space of time been brought to light, and it now seems likely that the New England flora is by no means so poor as was formerly supposed. The sever-

* Trans. Conn. Acad., vol. ii, part 2, 1873.

† List of the Marine Algæ of the United States, Proc. Am. Acad. Art. and Sci., vol. x (n. s. ii), p. 351 . On some Algæ new to the United States, l. c., vol. xii (n. s. iv), p. 235 .

$\ddagger$ Bulletin of the Torrey Botanical Club, vol. vi, No. 21, Sept., 1876. 
ity of the climate, too, renders it difficult to collect during the winter and early spring months, when the species to be found are to a great extent different from those which flourish in summer. A rich harvest might be expected by an algologist who should pass the winter and spring at some exposed point upon the coast. The summer species may be said to be tolerably well known, but our knowledge of the winter forms is very deficient.

For the purpose of examining the algæe of the coast, I have visited Eastport, Portland, Cape Ann, Wood's Holl, Mass., where I passed two summers with the Commission, Newport, Noank, Conn., and Greenport, L. I. Unfortunately, I have not been able to make any excursions during the winter months, except to the coast near Boston, at Nahant and Marblehead, and my knowledge of the winter species is derived from specimens sent by correspondents.

In this connection I would express my sincere thanks to correspondents who have aided me by specimens and information, and I would acknowledge especially.my obligations to Prof. D. C. Eaton, of New Haven; Mr. Horace Averill and Mr. A. R. Young, of Brooklyn; Mr. C. B. Fuller, of Portland; Mrs. A. L. Davis and Mrs. M. H. Bray, of Gloucester; Miss M. A. Booth, Mrs. Corcoran, Mrs. J. T. Lusk, Mrs. Beebe, Mr. F. S. Collins, and others, whose names are appended to the different species deseribed. I am particularly indebted to the Fish Commission for their valuable aid in enabling me to dredge and collect in various interesting localities in Southern Massachusetts, at Noank, and at Gloncester, and to Mr. Alexander Agassiz for facilities for examining the coast at Newport. With the materials at hand I have attempted to review eritically the species of our coast, and for this purpose it was necessary to compare them with the algæ not only of Great Britain, but of the other shores of Europe. I am, above all, indebted to Dr. Edouard Bornet, of Paris, who has constantly furnished information, both with regard to structure and nomenclature, without which it would have been impossible for me to form an accurate judgment concerning American species. I would also return my thanks to Prof. J. G. Agardh, of Lund; to Prof. J. E. Areschoug, Dr. W. B. Wittrock, and Dr. F. J. Kjellman, of Upsala, through whose kindness I have been able to examine very complete sets of Seandinavian and Arctic algæ, which have a special bearing on the New England flora; to Prof. E. Perceval Wright, of Dublin, who has obligingly allowed me to examine specimens in the Harveyan Herbarium at Trinity College; to M. A. Le Jolis, of Cherbourg, and Prof. J. T. Rostafinski, of Cracow, for valuable notes on Laminaria ; and to Mr. F. Hanck, of Trieste, for sets of Adriatic algæ.

If we regard the marine vegetation of the northeastern coast of the United States as a whole, we see that, beginning at Eastport, we have a strongly marked aretic flora, which is a direct continuation of that of Greenland and Newfoundland. As we proceed southward towards Boston, although the luxuriance of growth is less, the general appear- 
ance of the flora is still unmistakably aretic, if we except a few sheltered localities. The northeru shore of Cape Cod, from its sandy character, is practically destitute of all species of algæ, except a few forms which are here and there found growing on the eel-grass. As soon as we pass to the south of Cape Cod, however, the flora assumes an entirely different aspect. The arctic and Northern European forms have disappeared, except at a few exposed points like Gay Head and Montank, and, in their place, we find a number of species, as Dasya elegans, Rhabdonia tenera, Chondria tenuissima, Sargassum vulgare, characteristic of warmer seas.

The Long Island flora, which may be said to extend from Cape Cod to New Jersey, has a good deal in common with the northern part of the Adriatic. Among the more abundant species are Dasya elegans, Polysiphonia variegata, and, if we accept Zanardini's view, our common Chondria Baileyana and Lomentaria Baileyana are identical with $C$. striolata and $L$. uncinata, all species common near Venice. From New Jersey to Charleston, if we except Norfolk and one or two points on the North Carolina coast, almost no sea-weeds are known, presumably on account of the unfarorable nature of the shore, although, it must be confessed, the coast has never been carefully explored. Even with regard to the coast of New Jersey we have but little information. A number of Floridece, usually growing attached to eel-grass, has been reported from Beesley's Point by Samuel Ashmead,* but it is almost certain that southward from that point, very little is to be expected.

It will be seen that Cape Cod is the dividing line between a marked northern and a southern flora. In fact, the difference between the floræ of Massachusetts Bay and Buzzards Bay, which are only a few miles apart, is greater than the difference between those of Massachusetts Bay and the Bay of Fundy, or between those of Nantucket and Norfolk. This difference in the flora corresponds precisely with what is known of the fauna. That Cape Cod formed a dividing line was known to Harvey, and subsequent observation has only shown, on the one hand, that the flora north of Cape Cod is more decidedly arctic than he supposed, and that, on the other hand, south of the cape it is more decidedly that of warm seas. The general fact of the distinctness of the two floræ is not weakened by the knowledge that we now possess, owing to the investigations of the Fish Commission, of the existence in a few sheltered localities north of Cape Cod of some of the characteristic species of Long Island Sound, and in a few exposed spots south of the cape of northern species. Of the more common species found along: the whole coast of New England, by far the greater part are also common in Europe, as Delesseria sinuosa, Corallina officinalis, Hildenbrandtia rosea, Polysiphonia violacea, $P$. fastigiata, $P$. nigrescens, $P$. urceolata, Rhodymenia palmata, Chondrus crispus, Cystoclonium purpurascens, Ahnfeltia plicata, Phyllophora Brodicei, P. membranifolia, Polyides rotundus, Ceramium rubrum, Ptilota elegans, Leathesia tuberiformis, Chordaria fla-

*Vid. Proceed. Acad. Nat. Sci., Philadelphia, vol vi, p. 147, vol. x, p. 8. 
gelliformis, C. diruricuta. Desmarestiu aculentu, In. riridis, Phyllitis fuscin. Seytosighon lomentarius, the common Fuci and Laminaria, not to mention a large number of Chlorosporea and Cryptophycese. But a very few exclusively American species are found throughout our limits. Most of the purely American species are either contined to the shore sonth of Cape Cod or else to the shore from Boston northwarl. In fart, a good share of our common sea-weets eould be recognizen from the figures in the Phycologia Brittanica.

Let us consider next the eharacteristie species betreen boston and Eastport. In studying these we must turn not to works on the algie of France, or Great Britain, but rather to those on Scandina vian algae. It is especially instruetive to examine the Algae Scandinavice of Professor Aresehoug in connection with our own forms. The resemblance is at onc.. striking. At Lastport we have a magnificent growth of Lamina. rice and Fuci, which predominate orer all other forms. The larger species are even found high up on the shore, and we find growing in pools Sacenhiza dermatoden, Laminaria longicruris, Agarum Turneri, Dictyosiphon hippuroides, Halosaccion ramentaceum, and Monostroma Blytii; at low-water mark Lithothamnion fasciculatum abounds; and Euthore cristutu, Inelesseria sinuosa, I). alata, and Callithamnion Pylaiscei ean easily. he collected without wading. The rocks are covered with crusts of $P e$. trocelis cruenta, and Rulfsia rerrucosa, and the luxuriant Fucus evanesceins. With the exception of Agurum Turneri, which is not found in Europe, but which oceurs in the North Pacific, and C. Pylaiscei, which is peculiar to Ameriea, all the species named are found in the north of Xorway. Euthora cristata does not appear south of Scotland, where it is rare, and Laminaria longicmuris is scarcely known sonth of the northern part of Scotland. As we proceed southwards from Eastport to Nahant, near lioston, we find that the species named disappear into deeper water, and, with the exception of. Monostroma Blyttii, are not generally seen excent when washed ashore. Dictyosiphon hippuroides has not yet been seen south of Eastport, but saccorhiza dermatodea, linown to Harvey only from Xewfoundland, is now known to occur at Marblehead, near Nahant, and IInlosaccion is not rare in deep pools at Gloucester, while Monostroma IBlyttii, in rather a small form, is found on exposed rocks at Little Jahant. Fucus exanescens, which is as abumdant as $F$. resiculosus at Eastport, seems to be replaced on the Massachusetts coast hy F. fur. catus. Calliblepharis ciliata of Harvey's Nereis, found from Cape Ann northwards is now known to be the sime as Rhodophyllis reprecula, a common species on northern coasts. As yet none of the Scandinavian sprecies of Phlacospora have been found with us, but it is not unlikely that they might he found by a botanist who should collect at Eastport in the spring. It is hardly likely that I'llecospore tortilis does not occur with us, for it is not uncommon on the Norwegrian coast, and was collected in Greenland by Dr. Kimlien, of the Howgate expedition. Polysiphonia arctica may perhaps also be expected, as well as Chatopteris plumosa, 
a common species of Greenland and Northeru Europe. Odonthatia dentutu, a common species of Xorthern Europe, has not yet been found within our limits, although it is common at Halifax.

If north of Boston the principal feature of the marine regetation is the enormous mass of large Fuci and Placosporece, the Floridece forning an insignificant part of the flora, the chief feature of the flora south of Cape Corl is the preponderance of Floridere and the comparative insignificance of the Fuci and Phcrosporece. In the case of the sea-reeds of Long. Island Sound we cannot so directly refer them to species of any part of Europe as was possible in the case of the northern flora. Several of the more common and striking species, as I have already said, are identical with or closely related to Adriatic forms. We are not, howerer to push the comparison too far. The derelopment of Fuci and Laminarice in Long Island Sound, althongh meager compared with what we find north of Boston, is far beyond anything we find in the Adriatic, and, on the other hand, we do not have in Long Island Sound the numerous Corallinere and siphonaceous Chlorosporece, which are common in the Adriatic, and which ummistakably inclicate a subtropical flora. Grinnellia americana, 1)asya elegcis, Rhabdonia tenera, Lomentaria Baileyana, Sargassum vulgare, and most of the common species of Long Island Sound, are found as far south as the West Indies.

A consideration of the apparent exceptions to the law of the distribution of sea-weeds on our coast is not without interest. In the cold waters off Gay Head and Block Island, Euthora cristata, in a depauperate form, is sometimes found, and at exposed points we find a decided growth of Laminaria, especially the digitate forms. I'tilota serrata, a typical northern species, has also been found in a much reduced form at the Thimble Islands, near New Haven.

In the town of Gloucester, near the village of Squam, is a small sheet of water called Groose Core. The narrow entrance to the core has been dammed up, and the water from the ocean enters only for a short time at the high tide. In this core, to my surprise, I found Rhabdonia tenera, Gracilaria multipartita, Chondria Baileyana, and a large mass of Polysiphonia Harveyi and P. Olneyi. In short, the flora was entirely different from anything I had ever seen before north of Cape Cod, and entirely different from that of the adjacent shore, where the flora is entirely arctic. Furthermore, Squam is on the northern and inner side of Cape Ann, and as there is no connection of Goose Cove with the southern side of Cape Anu, and inasmuch as no ressels ever enter the core, it is very difficult to account for the presence of the sea-rieeds which grow there. The water which is confined by the dam is much warmer than that of the surrounding ocean, which rould enable the species of warm waters to live if they were once introduced, but how are we to suppose that the spores were brought into the core? It is hard to believe that they could have been brought by currents, for, as a matter of fact, the currents move in the wrong direction to produce such 
an effecet. Certainly, Rhabulonia tenera is quite unknown in any ofluer spot north of Cape Cod, the nearest locality being the colst near Xanturelet, and it is very dithenlt to eonceive that spores of that de licate species would survive in a very cold eurrent, which not only must carry them outside of Cape Cod and across. Massilchusetts Bay, lut also aromel to the sheltered cove at the point where Cape Ann joins the mainland at the north. If we complare the exceptional case of Goose cove in the morth with Ciay Heat and Montauk in the south, it seems to be the rule that wherever the water is cold enough, we meet arctie species, and wherever it is warm enough we have Long Island species, rogardless of the remotemess of localities where the species naturally aboumb, amb as fin as we know, of the alsence of enrents to transport the spores.

Onr matrine florat is marked by the complete absence of any members of the onler Dietyetacer. Maliseris polypodiodes has been foumd on the coast of Xorth Carolina and, at Charleston, P'adina paromia begins to become common, but north of Jorfolk not a single sjereies of the orrler is known, the northern species referreal by Harrey in the Pereis to the

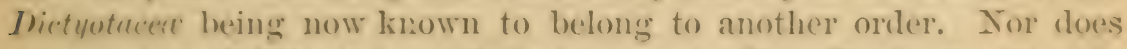
any spereses of Tilopteris or Cutleria ocem in New England. The al)sence of sotale of the common European genera of Florided is also worthy of notioe. The genus Nitopleyllum is entirely wanting north of Forth Carolinat, and, although a species is said to have beconcollexeterl off Cape Fear, and although $\mathbf{X}$. ocellutum is oceasionally fommel at Key Wext, this genus, which forms one of the more striking feattures of the Europeatn flora, may be said to be practically almost unknown anywhere on our Atlantic coast. Bomemaisonia asparagendes, which oceurs as far north as Norway, although rare, may perhapes hes fomml with us. Sospecies of Sehizymenie or the relaterl genera is fommel with us although the western coast is perhalps too rich in species of this perplexing group. Plocamium coccineum, one of the commonest red sea-weeds not only of Europe but of our west coast, is known with us in only one doubtful case. Gelidium corneum, which is abumbant in almost all parts of the world, is only occasionally found in New Englamel, and then only in the reduced form, separated by some as a distinct species, under the name of $G$. crinale. It may here be remarked that it is often a difhicult matter to determine whether some of the more beatutiful seatweerls of Europe really oceur with us or not. Our amateur collectors have frepuently exchanged with Emoprean collectors, and one not unfrequently sees spereinens of Plocumium coccineum, Cullophyll is lariniutu and other Emopean species prized for their beauty, which are satid to have been collected on our own coast. Liut inasmuch as no carreful collector has fomml the speeres in question, I haveconsirlered it tonomsatie to accept the statements of amatems who, to my limomlerlge, hatre re ceived specimens from Europe, and who, in gronemal, are not ateurate as to dates and localities. The preceding remarli will not, however, alplyly to the species of Fucus and the coarser sea-weeds. Fucus serratus, very 
common in Europe, is very rare with us, haring been found in but one locality in the United States and one in Nova Scotia. Fucus canaliculatus, II imanthalia lorea, and the common European Cystoseirce are quite wanting. The nearly ubiquitous Codium tomentosum is a species which has not yet been found on our northern coast. On the other hand some species, as Spyridia filamentosa and Chordaria divaricata, are more abundant in New England than in Europe, and the same is probably true of Euthora cristata and Ptilota serrata, if we except perhaps the arctic zone.

It is evident that a great deal remains to be done before we can say that we have as accurate a knowledge of our marine flora as we have of that of most European countries. Hereafter any ad vance in the knowledge of our marine algre must be made by a careful microscopic study on the shore. Probably all tie large and striking species are now known, or if any remain to be discorered their discorery will be by mere chance, and not by any systematie search. That is especially needed is information about our winter and spring forms, and this can be best obtained by persons who either live on the shore or spend several months there, so as to be able to take advantage of the comparatively few days for collecting, which occur in our severe winters. The habits and structure of our. Laminarix need careful examination, microscopic as well as in the gross. The whole order of the Plicesporece, in fact, which abound in spring, should be studied, especially the genus Ectocarpus and its allies. Our Cladophorce are in great confusion, and in the present paper I have been able to contribute Dut little towards their proper arrangement. Sereral years of study are necessary for the purpose, and, in fact, the task cannot well be accomplished until the European species are better linown. Our Clece are not in much better condition. The Clvce proper, thanks to the elaborate account of the genus given in Le Jolis's Liste des Algues Marines de Cherbourg, can be tolerably well made out; but the determination of some of the species of Monostroma is merely approximate. The Cryptophycece, which inhabit the shores and brackish localities, are very numerous, and a large number of forms probably remain to be discovered. A study of the last-named order is, moreorer, not without a practical bearing, as is shomn in another part of the report, by the fact that the canse of the so-called red fish is due to the growth of an alga of this order. It is probable that we have with us nearly all the European species of this order, and an excellent guide for our students, is the admirable paper by Warming on the Bacteria of the Danish Coast.*

Another gronp requiring study is the Squamariea, a small order consisting of species, which form crusts on stones and shells, often in (leep water. As a rule comparatively little in the may of sea-treeds is found by rledging; l, ut an eximination of shelly and gravelly bottoms for Stquamarice is to be desired. Dredging is most successful betreen 10

* Om nogle verl Daumarks Kirster levende Bakterier, in Videns. Med. Natur. Foreu., Copenhagen, 1875. 
and so fithoms, and at a greater depth than 50 fithoms almost nothing is fouml. The oyster-beds of the coast should be carefully searehed for Cutleriea and other sea-weeds found in similar localities in Europe. Fi. nally, a thorough exploration of the tidal rivers and sheltered coves of the eastern coast of New England is much to be desired, in order that we may know to what extent the southern forms extend northwa:l when they find sufficiently warm water and a suitable place of growth.

From an economical point of view, but little need be saicl with regart to our sea-weeds as an article of food. Chondrus crispus, the Irish moss. an it is called in this country, is the only species of ant commercial ralue. It is collected in considerable quantities at several localities, but espe. cially at Ilingham, Mass. It is used for making seat-moss farine, and is also employed to some extent by brewers for clarifying beer. As yet the use of Porphyra rulgaris, the laver, one of the common species for making soups, has not been introduced. The Chinese employerl in the shoe fitetories at North Adams, Mass., import the same speceies from China, not apparently knowing that they could obtain an abunlance of it in Massadehusetts. The dulse, Rhodymenia palmata, is sold to some extent in the seaport towns, especially in Boston, where it is eaten principally by sailors and the Irish population. It is generally imported from the British provirces, but it could be obtained in abundance anywhere north of I boston, or eren in some places in Long Island Somel. The great use of onr sea-weeds is for the purpose of making fertilizers, and immense quantities are carted from the beaches and spread over the land near the shore. Usage, however, raries at different lochlities, for at Lastport the larger sea-weenls, which are praretically the same species that are highly esteemed in Xew Iampshire and Massachusetts, are considered of little value in comparison with animal manure. As far as I know, there are no manufactories of iodine or sodla salts on our coast, althongh our species greatly. resemble those used in seotland for the purpose. The stem of the devil's aprons, Laminaria, are used by surgical-instrument makers in the manufacture of sponge-tents.

Respectfully submitted.

CAmBRIDGe, January 1, 1880.

\section{G. FATLOW.}

\section{STRTCTLRE ANI CL.ASSIFIC.ITIOY OF SE.IVEEDS.}

With a very fiew exceptions, all the plants of our coast which may be satid really to grow in the water belong to the division of the regretable kingdom known as the Cryptogains, or plants having no true flowers or sceds. Only two species of llowering plants are commonly found sub. merged in salt water, viz, Zostera marina, the salt-water eel-grass, and Iinppia marisian. The former is familiar to every one who has ever been to the shore, and is sometimes washed ashore in immense quanti- 
ties. The latter is a common species of brackish bays and cores. If we add Zannichellia palustris, a species closely related to Ruppia, and a few species of Potamogeton, which occasionally make their way into brackish-water ditches and streams, we hare completed the list of flowering plints which the student of marine regetation is likely to meet on our coast. Excepting the few tlowering plants just named, and a iew Characeer, an order whose place is doubtful but which is now generally placed near the mosses, which probably inhabit our brackish waters, our marine Hora consists wholly of Thallophytes, the lowest division of the Cryptogams, the species of which are supposed to be destitute of any true axis and leares such as are found in the higher plants. The Thallophytes have been divided into three classes, Alga', Fungi, and Lichens. This classifiation, as we shall see, is based on physiological rather than on morphological grounds, and is vere far from being satisfactors; but, although new classitications have been proposed, which, in time, will almost certainly supersede the old, at present it is impossible to ignore the old divisions, which may be said rather to be conrenient than to be based on accurate knowledge of structure and derelopment.

Of the three old groups, the Alge may be described as Thallophytes which grow submerged in water or in wet places, which contain chlorophyl, or leaf-green, and which are able to transform inorganic into orsanic inaterial, or, in other words, to support themselves from the inorganic matter about them. The Fungi do not grow submerged, do not contain chlorophyl, and are mable to change inorganic into organie matter, and hence must live as parasites upon bodies which contain organized matter. The Lichens were supposed by the older writers to be distinct from alge and fungi, and characterized by having in their interior certain green bodies known as gonidia. It is to the first of the three divisions named, the alge, that, with rery few exceptions, all the strictly marine plants belong. How unscientitic the division into algre, fungi, and lichens is may be seen by the fact that on our coast there is one species of fungus which grows submerged in salt water, an undescribed species of Sphoria, which is parasitic on the stems of the large deril's apron, Laminaria longicuris. A few species of lichens grow between tide-marks, and sereral in places exposed to the sprar. Terrucuria mucosa T. Fr. is abundant on our northern coast, and might be mistaken by a collector for Isactis plana. Terrucaria maura $\mathrm{T}$. Fr., and one or two other Terrucarice, are rather common near ligh-tide mark, but are not generally submerged. Practically speaking, then, when we speak of our sea-weeds we refer merely to the algre, which constitute ninety-nine one-hundredths of the flora.

ILarrey, in his Xereis, dirided algx into three classes, Melanospermece, Rhodospermere, and Chlorospermere. These three classes are distinguished by their color, the first being olive-brown, the second red or purple, the third green. This classitication, which answered tolerably well for distinguishing the species at sight rests, upon what modern researches 
have shown to be erroneous views with regarl to the structure and de. velopment of the different species, and harvey's three classes no longer serve as a hasis for classification. The Melenospermece and Chlerospermed are entirely rearranged, and although the Rhodospermed are still consiclereel to form a natural group, the older name, Floridere, employed by Agarelh, is used to designate them. The hatsis of classification is the structure of the frut and the organs of fructification. in the knowledge of which at great advance hats been male during the last twenty gears.

Caviropirion:-The lowest of all the algat are those which belong to

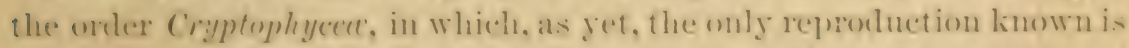
ly means of non-sexual spores and hormogonit. Ifost of the species of the oriter are bluish green, but some are purplish, hrown, or even pink. The bluis! green coloring matter is due to the presence of pliyeochrome. which is a mixture of chlorophyl and phyeocyanin. The list is extracte? by water when the algae containing it are loruised, the chlomopleyl being soluble in alcohol. The spreeies of Cryptophycere consist of cells which are ustally roundish, or disk-shaped, and which are generally hehl together ly a mass of gelatinous substance which surrounds them. The order is dirided into two suborders, aceorling to the arrangement of the cerls in relation to the jelly. The first suborder, the Chroococecece, inclutes all the species in which the cells are either isolated or arranged in amor. phons or more or less spherical masses. Some of the species of this suboraler are very small, and in some of the modern classifications are placed with the bucteria, in the order Protophytes. The mode of growth of the Chroococencere is ly division of the cells, first into two, then into four, and so on. The masises which they form may be called coloniers. each cell forming a distinct individnal, which is usually capalole of living apart from its fellows. Spores, which are known in only one species, are formed by some of the cells enlarging and taking on a thick cell-wall. Xothing like sexual repoduction is seen either in this or the next sul. order.

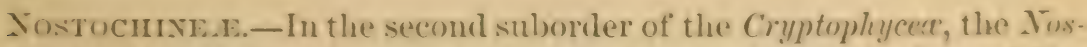
tocined, the cells are always attached to one another in the form of tilit. ments, to which the name of trichomate is given. The trichomata may either le free, as in Oscillaria (Pl. I, tig. 5), inclused in a sheath, as in Lynglyya (Pl. I, fic. 4), or packed in a dense mass of jelly, as in litrularia (Pl. II, fig. 2). The cells (composing the trichomata are ustally disk-shaped or eylintrical, but are sometimes nearly spherical.

besides the ordinary cells, we find in many species a second linel of eell, distinguished from the oihers by its glatsy appearance and its jellowish or brownish rather than bluish.green color. (II. I, fig. 3, a: fig. 6, b; Pl. II, figs. 1 and 2, a.) They are called heterocysts, and are found sometimes seattered amongst the of her cells, and sometimes at the end of the trichomata, their position often serving as a generie character. The reproduction of the Iostochinece talies place in two ways, hy hormo- 
gonia and by spores. Both modes, howerer, are entirels of a non-sexual character. In the genera with numerous heterocrsts, as Nostoc, the hormogonia are formed as follows: The cells intermediate between two heterocysts escape in the form of a small chain, called a hormogonium, and swim about with a spiral motion through the water. They at length become quiescent and begin to diride both transrersely and longitudinally. Of the cells thus formed some become heterocysts, and in process of time anew Nostoc is formed. In the species destitute of heterocests, or in which the leterocysts are few in number, the hormogonia are formed in a different manner. At certain points in the sheath of the trichoma constrictions are formed, and the cells between the constriction adhere to one another to form a hormogonium. Te thus have formed a necklace of hormogonia, which are capable of moving upwards and downwards in the sheath until finally it is ruptured and the hormogon ia make their escape. When free they are capable of moring about to a slight degree in the water, and erentually come to rest, and new heterocysts and trichomata are then formed by cell division.

The so-called spores of the Nostochinece are formed by the enlargement of some of the ordinary cells to several times their original length until they become oroid or cylindrical (Pl.I, fig. $3, \downarrow)$. They are found in a number of genera but in a number of others they have not yet been observed. They usually occups a fixed position with regard to the heterocyst, so that they are used as a generic mark. When ripe they hare a dense outer corering and become at times quite dark colored. Thes are more resistant than the ordinary cells and do not usually germinate until after a period of rest. In germination, which has only been obserred in a fer instances, the outer wall of the spore bursts open and the contents grom out in the form of a filament, in which by transverse division the ordinary cells are formed.

The Cryptophycece are alga which flourish only in summer, but which can be found to some extent at all seasons. Most of them form slimy expansions on mud, wharres, stones, and on dead algæ. They are not often found submerged at any depth, but are most abundant near highwater mark. A few filamentous species attain a length of some inches but only one, Lyngbya majuscula, is sufficiently striking to hare gained a popular name-mermaid's hair. The species of Oscillaria, Spirulina, and Beggiatoa, are capable of oscillating rapidly, but in this respect the marine species are not so well marked as the species of fresh water. The Beggiatoce which are found on putrefying algæ give off the disagreeable odor of sulphuretted hydrogen often noticed at the sea-shore in hot weather. The species of Cryptophycece are very widely diffused, and, with two exceptions, our forms are all common in Europe.

ZOOSPOREA-This order includes not only the greater part of the Chlorospermece of Harrey's Nereis, with the exception of the Oscillatoriacere, which belong to the Cryptophycece, but also the Laminariacee and all the Dictyotacee which Harrey attributes to the New England coast. Al- 
though the species included in this large order differ from one another in size and habit to an extent that would certainly forbid their being placed together, if we considered merely the character of the frond, yet they resemble one another very closely in their mode of reproduction, which is acemplished by means of zoospores. 'The Zoosporce are dirided into four suborders, the Chlorosporee, or C'hlorozoosporec, as the name is sometimes written, the Phasosporea, or Phaozosporea, the Bryopsidea, and the Botrydieve. The former are abundant in both fresh and salt water. They especially frequent brackish waters and high tide-pools. The mass of the regetation in brackish rivers is formed of species of this order. The species are either filamentous or else in the form of green membranes, as in the seallettuces, $C 7$ re, which abound in muddy places between tide-marks. The contents of any of the cells may be transformed into zoospores, which eseape from the mother cell usually at daybreak. The zoospores are of two kinds, microzoospores and macrozoospores. The latter are produced few in number in the mother cell, and when they have escaped into the water they are seen to be furnished with four cilia placed at one end, and with a dark red spot on one side. After swimming about for a short time they come to rest, the cilia disappear, a wall of cellulose is formed around the zoospore, which then begins to divide and produce it plant like that from which it eame. The microzoospores are borne in considerable numbers in the mother cell, and when they escape they are seen to have only two cilia at one end, and a dark red spot on the side. The microzoospores, after swimming about a short time, approach one another in pairs, occasionally in threes, which in a short time coalesce so as to form a body known as the zygospore, or, to use a term first applied ly Rostafinski, the isospore, which has four cilia and two dark reel spots. The zygospore swims about for a short time, then comes to rest, takes on a cellulose wall, and begins to divide in the same mamer as a macrospore. This process of union is called conjugation, and represents sexuality in its lowest form, it being impossible to say which of the conjugating bodies is male and which is female. It is only the microzoospores which come from different mother-cells which eonjugate, but it is not quite certain whether the cells must belong to different individuals. The microzoospores, howerer, do not always conjugate. More frequently they do not, but, after swimming about separately for a short time, lose their cilia and begin to grow just like the macrozoospores. If one wishes to examine the zoospores, he has only at erening to put a piece of sealettuce into a ressel of salt water, and at daybreak the zoospores will have formed a green cloul in the water. If the cloud consists of microzoospores, it will collect in the ressel on the side nearest the light; if composed of macrozoospores, on the side away from the light. Conjugation was first observed in a marine species ( $\mathrm{C} l \mathrm{k} a$ ) by Areschoug, but had previously been observed by Pringsheim in a fresh-water species (Pandurinu). Since then conjugation of zoospores has been studicd by sereral observers. 
BryopsIDE E.-In the present paper this suborder includes a single species of our coast, Bryopsis plumosa, which consist of a single cell of very large size, which branches in a pinnate fashion. When about to reproduce, some of the branches are shut off from the rest of the frond by a cell-wall, and the contents are then transformed into zoospores. A conjugation las not yet been seen in this species. From its unicellular structure one might suppose that Bryopsis should be placed near Vaucheria, but no oospores have yet been obserred like those in the lastnamed genus. In the absence of a knowledge of the development of the genus, it is retained as a divsion of the Zoosporex, differing from the Chlorosporece in the unicellular character of the frond.

BOTRYDIE E.-The derelopment of Botrydium granulatum, which was fully studied by Rostafinski and Woronin, differs from that of the Chlorosporece which we have already described in the fact that there is first produced in the small unicellular frond of which this species is composed a number of round spores, or more properly zoosporangia, which are discharged from the mother cell. There is then formed in each zoosporangium a number of zoospores, which escape and conjugate with one another. De Bary and Strasburger have described a similar process in Acetabularia mediterranea, and have applied the name gameten to the zoospores which conjugate, and zygote to the body formed by conjugation. Secondary modes of reproduction by means of zoospores with a single cilium and so-called root-cells occur in Botrydium granulatum. Botrydium (Codiolum) gregarium, our only marine species, resembles $B$. granulatum, but its development has never been fully studied.

РнÆOSPORE A.-The Phocosporec are all marine, with one possible exception, and are, when growing, of an olive-brown color. They possess only one form of zoospore, which is more or less oval and pointed at one end and olive-brown in color, and are furnished with two cilia attached at one side and a red spot. The zoospores are not born indefinitely in any cell, but are produced only in certain cells or sporangia. Each species is supposed to have two kinds of sporangia : one called the unilocular sporangium, which contains a large number of zoospores, and another, called the plurilocular sporangium, which consist of an aggregation of small cells, each of which contains a single zoospore. The name of oosporangia was originally given by Thuret to the unilocular sporangia because they are usually more or less oval in shape, but he afterwards abandoned the name because it is more appropriately applied to the spores of the Oosporece. The older name of trichosporangia, which was at first applied to the plurilocular sporangia, has also been abandoned. Although, as has been said, each species is supposed to have both kinds of sporangia, in a large number of species only one kind has as yet been observed. Both may occur on the same individual and at the same time, but more frequently they are found at different seasons of the year. Although found all over the world, the Phoosporex particularly affect the temperate and arctic regions, and they fruit more abundantly, as a rule, in winter 
and spring than at other seasons, if we except a few genera, like Ectocarpus. The conjugation in this suborler was first seen by Areschong in Dectyesiphen, and afterwards by Goebel in Ectocarpus pusillus. The zoospores unite in nearly the same way as in the Chlorosporet. Aceorl. ing to fiocher, who studied the zoospores eming from plurilocular sporamgia, the conjugation oceurs between zoospores coming from different sporangial. The development of the zygospore and the action of the zoospores borne in the unilocular sporangia, except in the genus Ihetyosiphom, are not yet satisfactorily known. Thuret and Bormet have soen borlies which they consider to be anthericlia in several species of Ectoearpus, and Pringsheim at one time considered that he had fomd antheridia in a species of sphacelaria. It is now admitterl that the bodies foumd by l'ringsheim belonged to a parasitie species of ('hytridium, and Thuret and Bornet were unable to aseertain the development of the antheridia in Ectocurpus. At any rate, nothing like an oogonimm or any female organ to be fertilized by the antherozoids has been found in the I'licesporece.

Is has alrealy been hinted, the genera of Pharosporece differ from one another very widely in the structure of the frond. From low forms, consisting of short filaments, we pass upwarts, through rarious eylindrical, erustaceous, and globose forms, to the highly developed devil's aprons, Laminurece, the largest of our sea-reeds; and, finally, on the coast of California and in the Antaretic Ocean, we find the perfertion of the order in the enormons Macrocystis pyrifera, which is sereral humbred feet long; the Nereocystis or bladder-kelp of California; and Eyregin, in which we have what appears to be a separate stem. leares, bladders, and fruit-bearing leares. Janezerski distinguishes three principal modes of growth of the thallus in Pherosporcer. The first consist in growth from a single terminal cell, as in sphacelaria, Cladostephus. and Dictyosiphon, resulting in the formation of a filamentous solid plant. The second morle consists in the simultaneous growth of several contignous filaments at their tips, so as to form either a flat expansion, as in Myrionema and Ralfsia, or a more or less globular bodly, as in Leuthesin. The third mode is illustrated by the genus Laminaria, in which there is a stalk, a blade, and root-like growths. The place of growth is at the point of union of stem and blade, and the new blade, which begins to form at the tip of the stem, grows upwards from the hase and gradually pushes off the old blade. In Srytosiphom a similar mode of growth is found only here, there being no stalk, the growth is at the base of the plant. Juring a certain part of the year, especially in the spring, most of the P'hensporece are covered with delicate hairs, which disaplear as the plant becomes old.

The suborder contains a lirge number of speeces, which are divided into several families. Those foumd on our eoast are the following:

SerTosmonoxe.-This family inclutes the two genera seytosiphon and Phyllitis, which comprise the old Chomda lomentaria and Laminaria 
fascia, which rere placed among the Laminarice in the Nereis Am.-Bor. In Phyllitis the frond is membranous, and its whole surface is covered by the plurilocular sporangia which are formed from the superficial cells, which divide so as to form clul)-shaped filaments consisting of five or six cells, each one of which contains a zoospore. Scytosiphon resembles Pliyllitis except that the frond, instead of being a flat membrane, is a hollow tube. There are no paraphyses in Phyllitis, but in Scytosiphon there are oroidal cells interspersed among the plurilocular sporangia, which seem to be of the nature of paraphyses. No true unilocular sporangia are known in this family.

Punctarie a. - In this family we find both unilocular and plurilocular sporangia, which are formed in spots on the frond, and arise from the superficial cells. The former are spherical and the latter ellipsoid in outline, and divided into a number of small cells.

Desularestie z. - In the two preceding families the fronds were either flat membranes or hollow tubes. In the present there is a solid axis and numerous branches. The cells of the cortical layer are changed into unilocular sporangia. The plurilocular sporangia are unknown.

DictrosipHove E.-In this family the fronds are solid and branching as in the last, and only the unilocular sporangia are known. They are in the form of large spherical cells, imbedded in the cortical layer and opening at the surface. Except that in Desmarestia the sporangia are formed directly from the superficial cells, while in Dictyosiphon they originate below the surface, this tribe scarcely differs from the last.

ECTOCARPE AE.-This family comprises a large number of filamentous algæ, upon whose branches are borne the sporangia. The plurilocular sporangia are usually in the form of pod-like branches, composed of a large number of small muriform cells, in each one of which is produced a zoospore. The unilocular sporangia are either globose bodies, borne on a short stalk, or else are formed by the direct enlargement of sereral contiguous cells of the branches.

SPIIACELARIE A.-This family is kept distinct from the last by Thuret. Both unilocular and plurilocular sporangia are known, and are similar to those of the Ectocarpece. If the two families are to be kept distinct, the reason must be that the fronds of the present order are solid, and the growth is by the means of a single terminal cell, which is not the case in the Ectocarpece.

Leathesie A.-In the Leathesiece and Chordariece the sporangia are distributed indefinitely orer the frond, but in the succeeding families they are found in separate spots or bands. The Leathesiea, in which we do not include Mryrionema, are either in the form of small tufts, as in Elachistea, in gelatinous expansions of indefinite shape, as in Petrospongium, or in resicular masses, as in Leathesia. The greater part of the frond consists of a cellular filamentous mass, upon the surface of which is borne a layer of short filaments composed of smaller cells. 'The uni- 
locular and plurilocular sporangia are borne at the base of the peripheral filaments. In Elachisten there are also paraphyses.

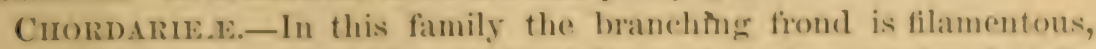
and eonsists of an axis of longitudinal filaments and a peripheral series of short filaments, which are griven off at right angles to the axis. Tho sporangia are found amongst the peripheral filaments, the unilocular aro oroidal, and the plurilocular arise from the metamorphosis of the cells at the outer extremity of the peripheral filaments.

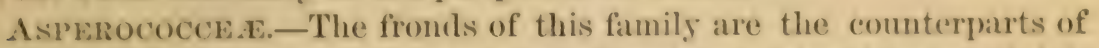
those in the seytosiphonee, but the sporangra, instead of being superficial, are external and do not cover the whole surfice, hut are found in spots. The spots contain paraphyses and spherical unilocular sporangia.

RALFsIF. - In this family, composed of very few species, the fromd is in the form of a crust, resembling a lichen. The fruit is found on the surface in spots, composed of paraphyses and unicellular sporangia.

SPOROCINEA.- Here the frond is a solid branching filament and the fruit is found in spots on the surface. Each spot consists of a number of paraphyses, at the base of which are either oval unilocular sporangia or plurilocular sporangia in the form of short filaments, resembling tho sporangia of Phyllitis.

LAUIXARIEA.-The family which includes the devil's aprons and seacolander of our coast. The fruit either forms long patches or more or less irregular spots along the center of the frond. Unicellular sporangia only are known. The sporangia are separated from one another by peculiar-shaped unicellular paraphyses, which are expancled at the top so as to cover the sporangia.

OOSPORE.E.-In the orler Zoosporce the sexual reproduction consists in the direct union of two zoospores, which form a zygospore. The two conjugating zoospores, or gameten if we adopt De Bary's nomenclature, are alike in structure, and it is impossible to say which is male and which is female. In the Cutleriece, of which no representative has as get been found on our coast, we have algae resembling the Phocosporece in habit, but differing from them in that their reproduction is of a higher grade. The Cutleria have both zoospores and antherozoids, or proper male organs. The zoospores are large, and are born singly in cells, which are united in eights into an oblong body. The antheridia borno on distinct individuals are also oblong in shape, but, instead of being divided into eight cells, they aro formed of a much larger number of small cells, in each one of which an antherozoid is produced. The antherozoids are small oval bodies, almost colorless, and provided with two lateral cilia. In Cutleria collaris Reinke found that the zoospores after swimming about for some time, lost their cilia and came to rest. While at rest the antherozoids approached them, and he considered that the sexual union then took place. Here, then, we fincl a clear clistinetion of the sexes such as is nowhere found in the Zoosporer, and it is but a step higher to the Oosporee, in which we have a distinct malo 
organ, the antherozoid, borne in an antheridium, and a female, called in this order the oogonuim. The order is divided into two suborders, in which, although the general plan of reproduction is the same, the details vary.

VAUCHERIEA.-This suborder includes a number of species of green algæ which form dense turfs upou the mud in brackish ditches and rivers, or else loosely floating masses of green filaments. They may generally be recognized at sight by their deep-green shining color and velvety appearance. Ther consist entirely of long green threads, which occasionally branch, but which are destitute of any cross-partitions except at the time of reproduction. The non-sexual reproduction is by means of zoospores. A cross-partition is formed near the end of a filament, and in the cell thus cut off from the rest of the plant a single very large zoospore is formed. In some species the zoospore escapes through an opening in the apex of the cell, and when free its whole surface is seen to be covered by a large number of vibratile cilia. In other species the cell containing the zoospore breaks off from the rest of the plant and the zoospore remains in a more or less passive condition. The antheridia grow from the sides of the filaments, and are either in the form of oblong, at times nearly sessile, cells, or else a lateral shoot is formed which ends in one or more convolute processes, at the tips of which a cell is cut off from the rest. The antherozoids are very small bodies with two cilia. The oogonia, or female organs, are generally situated near the antheridia, and are irregularly ovoid, with a blunt tip. The cell contents collect in a roundish mass at the center, called the oosphere, while at the tip of the oogonium is a mass of slimy substance. At the time of fertilization the antheridium opens and discharges the antherozoids and the tip of the oogonium opens to admit the antherozoids, which remain for a short time in the interior of the oogonium and then withdraw. The oogonium is theu closed and, the oosphere, which before fertilization was merely a mass of protoplasm, has now formed around it a wall of cellulose, and ripens, forming an oospore. The oospore finally escapes from the oogonium and germinates.

FUCACE A.-This suborder includes the rock-weeds, Fuci and Sargassum, of our coast, which constitute the bulk of the olive-brown sea-weeds found between tide-marks. The admirable paper of Thuret on the fertilization of Fucus leaves nothing to be desired on that subject, and his observations are now so widely known in this country that little need be said in this connection. In the two common rock-weeds of our coast, Fucus vesiculosus and $F$. nodosus, the two sexes are on distinct individuals. In $F$. evanescens and $F$. furcatus they are on the same individual. The Fuci fruit principally in winter and spring, but $F$. vesiculosus may be found in fruit throughout the year. In the last-named species, if we examine the swollen tips of the frond, we find certain granular bodies, which on section are seen to be sacks opening outwards. The sacks are called conceptacles. The male plant can generally be distinguished from the 
female by the brighter color of the tips which hear the conceptates. A section throngh the conceptacles of the male plant, as in Pl. IX, Fig. '-, shows a number of branching filaments which line the interior of the conceptacle. Attached to the filaments are oval bodies, the antheridia. The antheridia contain the antherozoids, which are ovate and provided with two cilia attached at the side. Esually abont day-hreak the antheridia discharge their antherozoids, which then swim about in the water until they reach the female plant. A section through the tip of a female plant shows a number of conceptacles similar in shape to those of the male plant. On the walls of the conceptacle there are paraphyses, and seattered among them are the oogonia, as shown in Pl. IX, Fig. 1. The oogonia are oval and seated on hroad short pedicels. In Fucus rexiculosus the contents of the oogonia diride into eight oospheres, which are at first angular, but afterwards become spherical. The oogonia become free from their attachments, and the wall, which is really double, ruptures, and the oospheres escape into the water. In this condition they are merely spheres of protoplasm. The antheridia then collect around the oospheres in large numbers, and the mass begins to rotate. The rotation continues for a short time, and when it ceases the antherozoids withdraw and soon perish. It is not yet certain whether one or more of the antherozoids really penetrates into the substance of the oosphere during the rerolutions. As soon as it comes to rest the oosphere takes on a cell-wall of cellulose and becomes an oospore, which after an interval of rest begins to divide so as to form eventually a new frond.

DiCTYOTE E.-Although no members of this order are known on our coast north of North Carolina, the order cannot pass unnoticed in the present article, because it forms a connecting link between the Fucaces and Phasosporece on one hand and the Floridece on the other. The species are olive-brown and form expanded membranous fronds. Three kinds of reproductive organs are known, antheridia, spores, and tetraspores. All are formed by outgrowths from the superficial cells. The tetraspores are formed, as the name implies, in fours in a mother cell, from which they escape and then readily germinate. The spores are borne singly in a mother cell. The antheridia are composed of a number of ohlong cells, which become divided by numerous longitudinal and transrerse divisions into small cells, each of which contains an antherozoid. The Dictyotace resentble the Floridece in haring tetraspores and spores which germinate without first passing through a zoosporie conditum. The action of the antherozoids is at present unknown, and the spmres of this order cannot be the product of a fertilization such as we find in the Floridec.

FLORIDE. E.-This order is the same as the Iihodospermene of Harrey's Sereis. The species eomposing it form a very natural group, and are, with the exception of a few genera, entirely marine. Their color is always some shade of red or purple when they are growing in their nor- 
mal condition. When, however, they grow in positions where they are much exposed to the light they become green, and in decaying they pass through various shades of orange and yellow to green. Their farorite place of growth is below low-water mark and in deeper water, but some species grow in tide-pools. The fronds vary in structure in the different genera, but as a rule they are less complicated than the fronds of the Fuci and Laminarier. The non-sexual morle of growth is by means of bodies called tetraspores, formed by the division of a single cell into four parts. The divisious may be at right angles to one another, when the tetraspore is said to be cruciate; they may be parallel to each other, in which case the tetraspore is said to be zonate; or they may be arranged as in Pl. XI, Fig. 1 , when it is said to be tripartite. The tetraspores may either be isolated or collected in wart-like masses, called nemathecia. The individuals which bear the tetraspores are, with rare exceptions, distinct from those which bear the sexual fruit or cystocarps. Occasionally both kinds are found on the same individual, as sometimes happens in Callithamnion Baileyi and Spyridia filamentosa. The tetrasporic plants, taking the order as a whole, are decidedly more abundant than those which bear the cystocarps. The sexual fruit, called the cystocarp, is formed by the action of antherozoids upon a structure called the trichogrne, which forms a part of the procarpe. The antherozoids are small colorless spheres, destitute of cilia. They are borne singly in cells, which are agglomerated in various forms, which differ in the different genera, but are usually either in the shape of short, dense tufts, or else are siliculose in outline. In Chondria the antheridia corer the surface of irregular disk-like branches, and in membranous genera they form spots on the surface.

The name of procarpe was given by Bornet and Thuret to the collection of different cells, of which the female organ is composed before fertilization. The procarpes are borne on the younger parts of the frond generally near the surface. The cells of which they are composed may be divided into two sets-those which take part in the act of fertilization and those from which the spores are formed. The former consists of the trichogyne, a long, slender, hyaline hair, at whose base is the trichophore. The latter set, called by Thuret and Bornet the carpogenic cell or system, varies in the different genera, and is in most cases too complicated to be explained in the present article. In the simplest genera, as in Nemalion and Butrachospermum, the antherozoids come in contact with the extremity of the trichogsne, where they remain fixed for a consiclerable time. The contents of the antherozoid, or antherozoidsfor more than one may be attached to the trichogyne-pass into the trichogyne, and, in consequence of this action, a change takes place in the trichophore, which divides, the divisions growing into short filaments, which are formed into chains of spores by transverse divisions. In this case the trichophore represents the carpogenic cell. In Nemalion the cystocarpic fruit is a globular mass of spores, arranged in filaments 
and destitute of any general envelope. In by far the greater number of genera the spores are not formed ly direct outgrowths from the trichophore. In Cullithamnion, for instance, the fertilizing influence is propragated from the trichogrne, throngh the trichophore and the cells below it which constitute the trichophoric apparatus, to certain lateral cells, from which by repeated cell-division the spores are formed. In Dudresnaya the. cells of the trichophorie apparatus send out a number of lateral tubes, which, in turn, convey the fertilizing impulse to certain modified branches in other parts of the frond, so that, in reality, the eystogarp is formed at some distance from the trichogrne by means of which it has heen indirectly fertilized. A similar mode of fertilization is known in Polyides and, according to Professor Schmitz, in the siquemariece. The cystocarps are sometimes naked, that is, without a special membranous envelope, as in Yemalion, but they not unfrequently are contained in a conceptacle or pericarp. In the latter case, the development can only be studied with diffieulty, because the conceptacle, which originates from some of the cells below the trichophore, develops more rapidly than the rest of the cystocarp, and so shuts out from view the process of the formation of the spores. It is impossible in the present article to enter into the details of the derelopment of the cystocarp in this complicated order, but the reader interested in the subject is referred to the superb work of Thuret and Bornet, Etudes I'hycologiques, and the hardly less admirable Notes Algologiques, of the same authors, for a masterly exposition of the subject.

\section{IIODE OF COLLECTING AND PREPARING SEA-WEEIS.}

The collector of sea-weeds should be provided with a pail of tin or wood, or, better still, with one of papier maché if it can be procured, in which he should place a number of large wide-mouthed bottles and several small bottles, and one or two vials filled with alcohol should not be forgotten. A knife is needed for scraping crustaceous algae from stones, and a geologist's hammer and chisel are often useful. A hand-net, with a long. stout, jointless pole and net with small meshes is a necessity. Clothes for wading are also indispensable, since the best collecting grounds are below low-water mark. If the collector is not already sufficiently encumbered, he may throw a common botanical collecting-box orer his shonlder, as it will serve to carry the coarser species. Collecting on sandy or gravelly beaches is very simple. One finds there only the Floridere and larger brown sea-weeds which are washed ashore after a storm. It is only necessary to pull over the heaps of refuse at highwater mark, or to dip up with a net the specimens which are floating at low-water. Collecting on beaches is uncertain, because it is only at certain times that specimens are washed ashore. On rocky shores, on wharres, aud on the eel-grass we are always sure to find something. One should examine the surface of rocks wet with the spray, the bases of the stalks of the marsh.grasses, and eren the surface of mud which is 
orerflowed at high tide. Here one will find an abundance of Cryptophycece and some Chlorosporew. Pools, more especially rocky pools, are rich in Chlorosporece and the filamentous Phcosporece. The richest locality is just beyond low-water mark, especially at the spring tides. One should carefully scrape old wharves and piers. This is best done at low tide from a boat. A long-handled net with a scraper on one side is the best thing, but any stout net will do. By scraping old moodwork which looks rery unpromising one sometimes gets the rarer Callithamnia and other delicate algæ. A number of interesting species are also to be found growing on eel-grass, which may be reached at low tide by wading, or, better still, by boat.

For botanical purposes the dredge is not of very great service. One sometimes secures by its means rare species, but, as a rule, a day of dredging is a day wasted. Most algæ grow on rocky bottoms where the dredge does not work well, in fact not so well as grappling hooks. The best opportunity for dredging is on a shelly bottom, where sereral rare species are found. Good specimens are not unfrequently brought up by fishermen on their nets. The different species when collected should be cleaned of sand and small animals and placed in bottles, each species in a separate bottle. This is absolutely necessary in case of genera like Cladophora and Ectocarpus, which would otherwise be hopelessly entangled. The small specimens and those to be kept for microscopic study should be put into alchohol. The coarse species which are merely to be mounted and are not to be studied should be put dry into the pail. Anything to be studied should be kept in plenty of water, or, if not to be studied in a short time, be put immediately into alcohol. It is, however, useless to put into alcohol large quantities of sterile specimens of genera, like Cladophora, the species of which are characterized by their branching and not by microscopic structure. Sea-weeds are best mounted in salt water, that is, in this way they are in a more natural condition for after-study, and if one is able to procure plenty of salt water it is best always to mount in it. However, one may be stopping at a distance from the shore, in which case it is possible to make use of fresh water. Besides, if salt water is used continually the driers become saturated with salt, and it is then impossible to prepare specimens in the damp weather so frequent at the sea-shore. As a matter of economy, one had better mount only the finer and most important specimens in salt water and the rest in fresh water.

The larger sea-weeds, as the rock-weeds and deril's aprons, should be allowed to soak several hours in fresh water before being mounted. They can then be pressed in the same way as flowering plants, and, when dried, mounted on the ordinary herbarium sheets. If a number of large specimens are to be prepared, it is best to hang the plants up as soon as they are gathered and allow them to dry, and they can afterwards be soaked out at leisure in fresh water. The collector should know that there are probably no plants which so quickly spoil driers as the species 
of roek-weed. For mounting the smaller speecies one should have two or three shatlow dishes of salt water, in which the plants are to bo washed and floated out, and a deep basin of either salt or fresh water, as the case may be, for mounting. A zine tank, one of whose sirles is slanting, is courenient for mounting, but is rather an awkward thing to carry about in travelling. The specimens to be mounted are put into the basin and floated out; a piece of paper is slipped under them and they are lifted out of the water. A molerately thick unglazed praper is hest for mounting, although almost any kind will do, provided it is not very thin. Many ladies make use of photographer's cards.

With a little pratctice it is perfectly easy to remove seatweeds from the water, hut to prevent the specimen slipping off the paper or to one side of the paper it is best to put the middle finger under the center of the paper and raise it so that the water drains off equally on all sides. Some slip a pane of gliss under the paper, and lift it out of the water in that way. The papers should then be left in an inclined position for a short time, so that the superthous water may run off. They are then to be put on the driers and eorered with a piece of muslin or other thin white cloth, from which the glazing has been removed by washing. Very gelatinous specimens should be exposed for some time to the air before pressing. The driers should be of bibulous paper and the best material, but unfortunately the most expensive, is thick white blotting paper. The specimens are to be laid on the paper and covered with a cloth, and then another layer of paper is placed above, and so on. The best form of press is a boarl with a number of stones for weights. The driers should be changed morning and night until the specimens are dry. Some of the smaller species dry in a few hours; others require two or three days. Great pressure is to be aroiden, and the specimens, if prepared in fresh water, should not be allowed to remain long in the water. Most small species athere to the papers naturally; others reguture to be fastened with gum. Besides mounting specimens on paper, it is a very good plan to prepare specimens of fruit or any small filamentous species on pieces of mica or glass. Fragments of mica good enough for the purpose can be obtained for a very small sum of those who manufacture air-tight stoves. Specimens prepared on mira can be moistened and at once used for microseopie study. All really microscopie forms, such as Glencapsa, Clathrocystis, \&ec., had hetter be mounted on mica or glass than on paper. A difliculty is experienced in preparing corallines and other calcareous forms. If prepared in the same way as other sea-weeds, they become very brittle, and are often ruined by transportation. Various means have been devised for making them less brittle-such as painting them with a thin solution of gum. $A$ better method is to paint them with a hot solution of isinglass which has been boiled for a few moments in alcohol. The halit may he preserved, although the structure is somewhat injured, by immersing coral- 
lines for a short time in some dilute acid, which, by removing the calcareous matter, renders the specimens more flexible.

As we have said, selected material for future study should be put into alcohol. Several other preserving fluids have been recommended, but none in the long run do as well as alcohol. Some species do well in glycerine, especially parasites like Streblonema and Bulbocoleon, which grow in the fronds of other species. A one per cent. solution of osmic acid is a favorite preserving fluid of some botanists. Certain sea-weeds, as the Phacosporece, can be mounted for the microscope in almost any of the ordinary mounting fluids, and keep very well. The Floridece, on the other hand, do not keep at all well, and after a few months the preparations begin to spoil. A saturated solution of calcic chloride, a mixture of glycerine and acetic acid, half and half, boiled and filtered, weak solutions of carbolic acid, or a one per cent. solution of osmic acid are all about equally good for mounting algæ. As we have said, Phocosporece generally do well and Floridece badly, but one sometimes has success even with the latter. 


\section{OIDERS AND SUBORDERS *}

$\mathrm{OF}$

MARINE 1 LGE OF NEIV ENGLAND.

ORder I. CRYPTOPHYCEA.

Suborder CIROOCOCCACE $\boldsymbol{X}$.

Nostochine.

Order II. ZOOSPOREA.

Suborder Chlonosporex.

BRYOPSIDEA.

BOTRYDIE.E.

Pheosporex.

Order III. OCSPOREAE.

Suborder VAUCHERIE .

FUCACEA.

ORDER IV. FLORIDEE.

Suborder PoRPHYREA.

Squamariez.

Nemaliex.

SPERMotilairiex.

Ceramiex.

SPYRIDIE E.

Cryptonemiex.

Dumontie

Gigartineze.

RHodyMENIEA.

SpongiocarpeE.

Gelidiex.

H TPNE.E.

Solieriex.

SPILAROCOCCOIDEA.

RHODOMELEE.

Corallinez.

-An artiticial key to the genera of New Englaud algate will he found at the end of this paper. 


\section{ORDER I. CRYPTOPHYCEE, Thuret.}

Algæ composed of cells which are either isolated or imbedded in mucus, so as to form colonies, or united in the form of filaments. Color usually bluish green, sometimes brown, purple, or pink. Reproduction by hormogonia or non-sexual spores. Sexual reproduction unknown.

We have retained the name given by Thuret, in Le Jolis's Liste des Algues Marines de Cherbourg, to the group of low algæ in which sexual reproduction is unknown. Our species belong to the Schizophyto of Cohn (Beitrïge zur Biologie der Pflanzen, Vol. I, p. 202), which also includes the minute forms commonly known as Bacteria. Most of the species here enumerated are bluish green, owing to the presence of phycochrome, and would be placed by some writers in the order Phycochromacea. Some are destitute of phycochrome and have been placed by different writers in the Chroococcacere and Palmellacea. Nregeli, in Die Niederen Pilze, is of the opinion that the Bacteria should not be classed with the Phycochromacere, as in the Schizophyter of Coln, but one cannot expect to make a satisfactory classification of forms in which no sexual reproduction has, as ret, been discovered. The Protophytes of Sachs's Text-Book include all the Schizophyto of Cohn, together with the Palmellacece and Saccharomycetes. From the nature of the plants themselves, none of the above classifications can be considered of decided scientific value, and, regarding the question of conrenience alone, we have adopted the name Cryptophyceo as expressing sufficiently well all the marine Protophytes of our coast, whether they contain phycochrome or not. The order is divided into two suborders, as follows:

a. Cells free, or united by a gelatinous intercellular substance into families which nerer form true filaments....... CHROOCOCCACEA.

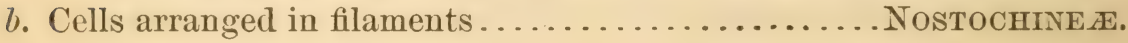

\section{Suborder CHROOCOCCACEÆ.}

(Gloogenœ, Cohn in part.)

1. Cells free or united in twos or fours ................ Chroococcus.

2. Cells united by a mucous intercellular substance into amorphous

[NotE.-In the following descriptive part of the present paper the synonymy of the species is carried only so far as to enable the reader, in the first place, to recognize the more common synonyms and also the works in which the synonymy is given in full, and, in the second place, to give a reference to the more accessible works in which the different species are figured. Of the latter frequent reference is made to the Nereis Boreali-Americana and Phycologia Brittanica of Harvey, to the Etudes Phycologiques and Notes Algologiques of Bornet and Thuret, and the Tabula Phycologica of Kuitzing. For a list of descriptive works consulted the reader is referred to the end of this paper.

All microscopic measurements are given in fractions of a millimeter, but gross measurements of objects more than half an inch in diameter are given in feet and inches, as the divisions of the meter are not, in this country, readily applied to objects which can be seen by the naked eye.

Unless otherwise stated, the loca lities given are those in which the writer himself has collected the species, but in the case of common species it has been considered unnecessary to give special localities. ] 
colonies. Intercellular substance generally forming concentric lajers around the cells ........................ Glococapsa. 3. Cells united in colonies of definite shape.

a. Cells arranged in the form of an irregular sphere, which becomes finally hollow and net-shaped . .............. Clathrocystis.

b. Colls arranged in several layers forming a solicl splheroidal body.

Polycystis.

c. Cells united in branching dendritic masses ........ Entophysalis.

\section{CHROOCOCCUS, Nirg.}

((From xpoos, the color of the bods, and коккоs, a berry.)

Cell dirision taking place in all directions, cells spherical, solitary, or united in twos or some multiple of two, free, i. e., not united into fimilies by means of an intercellular substance.

Accorting to Niegeli, the principal distinction between Chroococeus and Cilerocupse lies in the fact that in the former grenus the cell-wall is thin, while in the latter it is thick and formed of eoneentric layers. This difference, however, is not constant, as in (') roococius turgidus the cell-wall is comparatively thick, whereas in Cilerocapal erepidinum the cell-wall is reduced to a minimum. A more characteristie distinction secms rather to be the existence of an intercellular sulstance in Glaceapsa which binds the c.lls together, but which is wanting in Chroococcus.

C. Turaides, Nieg." (Protococcus, Kïitz., Tab. Phyce, Vol. I, Pl. 6, Fig. 1.-Hamatococcus linalis, IIassal, Fresh-water Algie, p. 331, Pl. s:- Fig. 2.)

Cells bluish green, oval, usually single or binate, about .02mu to 0.2.5m in diameter, surrounded by a thick cell-wall.

Cape Ann, Mrs. A. L. Daxis; Europe. Fresh water and marine.

Foumd on slimy rocks and piers upon which species of Calothrix, Lyngbya, d.e, are growing. Probably common throughout New England. The size of the cells varies wry much. What we have given above is an average measurement.

\section{GLEOCAPSA, (Kiitz.) Næg.}

(From yrosos, sticky, and $k \alpha \psi a$, a box.)

Cell division taling place in all directions, cclls spherical, with thick walls, solitary or united in fimilies, which are surrounded ly a gelatinous suhstance which is generally in concentric layers around the cells. Spores known only in (i.stegophila, Itzigs., (G. Itziggohnii, Bornet mser.).

This gremus, if we adept the views of the allrocates of Schwentener's theory, forms the gonidia of the lichen genera Synalissa, Omphalaria, \&c.

G. Crepidivis, Thuret, Notes Algologiques, p. 2, Pl. I, Figs. 1-3. (Protococens, Thuret, in Mém. Soc. Natur. Cherbourg, Vol. II, p. 388; Le Jolis, Liste des Algues Marines de Cherbourg, p. 2.5; Farlow, List 
of Marine Algæ, 1876.-Pleurococcus, Rab., Flora Europ. Alg., Sec. III, p. 25.) P1. I, Fig. 1.

Cells spheroidal, yellow, about $.0035^{\mathrm{mm}}$ to $.005^{\mathrm{mm}}$ in diameter, imbedded in an olive-brown gelatinous stratum, occasionally single, usualls united in twos or some multiple of four.

Eastport, Maine; Gloucester, Mass.; Newport, R. I.; northern coast of France.

We found this species abundant in October, 1875, on the wharves of Eastport, where it formed thin gelatinous layers of a dark-brown color at high-water mark. It probably occurs at high-water mark on wharves along our whole coast. This species is said by Thuret to form the gonidia of Verrucaria halodytes, Nyl., a species which we are informed by Prof. Tuckerman is not known to lichenologists in this country. In the present species the concentric lajers of the gelatinous envelope of the cells is wanting. The color of the cells is quite constantly brownish yellow, but occasionally they become dark green. The average diameter of the cells in American specimens seems to be slightly less than Thuret's measurement.

POLYCYSTIS, Kütz.

(From $\pi \alpha \lambda v \varsigma$, many, and $\kappa v \sigma \tau \iota \varsigma$, a bladder.)

Cells spherical, densely aggregated, united by an intercellular mucus into solid masses.

In this genus we include Microcystis of Kuitzing, in which the colonies are isolated and not united in botryoidal masses, one being evidently an immature state of the other.

P. Elabens, Kuitz. (Microcystis, Kïtz., Tab. Phyc., Vol. I, Pl. 8, Fig. 1.)

Cells bluish green, oblong, about $.004^{\mathrm{nm}}$ in diameter, closely packed in solid colonies, which are aggregated in botryoidal masses.

Wood's Holl, Mass.; Europe.

Common in summer on decaying algæ, over which it forms slimy masses, mixed with species of Lyngbya, Microcoleus, \&c.

P. PALLIDA, (Kütz.).

Cells bluish green, oval, .005-7 ${ }^{\mathrm{mm}} \times .007-9^{\mathrm{mm}}$.

Newport, R. I.; Gloucester, Mass.; Europe. On Cladophorce and Zostera.

Differs mainly in the size of the cells from the preceding species. Our form agrees closely with European specimens.

\section{CLATHROCYSTIS, Henfrey.}

(From $\kappa \lambda \eta \vartheta \rho o v$, a lattice, and $\kappa v \sigma \tau \iota s$, a bladder.)

Cells minute, rery numerous, imbedded in mucus, forming a colony which is at first solid, then hollow, and finally perforate.

C. roseo-Persicina, Cohn, in Beiträge zur Biologie, Vol. I, Part III, 
P. 157, Pl. VI, Figs. 1-10. (Mierohaloa rosea, Kiitz., in Linnea, VIII, 341.-Prowececus, Kiitz., Spee. Alg.-Pleurococens roseo-persicinus, Rab., Flora Europ. Alg._C'ryptococeus roseus, Kiit\%., Plıye. Genn.; Le Jolis, Liste des Algues Marines; Crouan, Florule du Finistere; Farlow, List of Marine Algae, 1s76.-Bacterium rubescens, Lankaster, in Quart. Journ. Micros. Science, Vol. XII, new series, p. 40s, Pl. 22 and 23.)

Cells very small, about .002.5 mm in diameter, rose-colored.

Whole New England coast; Europe. Both marine and in fresh water.

Firy common on decaying algie aud on the murl, which it corers with a purplish-red filu. It is also fouml on codfish in the (iloncester market, causing what is known as the red fish. This alga, of which the detailed history is given by Coln and Lankaster, 1. c., after having been placed by different writers in several different genera, has finally been associated with Clathrocystis cruginosa, Henfrey, a common fresh-water aliga of Europe and the United States. Both species are at first minute and solid, lut as they grow older become hollow, and at length portions become detached, learing lwoles in the circumference. Althongh in Europe the species is foumd in fresh water as well as in salt, it has not yet been observed in the interior of this country.

\section{ENTOPHYSALIS, Kütz.}

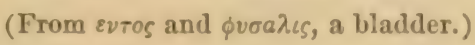

Cells united in colonies, which assume a dendritic form.

The genus is founded on Entophysalis granulosa, a species of the Mediterranean, referred by Zanardini to the I'almellacea, but more correctly by Thuret and Bornet to the Chroococcaceæ.

\section{E. Magiolie, n. sp.}

Cells dark purple, .001-6 ${ }^{\mathrm{mm}}$ in diameter, united in twos and fours and imbedded in jelly, which forms a densely branching mass.

\section{Magnolia Cove, Gloucester, Mass. Rare. Autumn.}

This alga forms a thin slime on exposed rocks, in company with Gluocapsa crepidinum. The ramifications of the frond are visible on careful dissection. The species is much smaller and differs in color from $E$. granulosa of Europe. The cells do not differ much in size from those of the Glococapsa, but they are of an entirely different color and have the concentric arrangement of the cell-wall much better marked than in that species. The cells adhere together in twos, fours, or somo multiple of four, and all are lyeld together ly a mucous mass, which branches in a rery dense fashion. Tho genus Entophysalis is merely a cilaccusen, which insteal of being indefinitely expanded is densely ramified.

\section{Suborder NOSTOCHINEA.}

(Nematogena, Coln in part.)

We have followed Thuret's Essai de Classification des Nostochinées, Ann. des Sciences, 6 série, Tome $\mathrm{I}$, in the arrangement of the genera.

1. Filaments terminating in a hyaline hair................ 7 Filaments destitute of a terminal hair................... 
2. Filaments furnished with heterocysts ..................... Filaments destitute of heterocysts.................... 3

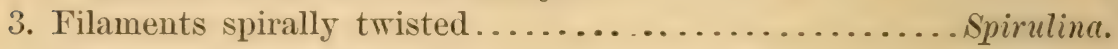
Filaments not twisted........................... 4

4. Filaments without a distinct sheath $\ldots \ldots \ldots \ldots \ldots \ldots \ldots \ldots \ldots$ Filaments formed of one or more colored trichomata contained in a transparent sheath.......................... 6

5. Cells bluish green or purple.................... Oscillaria. Cells colorless, or filled with minute black grains........Beggiatoa.

6. Sheath containing sereral trichomata............... Microcoleus. Sheath containing only one trichoma................. Lyngbya.

7. Filaments free, forming tufts of indefinite extent........ Calothrix. Filaments united by a more or less firm gelatinous substance, frond of definite shape and extent................... 8

8. Heterocysts basal, $i$. e., placed at the base of the principal filaments and branches.................................. 9

Heterocysts intercalary........................ Hormactis.

9. Frond hemispherical or resiculose, filaments radiating from the

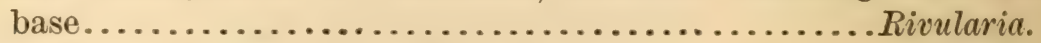
Frond plane, filaments paraliel..................... Isactis. 10. Filaments destitute of a sheath................ Sphcerozyga. Filaments consisting of a trichoma in a sheath......... Nodularia.

\section{SPHAROZYGA, Ag.}

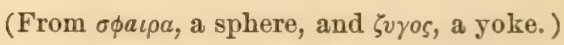

Filaments free, destitute of sheath. Spores produced in the cells adjacent to the heterocysts.

S. Carmichaeli, Harv., Phyc. Brit., Pl. 113 a. (Cylindrospermum, Kuitz., Spec. Alg., p. 294.-Anabaina marina, Bréb.). Pl. I, Fig. 3.

Filaments flexuous, densely interlaced, forming slimy bluish-green expansions, cells cylindro-spherical, about $.0035^{\mathrm{mm}}$ in diameter, diminishing in size towards the end of the filament, terminal cell pointed. Heterocysts sereral in each filament. Spores oblong, usually one on each side of heterocyst, about $.018^{\mathrm{mm}}$ in length when ripe, rather more than twice as long as broad, at first green, then jellowish.

Noank, Conn.; Wood's Holl, Gloucester, Cambridge, Mrass.; Europe. Summer.

Probably a common alga along our whole coast in midsummer and autumn on decaying algæ, looking like a shining emerald-green film. It occurs most frequently on the surface, but is also found at the depth of several feet. In his work on the Fresh-water Algae of America, Prof. H. C. Wood, jr., mentions the present species as occurring at Camden, N. J. We cannot, however, agree with him in placing it in 
the genns Dolehespermum of Thwaites. Ralfs, in Annals and Mag. of Nat. Mistory,

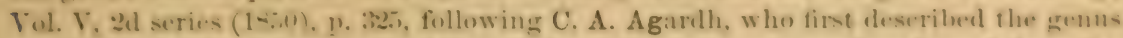
Spherezyga (Flora, 1-27), says that in Spharozyga the spores are first formed from the cells nearest the vesicular cells (heterocysts), as is shown by Professor Wool's figure, 1'. 3, Fig. 3, to the the case with the species from Camolen. Neither ean we regard S. Carmichalii, Harv., as a synonym of Cylindrospermum polyoporum, Kiith, as given by I'rofessor Went. Although we have examimed a large number of specimens, in only whe instance have we found more than a single spore on each sicle of the lecterocyst, which is quite different from C. polysperum, Kiits.

\section{NODULARIA, Mertens.}

(From nodulus, a little joint.)

Filaments free, trichoma inclosed in a definite sheath, cells discoidal. Ileterocysts at regular intervals. Spores numerous, contiguous, not adjiacent to the heterocysts.

The genus Spermosira of Kiitzing is included under the alove.

x. Hanveraxa, Thuret, Class. des Nostoch. (Spermosira Harreyana, Thraites, Phyc. Brit., Pl. 173c.)

Filaments curred, cells discoidal, .0015-20 $\times .004^{\mathrm{mm}}$, heterocysts $.0035^{\mathrm{mm}}$ in diameter, spores numerous, about $4-8$ together, spherical, $.005-70^{\mathrm{mm}}$ in diameter.

Charles River, Cambridge, Mass.; Europe.

Found in small quantities, mixed with spharozyga, in company with Ihizoclonium.

\section{SPIRULINA, Turpin.}

(From spirula, a small spiral.)

Filaments simple, without a proper sheath, oscillating, spirally twisted. Spores unknown.

S. Texurssma, Kuitz., Phye. Brit., Pl. 10J, Fig. 3; Farlow, List of

\section{Marine Algæe, 1876. P1. I, Fig. 4.}

Filaments intricately interlaced, $.0035^{\mathrm{mm}}$ in diameter, hyaline, spiral, closely twisted, cell divisions scarcely visible, oscillations rapid.

Lastport, Maine; Gloucester, Cambridge, Wood's Holl, Mass.; Europe.

This species is common at Eastport, where it forms, mixed with speciess of Oscillaria, dark purple-colored patches on the wharses at low-water mark, and it is without donbt to be foumd in similar localities along the whole coast.

We found at Wool's Holl, in 1-5it, a species of spirulina which formed a greenish filu on decaying alga five or six feet below low-water mark, and the same species was collected by Wr. F. W. Hoojur at Key West. It agrees closely with S. Thuretii, Crn., a species whith tiffers from S. Lenuissima, Kiitz., in having slightly smaller filaments, whirh are ales less tightly coilecl. It hardly seerns to us. howerer, as though the difference was sufficient to separate the two species. A spirulina with murel finet filaments than in S. temuissima, and with a mueh more open spiral, oceurs at Woul's Ifol!, but we have never fomml it in suffieient ynantity to ascertain the speries. 


\section{BEGGIATOA, Trevisan.}

(Named in honor of Francesco Secondo Beggiato, an Italian botanist.)

Filaments simple, hy̧aline, no proper sheath, rapidly oscillating, cells filled with opaque granules. Spores unknown.

A genus separated from Oscillaria only by its color, which is white to the naked ere, and by the granules of sulphur which often make the cell seem quite opaque when riewed with the microscope. The species gire off a strong odor of hydric sulphate, and are found in both fresh and salt water, especially in hot springs. The diameter of the filaments, an uncertain mark, is about the only guide to the distinction of the species.

B. ALBA, Treves, rar. InARINA (Warming; Videnskab. Middels., 1875, Pl. X, Figs. 6,7).

Filaments $.0036^{\mathrm{mm}}$ in diameter, cell divisions indistinct, granules usually irregularly placed.

Cambridge; Europe.

In brackish ditches.

B. ARAchroidea, Rab. (Tarming, 1. c., Pl. X, Figs. 2-4).

Filaments $.005-7^{\mathrm{mm}}$ in diameter, cells narrorrer than broad, granules usually in bands parallel to the transrerse cell-walls.

Eastport, Maine; Wood's Holl, Mass.; Europe.

On dead algæ.

B. Mirabilis, Cohn (Warming, l. c., Pl. X, Fig. 5).

Filaments $.016^{\mathrm{mm}}(20-40$, Warming) in diameter, cells a third as long as broad, granules arranged in bands.

Cambridge, Mass.; Europe.

There is a doubt abont the accuracy of the determination of the specimens referred to this species. It is much the largest of the genus found on our coast. The only specimens which we have measured were $.016 \mathrm{~mm}$ in breadth, which agrees with the measurement of Cohn, but not with that of Warming. We have the impression, however, that we have seen larger specimens than those measured.

Leptothrix rigidula, Kütz., is found at Wood's Holl, on Ectocarpus and other algæ. The genus Leptothrix is now limited to small species related to Bacillus. The present species is parasitic on Ectocarpus and Cladophora, on which it forms white fringes in midsummer. The filaments are about $.002^{\mathrm{mm}}$ in diameter. The cell divisions are very indistinct. The species may possibly be the same as Beggiatoa minima, Warming, 1. c., Pl. X, Fig. 10.

\section{OSCILLARIA, Kuitz.}

(From oscillo, to vibrate.)

Filaments simple, destitute of distinct sheath, oscillating, bluish green or dark purple.

The species of this genus are found on mud, wharres, and wood work. They are not usually found pure, but mixed with Spirulina, Lyngbya, \&c. The following are all to which we care to give a name, but not by any means all which occur with us. 
O. Lumoss, Kiitz., vat. char.rmea, Tab. Phyc.. Vol. I, Pl. 41, Fig. 3 ; Le Jolis, Liste des Algues Marines.

Filaments .005-9mo in diameter, flexums, apex obtuse, oscillations marked, cells ahout half as long as lnoad, purplish colored.

Eastport, Maine; Europe.

Forming a slimy layer on piles. Onr speximens seem to agree well with specimeng

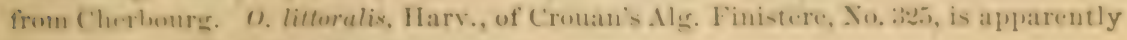
very near to this, if not the same.

0. stbulaforms, Harv, Pliye. Brit., Pl. 2.51 l.

Filaments $.006-2^{\text {mm }}$ in diameter, at the end tapering to an incurred point, cells about one-third as long as broad, bluish green.

Charles River, Cambridge; Europe.

O. strtortiosa, (Bréb.). (I'hormidium subtorulosum, Bréb., in Kiitz. Tab. Phye., Vol. I, Pl. 49, Fig. 5.)

Filaments .003-1 $4^{\mathrm{mm}}$, cells nearly cuhoidal, with rounded angles, so that the filament appears slightly crenate.

Eastport, Maine; Wood's IIcll, Mass.; Europe.

To this species is doubtfully referred a form common on wharves at Eastport and on the government wharf at Wool's Holl, where it forms slimy patches, mixed with spirulina, de. The filaments of this species bear a decided resemblance to thes trichomata of Microcolens chthonoplastes, and it may perhaps be a question whether they are not really a stage of that species in which the trichomata have escaped from the enveloping sheath. Opposed to this view is the large quantity of filaments and apparently an entire absence of empty sheaths. That the trichomata of M. (hithonoplastey often esrape from the sheath can easily be seen, but how long they remain freo and how rapidly they increase under such circumstances is uncertain.

\section{MICROCOLEUS, Desmaz.}

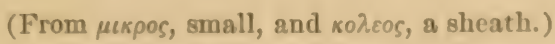

Zilaments slowly oscillating, destitute of heterocests, several united in a single gelatinous sheath, which is either simple or branching.

M. cirtmoxoplastrs, Thuret. (Oscillatoria chthonoplastes, LyngbyeChthonoblastus Lyngbei, Kiitz. - Microcoleus anguiformis, Harv., Phye. Brit., PI. 249; Kiitz., Tab. Phye., Vol. I, Pl. 57._Chthomollastus anguiform is, Rals., Flora Europ. Alg., Sect. II, p. 133.) Pl. II, Fig. 3.

Sheaths elongated, fusiform, being six or more times broaler in the center than at the extremities, simple, several twisted together so as to form a green stratum, filaments dark green, about $.005^{\text {mm }}$ in diameter, intricately twisted together, three or four only at the extremity of the sheath, but very numerous at the center, where the sheath is frequently muptured, allowing the filaments to protrude; cells as long as broad, or a little biomler, terminal cell arutely pointed. 


\section{Wood's Holl, Mass.; Atlantic shore of Europe. Summer.}

A species easily recognized and probably common along the New England coast in summer, but rarely found in sufficient quantities to make herbarium specimens. It is usually found in small streaks, so entangled with other Nostochinea and Conferva as to be quite inextricable. At times it is found tolerably pure on the old stalks of Spartina, between tide-marks. Pure specimens may be obtained by allowing specimens in which filaments of this species are entangled to remain overnight in a shallow dish of salt water, when the Microcoleus will have freed itself from other substances and come to the surface. As generally found, the plant looks like an attenuated cornncopia, owing to the rupture of the sheath in the middle, allowing the filaments to project. This is shown in Harvey's figure, l. c., and also in Pl. II, Fig. 3, where only half of the plant has been drawn. Normally the sheaths are about a quarter of an inch long, about $.075^{\mathrm{mm}}$ broad in the middle, and tapering to about $.012^{\mathrm{mm}}$ at the ends. Color a deep bluish green. The filaments readily escape from their sheath, and might in this condition pass for a species of Oscillaria.

Microcoleus terrestris, Desmaz. (Chthonoblastus repens, Kütz.), and M. VersiCoLor, Thuret, are not infrequently found in muddy places in the interior of New England.

\section{LYNGBYA, Ag.}

(Named in honor of Hans Christian Lyngbye, a Danish botanist.)

Filaments free, each provided with a distinct sheath, simple, destitute of heterocysts, no proper oscillations. Spores unknown.

\section{MaJuscula, Harv.; Mermaid's Hair. (Conferva majuscula, Dillw.-} I. crispa, Ag. in part,-L. majuscula, Harv., Phyc. Brit., Pl. 62; Ner. Am. Bor., Part III, p. 110, Pl. 47 a.) Pl. I, Fig. 4

Filaments long, forming floating tufts, crisped, about .028 $\mathrm{mm}$ to $.032^{\mathrm{mm}}$ in diameter, blackish green, sheath prominent, cells 8 to 10 times as broad as long.

Cape Cod, Mass., to Key West; Europe; Pacific Ocean. Common and widely diffused. Summer.

The largest, most striking, and most common of our marine Lyngbyre, easily recognized by the length and diameter of its filaments and its color, which is a blackish green. It forms during the later summer months large tufts upon Zostera and various other algæ, and is often found floating free in considerable quantities. In the center of the masses the filaments are intricately twisted together, but on the surface they float out from one another, so as to deserve the common name of mermaid's hair. In the older specimens the filaments are very much curled and twisted, forming the $L$. crispa of some writers. The sheath is always well marked, although, as is the case in all the species, it varies so much in thickness under different circumstances as to render it impossible to give accurate measurements. The heterocysts, "cellulis interstitialibus sparsis," described by Rabenhorst in this species, Flora Europ. Alg., Part II, p. 142, have, in reality, no existence.

L. Aestuarir, Liebm. (L. cruginosa, Ag.-L. ferruginea, $\Delta \mathrm{g}$., in Ner. Am. Bor., Part III, p. 102, Pl. 47 b; Phyc. Brit., Pl. 311.)

Filaments forming a verdigris-green stratum, about .016-18 ${ }^{\mathrm{mm}}$ in diameter, sheaths distinct. 
Gloncester, Mass, Mrs. A. L. Daris, and southward; Enropes. Sum. mer.

A common species of the New England coast, alumblant in shaliow, lrarkish peols. where it corers the expresel alga and Zostera. Much less striking than 2. mejuscula, Harv., from which it is distingnished at sight by its hrighter green color, changing to yellowi-h rather than blackish, by the diameter of its filaments, which is alwot half that of $l$. majuscula, hy its thinner sheath, and hy forming thin strata rather than loose tnfts. In the Ner. Am. Bor., Part III, the diameter of the filanents of L. majus-

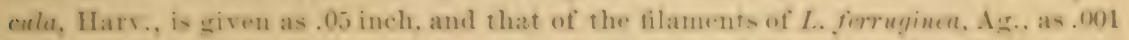
inch, which is evidently incorrect, as one species is not fifty or erron five times larger than the other.

L. Ltro-fusca, Ag. (L. fulta, Harv. Ner. Am. Bow, Part III, p. 102, Pl. $47 f$.)

Filaments fasciculate, exect, greenish yellow, .008-10 $\mathrm{m}$ in diameter, sheath distinct.

Exs.-Alg. Am. Bor., Farlow, Anderson \& Eaton, No. 4s.

Stonington, Comn., Bailey; Yoank, Comn.; Wool's IIoll, Mass., W. G. F.; Europe.

Apparently a common alga of Sonthern New England, diffiering in its haluit from all our other species of the genns, except $L$. tenerrima. It grows in large patches on stones and wood-work between tide-marks. The filaments are erect, from one to three inches high or somewhat higher, when in their best condition olive-colored, but more frequently a pale yellow. The thickness of the sheath, by which Harvey separated his $L$. fulva from $L$. luteo-fusea, Ag., is by no means constant, and the sprecies cammot be kept distinct. As is the case in several of the species of Lymglbya, the sheath is sometimes two, three, or even a greater number of times thicker than at others.

\section{TENERrima, Thuret, mser.}

Filaments slender, fascieulate, erect, bluish green, $.0035^{\mathrm{mm}}$ in diameter, sheaths very thin.

Gloucester, Mass., Mrs. A. L. Daris; Newport, R. I.; Europe.

This species was first detected near Gloucester, hy Mrs. Davis, growing apparently on sand-onvered rocks. The filaments are bluish green, and not over a quarter of an inch high. The species will be easily recognized hy the diameter of the filaments, which is decidedly less than that of any other of our species. Dr. Bornet, to whom a spm-imen was sent, considers our plant the same as that collected lyy the late $\mathbf{M}$. Thuret, at Biarritz. France, and naned by him L. tenerrima. I have since found it in comsihetable quantity at the base of the cliffs near the Winans mansion, at Newport.

L. vminescess, Harv, Yer. Am. Bor, Part III, p. 102, Pl. $47 d$.

" Filaments very slender, flaccid, densely interworen into a fleecy, blackish-green stratum." (Harrey, l. c.)

Camarsic Bay, L. I.. Hooper; Peconic Bay, Harey; on mud and on Zostera, Gloucester, Mass., Mrs. A. L. Daris.

Var. Ma.Jor.

Filaments forming a dark.brown gelatinous stratum, $.0152^{-m}$ in diameter, sheath thin. 


\section{Wood's Holl. Common on Zostera. Summer.}

From Harvey's description, it would be difficult to recognize this species. From an authentic specimen in our possession, collected by Harvey at Peconic Bay, tho filaments are seen to be from $.0035^{\mathrm{mm}}$ to $.01115^{\mathrm{mm}}$ in diameter. The sheaths are distinct, but less marked than in $L$. cestuarii, from which the present species differs in the shortness and smaller diameter of the filaments, aud in the color, which is a dark purple, at times almost black. The filaments differ from those of both L. majuscula and $L$. (estuarii in being held together by an amorphons, gelatinous substance, supposed to be characteristic of the genus Phormidium. That genus, however, includes plants which are now properly assigned to other genera.

We have often searched for this alga, but have never found a form which seemed to correspond exactly to Harvey's specimen. The same alga has, however, been collected by Mrs. Davis at Gloucester. At Wood's Holl is a Lyngbya, distributed in Alg. Am. Bor., Farlow, Anderson \& Eaton, No. 47, which is not uncommon, forming patches sereral inches long on Zostera, and which resembles $L$. nigrescens closely in everything but the greater diameter of the filaments. Its sliminess and the delicacy of the filaments cause it at first sight to be mistaken for diatomes. In drying, it becomes somervat greenish. This species, which resembles closely L. Kützingiana, Thuret (Phormidium, Le Jolis), we can regard only as a large variety of Harvej's $L$. nigrescens.

CALOTHRIX, (Ag.) Thuret.

(From $\kappa a \lambda o s$, beautiful, and $\vartheta \rho \iota \xi$, hair.)

Filaments terminating in a hyaline hair, fixed at the base, free above, occasionally branching, growing in little tufts or strata of indefinite extent, heterocysts present in most of the species, no oscillations. Spores unknown.

We adopt the genus with Thuret's limitations, including, in part, the genera Schizosiphon, Amphithrix, Leibleinia, \&c., of Kützing.

a. Species growing in little tufts.

C. confervicola, Ag. (Leibleinia chalybea and amethystea, Kütz.C. confervicola, Ag., Phyc. Brit., Pl. 254; Notes Algologiques, Pl. 3.) Pl. I, Fig. 6.

Tufts fasciculate, filaments dark bluish purple, attenuated, $.018^{\mathrm{mm}}$ in diameter, heterocysts all basal, generally few in number.

On algæ of all kinds. Summer. Very common. Europe.

C. CRUstaceA, (Schousb.) Born. \& Thur. (Schizosiphon fasciculatus and lasiopus, Kütz._Oscillatoria crustacea, Schousb._Calothrix crustacea, Bornet \& Thuret, Notes Algologiques, p. 13, Pl. IV.)

Tufts fasciculate, filaments bright green, attenuated, $.0125^{\mathrm{mm}}$ in diameter, heterocysts intercalary, often very numerous.

Exs.-Alg. Am. Bor., Farlow, Anderson \& Eaton, No. 49.

On algæ of all kinds, and on rocks. Summer. Very common. Europe.

The two species just described are very common, certainly from Wood's Holl to New York, and probably also northward, on all kinds of algæ, on which they form fine tufts or fringes. The two species usually grow mixed together, but may be 
cavily distingnished under the microsenpe, $C$. conferrionla being darker colored, the filaments thicker, and only furnished with heteroeysts at the base, whereas in $C$ crustacen the heterocysts are seattered through the filament, often sulitary, lout sometimes as many as eight together, amb frefuently truneate. C. crusturea is also common on rocks.

\section{b. Species forming expansions.}

C. scoptlontar, Ig., Phye. Brit., Pl. as h; Ner. Am. Bor., Part III, p. 105.

Filaments forming stratia of indefinite extent, flexumus, usually branching, .00s-12mu in diameter, heterocysts basal and intercalary, sheaths thick, striate.

Var. viresia. (C'. viripara, Harv., Ner. Am. Bor., Part III, p. 106.)

Silhant, Wood's Holl, Mass., W. G. F.; Iihode Island, Bailey; Europe. Var. vicipara at Nahant, W. G. F., and Seacommet P'oint, Bailey.

Fomaing indefinite-shaped patehes on rocks, on lihizoclonium, and other prostrate algap. Apparently much liss common than the two preceding species. It diffirs from C. crustacea in the flexuons hahit of the filaments, which are loosely twisted aromml one another, in the much rarer ocenrrence of interealary heterocysts, and in the color of the filaments, which is not a bright green, but generally brownish. The sheathe, too, become thick, dark, and striated. As is the case in all species of Calothrix where the filaments are closely interwoven, the diameter of the filaments is greater and that of the sheath less, proceeding from within ontwarls. The variety riripara is only a luxuriant form of the typical species.

C. pulvinata, Ag. (C. hydnoides, Harv.)

Filaments densely packed, forming a dark green spongy layer, united at the surface in tooth-like masses, flexuous, .006 $6^{\mathrm{mm}}$ to $.0115^{\mathrm{mm}}$ in diamcter, heterocysts intercalary.

Exs.-Alg. Am. Bor., Farlow, Anderson \& Eaton, No. jo.

Tood's Holl, on wharres. Common. Europe.

In this species the filaments are much more densely interworen and flexumus than in any of the preceding species. It forms patches looking like a honeycomb, or like as suall IIydum, and can be torn from its attachment in pieces of considerable size.

C. Panasitua, Thuret. (Rivularia, Chauvin.-Schizosiphon, Le Jolis.)

Filaments loosely united, forming a velvety film, bullons at base, simple or only slightly branching, about .00S-10 $0^{\mathrm{mm}}$ in diameter, heterocysts basal, obliquely truncate.

On Semalion multifilum, Newport, R. I.; Europe.

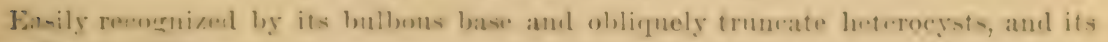
Imeculial habitat.

\section{RIVULARIA, Roth.}

(Named from the fluviatile habitat of many of the species.)

Frond gelatinous, more or less globose, filaments radiating, attenuated, furnished with distinct sheaths, branching, a heterocyst at the base of each branch. 
Few genera of algie have been divided by different writers into so many artificial and unsatisfactory genera as Tivularia. Some of the described genera are characterized by striations or alterations of the sheath which arise from age or unfarorable exterval conditions. Other so-called genera are characterized by the presence of parasitic plants in the thallus of a true Rirularia. As understood in the present article, the genus differs from Calothrix in the fact that the filaments are imbedded in a mass of jelly and the thallus is of a definite shape and extent. From Isactis, which might be perhaps considered a sulogenus, Rivularia differs in having its filaments radiate from a central point instead of being parallel to one another. From Hormactis it abundantly ditiers in the mode of formation of the filaments. In Rivularia the branches are formed by the division of the filament lateralls, the upper part of the branch separating from the main filament, and the two being onls in contact at the base of the branch, where a heterocyst is alwars to be found. In Hormactis the filaments push out sidewise in the form of an inverted $\mathrm{V}$. The apex of the $\mathrm{V}$ then elongates upwards and, at the same time, the sides of the V elongate so that, in passing from the interior of the thallus outwards, instead of finding a series of filaments spreading out fan-shaped, we find the filaments converging two by two, which finally unite into single filaments near the surface of the thallus. Moreorer, the heterocssts in Hormactis are intercalars, not basai. In none of our marine species of Riculuria have spores been seen, but spores are found in some fresh-water species of Glacotrichia, a genus closely allied to, if not to be included in, Rivularia.

R. ATRA, Roth. (Zonotrichia hemisparica, Ag.-Euactis amona, atra, confluens, hemispharica, Lenormandiana, marina, Kiitz.-Linckia atra, Lyngb.-R. atra, Phyc. Brit., Pl. 239.) Pl. II, Fig. 2.

Thallus solid, globose or hemispherical, varying in size from that of a head of a pin to half an inch in diameter, dark glossy black, filaments straight, .0038-45 $5^{\mathrm{mm}}$ in diameter, heterocysts about as broad as or rather broader than the filaments, usually somerhat pointed.

Var. confluens, flattish, owing to the coalescence of sereral individuals.

Common along the whole coast, on stones, algæ, and stalks of Spartina, often in company with Isactis plana. Distinguished by its dark, shining color and usually hemispherical shape. It is generally minute in size, but occasionally grows as large as a pea or somewhat larger. The rariety confluens resembles, to the naked eje, Isactis plana, but is decidedly thicker. Microscopically the two are quite different.

\section{R. Plicata, Carm., Phyc. Brit., Pl. 315̃. (Physactis, Kütz.)}

Thallus at first solid, soon becoming hollow, plicato-rugose, folds sinuous, filaments flexuous, .003-4 ${ }^{\mathrm{mm}}$ in diameter, heterocysts nearly spherical, about as broad as the filaments.

On mud and Spartina roots. Cohasset Narrows, Woòd's Holl, Mass., W. G. F. Common.

Although as jet known to occur only at the two abore-named localities, this species will probably be found to be common along the whole New England coast, but it is certainly less common than the preceding species. Its farorite habitat is the mud in which Spartina is growing, between tide-marks. It attains a larger size than $R$. atra, is almost always hollow, and easily recognized by its cerebriformly plicate surface. The substance is softer than in $R$. atra, the filaments are slightly narrower and less closely packed together, and the heterocysts are rather more spherical than in that species.

R. Hospita, Thuret (Euactis hospita and prorumpens, Kütz.), which differs from the. 


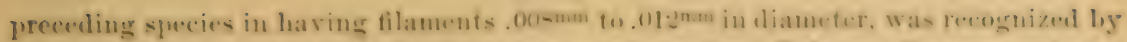

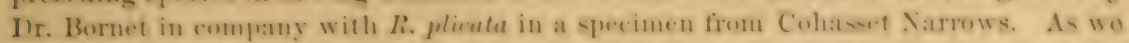
have not heen able to recognize the species in any of onr own spuerimens from the same locality, the preamption is that it is net very common.

ISACTIS, Thuret.

(From toos, equal, and uктьৎ, a ray.)

Frond plane, composed of parallel filaments, held together by a tough, gelatinous intereellulitr substance, ending in a hyaline hair, heterorysts basal, ramitications few. Spores unknown.

This semus difters from licularia only in that the filaments are parallel to one

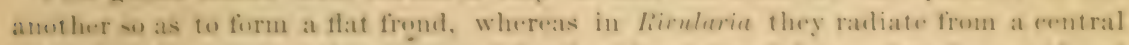
point and form more or less splerieal fronels. It uight with propurety be considered a subgenus unter Ritularia.

I. PLaxa, Thuret, I. c. (Dasyuctis, Kiitz-Physactis atropurpurea, obducens, Kiitz.) Pl. I, Fig. 2.

Frond flat, thin, dense, dark green, outline irregular, filanents $.00-6-95-\mathrm{m}$ in diameter, $.12-.15^{\mathrm{mm}}$ high sheaths often torn and striate.

\section{Whole New England coast; Europe.}

Very common on rocks. Furne, Puncteria, and of her algar, forming dark-errents s]ots, scarcely raised above the sulustance on which it is growing.

HORMACTIS, Thuret.

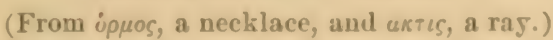

Frond gelatinous, globose, at first solid, then hollow and plicate, heterocyst intercalary, filaments simple at the surfiare of frond, bifurcating below. Spores unknown.

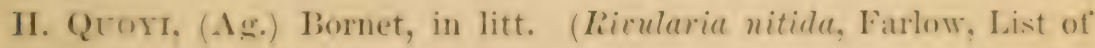
Marine Algr, 18i6. Pl. II, Fig. 1.

Fronds gregarious, dark green, plicato-rugose, from a quarter of an inch to two to three inches in diameter, filaments .0025-ji-m in diameter, tortmons, cells of external part of the frond thick and discoidal, becoming more oval in the interior of the frond heterocysts numerous, scattered, about $.0038^{\mathrm{mm}} \times .0058^{\mathrm{mm}}$.

Exs.-Alg. Am. Bor., Farlow, Anderson \& Eatom, Mo. 4.

Wood's Holl, Mass., W. G. F.; Falmouth. Mass., Mr. F. S. Cullins : Marianne Islands.

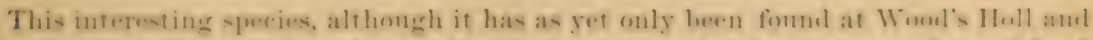

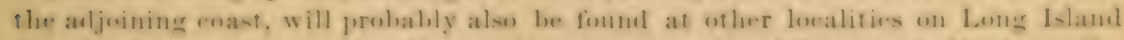
sonul. It grows in considerable quantities upon -peecies of Fuens, at half tide, on the inner side of Parker's Peint. Wood's Holl, and we have alon foumel it washed ashere on the leacheres of Buzzaril's liay, in the same township. It makes its appearance in June, and disappears in the month of September, le.ing in perfiection in the month of July. The fronds sometimes acquire a large size, $t$ wo or three inelies in dianeter, hut ustaily they are mueh smaller and densely aggregated, almost cosering the Fueus 
stalks upon which they are growing. It first appears as solid green spots upon the Fucus, which soon swell out into thin bladders, which partly collapse on being removed from the water. The peculiar inverted $V$-shaped filaments are seen to greater advantage by dissecting with needles small pieces of the frond than by making sections with a razor.

The only other species of this genus is Hormactis Balani, Thuret, which grows on barnacles on the coast of France. It is a comparatively minute plant, much less striking than our own species, which seems rather to replace, on our coast, the Rivularia nitida, Ag., of the coast of Europe, which it resembles in general appearance and habit. The external resemblance to that species is so great that specimens were sent to Dr. Bornet as $R$. nitida, Ag. (?) By him it was recognized as a new species of Hormactis, H. Farlowii, under which name it was distributed in Alg. Am. Bor. Since then Dr. Bornet has recognized its identity with Rivularia Quoyi, Ag., of the Marianne Islands. It is not a little remarkable that the species is only known in two localities so widely remote from one another.

Stigonema mamilosum, Ag., occurs in a brook which empties into the sea at Rafe's Chasm, Magnolia Cove, in Gloucester ; and Calothrix Parietina, Thuret, is found in Nobska Pond, close to the sea, at Wood's Holl. The species named all belong in the present order, but are not strictly marine.

\section{ORDER ZOOSPOREA}

Algx either green or olive-brown in color. Reproduction by meaus of zoospores, which unite in pairs to form a zygospore.

This order includes all the marine Clorospermece attributed to New England in the Nereis Am. Bor., with the exception of the genus Vaucheria, as well as the greater part of the olive-brown sea-weeds, with the exception of the rock-weeds or Fucacea. The account of the order given in the introduction to the present article should bo consulted in the present connection.

a. Green algæ, multicellular, zoospores of two kinds-macrozoospores with four and microzoospores with two terminal cilia.. Chlorosporex. b. Green algæ, frond unicellular, branching ............ Bryopsidea.

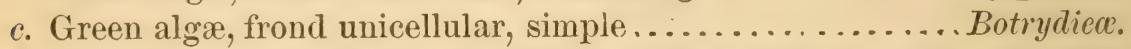
d. Ulire-brown algæ, zoospores of one kind, with two cilia laterally

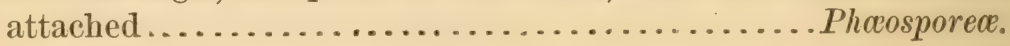

\section{Suborder CHLOROSPOREÆ.}

1. Fronds membranaceous ........................ Ulva $)_{2}$

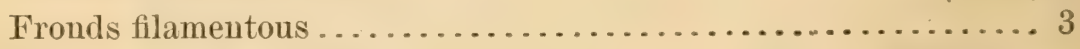

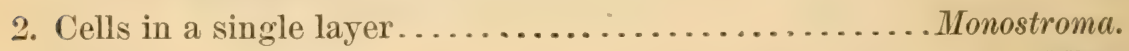
Cells in two layers............................. Ulva.

3. Some of the cells furnished with long hyaline hairs..... Bulbocoleon. Cells destitute of hyaline hairs...................... 4

4. Filaments branching throughout................... Cladophora. Filaments with short, root-like branches only........ Rhizoclonium. Filaments unbranched ........................ 5

5. Filaments rigid, setaceous ....................... Filaments soft and flaccid..................... Ulothrix. 


\section{MONOSTROMA, (Thuret) Wittrock.}

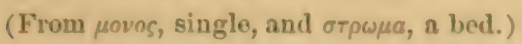

Fronds membranaceous, consisting of a single layer of cells, which are either parenchymatous or separated from one another by more or less jelly.

As defined by Thuret, Monostroma differed from Tha in having the cells embediont in jelly rather than arranged in the usual form of parenehymatous tissue. Wittrock incluales in the grenus all the Cleo consisting of a single layer. In most of the species the froml is at first sack-shape, but soon ruptures, the segments being composed of one layer of colls. The basal cells are prolonged downwarls, lout they become more or bess circular in the upper part.

\section{PULCIRUM, n. sp.}

Fronds membranaceous, fasciculate, light green, lanceolate or cuneatelanceolate, attenuated at the base, margin crisped, two to twelve inches long, two inches broad, substance very delicate, about .006 $\mathrm{mm}$ in thickness, cells irregular, more or less sinuous, intercellular substance small.

Wateh IIill, Conn., Prof. Eaton; Gloucester, Mass., Mrs. Bruy; Portland, Me., Mr. C. B. Fuller. Spring.

A beantiful and apparently not uncommon spring plant of New England, distingrished by its outline and delicate substance. When fully grown the fromels are most frefuently attenuated at the base and rather obtuse at the summit. When young they are lanceolate, and seem to be always plane, never saccate, as in the next species. The color is a delicate green, and the plant camnot easily be removed from the paper on which it is pressed. This species has sometimes been distributed as Clia Linza, to which it bears more or less resemblance in shape.

M. Greviller, Wittrock. (Ulra Lactuca, Grer, non Linn.; Harr. Pliye. Brit., P'. 243, and Ner. Am. Bor., Part III, p. 60.-Enteromorpha Grerillei, Thuret.)

Frond at first saccate, then split to the base into irregular segments. color light green, segments plane, unequally laciniate, frond about $.012^{\mathrm{mm}}$ thick, cells angular, intercellular substance small.

Joston Bay (Ner. Am. Bor.); Malden, Mass., Mr. Collins; Ires I'oint, Conn., Mr. F. W. Hall; Europe. Spring.

A rommon spring species of the Atlantie shores of Europe, but apparently not so common in New England. The cells of this species vary considerably, anch, in sume specimens the intercellular gelatinous sulistance is tolerably prominent.

M. Buytr, (Aresch.) Wittr. (Clia Blytii, Aresch., Pliye. Scand., p. 186, Pl. 10 g.-M. Iilyttie, Wittrock, Monog. Monostr., p. 49, Pl. IV, Fig. 11.)

Frond membranaceous, sulsoriaceons, dark green, irregularly cleft, margin crisped, .025-10 m- in thickness, cells angular, closely packed, intercellular substance small.

Exs._- Yordstedt \& Wittrock, Alg. Scand., No. 44; $\mathrm{Alg}$. Am. Bor., Farlow, Anderson \& Eaton, No. 98. 
Eastport, Maine; Gloucester, Nahant, Mass.; Northern Europe. Autumn.

This, by far the most striking of our Monostromata, grows luxuriantly in the large tirle-pool at Dog Island, Eostport, where it attains a length of one foot. In labit it resembles Clia lactuca var. rigida, but it is of a deeper green. Our specimens were collected in the month of September. As it occurs at Nahant the species is not generalls more than two or three inches long, and recalls the figure of Clia obscura, Kiitz., Tab. Pbyc., Pl. 12, No. 2. It is found in the clefts of exposed rocks, late in the season. Its color is a deep green when growing, which becomes brownish in drying. It does not adhere well to paper.

M. CREPIDINUM, n. sp.

Fronds delicate, light green, one to three inches long, flabellately orbiculate, split to the base, segments oborate, .01S-36 $\mathrm{mm}$ thick, cells roundish-angular, intercellular substance prominent.

Gorernment wharf, Wood's Holl, Mass. August.

This small species is common on the piles of the wharf at Wood's Holl. It is very soft, and collapses on remoring it from the water. It preserves its color well on paper. The above name is given provisionally, as we are not able to refer the species to any known form. It resembles M. Wittrockii, Bornet, a species, we believe, not yet described. Except in its small size, it is rery near $M$. orbiculatum, Thur., but the thickuess of that species, as given by Wittrock, is .032- $40 \mathrm{~mm}$. Ail examination of a specimen collected by Thuret, however, gives the same measurement as our species. If the species erentually is united with $\mathscr{Y}$. orbiculatum, the present must be regarded as a small form.

ULVA, (L.) Le Jolis.

(Supposed to be from $u l$, Celtic for water.)

Fronds simple or branching, consisting of two layers of cells, which are either in close contact with one another or else at maturity separate so as to form a tubular frond.

We have followed Le Jolis in uniting the old genera Ulra and Enteromorpha, and we might perhaps have gone farther and united Monostroma with Ulva, for if Monostroma Grevillei when young resembles an Enteromorpha, in its older stages it splits into membranes consisting of a single layer of cells, which are certainly imbedted in a certain amount of gelatinous substance, yet so little as to make it doubtful whether to call the frond parenchymatous or not.

U. Lactuca, (Linn.) Le Jolis. ( Clva latissima and rigida, Ag. \& Auct. recent.-U. latissima, Grev. \& Harr.-Phycoseris gigantea, myriotrema, australis, \&c., Kiitz.) Pl. III. Fig. 1.

Frond flat, thick, unbranched, rariously more or less ovate in outliue, dirided, the two layers of cells adherent.

a. Var. RigidA, (Ag.) Le Jolis. (U. rigida, Ag.- - . latissima, Harr., Phyc. Brit., partim.-Phycoseris australis, Kiitz.)

Frond rigid, rather thick, generally deeply divided, lacinia irregularly lacerate-erose, the base of frond more dense and deeply colored than the rest. 
3. Var. I.actica, Le Jolis. (U. latissima, Harv, partim.-Phycoseris giganten, Kiitz.)

Frond orbienlar, oblong or elongate-tisciate, simple, undirided or searcely lobecl, frequently spirally contorted.

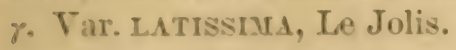

Froml -imple, at first cumeate-subitipitate, afterwards broally expamilerl.

Very cotamon all over the workd, especially in lrackish waters.

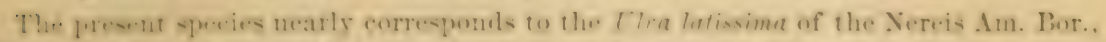
beis is unt the $t$. Latum of that work. It is tistinguished from the remaining speeries ly beng ahways flat, never tubular at any atre. and by its more or less orbienlar ont-

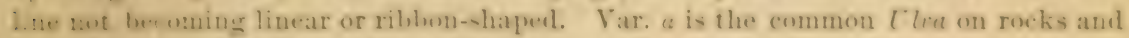
tin pools exposed to the action of the waves. The front, althongh not rery large, is 1ighl, and does not whlhere well to paper in drying. In outline it is orhienlar, and is gwerally deeply ineised. Tar. 3 has a more elongated shape, and is generally plicatoundulate. Var, is very common in brackish places on the mul, and attains a very harge sice. When fully grown it has no definite shape, but is raggred on the nargin and often perforated.

Clva exteromorpita, Le Jolis.

Frond linear or lanceolate in outline, attenuated at base, the two layers of cells either entirely separating, so as to form a tubular frond, or sliglutly cohering, forming a flat frond.

a. Var. Laxceolata, Le Jolis. (Llea Linse, Grevilie d Harrey.Pliycoseris lanceolata and crispata, Kiitzing.)

Frond narrow, that, ribbon-shapeel, unbranched, much attenuated at hase, margin somewhat crisped, sometimes so much so that the frond appears spirally twisted.

3. Var. notestrands, Le Jolis. (Enteromorpha intestinulis, Auct.)

Froul simple. attenuated, and subcompressed at base, above tubulosoiuflated.

r. Var. Compressa, Le Jolis. (Clea compressu, L.-Entemompha compressa, Auct.)

Froml tubuloso-compressed, generally proliferously branched, branches uniform, simple, attenuate at the base, broaller and obtuse at the aprex, color somewhat dingy.

Very common all over the world, particularly in brackish water.

This querins inclnies the Tlia Linza. Enteromerpha intelinalis, and Entromorpha comjuene of the Xerris Am. libr., which ean only be regarded as varieties of ase spereies. The epecies reaches its highe-t derelopment in the rar. 3 (Enteromerpha intestinalis,

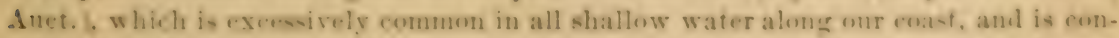
spicuousiy disagreeable loy its resemblance in shape to the swollen intestiaes of some antma!. The speries approaches Llea Lactuca, L.., in var, c, wheh is not so common as the or her furms of the species whose long ribon-like fronds are compresect insteal of iulniar, as in sar. 3 . In var. n, with braneting iustrad of simple fromels, the 
species approaches Ulva clathrata. Innumerable varieties have been made of the various forms of this species, but an enumeration of them is quite uncalled for in this place.

Ulva clathrata, Ag.

"Frond tubular, filiform, several times branched, branches attenuate at the apex, often very fine, cells arranged in rows." (Le Jolis, Liste des Algues Marines de Cherbourg.)

As usually defined by algologists, Ulva clathrata differs from $C$. compressa principally in the smaller size of the branches, a character by no means constant. We quote the specific distinctions as given by Le Jolis, l. c., which express more clearly than the descriptions of other writers the relations between the species:

"I think they (the specific characters) are to be found, first, in the general form of the fronds, which, broadened at the summit in the different rarieties of Ulva enteromorpha, are, on the contrary, much attenuated at the extremity in Ulva clathrata. Secondly, in the ramification. While Ulva compress $a$ and intestinatis are rather proliferous than branching in the true acceptation of the word-their branches being ordinarily of such a character that when they are given off from the lower part of the frond there does not exist, so to speak, any principal axis, or when borne towards the extremity of the frond reduced to simple proliferations; in Ulva clathrata, on the contrary, there exists a well-marked ramification, the fronds or primary axes bearing numerous secondary branches, which in their turn produce branchlets of an inferior order."

-Of the species, as defined by Le Jolis, there are several varieties common on our coast, principally to be distinguished by the fineness of the branches and more or less complicated ramification. The variety Agardhiana of Le Jolis (Enteromorpha Linkiana, Grev.), rather coarse and rigid, is common in shallow water, as is also the form called by Harvey Enteromorpha ramulosa. The var. Rothiana forma prostrata is found in a ditch at Malden, Mass.

Ulva Hopkrnki, (McCalla) Harr., Phyc. Brit., Pl. 263.

Frond capillary, excessively branched, ramuli ending in a single row of cells.

Greenport, L. I., Mr. Hooper; Gloucester, Mass., Mrs. A. L. Davis; Europe.

A beautiful species, looking much more like a fine Cludophora than an Clia. It is in most cases easily recognized by its tenuity and light-green color. It grows in large tufts on other algæ and is about eight or ten inches loug. It is by no means certain that this species should not be regarded as an extreme rariety of $C$. clathrata in spite of the fact that the branches usually end in a single row of cells.

ULOTHRIX, (Kuitz.) Thur.

(From $i \lambda \eta$, a forest, and $\vartheta \rho \iota \xi$, a hair.)

Filaments grass-green, soft and flaccid, unbranched, at first forming tufts attached at the base, afterwards becoming more or less entangled, cells never long in proportion to their diameter.

The genus Ulothrix here includes all the unbranching marine Chlorosporea of a delicate texture, and embraces the species included by Harvey in the genus Hormotrichum of Kützing, which can hardly be kept distinct from Ulothrix, an older geuus of Kützing. When young the species of the genus are attached at the base and unbranched, but in some cases, when old, the filaments are twisted together, and it is not always easy to find the point of attachment. 
The genne is too nearly related to Chatomorpha, from which it dithers in sulstanere the tilaments heing more or less grelatinoms in Clothrix and rigid in Chatomorpha. of

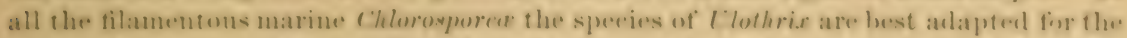
stuly of zoospores. The conjugation of zoospores in Flothrir zonata, a fresh-water

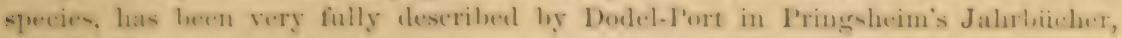
Vol. $\mathbf{x}$.

U. FLaces, (Dillw.) Thuret. (Lynglyyg flacea and Carmichaelii, IIarv., P'lye. Brit. I'l. 300 and 156 a. - Hormotrichum Carmichaclii, Harv., Ner. Am. Bor., Part III, p. 90.)

Filaments fine, lubricous, greenish yellow, one to three inches long, at first tufted, then entangled and forming strata of indefinite extent filaments $.014-30^{\mathrm{m}}$ in diameter, becoming moniliform, ectls .003-12 long, generally narrow, discoidal.

Eastport, Maine., on stones and Rhodymenia, August; Nahant, Malss., Mr. Collins, spring; Isles of Shoals, N. II., Mrs. Daris ; Europe.

A species most luxuriant in the spring, but also found in summer. The form fomml at Eastpert was the entangled stage which is common on wood-work at low-water mark.

C. Isogoxa, (Engl. Bot.) Thuret. (Conferra Youngana, Iarv., Phyc. Brit., Pl. 32s.-Lyngbya speciosa, 1. c., I'l. 186 b.-Hormotrichum Iounganum, Ner. Am. Bor., Part III, p. 89.-Urospora penicilliformis, Aresch. in part.)

Filaments fine, yellowish green, one to three inches long, at first tufted, afterwards forming strata, filaments $.036-\tilde{5}^{\mathrm{mm}}$ in diameter, moniliform, cells .01j- $0^{\mathrm{mm}}$ long, from cuboidal becoming ovate, constriction at nodes marked.

New York, Harrey; Ires Point, Conn., Mr. Hall; Gloucester, Mrs. Inaris; Nahant, Mr. Collins; Europe. Spring.

Distinguished from the last by its greater size and by the marked constriction lestween the cells at maturity. Apparently common on wool-work. Whatever name we may give to this species, it is the same form which is common in the northern part of Europe in spring and summer. It is the IIormotrichum Founganum of British authors, and the $C$, isogona of the French. It is the species referred by Areschoug, Glservationes I'hycologica, II, Act. Reg. Soc. Scient, Ser. III, Vol. 9, to Conferra penicill:formis. Roth, and made by him the type of the genus Crospora. Areschoug unites uncer the single species $C$. penicilliformis the following species of Phycologia Brittanira: Lynglyyu speciosa, L. Curmichuelii, L. Gutlerio, L. flacea, and Conferva Youngana. In the present case we have liept $C$. flace and $C$. isogona distinct, but agreo with Arechoug in uniting $l$ : speciosa with $C$. isogona. Perhaps a further acquaintancio with the species might lead us to unite the present two species under Areschoug's name.

The "IIormotrichum sperienum of Eaton's list of Lastport algate belongs to another genus. The $H$. boreale, $1 . \mathrm{c}$, is unknown to me.

U. collabexs, (Ag.) Thur.? (Comferca collabens, Marr, Phye. Brit., Pl. 327.-Hormotrichum collubens, Kiitz., Spec. Alg., 1. 353.)

Filaments tufted, two to six inches long deep green, cells from .0.5- 
$.18^{\mathrm{mm}}$ in breadth, once or once and a half as long as broad, nodes constricted.

To this species is referred, with considerable doubt, a rare Clothrix found by Mr. Collins at Nahant. The filaments are six or seven inches long. ver̦ soft, and they can with difficulty be removed from the paper on which they are pressed. The cells average from .035-90 mm in breadth by .054-.324 $\mathrm{mm}$ in length. In Rhode Island Plants, by S. T. Olney, Proridence Franklin Society, April, 1847, under No. 1189, is the following: "Conferta collabens, Ag.? 'or near it'-Harv. MSS. Sogonnet Point! Narragansett Pier!" In the Nereis Am. Bor., Part III, no reference is made to C. collabens, Ag., by Harres, whom Olney quotes in his list. Harvey, howerer, in the Nereis, describes a new species, Chatomorpha Olneyi, which calls to mind $C$. collabens, and perhaps that is the plant referred to by Mr. Olney.

\section{CHATOMORPHA, Kütz.}

(From $\chi a \iota \tau \eta$, hair, and $\mu \circ \rho \phi \eta$, shape.)

Filaments grass green, coarse and rigid, unbranched, either attached in tufts or floating in masses, cells rariable in length, often much longer than broad.

The species of this genus may be divided into two grotups. In the first the filaments arise in tufts from a definite base. In the second the filaments are twisted together and form intricate masses, which rest upon stones and other algæ. It may be a question whether the members of the last-named group are not the advanced stage of the species of the first group, which, as they have developed, have become twisted together and torn from their attachments. It would be comparatively a simple matter to classify our own species taken by themselves, but in comparing them with foreign species it becomes very complicated in consequence of the confusion of names applied to some of the common European species. We can only briefly mention the synonyms, which are almost hopelessly confused.

C. melagonium, (Web. \& Mohr.) Kiitz. (Conferva Melagonium, Phyc. Brit., Pl. 99 a.)

Filaments erect, base scutate, coarse and wiry, dark glaucous green, cells .4-5 ${ }^{\mathrm{mm}}$ broad by .4-7 $\mathrm{mm}$ long.

In tide-pools.

\section{Common from Boston northward; Northern Europe.}

The most easily recognized species of the genus with us. It grows in deep tidepools, attached to pebbles and rocks. The filaments can be recognized at a distance by their dark glaucous-green color and rigidity. It is generally a foot or more in length, and the filaments are usually free, but become more or less twisted together. It does not adhere well to paper in drying, and in spite of its coarseness it does not bear immersion in fresh water.

C. AlRea, (Dillw.) Kütz. (Conferva area, Phyc. Brit., Pl. 99 b.)

Filaments erect, base scutate, setaceous, Jellowish green, cells $.25-40^{\mathrm{mm}}$ long by $.15-30^{\mathrm{mm}}$ broad.

In high-tide pools.

New York Harbor, Harvey; New Haven, Prof. Eaton; Newport, Bailey; Gloucester; Europe.

This species has a wider range than the last, being found not only in the north of Europe, but also in the Mediterranean and other warm seas. With us it is not un- 
common in Lone l-land somml, but is little hoown north of Cape coul. It grows in pools, sometimes near high-water mark, and resembles in habit $f$. melegonium, from which it defters in color, in lueing much less rigrid, and in the smallerese of its cerlls. As foume on our coast, the filaments are rather more slenter than the aserage of European specimens.

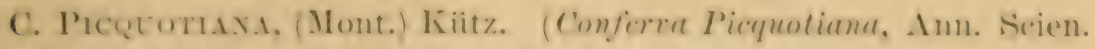
Xat., 3il ser. Vol. XI, p. Gti.-Chertomorpha P'iquotiana. Ner. Am. Bor., Part III, p. SJ, Pl. 46 c.)

Filaments prostrate, intricately twistenl together in masses, rigid,

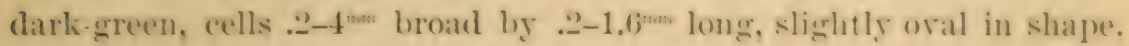

Deep water, and washed ashore.

Rather common from Boston northward; Staten Island, Mareey; Gay Head, Mass.

This species was first described ly Montagne from specimens colleceted by Lamarel'iepuet in Labrablor. It is the largest of our prostrate Chertomorquhe, and north of lissten is not uncommon on beaches after a storm, but it has not been seen in tide-pools. The localities south of Cape Cod perhaps need revision. We have found the sprecies washed ashore at (iay Head, from deep water. It reminds one of $C$. melagonium br its color, rigidity, and size of the filaments, and it seems to us probable that it is merely an advanced stage of that species which has broken from its attachments aud become entaugled without having lost its power of growth. It is certainly very unlikely that any alga of this suborder is throughout its whole period of existence unattached. The cells differ from those of $C$. melagonium in being sometimess several times longer than broad, lut, on the other hand, they frequently are found no longer than broad. If the species is really distinct and not an older stage of $C$. melagonium, as we suspect, it is the largest and coarsest of our speeies, and is to be comprared with C. toruluxa, Zan, of which we have examined specimens collected by Inauck at Pirano, in the Adriatic. In drying, our species does not adhere to paper, and the cells coutract at the joints so as to give a toruloid appearance.

C. Lrvur, (Flor. Dan.) Kïtz. (Conferra Limum, Crouan, Algues Marines du Finistìre, Yo. 353.-Conferta Linum, Areschoug, Alg. Scand., Yo. 183._Chatomorpha herbacea, Kiitz., in Hohenacker's Meeralgen, No. 355.-Chatomorpha Linum, Küitz., Spec. Alg., p. 37S._Chatomorpha sutoria, (Berk.) Harv., Yer. Am. Bor., Part 3, p. 87.-Non Conferra Linum, Alg. Danmon., Yo. 220, nec Rhizoclonium Linum, IIerb. Thuret.)

Filaments prostrate, intricately twisted together in masses, rigid, bright green, cells .20-2.5m broad by $.20-30^{\mathrm{mm}}$ long, about as broad as long.

Just below low-water mark.

Common in Long Island Sound; Xahant, Ten Pound Islant, Gloncester, Mass.; Europe.

The eronfusion which has ari-n from the application of the name Conferva Linum to different species and the useless multiplication of names, esperially on the part of Kitzing. rakes it exceedingly diffieult to ascertain the name of this common species on our coast. It forms strata of consilerable extent upou recks and gravel just below 
low-water mark. It can be distinguished from the preceding species by its lighter color, by being less rigid, and by the smaller size of the cells, which are rather uniformly as broad as long. If we may suspect that $C$. Picquotiana is only a form of $C$. melogonium, we may also suggest that the present is possibly the corresponding form of $C$. cerea. To unravel the synonymy of the species is quite hopeless. Our specimens agree with No. 353 of Crouan's Algues Marines du Finistère and No. 18.3 of Areschong's Algae Scandinaricie, both of which are supposed to be the Conferta Linum of the Flora Danica. They are also identical with No. 355 of Hohenacker's Meeralgen, which purports to have been determined as C. herbacea, Kig., by Kuitzing himself. Whether they are the same as the Conferva Linum of the Phycologia Brittanica we cannot determine. They approach very near to, if they are not identical with, $C$. crassa of the Italian algologists. In fact, Crouan considers C. Limum, Fl. Dan., to be the same as C. crassa, Ag. The Chretomorpha sutoria of the Nereis Am. Bor. seems to us the same thing. We have examined Bailey's specimens, from which Harvey named the species in the Nereis, and have also examined Bailey's locality, at Stonington. To the naked eye, in Bailey's specimens, the filaments appear smaller than the typical form, but a microscopic examination gives the same measurements as specimens we collected ourselves, which agreed precisely with No. 35i3, Cronan. In saying that the New England specimens of $C$. sutoria should be considered to be rather $C$. Limum, we do not mean to imply that the European $C$. sutoria is not distinct. Whether our species is the same as Rhizoclonium Linum, Thuret, is, perhaps, doubtful. In specimens of the last-named species from Cherbourg the filannents appear to be somewhat smaller. The species usually, but not always, loses its color drying, and scarcely arlheres to paper unless under considerable pressure.

\section{SPECIES INQUIRENDAE.}

C. Olneyi, Harv., Ner. Am. Bor., Part III, p. 86, Pl. 46 d.

"Filaments tufted, setaceous, straight or curred, soft, pale green; articulations once and a half as long as broad." (Harres, l. c.)

Rhode Island, Olney.

C. Longiarticulata, Harr., Ner. Am. Bor., Part III, p. 86, Pl. 46 e.

"Filaments capillary, curred, loosely bundled together, flaccid, soft, pale green; articulations 4-6 times as long as broad, swollen at the nodes ; var. $\beta$, crassior, filaments more robust." (Harrey, l. c.)

In rock-pools, between tide-marks. Ship Anne Point, Mr. Hooper; Boston Bay, Mrs. Asa Gray; Little Compton, IIr. Olney; rar. $\beta$ in brackish ditches at Little Compton, Mr. Olney.

The two last species are only known from the descriptions in the Nereis. No authentic specimens exist in the Olney Herbarium, which is now the property of Brown University. The specimen of C. Olncyi mentioned in Alge Rhodiacea by Olney was determined by the present writer, not by Harrey himself, and a recent examination of the specimen, for which we are indebted to the kindness of Professor Bailey, lead us to think that the specimen was not correctly determined.

\section{RHIZOCLONIUM, Kiitz.}

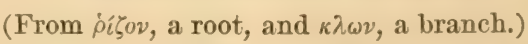

\section{Filaments decumbent, entangled, branches short and root-like.}

The genus is easily recognized, as a rule, by the root-like character of the branches. In some species the branches are frequent; in others, however, they are only occa- 
sionally fouml, and in that case the speeies may masily he mi-faken for spercies of Chatumurpha.

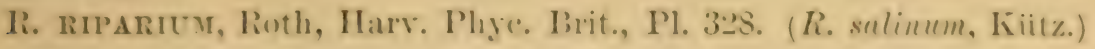

Filaments decumbent, pale green, forming entangled masses, furnished with numerous short root-like hranehes, generally consisting of

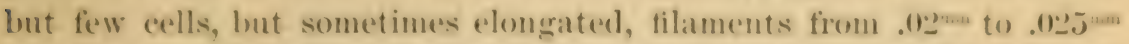
in diameter, cells about as long as broat, or a little longer. PI. III, Fig. 2.

Eastport, Maine; Nahant, Wood's Holl, Mass., Wr. G. F.; Xew Haven, Conn., Prof. D. C. Eaton; Europe.

An alea which is probably eommon all alonge the conat on wool-work and sandy rocks lwetween tide-narks. It forms thin light-green masses on the sulnstance on which it is grow ing. The ront-like processes usually consint of not more than three or four eells, amb unt unfremuently they fork. Distinguished at sight from the next ly it yellowish color. It often covers the gromed at the base of spartina, and it is fomml mearer high-water mark than the next species.

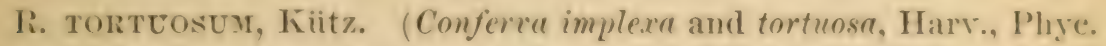
Brit., Pl. it a and b.-Chatomorpha tortuosa, Yer. Am. Bor.)

Filaments dark green, very much curled and twisted, forming prostrate masses, diameter of filaments, .03.5m to .0.5 $5^{\mathrm{mm}}$, cells about twice as long as broad, branches few, short.

Common all along the New England coast; Europe.

The most common species of our coast, recognized ly its dark-green color, and by the rery much twisted tilaments which form woolly st rata over other algae. Its fatrorite habitat is in tide-pools, where it is exposed at dead low water.

R. Kocmastru, Kiitz. (Conferra arenosa, Cronan, Algues Marines du Finistire, No. 355.-Conferra implexa, var., Alg. Scand., No. 15i.Khizoclonium Kochianum, Kiitz, in Le Jolis's Liste des Algues Marines de Cherbourg.)

Filaments pale yellow, forming loose masses of indefinite extent, cells $.010-14^{\text {mum }}$ broad by .036-5 $4^{\mathrm{mm}}$ long.

On alga below low-water mark. Summer.

Gloncester, Mass.; Nahant, Mass., Mr. Collins; Europe.

Much finer than any of the species previonsly mentioned, eovering al gar with a delicafte pale-yellow fleece. It is apparently less common than our of her two speries, and we have only foutud it once growing over Lamimario just loelow low-water mark, oft' Viles's Boarh, Gloncester. The species agrees with French specimens of R. Rochianum in the size and general appearance of the cells, lut the root-like proeesses characterjstie of the present genus are nut evident in our specimens, and the speecies is here retained in Rhizurlomum on the authority of Kiitzing, in Le Jolis's Liste des Alerues Mat-

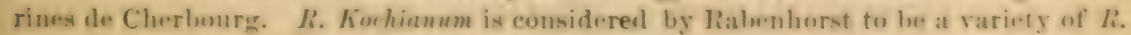
fluricans, Jiirg., in which he also includes Conferva arenicola of Berk. (Jur speecimens agree perfectly with No, 355 of Crouan's dlgues Marine du Finisti-re. lut are rather mualler than No. 1-7 of A reschong's Alga Seandinavieas, whieh is refiereed w ith doulut to Conferra arenosa. The name whieh we have adepted refers our speeimens withont dembe to French forms, lut the identity with the gerenuine C. arenexa of British lowan- 
ists still remains to be settled. The species does not adhere well to paper, and would probably, at first sight, be referred by collectors to Chatomorpha rather than to Rhizoclonium.

\section{CLADOPHORA, Kütz.}

(From $\kappa \lambda x \delta o s$, a branch, and $\phi \circ \rho \varepsilon \omega$, to bear.)

Filaments firm, not gelatinous, branching throughout.

A genus including the greater part of the branching Chlorosporea, which are found both in salt and fresh water. It differs from Ulothrix and Chetomorpha in having branching filaments, and from Rhizoclonium in having well-developed branches and not mere rhizoidal growths. The species abound on rocks and in tide-pools, as well as in ditches and shallow bays along the shore, and usually grow in tufts. Some of the species, however, especially those growing in brackish ditches, at maturity form dense layers upon the surface of the water or on the bottom. The number of described species of the genus is immense, but, in all probability, a great part are not distinct. It is at present impossible correctly to refer the New England species to European forms, since European botanists by no means agree as to their own species, and there has been a tendancy on the part of algologists of different countries to ignore the species of other countries in studying their own. The principal specific character is the mode of branching, which, in the present genus, is at best an uncertain mark. The young and old plants of the same species often differ very much in the appearance of the branches, so that the habit varies at different seasons. When old, some species are usually torn from their attachments and washed ashore in large masses, and, in this battered condition, it is often impossible to recognize the species, or perhaps even to distinguish the specimens from Rhizoclonium species. Unfortunately, names have been given to the battered forms until there is such a labyrinth of synonyms that one is tempted to reject all but a few well-marked species. In the present instance we have attempted merely to compare our specimens with those in the Algæ Danmonienses, the Algues Marines du Finistère, the Algæ Scandinavicæ of Areschoug, and with specimens received from Dr. Bornet, M. Le Jolis, Dr. Kjellman, and Dr. Wittrock. It is to be hoped that some responsible algologist will undertake the revision of this much-abused genus.

Subgenus SPONGOMORPHA, Kütz.

Plants spongy, at least towards the base, owing to the interlacing of the branches, some of which are strongly recurved and rhizoidal.

C. ARcta, (Dillw.). (Cladophora arcta, Phye. Brit., Pl. 135.)

Filaments slender, two to eight inches long, tufted and densely matted at base, becoming free and divergent above, color a bright green; branches near the base strongly recurved and interlaced, upper branches erect or appressed, numerous, opposite or scattered, apices obtuse; cells at base about twice as long as broad, cells of upper portion several times longer than broad, average diameter of cells about $.08^{\mathrm{mm}}$.

On rocks between tide-marks. Winter and spring.

Common along the whole coast; Europe.

One of the few species which are recognized without difficulty, although it varies considerably in aspect at different seasons. When young the filaments are but slightly matter together, except at the very base, and the species is then the $C$. vaucherioformis 
of Agarilh: hut when old they become spongry nearly to the tip, and coustitute the $R$. centralie of some anthors. The species is, as a role, easily distinguished by its brightgreen color and ereet or appressed braneles in the upper pertion of the plant. Tho plaut preserres its beantiful green color, and adheres to paper execpt when very old and spongy.

C. I.Axoss, (lioth) Kiitz. (C. lanosa. Plı̣e. Isrit., Pl. (i.)

Tufts more or less globose: filaments one to three incines long, densely matterl, color at first hright green, hut soon hecoming pale yellow; bramelıs long, numeroms, irregularly placed, often secumb, given off at

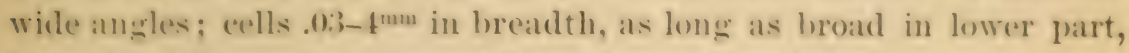
leeroming in upere part sereral times longer than loroad.

On Chondrus crispus and other algæ.

Gluncester, Xahant, Mass.; common, Europe. Sipring and early summer.

Var. uxcıu.s, Thuret. (C'l. uncialis, Marv., Phye. Brit., P'l. 207.)

Filaments longer and looser than in the type, and of a lighter color.

On sandy rocks.

Long Island Sound; Nahant and Gloucester, Mass.; common. Spring. Europe.

An easily recognized species, probably common along the whole coast in spring and early summer. It grows attached to sea-weods or to sand-covered rocks at low tides and below, and is often washed ashore in considerable quantities. It forms grolose tnfts, which, when growing, are bright green, but which soon lose their color, and, on drying, became pale and silky. The var, unciulis, which is more common in Long Island sound, is less dense and forms looser tufts than the type. It does not adhero very well to paper.

\section{StBGEXUS ELCLADOPHORA.}

Plants tufted, or, at times, stratose, not united into spongy masses by rhizoidal branches or recurved branches.

C. Rtupestris, (Linn.) Kiitz., Phye. Brit., Pl. 180.

Filaments five to ten inches long, rigid, dark green, tufted; branches cowderl. usually opposite or in fours, ultimate branches given ofi at an arute angle, short, subulate; cells constricted at the joints, arerage diameter of cells $.08-16 \mathrm{~mm}$.

On rocks near low.water mark.

Common along the whole coast throughout the year; Europer.

linoosnized by its datk green color and rigility, and by the numerous appressecel ramuli which are given off two or three at a joint.

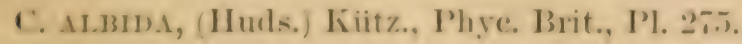

rilaments slender, silliy, forming dense tufts from a few inches to a fout long. color a pale green; branches irregular, often opposite, ulti- 
mate branches long, given off at wide angles; cells .02-3 $3^{\mathrm{mm}}$ in cliameter, cell-wall delicate, terminal cells blunt.

Staten Island, Beesley's Point, New York Bay, Harrey; in pools, Newport, R. I.; Europe. Summer.

Not yet observed north of Cape Cod. The species is recognized by forming dense tufts of a pale color and almost spongy consistency. The sponginess, howerer, is not, as in the subgenus spongomorpha, due to the interlacing of short recurved branches and rhizoidal filaments, but to the fineness of the filaments, which are densely twisted together. The cells do not vary much in diameter thronghout. This species, when dried, loses most of its color, and does not adhere well to paper.

C. REFracta, (Roth) Areschoug. (Non C. refracta, Alg. Danmon., No. 228, nee Phyc. Brit., Pl. 24.)

Filaments rather rigid, forming tufts from 2-8 inches long, color a glaucous green; branches flexuous, clothed throughout with nearly equal, short, frequently opposite branchlets, which are at first patent and furnished with erect or corymbose, afterwards reflexed, branchlets; cells $.03-8^{\mathrm{mm}}$ in diameter, terminal cells blunt.

Common in deep tide-pools and on stones and sea-weeds at low-water mark throughout our limits. Spring and summer. Northern Europe.

We have refrained from quoting any synonyms in the description just given. The species, as we understand it, is one common in rocky places where the water is pure. It forms rather short tufts of a somewhat glaucous green, which is paler when the plant grows exposed to the sun. The branchlets, which are in general short, are at first erect, but, as usually found, are somerhat corymbose and ultimately decompound and reflexed. It is rather rigid and does not collapse when removed from the water. In drying it sometimes retains its color, but usually becomes yellowish and does not adhere well to paper. What we have described seems to be the C. refracta of Harves's Nereis, but we have refrained from quoting the localities given by Harrey. The $C$. refracta of the French coast is considered by Le Jolis to be a rariety of $C$. albida. The same is not true of our species, which is certainly distinct from $C$. albida. It may be that we have also the refracted variety of $C$. albida on our coast, but we have never met with it. The present species is much coarser and differs in habit and ramification from the $C$. albida of New England, which agrees well with European specimens. The American C. refracta is much nearer to, if not identical with, the species published by Areschoug in the Algæ Scandinavicæ, $2 d$ series, No. 338, as C. refracta, (Roth). In coarseness it approaches C. laterirens, but it certainly is not the same as No. 143, Algæ Danmonienses, which Harrey considers to be C. laterirens. In short, we think that the $C$. refracta of New England is not the species to which the French botanists apply that name, but probably the species of Areschoug. Whether it is really the Conferca refracta of Roth is a point on which we can only follow the authority of others. At any rate, after the explanation given, the name can be retained without causing greater confusion than has hitherto existed.

C. Gladcescens, (Griff.) Harv. (Cl.glaucescens, Phyc. Brit., Pl. 196.cl. pseudo-sericea, Crouan, Alg. Finist., No. 367.)

Filaments loosely tufted, 3-12 inches long, much branched, color light green; branches erect, pectinate, ultimate branchlets elongated, erect, 


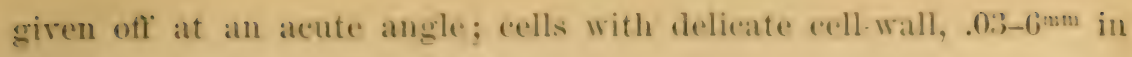
diameter, terminal cells aeute.

On stones and wood-work near low-water mark. Summer.

From Halifax, X. S., to Charleston, S. C., Hurrey: Newport, R. I. ; Europe.

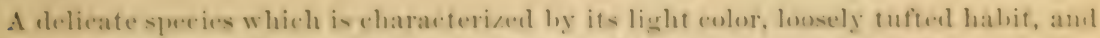
slemler bramehes, which are all given oft at uniformly acute angles. When growing

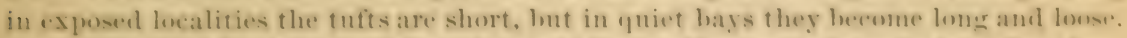
This-pueies, which has the light color aud slemeler filaments of $r$. alliela, differs from that speeies in not being spongy in consistrnee and in the length of the ultimate brambleles, which are always erect. Our Newport species resemble rery chosely the

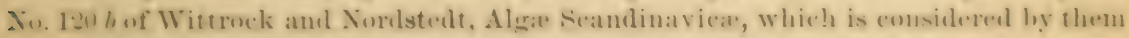
a firm of $r$. crystullime, (lioth), hut differs from the (\%. crystullina of the algologists

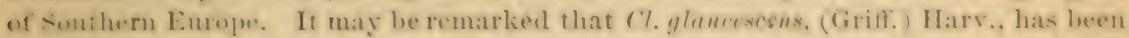

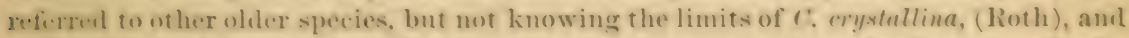

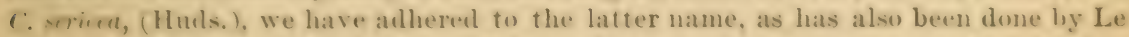
Julis amb other French algulogists. This species gunerally becomes very pale in drying and alheres well to paper.

The variety 3 , pectimella, of this species, mentimed by Marvey in the Nereis Am. Inor. as ocenring in Charleston Harbor, is not huown on our northern coast. In the variety the branches are said to be recurved.

C. L.etevinexs, (Dillw.) Harr., Alg. Dammon., No. 142; Phỵe. Brit., P1. 190.

Filaments much branched, rigicl. forming loose tufts 3-6 inches long, color a yellowish green; hranches fastigiate, erect, often opposite or in threes, ultimate branchess secund, of few cells, apex olstuse; diameter of cells $.05-.15^{\mathrm{mm}}$.

In tide-pools.

Xew York Bay; Boston, Harey; Gloncester, Mass, Mrs Daris.

A rather molust speries, recongized by the denseness of the hranches, which are crowded at the tips. Less robust and differing from C. Mutehinsie in having fastieriate liram los. We have only seen one specimen, collected hy Mrs. Davis, which correpmoled exactly to the C. laterirens of Algae Dasmonienses and to the C. laterirens of the X.re is Am. Bor. It is douletful whether the forms to which the same name has laen given by French botanists belong to the same speries as our own. Fume of them, at lan-t, apluar to helong to a more slemeler and less densely branching species. The species does not adhere well to paper in drying.

C. Hetchasis, (1)illw.) Kiitz. (Cl. Mutchinsie, Plyge. Brit., Pl. 121._Cl. diffusa, Harr., Phye. Brit., Pl. 130.)

Filanents rigid, gliucous green, flexuous, forming loose tnfts 6-12 inches long; hranches smattered, rather distant; ultimate hranches few, short, secrund; cells .10-21 $4^{\mathrm{mm}}$ in diameter.

In tide-pools.

\section{Gloucester, Mass., Mrs. Davis.}

A single specimen which sems ummistakialy to belong to this species was collected hy Mrs. Davis. The speeine, whirh is one of the coarsest on the coast, is distinguished 
by the large size of the filaments and remoteness of the branches, together with the shortness of the ultimate brauches. The Cladophora diffusa of the Phycologia Brittanica is now considered, with good reason, to be a form of C. Hutchinsice in which the branches are very long and nearly destitute of branchlets. Probably the Cladophora diffusa? of the Nereis Am. Bor., said by Harvey to be found in "Xew York Sound," is to he referred to the present species. Specimens which correspond well enough to the $C$. diffusu of the Algie Danmonienses, No. 14t, have been collected by Mrs. Davis and Mrs. Bray at Gloucester.

C. Flexuosa, (Griff.) Harr.

"Filaments very sleuder, pale green, tufted, flexuous, sparingly and distantly brancher ; branches elongate, subsimple, of unequal length, flexuous, sometimes nearly naked, sometimes ramuliferous; the ultimate ramuli secuud or alteruate, short or long, curved; articulations of the brauches $3-4$ times, of the ramuli trice as long as broad." (Nereis Am. Bor., Part III; p. 78.)

Rocks between tide-marks, \&c.

Hingham and Boston, Mass.; Jackson Ferry and Heli Gate, N. Y.

We hare quoted from the Nereis Am. Bor, the description given by Harrey of the present species, and have purposely refrained from adding any localities of our omn. Harvey considers $C$. flexuosa very nearly related to $C \%$ glaucescens, if indeed it is distinct from it. On the other hand, the greater part of the Frencle specimens of $C$. flexuosa which we have seen are quite distinct from $C$. glaucescens, and seem to approach some of the forms of $C$.gracilis. We have frequently seen at Wood's Holl, Nemport, and Gloncester specimens which correspond pretty well with the C. Alexuosa of Alg. Danmon., No. 22\%. As we understand the species, it is more rigid than Cl. glaucescens, and has shorter branches, which are at times refracted. The cells are $.02-6 \mathrm{~mm}$ in diameter and not more than two or three times as long as broad as a rule. Le Jolis states that $C$. flexuosa lines the bottom of pools. The American forms which we would refer to this species are found in pools on rather exposed rocky shores.

C. Morrisize, Harr.

"Tufts elongate, dense, somewhat interworen, dark green ; filaments rery slender, much and irregularly branched; the penultimate branches very long, filiform, flexuous, simple, set with alteruate or secund, short, erecto-patent ramuli, some of which are simple and spine-like, others pectinated on their upper side; articulations filled with dense endochrome, in the branches $2-3$ times, in the ramuli about twice as long as broad, cylindrical, not contracted at the nodes." (Harres, Nereis Am. Bor., Part III, p. 79, Pl. 45 b.)

Elsinborough, Del., Miss Morris.

We only know this species from the description and plate of Harvey.

C. Rudolphiana, Ag.

Filaments rery long and gelatinous, forming loose tufts one or two feet long, color yellowish green; branches opposite or irregular, rery long and flexuous, given off at wide angles, clothed with long, secund, 
tapering bramchlets; cells .0:-5mm in diameter, those of the man lranches many times longer than broad.

On stones and covering alga just below low-water mark. Summer. Jackison Forry, X. X., Harey ; Wood's Holl, Mass.; Europe.

One of the longers lut at the same time ment delisate of the gemus. It forme in-

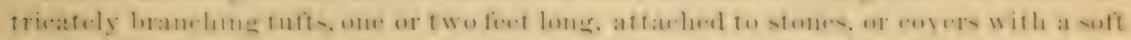

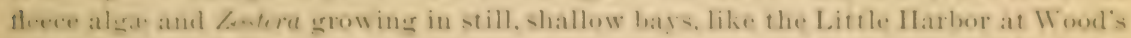

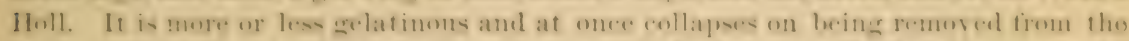

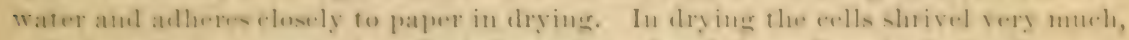

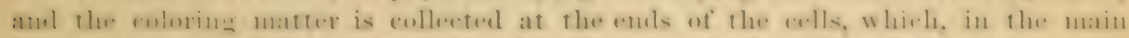

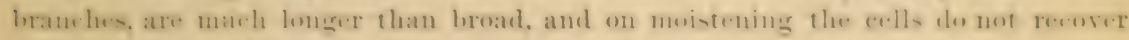
their shape as readily as in other species.

C. Gracilis, (Griff.) Kütz.

Filaments lousely tufted, i-12 inches long. imegularly bent, movided at the angles with rather short hanches, which are peetinate, with long recurved or inemved hranchlets: color a yellowish green; cells .04-16 in diameter.

On wharves or in muddy pools.

New Haven, Prof. Eaton; Wood's Holl, Mass.

a. Var, ExpAxs

Very irregularly branched. forming masses one to two feet in extent. Muddy pools.

3. Gloucester, Nahant, Mass.

Var. Textis, Thuret. (Cl. vadorum, Aresch.)

Inanches remute, filaments more slemiler than in the tỵe, $01-5^{\mathrm{mm}}$ in liameter.

Growing over Laminaria.

Gloncester. ?

A commen and sariable species. growing in rather muldy sheltered places and not

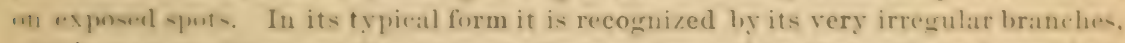
which are mow divergent than in mont ot her speries, and ly its pertinate hranelilets. whelh are at times tlabellate. The speries, although rather delicate in sulutanee, is

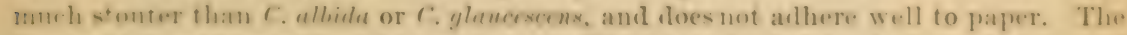
furm which we have refierred to, var, tenuis, Thuret, is doubtful. It formel un:ases of

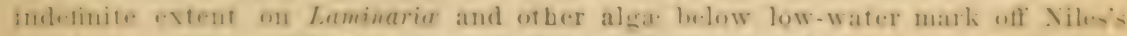

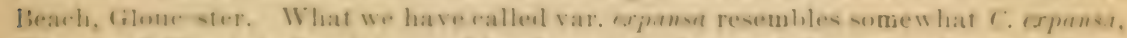

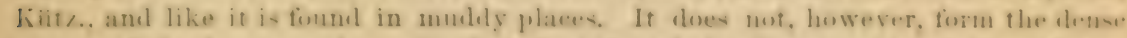
mases of the las-named speries. lnt floats loosely in the water in shallow places. The ordinary forms of the speries are recosnised without mueh diffiralty, lut one

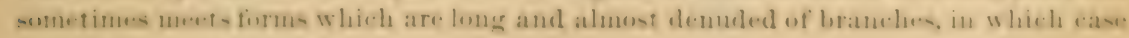
d. tr.mination is diflicult.

\section{U. EXPANsA, Kiitz.}

Filaments of a dull-green eolor, at first tuted, then matted together, forming extrosive strata; main branches irregularly flexuons, .10-1.5m 
in diameter, clothed with secondary branches, which are divaricately divided and furnished with secund ultimate branches; cells several times longer than broad.

In brackish ditches. Summer.

Wood's Holl; Malden, Mass.

To the present species may be referred the greater part of the New England specimens of brackish water referred to C. fracta. It is at first tufted, but soon rises to the top of shallow ditches and cores, and forms an intricately interwoven mass. It is distinguished from $C$. fracta by the greater size of the main branches and the fact that the diameter of the secondary branches is always much less than that of the main branches, whereas in the true $C$. fracta the branches gradually diminish in size. In some specimens the branches are clothed at intervals with very short fasciculated ramuli. The species when in its tufted condition resembles some of the forms of $C$. gracilis. It also approaches the C. fracta of the Algie Danmonienses, said by Harrey to be rather $C$. flavescens.

C. Fracta, (Fl. Dan.) Kütz.

"Tufts irregular, entangled, often detached, and then forming floating strata, dull green; filaments rather rigid, distantly branched, the lesser branches somewhat dichotomous, spreading, with rexy wide axils; the ramuli few, alternate or secund; articulations 3-6 times as long as broad, at first cylindrical, then elliptical, with contracted nodes." (Uarvey, Nereis Am. Bor., Part III, p. 83.)

Salt-water ditches and ponds.

West Point, Prof. Bailey; Beesley's Point, Ashmead; New York, Walters; Baltimore, Md.

Wre have quoted from the Nereis the description given by Harrey. It is doubtful whether under the name $C$. fracta he referred to the species of that name as recognized by Scandinarian botanists. The only marine locality of this species which we have examined is in the vieinity of the Marine Hospital, Baltimore. As we understand the species, it is much finer than C. expansa, the cells being from .02-8mm in diameter, those of the main branches tapering gradually into those of the secondary branches, while in the last-named species the transition is sudden. The branches are less numerons and more irregular in their mode of branching in C. fracta than in C. expansa.

\section{MAGd Llen Ae, Harv., Phye. Brit., Pl. 335 a .}

Filanents one to three inches long, decumbent, entangled, coarse, blackish green; branches given off at obtuse angles, flexuous, with very few cures, irregularly-placed branchlets; cells .04-8m in diamter, about 2-4 times as long as broad.

\section{Napatree Point, R. I., Prof. Eaton.}

This rather unsightly and insignificant species is recognized by its procumbent habit aud dingy green color, and by having but few branches, which are arranged without any definite order, and are given off at very obtuse angles from the main filaments. It may be doulsted whether the species is not a reduced form of some other. 


\section{BULBOCOLEOx, Pringsh.}

(From $\beta 0$ \%; $30 s$, a bulb, and кoneov, a sheath.)

Filaments branching, ereeping, composed of two kimls of cells, one producing numerous zoospores, the other buhous at the base but drawn out into a tuhe, from the open extremity of which projects a long llexible Latir.

This geans, comsis: ing of a single species, was first deseribed by Pringshein in the Ahhandlungen der kïnigl. Akatemie der Wissensehaften, Berlin, 1-tis, who fommled it upon a small alga parasitie in the fromels of Leathesiu and other Phoresperee, at Helgoland.

The gronas resembles Coleochate, a fresh-water grous, in the strueture of the hairs. hut in Bulbocoleon no reproduetive bodies, exeppt zoospores produced in the ordinary colls, have as jet been discovered. It is not impossible that oospores maly at some time be fomml, and it will then be necessary to remove the genus from the present orter.

B. PILIferum, Pringsheim, 1. c., p. 8, Pl. I.

Characters same as those of the genus.

Parasitic in the fronds of Leathesia tuberiformis and Chorduria diraricata. Summer.

Jewport, R. I.; Wood's Holl, Gloucester, Mass.; Europe.

This minute species is found crepping anong the cortieal colls of Leuthesia and Chorderia, gemerally in complny with a streblomema. It forms dark spots on the fombls, and, on microseopic examination, the hyalune hairs are seen projecting above 1he surface. The spereies is studied with diffienlty when parasitic on Lathesiu, owing to the demsity of the cortical part of the fromd, lut is more easily examined when it grows on Chomlerie. It was found by Pringsheim on Chorda filum, Chorderia flagelli-

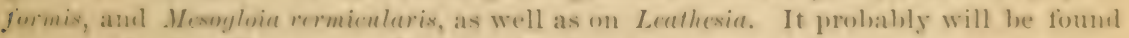

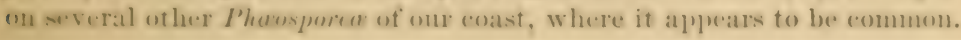

The following genns described hy lieinseh, including a species of which we have

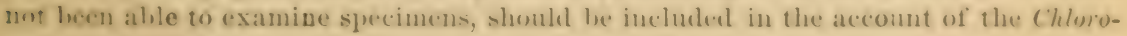
sporece of our coast :

Acroвlaste, new genus of Chroolepidea.

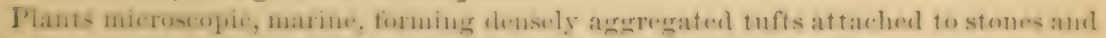

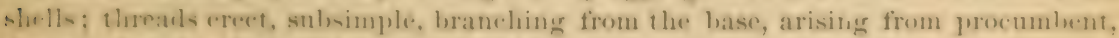
densely interlaced threads; conceptacles in the upper part of the branches nearly splucrical, at first muicellular, afterwards procheing $20-35$ spherical zouspores : after

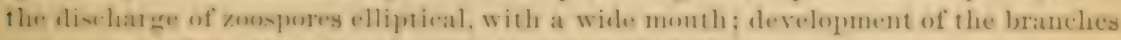
and growth of the threats as in Chronlepus and Cladophora.

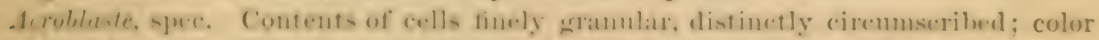

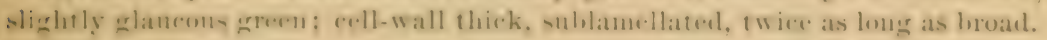

Height of plant, .336-. $6 \mathrm{~mm}$.

Diameter of filameuts, .0050-80mm.

Jianter of conceptacles, .0168-196mm.

11:aun-tier of zoospores, .002:mm.

IIel. - Attached to shells and stones, Buzzard's Bay, Muss.

Iirinsch., in Botauische Zeitung, 1879, No. 23, Pl. 3 a. 


\section{Suborder BOTRYDIE}

Fronds minute green unicellar, spherical or pyriform, with a rhizoidal process at the base. Globose bodies produced in the cells, from which, when discharged, there is formed a large number of zoospores, with two cilia, which conjugate.

A small suborder, of which the development is known only in a single species, $B$. gramulatum, of which Rostafinski and Woronin have given a full account. Probably the suborder may require to be united with the Siphonea, a group abundant in tho tropics, but not strictly found with us.

\section{CODIOLUM, A. Br.}

(Named from the resemblance to species of Codium, a genus of marine algæ.)

Frond unicellular, at the base prolonged into a tapering, solid, hyaline stalk, above clavate, containing an oval chloropyllaceous mass, which ultimately is transformed into a large number of spores, development of spores unknown.

The present genus was founded by A. Braun on a species found by him at Helgoland in $185 \%$ and described and figured in his trork on unicellular algie. A second species (C. Nordenskioldianum) was deseribed by Kjellman.

The genus is placed by Braun and Kjellman near C'haracium, but until the development of the spores has been made out the position of the genus must remaiu doubtful. Braun compares the spores to those of Codium, but states that he had never seen cilia. In American specimens we have never seen the spores escape from the mother cell and swim about by means of cilia, but, on the other haud, the wall of the nother cell dissolves and the spores thus set free begin to grow at once. It often happens that the spores begin to grow inside the mother cell. The spores are oval and have a thick wall. Each spore either gives off a projection at one eud, which grows into a long stalk, or else the contents of the spore become divided into a small uumber of cells by means of cross-partitions at right augles to its longer axis, thus forming a short filament, each cell of which gives off a stalk as previons!y described. There results in the last case a dense cluster of individuals, which adhere together by their bases. It may be that what we have seen was only the hypnosporic coudition of the plant, and that Bram had examined a stage in which motile spores existed. Occasionally one finds two spore-bearing cells on a single stalk, one always being rery much smaller than the other. The second cell is lateral and may be nearly sessile on the stalk or furnished with a short secondary stalk of its own.

Our plant recalls the hypuosporic condition of Botrydium granulatum, and in the Algæ Am. Bor. Exs. it was distributed under the name of $B$. gregarium. As the development is so little known, we have now thought best to retain the name Codiolum, on the supposition that our species is the same as that of Bramn. The study of the development is rendered difficult because the plant grows inextricably entangled with other small algæ.

C. Gregarium, A. Br. (C. gregarium, Braun, Alg. Unicell., Genera nova et minus cognita, 1. 20, Pl.1.-Botrydium gregarium, Farlow, in Alg. Am. Bor. Exs., No. 99.)

Cells densely aggregated, average length of cells, including stalk, 


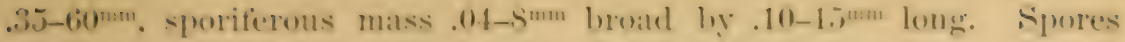
$.015^{\mathrm{man}}$ by $0.00 \mathrm{man}$.

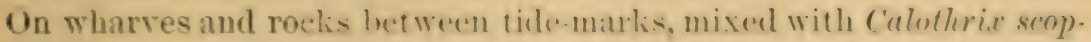
ulorum and Ulothrix.

\section{Eastport, Me.; Gloncester, Mass.; Europe.}

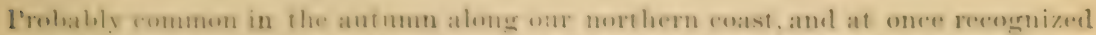
les the long terminal stalk. Which appeats to he an apperulage of the cell-wall. Thes

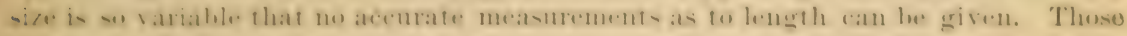
above stated represent the size of fully-grown sporiferons individuals.

\section{SEBORLR bli YOPSIDE.E.}

Frombs green, mieellar, filamentons, branching; reproduction by zoospores, with two cilia, tormed in the occhuled branches.

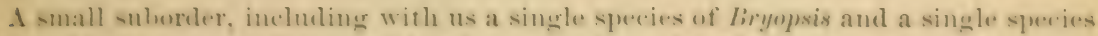

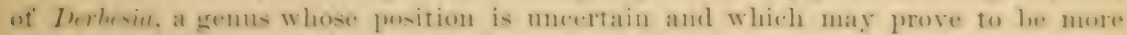

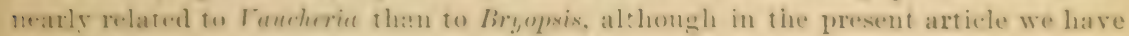
plarefl it with the latter.

\section{BRYOPSIS, Lam.}

(From 3pvor, a moss, and or't5, an appearance.)

Fromels bright green, unicellular, branching, usually pinnately divideal; reproduction in spores formed in oceluded portions of the branches: spores of two (?) kinds- (either green zoospores, furnished with two apical cilia, or orange-colored.

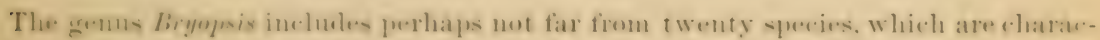
ferized lis the mente of hraneling. Most of them are pinnately compound, and the dititerent forms pass so gralually into one another that the species camot be said to

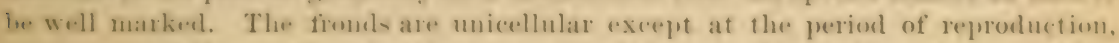
when some of the smaller loranches are separated ly partitions from the rest of the frond. The jumition of the gemus is still doulotful, as the development is not known. The reprobluctive bodies generally found are green zonspores which have two termiwal rilia. Whether they conjugate or not is not known, although as Thuret rejorts the oceursence of zom-peres with four cilia, sueh is probalily the case. A secomel form

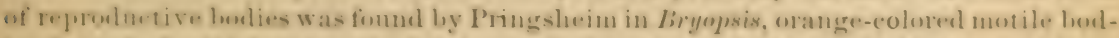
ies fumbleal with two trominal cilia. The derelopment of these bodies has not been

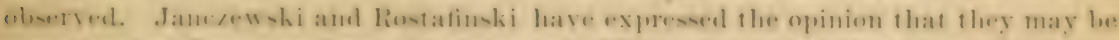
fara-ite- Int Conn contirms the statement of l'ring-he-iun that they are really organs of the Bryopsis.

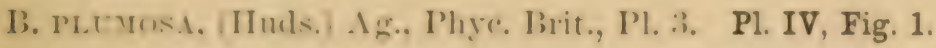

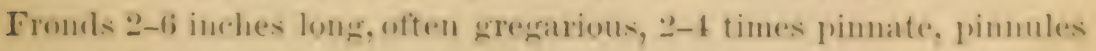
pramial in ontline, naked at the base, in the upler part clothed with short pinnnlie, which are constricted at base.

On muldy wharves and stones at low-water mark.

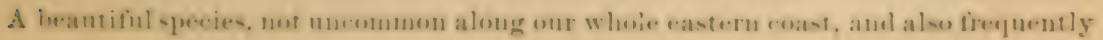


found on the shores of California. It is very widely diffused, being found in nearly all seas. B. hypnoides, which occurs at Key Wést, passes almost insensibly into $B$. plumosa, but the typical B. hypnoides is not known in New England.

\section{? DERBESIA, Sol.}

(Named in honor of Prof. Alphonse Derbes, of Marseilles.)

Fronds green, simple or slightly branching, unicellular, or sometimes with cross-partitions at the base of the branches; fructification consisting of ovoidal sporangia containing zoospores, which are of large size and have a hyaline papilla at one end, at the base of which is a circle of cilia; oospores unknown.

The genus Derbesia was founded by Solier on two Meriterranean species, $D$. marina and $D$. Lamourouxii. The position of the genus is doubtful. The Derbesice resemble in habit the more delicate species of Vaucheria and Bryopsis, and like them are often unicellular, but it is, however, not uncommon to find at the base of some of the sterile branches a short cell, separated by a wall both from the branch above and the main filament below. A similar cell is always present at the base of the sporangia, and the same cell is found in some species of Vaucheria. Derbesia differs from Bryopsis in having zoospores provided with a circle of cilia, borne around the base of a terminal hyaline papilla as in Edogonium. It differs from Vaucheria in not having oospores, so far as is known. The zoospores of Derbesia, according to Solier, germinate at once and are apparently of a non-sexual character, so that we may expect that hereafter either oospores or conjugating zoospores will be found. As we have said, the zoospores bear a striking resemblance to those of Edogonium, and perhaps the relationship to the last-named genus is closer than has usually been supposed. In this connection it should be mentioned that, in the formation of the cells sometimes found at the base of the branches, the cell-wall ruptures in the same way as in Edogonium, and if we do not have the same rings forming a cap at the end of the cells as in $O$ dogonium it may be because in Derbesia the formation of new cells is very limited.

D. tenuissima (De Not.), Crouan. (D. marina, Solier, Ann. Sci. Nat., 3 série, Vol. VII, 1). 158, Pl. 9, Figs. 1-17.-Bryopsis tenuissima, De Not., Fl. Capr.-D. tenuissima, Crouan, Florule du Finistère, non D. marina, Crouan, Algues Marines du Finistère, To. 398._Chlorodesmis vauchericeformis, Harr., Ner. Am. Bor., Part III, p. 30, Pl. 40 c.) Pl. IV, Fig. 4.

Filaments tufted, bright green, one to two inches long, $.04^{\mathrm{mm}}$ in diameter; branches few, erect, constricted, and often with a cuboidal cell at the base; sporangia on short branches, oroidal or pyriform, $.09-.12^{\mathrm{mm}}$ broad by $.20-.30^{\mathrm{mm}}$ long, resting on a cuboidal basal cell; spores large, few, about 15 in number.

Forming tufts on algæ.

Eel Pond Bridge, Wood's Holl, Mass.; Key West; Europe.

We have found this species but once on our coast, in May, 18r6. With us it is apparently rare, but the species is not uncommon in some parts of Europe, especially on the shores of the Mediterranean. Our form is very well developed and the sporangia are rather longer than in the European specimens which we have seen. 


\section{SUmorder PIIEOSPORE.}

lieproduction by means of olive-brown zoospores which have two laterally atta hed cilia ; sporangia of two kinds-milocular, containing a large number of zoospores, and plurilocular, compound sporangia, cach cell of which contains a single zoospore; conjugation of zoospores known in a few sprecies; marine plants, of an olive-brown color, whose fronds rary greatly in strueture, but which all auree in reproducing by zoospores.

A large igmup, first eorrectly defined by Thuret. Previous writers had regarded the semeture of the fromb to the exclusion of the organs of reproduction, and the speceies here incinded were placed in difterent orilers. In the Nereis they were placed partly

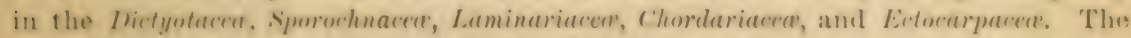
fonr last orders hatre been kejt as families, but the true bictyotacra are a dist inet order. All the olive-brown sett-weeds of New Enerland, except the rock-weeds, be-long to the present suberiler. In no order of plants do the spereies vary so widely in haldit as in the present. A large number, as the Eidocarpi, are filamentous and resemble in habit the Cladophore. The Laminario have expanded tlat fronds, and in Macrocystis and ligregiu, the most highly organized of the order, there are stems, distinet leaves, and air-blaclelers, and in Eigregin special fructiferous leatlets. Many of the species are of microseopic size, lut Macrocystix grows to be several hundred feet long.

\section{SPHENOSIPHON, Reinsch.}

(From $\sigma \phi \eta v$, a wedge, and $\sigma \iota \phi \omega \nu$, a tube.)

Fromils former of single cells placed side by side so as to form a more or less coherent mass : cells pyriform-cuneate or oblong-elliptical: contents of cells transformed into a number of very small spherical bodies (zoospores?).

In the Contributiones an Algologian et Fungologian, Reinseh places the genus Splumesiphon, of which he describes nine species, in the order Melanophycer. One of the species oecurs in fresh water and the rest are marine. They all form minnte spots on other algie, and consist simply of cellsplaced side loy side, the whole forming a thin membranous expansion. If the small bodies described and figured by Reinsch in the interior of the cells are really zonspores, anil if the cells themselves are olive-hrown, we must regard the genus. Sphernosiphon as tho lowest of the Phangorere. The development of the zorospures hats not been observed, and as Reinsch describes the color of some of the sprecies as bluish green and rose-colored, wo must consider the position of the irmus to be in donlut. Species of $S_{i}$ lhernosiphon are not unferguent on our coast, but they have not yet been sufhieiently stulied. Those which we have seen are more

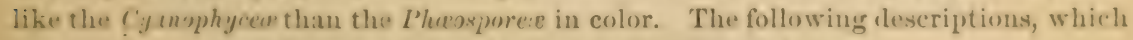
may apply to some of our species, are taken from Reinsch, 1. 6.

8. smaragdivus, Reinsch, 1. c., Pl, 35, Fig. 4.

Cells pyriform or broally cumeiform, munded at the apex, prolonged at the baso

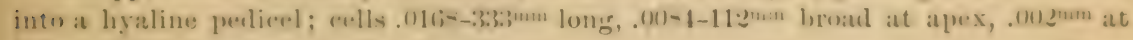
base; color bluish green; base hyaline.

On Plocamium coccineum, Labrador.

On Polysiphonia, Anticosti.

S. Olivacel's, Reinsch, 1. c., Pl. 36, Fig. $2 a$.

Cells pyriform or cumitiorm, broally rommlent at apex, contracted at bise; color olive-green; cells .013-24 $\mathrm{mm}$ long, breadth .0096-168mm.

On Ceramium rubrum, Anticosti and Labrador.

S. ROsEc8, Reiusch.

Cells broully ellipsoidal, plawed lowely towether, and surmumbed loy a thick hyaline

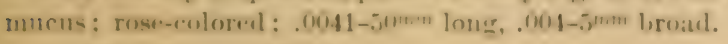

On zoophytes, Labractor. 
As an account of the families into which the suborder is divided has already been given on pp. 15-17, it is unnecessary to repeat them here, but the reader will find them briefly described in their order on subsequent pages, together with a synopsis of the genera found on our coast belonging to each family.

\section{FAMILY SCYTOSIPHONE E.}

Fronds unbranching, either membranous or tubular ; plurilocular sporangia in short filaments, densely covering the whole surface of the fronds ; unilocular sporangia not well known.

Fronds expanded membranes ...................... Phyllitis.

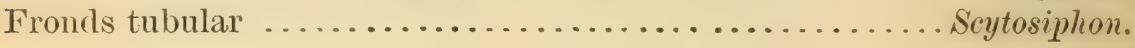

\section{PHYLLITIS, (Kütz.) Le Jolis.}

(From $\phi v \lambda \lambda_{\iota} \eta \varsigma$, a name given by Dioscorides to an unknown plant.)

Fronds olive-brown, simple, membranaceous, composed of a cortical layer of minute colored cells and an internal layer of larger, oblong, colorless cells, which are sometimes prolonged downwards in the form of short filaments; plurilocular sporangia formed from the cortical cells, covering the surface of the fronds, consisting of a few (4-6) cells arranged in short filaments, which are closely packed together at right angles to the surface of the fronds; unilocular sporangia and paraphyses unknown; growth from the base.

A genus consisting of two species, formerly placed in the genus Laminaria in consequence of their membranous habit, but differing essentially from the true Laminaria in the structure and disposition of their sporangia.

P. FASCIA, Kütz. (Laminaria fascia, Ag.)

Fronds gregarious from a disk-like base, three to six inches long, a quarter to half an inch wide, linear-elongate, contracted at the base into a short stipe.

Var. Cespitosa. (Phyllitis ccespitosa, Le Jolis, Etudes Phreol., p. 10, Pl. 4.-Laminaria caspitosa, Ag.-Laminaria fascia, Harr., in Phye. Brit., Pl. 45.-Laminaria debilis, Crouan, Alg. Finist., No. 81.) Pl. IV,

\section{Fig. 3.}

Fronds stipitate, cuneiform, often falcate and undulate.

Very common on stones between tide-marks; widely distributed over all parts of the world.

About the limits of the present species there is a diversity of opinion. Le Jolis regards the L. fascia and L. cospitosa of Agardh as distinct species, but by Harvey they were considered as merely different forms of the same species. Harrej's opinion seems to us to be correct, for it is impossible to draw the line between the two forms as found on our coast. 
SCITOSIPION, ( $\Lambda$ g.) Thuret.

(From $\sigma \kappa v т{ }^{\prime}$, a whip, and $\sigma \iota \phi \omega \nu$, a tube.)

Fromels simple, eylintrical, ustally constricted at intervals, hollow, cortex of small colored cells, inner layer of rertically elongated, colorless cells: sporangia as in Phyllitis; paraphyses single-celled, oblongrobovate, interspersed among the sporangiar.

The present genus is founded on the Chorda lomenturia of older writers. The genus siytosiphon, as proposed by Agardle, inchuled both C. Tomentaria and C. filum. The latter species, which is still kept in the genus Chorda hy most writers, has the surfaco of the froad covered with chub-shaped paraphyses, between which are situated the oval unilownlar sporangia. In $S$. lomenturius the bodies called paraphyses are only occasionally foumd, and their real nature is a little uneertain. Both Bornet and Areschong consider them to be paraphyses, and the latter has fienred them in Observa-

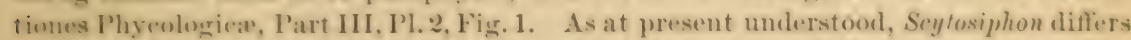
from Phyllitis only in the fact that the fromel is tulular instrad of mombranous, and in the presence of paraphyses, which have not yet been fouml in Phyllitis.

s. Lomextarius, Ag. (Chorda lomentaria, Lyngb.; Phyce. Brit., I'l. 25.;.-Chorda filum var. lomenturia, Iriitz., Spec. Alg.)

Fronds gregarious, three to eighteen inches long, attached by a disklike base, shortly stipitate, expanding into a hollow tube, from a quarter of an inch to an inch in diameter, at first cylindrical, afterwards constricted at intervals.

Very common on stones between tide-marks; found nearly all over the world.

A species easily reconnizel, exerpt when quite young. by its tubular and constricted froml, but chiefly interesting in conseyuence of the smaller species of algat which grow upon it. At Eistport a very large form is folanl, nearly a: inch in diameter, and much twisted.

\section{Family PUNCTARIEA.}

Fronds unbranching, forming expanded membranes or cylinders; fructification in spots (sori) on the surface of the fronds; plurilocular sporangia ellipsoidal, composerl of few cells; unilocular sporangia spheroidal.

\section{PUNCTARIA, Grev.}

(From punctum, a point, refierring to the dests formed by the sporangia and hairs.)

Fronds olive-brown, simple, membranaceous, attached by a discoidal base, composed of several (2Z-6) layers of cuboidal cells of ahout the same dimensions in all parts of the fronds; unilocular sprorangia immersed in the frond, collected in spots, spherical-cuboid, formenl from the superficial cells: plurilocular sporangiat collecterl in spots, immerserl ex. 
cept at the apex, formed from the superficial cells ; fronds covered with clusters of hairs; paraphyses wanting.

A small genus, containing probably not more than half a dlozen good species, which are widely diffused. In the Nereis Am. Bor. the genus is placed by Harvey in the Dictyotacer. That order is now restricted to a group, not represented, as far as is known, on the coast of New England, in which there are quiescent spores, tetraspores, and antheridia, but no zoospores, and Puncturia is evidently related to the Phacosporece, judging by its sporangia. Litosiphon pusillus, a small parasite on various algæ, is closely related to Punctaria, but differs in having a filamentous frond and more simple sporangia. It probably occurs on our coast, but has not yet been observed.

P. Latifolis, Grer.; Phyc. Brit., Pl. 8; Études Phycol., p.13, Pl. 5. Fronts pale olive-green, gregarious, shortly stipitate, lanceolate or oborate, four to twelre inches long, one to fire inches broad, substance tender.

Var. zoster a, Le Jol. (P. temuissima, Phyc. Brit., Pl. 248.)

Fronds thin, pale, lanceolate at both extremities, narrow, margin undulated.

On different algie at and below low-water mark. Spring and summer. Europe.

P. Plantaginea, (Roth) Grev.; Phyc. Brit., Pl.128. Pl. IV., Fig. 5.

Fronds deep brown, gregarious, broadly lanceolate, attenuated at base, one to three inches broad, three inches to a foot long, substance somewhat coriaceous.

Orient, L. I.; Point Judith, R. I., Olney; Wood's Holl, Gloucester, Mass.; Europe. Summer.

It is not altogether easy to distinguish our two species in some cases, although as a rule they are sufficiently distinct. $P$. latifolia is much the more delicate of the two, and has a greenish tinge. When in fruit it is punctate, the dots being the sori. Both forms of sporangia are often found simultaneously on the same frond. In P. plantaginea the frond is decidedly brown and rather coriaceous, and the punctate spots are caused by the dense clusters of hairs which are often found to correspond on both sides of the frond. Both species are common in spring and summer, and although often washed ashore in considerable quantities on exposed beaches, they prefer quiet bays.

\section{Family DESMARESTIEA.}

Fronds branching, cylindrical or compressed, with an axis of filaments composed of elongated cells and a cortex composed of spheroidal cells; unilocular sporangia formed by the direct transformation of the cortical cells; plurilocular sporangia unknown.

\section{DESMARESTIA, Lamx.}

(In honor of A. G. Desmarest, a French naturalist.)

Fronds olive-brown, solid, cylindrical or compressed, much branched, attached by a disk, cortical layer composed of small polygonal cells, 
Internal portion consisting of an axial filament formed of a single row of rather large cylindrical cells, surromuled by a mass of oblong cells sometimes mixed with smaller winding cells: in the spring fronds covered with branching hairs, which drop off later in the season; unilocular sporangia formed directy from the cortical cells, which do not umlergo any change in shape or size; growth trichothallic.

A s:mall gemns, consisting of abont fifteen described species, a considerable portion of which bear a close resemblanee to $I$ ). uculeatu. They are inhabitants of the colder semas in both the nurthern and sonthern hemispheres. Our two species are very widely diffiseul, but 1). liguluta, a common species of California as well as of Europe, is wanting on our eoast. The grenus is easily distinguished from its allies hy the axial filatment and the formation of the zoospores in the unchanged superficial cells.

D. Aculeata, Lamx., Phye. Brit., Pl. 49; Ner. Am. Bor., Vol. I, Pl. $4 b$.

Fronds dark olive-brown, one to six feet long, terete below, compressed above, naked at the base; branches alternate, numerous, long and virgate, lower branches longer than upper, several times pinnate, clothed in spring with hairs, which fall ofr and leave alternate, distichous, spine-like processes.

Common on exposed shores below low-water mark. Throughout the Jear. Europe.

A coarse and hom.ly speciey as usually found ; often washed ashore in lareme masses. Sot likely to be confonuded with any other of our species. In spring it presents a feathery appearance, owing to the tufts of hairs with which the froml is loeset. It is one of the species usecl as a fertilizer on the northern eoast of New England.

D. vintors, Lam. (Dichloria viridis, Grev-Desmarestia viridis, Phyc. Brit., Pl. 312.)

Fronds light olive, one to three feet long, cylindrical or but slightly compressed; branches all opposite, distichous, several times pinnate, ultimate branches capillary.

Common on stones at and below low-water mark. Europe.

A smaller and much more delieate species than the last, for which it ran never be mistaken, rather resembling in some of its conditions a Dictyosiphon. The name is derived from the fact that on decaying or on being placed in fresh water it turns quickly to verdigris-green. IIarvey mentions that air-eavities are to be seen in erosssections of the filaments. The air-cavities are, however, merely the sections of the larger cells which are surroumleal by denses masses of smaller cells, whereas in $I$. aculeata a cross-section sluws the axial filament surromuled by a mass of ecells of nearly equal diameter.

\section{FaMily DICTTOSIPHONEA.}

Fronds branching, filiform, axis composed of elongated cuboidal cells, the cortex of smaller roundish cells; unilocular sporangia spherieal, scattered or aggregated, formed from the subeortical cells; plurilocular sporangia unknown. 


\section{DICTYOSIPHON, Grev.}

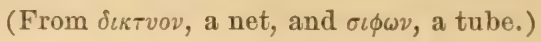

Fronds olive-brown, filiform, branching, solid above, becoming hollow below, cortex composed of small, irregularly polygonal cells, interior of larger, colorless, longitudinally elongated cells; branches corticated throughout; growth from an apical cell (scheitel-zelle); unilocu. lar sporangia spherical, scattered, immersed in the cortex; paraphyses and plurilocular sporangia unknown.

The genus was founded on D. foniculacens, a species placed by C. A. Agardh and Lrngbre in Scytosiphon. Under D. foeniculaceus were included a number of forms which have since been separated by Areschoug and placed in two different genera, Phlcospora and Dictyosiphon. In the former the unilocular sporangia are formed directly from the cortical cells and cover the surface in dense patches, at maturity projecting above the surface of the frond. In the latter genus the sporangia are scattered and immersed. In Dictyosiphon, moreover, the growth is from an apical cell, but in Phloospora it is trichothallic, and in the former genus the superficial cells are polygonal and irregularly placed, while in the latter they are quadrate and arranged in regular series. The genus is divided by Areschoug into two subgenera, Dictyosiphon proper and Coilon ema, the latter of which is referred by Gobi to Cladosiphon, since the cortical layer consists of very short filaments rather than a continuous cellular membrane. Our two species belong to Dictyosiphon proper, but species of Coilonema and Phlcospora are to be expected in the region of Eastport. By Harrey the genus was placed in the Dictyotaca, from which order it was necessarily removed when the true nature of the sporangia was discovered.

D. Feeniculaceus, Grev. (Scytosiphon foniculaceus, Ag.-D. foeniculaceus, Phyc. Brit., Pl. 326; Areschoug, Phyc. Mar., Pl. 7.)

Fronds yellowish brown, six inches to two feet long, much branched; branches alternate or occasionally opposite; superficial cells angularly quadrate.

Common on stones and algæ at low-water mark. Spring and summer. Europe.

A variable species as found on our coast, but one which cannot well be subdivided at present. Early in the season the fronds are light colored and delicate in substance, but later they become more rigid. Perhaps some of the forms which we have here included may properly be placed under var. flaccidus of Areschoug. Such, at least, appears to be the case with some of the specimens collected in May at Wood's Holl.

D. HIPpUroIdEs, (Lyngb.) Aresch.? (Scytosiphon hippuroides, Lyngb., Hydr., Pl. 14 b.-D. foeniculaceus a, Aresch., Phyc. Mar., Pl. $6 a$ and $b .-$ Chordaria flagelliformis var. $\beta$ and $\gamma$, Agardh, Sp. Alg., Vol. I, pp. 66 and 67.)

Fronds dark brown, four inches to two feet long; main branches rather densely beset with flagellate, scattered, subequal secondary branches; superficial cells in the lower part arranged in horizontal series, above irregular. 
Exs.-1lg. Am. Bor., Farlow, Anderson of Eaton, No. 95.

On stones at low tide.

Eastport, Maine; Cape Ann, Mass.

We have referred to the present species a rather larece form found abumlantly in September, 1-iT, at Lastport, near logr Island, where it grows with Chordaria Altgelliformis, which it some.w hat resembles in habit. It is much coarser than I). fienioufucus, and of a darker color, and the liranches are long and thagellate, and furnished with comparatively few secomblary loranches. The Cape Ann specimens ares smaller and apploach nearer 1 . foniculaceus. The Eastport form ean hardly be regarded as an extreme state of 1 ). funiculaceous, but whether it is really the I). hippuroides of Areseluonge admits of some doulht, as Aresehong deseribes his speries as being only six or seren inches long. Aecording to Areschoug, the conjugation of zoospores has been ob)served in this species.

\section{FAMILY ECTOCARPEA.}

Fromds tilamentous, monosiphonous or sometimes partly polysiphonous, cortex rudimentary or wanting; sporangia either in the continuity of the filaments or external, sessile or stalked; unilocular sporangia globose or enboidal ; plurilocular sporangia muriform (formed of numerous small rectangular cells densely aggregated in ovoidal or lanceolate masses); growth trichothallic.

Fronds polysiphonous abore, monosiphonous helow, densely beset abore with very short horizontal branches....$\ldots \ldots$........ Myriotrichia. Fronds generally monosiphonous throughout, branches free, opposite or

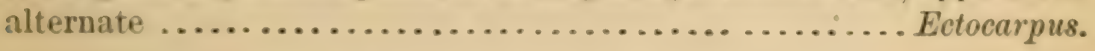

\section{MYRIOTRICHIA, Harv.}

(From $\mu v \rho\llcorner o s$, a thousand, and $\theta \rho \iota \xi$, a hair.)

Fionds olive-brown, filamentons, at first consisting of a single row of cells, which by transrerse and longitudinal division afterwards form a solid axis; branches short, closely approximated, radiating in all directions, formed by outgrowths from the superficial cells of the axis; unilocular sporangia spherical, borne on the axis between the branches; plurilocular sporangia unknown; main axis and branches euding in hyaline hairs.

A genus comprising three species which are harily distinct. They form small tufts or fringes on different I'hosporere, especially on Srytosiphom, and are recounized hy the numerous short hranches which in some cases almost cover the main axis ame cause it to resemble a sligonema. The derelopment of the fromb is given in de.tail by Nacreli in Die nevern Algensysteme.

M. Claverolims, Harv., Ihye Brit., Pl. 101. (M. Harryana, Naeg. partim.)

Fronds half an inch to an inch in length, chub-shaped in outline, axis chothed thronghout with branches, upper branches longer than lower and bearing secondary branches. 
Var. FILIformis. (M. filiformis, Harr., Phyc. Brit., Pl. 156.-M. Harveyana, Nreg. partim.)

Fronds filiform in outline, axis furnished only at interrals with branches.

On various algæ, especially Scytosiphon tomentarius.

Gloucester, Mass., Mrs. Bray.

Var. filiform is, Penobscot Bay, Maine, Hooper ; Newport, R. I.; Europe.

A species forming small tufts on different Phccosporea, probably abundant on our coast, but as ret only recorded in a fer localities. Nægeli has shown, l. c., that the two species of Harrey are merely forms of a single species, the variety filiformis being less fully developed than $M$. clarceformis, which was first described.

\section{ECTOCARPUS, Lyngb.}

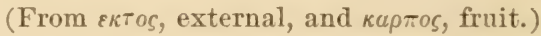

Fronds filamentous, monosiphonous or occasionally partly polysiphonous by radial division of some of the cells; plurilocular sporangia orate, cylindrical or siliculose, consisting of numerous small cells arranged in regular longitudinal and transverse series; unilocular sporangia cylindrical or oral, either stalked or formed by the direct transformation of the cells of the branches.

The genus is here accepted in an extended sense, and includes a number of genera of modern writers which we have preferred to consider subgenera. Perhaps Pylaiella should be kept distinct, as in this subgenus both the unilocular and multilocular sporangia are formed by the direct transformation of some of the cells in the continuity of the filaments rather than in special branches. But in Capsicarpella we have the multilocular sporangia formed in the continuity of the branches as in Pylaiella, while the unilocular sporangia are partly emergent and seem to be intermediate between those of Pylaiella and Ectocarpus proper. Streblonema, if separated from Ectocarpus by its creeping habit, resembles it perfectly in its fruit, and, as the different species of Streblonema vary considerably as to their procumbent habit, it seems, on the whole, better not to retain the genus. The described species of Ectocarpus proper are very numerous, but unfortunately they are not well characterized. The greater part of the species may be grouped around $E$. conferroides and $E$. fasciculatus as types, but exactly how far differences in ramification and dimensions of the sporangia are to be considered specific rather than mere rariations is a matter about which botanists do not agree. One thing is certain, that specific analysis has been carried too far in this group, and it is especially true with regard to the species of Kützing. In describing a species of Ectocarpus it is important to have both the unilocular and plurilocular conditions. In most of the species, howerer, only one form is known. The unilocular sporangia are often difficult to determine, because the Ectocarpi, especially those growing on dirty wharves, are infested by parasites, Chytridium, \&c., which produce globular swellings of the cells, which might then, especially in dried specimens, be mistaken for unilocular sporangia.

Besides the two forms of sporangia, Thuret and Bornet hare recorded the existence of bodies to which they have given the name of antheridia. It has been suggester that the antheridia were cells distorted by parasites. We have never seen antheridia in American specimens, and are not in a position to express any opinion. The fact that a conjugation of the zoospores has been observed by Goebel in $E$. pusillus 
wonld however, ineline one to consider that the antheridia in this gemus were not proper male lublies.

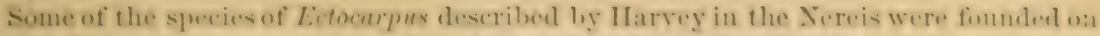
sterile specimens, lut, at the present day, algologists agree in thinking that the pros-

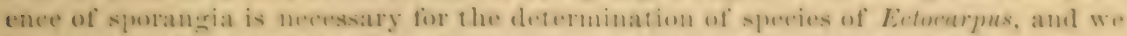

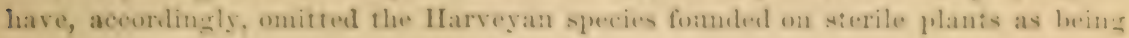
inadoguate.

Sergexes Strebloxema, Dorl. \& Sol. (Entonema, Reinsch).

l'ambry branches procumbent, (reveping in or over the substance of

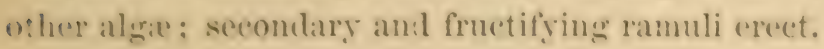

\section{E. Chordarie, n. Sp.}

Filaments much branched, irrexularly nodose, about .0.2n in diam. e:or, sank in the tissus of tha ho it-plant; hairs and fertile bianches erect, the limer projerting above the surfiee; unilocalar sporangia on short stalks, solitary or clustered, oval, about $.07^{\text {mm }}$ broad by $.14^{\text {mm }}$ long: plurilocular sporangia unknown.

Parasitic in the fronds of Chordaria divaricata, Leathesia tuberiformis, and other Pharosporea.

\section{Wool's Holl, Glowcester, Mass.; Newport, R. I.}

A common but insignificant spreies which grows in the cortical portion of different Phomsporen. especially Chorduria diruricata, and usually in company with Iiulbocoleon. It forms lark-colored spots on the surface of the plant in which it is growing, and, on a lasty microscopic examination, would pass unnoticed, so great is the resemblance of the spmrangia to these of Chorduria. Our plant resembles S. sphericum, Thuret, but diffirs frum the. Meliterranean forms of that speecies in having oval, not spherical, sporangia, which are often chstered. The filaments, too, are composed of very irregular-shaped erlls, and are never moniliform as in well-developed specimens of $\mathrm{S}$. spluaricum. It may, huwever, be the case that what wo have considered specifie marks are only local variations. It may also be asked whother the present species is not the form of $s$. freciculutum, Thuret, which luars unilocular sporangia. At present only the plurilocular form of sporangium is known in that species as it oecurs in Europe.

E. reptaxs, Crouan, Florule du Finistère, p. 161; Kjellman, Bidrag till Kïnn. Skand. Ect. Tilop., p. 52, Pl. 2, Fig. 8.

Filaments forming circular spots on the host-plant, primary hranches very densely branching, so that they almost form a membrane, furnisherl with numerous ereet branches, which are .5-7wa high and gradually taper to a hyaline hair; cells at base about .01 sporangia arising from the primary filaments, sessile or on short stalls, orate-acute, .012-20-m broad hy .035-i6-m long.

On Phyllitis and Dictyosiphon. Summer.

Newport, R. I.; Europe.

A larger species than the preceding amil growing more supurficially, so that the filasuents may be said to ereep over the surface rather than in the sulmatince of the hostflant. Owing to the dense branching of the prostrate filaments and the abundance 
of the erect branches, this species forms a comnecting link between Ectocarpus and Myrionema.

\section{SUBgExUS EUECTOCARPUS.}

Filanents monosiphonus, erect, occasionally corticated by the growth of descending filaments which are giren off from some of the cells; both unilocular and plurilocular sporangia formed by the transformation of special branches.

E. Tomextosts, (Huds.) Lyugb., Phyc. Brit., Pl. 182. (Spongonema tomentosum, Kütz., Spec. Alg., p. 461; Tab. Phyc., Vol. V, Pl. 83 a.)

Filaments erect, two to four inches long, densely interworen into rope-like, spongy masses, irregularly much branched; primary branches scarcely distiuct; cells .008-12 $2^{\mathrm{min}}$ broad by .012-70 $0^{\mathrm{mm}}$ long; plurilocular sporangia linear-o long, straight or incurved, .010-15 $5^{\mathrm{min}}$ broad by $.025-75^{\mathrm{mm}}$ long, sessile or on short pedicels, which are giren off at right angles to the branches; unilocular sporangia "suborate on short pedicels" (Areschoug).

On Fucus and other plants.

Boston Bay, Harvey; Magnolia, Mass.; Europe.

This species, which is easily recognizable by its spongr, rope-like habit, and by the microscopic characters above enumerated, seems to be rather scarce ou our coast. It is not rare, however, on the shores of Europe. The species is to be songht in summer, and it grows attached to the larger alg:e. Only the plurilocular sporangia are known on our coast.

E. Granulosus, (Eng. Bot.) Ag.; Phyc. Brit., Pl. 200.

Filaments tufted, rather rigid, two to four inches long, main branches opposite or whorled, corticating filaments often numerous; cells $.07-10^{\mathrm{mm}}$ in diameter; secondary branches short, opposite, given off at very wide angles, often revolute at the tip ; ultimate branches secund, short, acute; plurilocular sporangia broadly orate, obliquely truncate on the inner side, .0t-6 $6^{\mathrm{mm}}$ broad by $.06-8^{\mathrm{mm}}$ long, sessile on the ultimate and penultimate branches; unilocular sporangia?

Var. Tenuis. (Ectocarpus Durkeei, Harr., Ner. Am. Bor., Vol. I, p. 142, Pl. $12 f$.)

Filaments more slender than in the trpe; cells $.05-S^{\mathrm{mm}}$ broad; branches usually alternate; plurilocular sporangia orate or ellipsoidal, but slightly truncate at the base.

Boston, Harvey; Newport, R. I.

Var. tenuis, Portsmouth, N. H. ; Nantucket, Mass., Harrey; Wood's Holl, Mass.

A species not rare in Europe and apparently common on the coast of California, but not often found with us. The species occurs in summer, and forms small tufts on 
other alyse. It is distinguinhed from our other speecies lyy the short, broal, and sessile sporangia. In the type the hranehing is oppusite and compact, and the eortieating filaments are sometimes so numerous, especially in the Yewport specimens, as to leam one to admit the validity of Kiitzing's gemus Cirtirularin. But in other cases the corticating filaments are few in number.

E. Coxpentomes, (Roth) Le Jolis. (Ectocarpus siliculosus, Phyc. Brit., Pl. 162 ; Ner. Am. Bor., Vol. I, p. 139.)

Filaments erect, two to twenty inches long, loosely entangled at the base, baconing free and feathery abore; banches alternate or secund, gralually tapering; calls of larmer brancines .01-, - $^{-10}$ in diameter; plurilocular sporangia ovate-acute or acuminate, sessile or stalked, sometimes rostrate average size of sporangia . $02.5-40^{-m}$ broad by $.15-40^{-m}$ long;

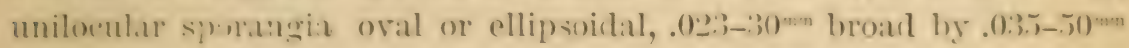
long.

a, var, stluctuost's, Kjellman. (Estocurpus ririlis, IIary, Ner. Am. Bor., Vol I, p. 140, Pl. $12 b$ and $c$.)

Plurilocilar sporangia subulate or linear-subulate, sessile or suh). sessile, frequently rostrate.

\$, var. ImEndus, Kjellman. (E.tocarpus hiemalis, Cronan.)

Plurilo enlar sporamia elongated, conical or subasuminate, .03-1.; long by .02-3 $3^{\mathrm{mm}}$ broad, generally rostrate.

Very eommon on algie and wood work along the whole coast.

Var. $\alpha$, most common south of Cape Cod.

Var. $\beta$, Wood's Holl, Mass. ?

The laremet. most variable, and most common snmmer species of our eoast, amel foumd in nearly all parts of the world. It has been subdividerl hy kitziner into a larige number of speries, whirh are seareely to be recornized from his deseriptions and plates. Formerly some of the different forms of $\mathrm{L}$. littoralis were referred to the present spereies, but the true E. littoralis is now recognized as belonging to the

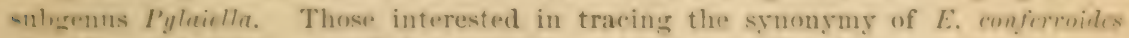

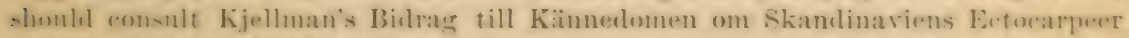
wh.h Tilopherisler, stowklusm, 1-i2. As seen on our own coast, what we have calleal the typrical $l$. conferroides forms tufts of indefinite extent on wharves, amd esperialls on the larger aleate varying in length from a fiow inehes to a foot and a half lone. It firepuently fringes the fromels of Chorde filum with its soft, silky tufts. In the type the pluriloenlar spurangia, which are much more common than the unilocular, are ovate-aeminate, and ouly oceasionaliy rostrate. In the variety xilienlesus the pluri locular sporangia are long and comparatively very narrow. The variety hiemelis is foum in the winter and spring, and has plurilocular sporangia, which are almust always rostrate and somewhat eylindrieal in form, so that they may be said to resembe those of the sulyenns Pylaiella. The color of the present species when growing is a light lomwn approaehing yellowish, which in drying often turns to a grllowi-hgreen, especially in the variety siliculosus, of which herbarium specimens might toe mistaken for Cludephore. The winter forms are decper brown than those found in snmuer. E. amphihius, mentimed in the supplement to the Xere.is as occurring near New York in brackish water, is a form of the present species. 


\section{E. Fasciculatus, Harv.}

Filaments one to eight inches long, erect, tufted, entangled below but free and featbery above; cells of main branches $.05^{\mathrm{mm}}$ in diameter, about as long as broad; secondary branches alternate, short, given off at an obtuse angle; ultimate branches very numerous, secund, ending in a hair; plurilocular sporangia ovate-acuminate or subulate, sessile or on short stalks, borne principally on the upper side of the penultimate branches, very variable in size, but averaging from .018-25 $5^{\mathrm{mm}}$ broad by $.070-150^{\mathrm{mm}} \mathrm{long}$; unilocular sporangia sessile, oval, .04-6 $6^{\mathrm{mm}}$ by .03-45 ${ }^{\mathrm{mm}}$.

Very comnon on the larger algæ along the whole coast; Europe.

When found in its typical form the present species is easily recognized, but it raries considerably, so that the extreme forms are not easily determined. It is very common on fronds of Lxminaria and other large Phceosporex, on which it forms a dense fringe one or two inches high. The larger forms are much looser and feathery and the tips of the branches are fasciculate when seen with the naked eye. When long and slender it becomes the var. draparnaldioides of Cronan. The most puzzling forms are those in which the filaments are short and thick and the rather stout plurilocular sporangia are arranged without order on the branches. In this species the unilocular and plurilocular sporangia are more frequently found growing together on the same indiridual than in any of the other species found on our coast.

\section{E. Lutosus, Harv., Ner. Am. Bor., Vol. I, p. 140, Pl. 12 a.}

Filaments tufted, two to four inches long, densely interworen in spongy masses; lower branches opposite, .03-4 $4^{\mathrm{mm}}$ broad; upper branches irregular, ending in long hairs; plurilocular sporangia .04-5 ${ }^{\mathrm{mm}}$ broad by .15-20 $0^{\mathrm{mm}}$ long, cylindrical in outliue, ending in very long hairs, which occasionally fork; unilocular sporangia?

\section{Greenport, L. I., Harvey; Wood's Holl, Mass.}

The above description is taken from a species common on Fucus at Wood's Holl, in May, 1376, which corresponds very well to the E. lutosus of the Nereis Am. Bor., a species which Harvey states is not clearly defined. It differs from the description given by Harrey in the fact that the sporangia are not very long, and it is not impossible that our plant may not be the same as that described by Harvey. The present species, as we understand it, is short and tufted and the filaments are densely inter. woven into rope-like masses as in $E$. tomentosus,. The species seem to connect Pylaiellu ivith Euectocarpus, resembling on the one hand E. siliculosus var. hiemalis, and on the other E. firmus. From the former it differs in the branching and the shape of the plurilocular sporangia, which are strictly cylindrical, never being in the least acuminate. From the latter it differs in being more slencler and in having the sporangia always at the base of very long hairs, which sometimes branch, and not in the contiunity of the branches themselves. The ramification is very like that of E. firmus. In drying the species becomes decidedly yellow.

E. Mrtciella, IIarv., Ner. Am. Bor., Vol. I, p. 142, Pl. 12 g.

"T'ufts feathery; filanents very slender, decompoundly much branched; the branches and their lesser divisions alternate; the ultimate ramuli approximated; angles wide, and branches and ramuli patent; ramuli 
attenuate; articulations of the branches twice or thrice as long as broal, of the ramuli onee and a half as long; propagula elliptic-oblong or linear, quite sessile and rery obtuse, transwersely striate, several to gether." (Ilarrey, 1. c.)

Nantucket, Miss Mitchell.

Ouly known fro:u the description and plate in the Nereis.

Subgexes PYLAIELla, Bory.

Both forms of sporangia formed from the cells in the continuity of the branches, and not by a transformation of special branches.

In the present sul fenus one might, at first sight, be inclined to include Es siliculosus var. hirmulis and $\mathrm{E}$. lutesus, but in those species the sporangia are rather situated at the end of hranches, which are prolonged be gond the sporangia in the form of hairs. than in the continuity of the branches themselves.

E. Litronalis, Lyngb. (Ectocarpus firmus, Ag.-Pilayellu littoralis. Kjellman.)

Filaments tufted or irregularly expanded at the base, two to ten inches long; branches numerous, usually opposite, given off at widle angles, erect; cells .02-4 broad; plurilocular sporangia irregularly eylin lrical, very variable in size; unilosular sporangia formed of from two to thirty contigmous cells, $.02-3^{m}$ brom ; fertile branches moniliform.

Var. nonestes. (Eetocurpus Furlocii, Thuret, in Farlow's List of the Marine Algie of the United States, 1876.)

Filaments three or four inches long, densely branehing; branches rolust, opposite or irregular; cells .03-5 in brealth; fertile branches short and rigid, often transformed through nearly their whole length into unilocular sporangia, which are stont and eylindrical, only slightly

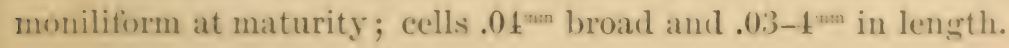

Very common along the whole coast.

Var. robustus in exposed places from Nahant north ward.

A very common speeies on our const, which, although offering numerons forms, cannot, as it seems to us, be well specifically divided. When growing on wharses, where it is very coumon, or on other wond work, it forms expansions of indefinite extent from which rise tufts sereral inches long. The hasal or prost rate portions loraneh very irregularly, and the cells are inferted with chytridia and other parasites. If speries of Litenctpus conlal the formed from sterile speeimens, the basal portions of $E$. lithoralis would ofler a rich fieht to the spee ies-maker. What is ealled rar. robustus has not yet been foumb sonth of Cape Cod, but is oommon on the northern coast on Fwi and other aline exposed to the artion of the wases. The original E. Forloveii was foumled on specimens collected loy Mr. Highee, at Salem, in November, 1-74, and pronommed by the late $\mathbf{M}$. Thuret, in a letter dated $A_{\text {pril }} 26,1-55$, to be distinct from $E$ : littoralix. In the Contrilutimes al Algologiam et Fungologiam, Pl. 20, Reinseh figures, under the name of Letucurpus untirostiensis, a form which, as far as can be 
julged from the figure, is the samo as $E$. Farlowii. Although in the present instance we have considered $E$. Farlowii to be a variety of $E$. littoralis, it must be almitted that it differs considerably from the form of $E$. littoralis common on the coast of France and Eugland. Our reason for not considering it distinct is that we have large sets of specimens in which we have been unable to say with certainty whether they should be referred to E. littoralis or E. Farlowii, and with so many connecting links it seems best to regard E. Farlowii as an extreme form found in northern localities. Should the variety be eventually considered clistinct the name of $E$. anticostiensis should be adopted, as no description of $E$. Farlowii has been published, and the species would be characterized by the robustness of the filaments and by the unilocular sporangia, which are broaler than long, and borne in short, stout, patent branches. It is of frequent occurrence that some of the unilocular sporangia are binate. The plurilocular sporangia are common in spring and early summer, and the unilocular in the autumn.

E. BR

"Finely-tufter, feathers, much branched; the branches free, opposite or quarternate; ramuli opposite, very patent; propagula forming oblong or elliptical swellings in the smaller branches, or at the point where two opposite ramuli issue." (Harv., Ner. Am. Bor., Tol. I, p. 138.)

South Boston, Lynn, Mass., Harvey.

We have nerer found this species, which is only known on our coast from Harrey's lescription. Le Jolis considers that the E. brachiatus of the Phyc. Brit., Pl. 4, is not the true Conferra brachiata, Engl. Bot., and he gives to the former the name of $E$. (iriffithsianus. Never having seen American specimens, we cannot tell whether the American form mentioned by Harvey belongs to the $E$. Griffithsianus or not.

Subgexus CAPSICARPELLA, Kjellman.

Filaments erect, monosiphonous or in part polssiphonous; unilocular sporangia partly immersed in the frond ; plurilocular sporaugia formed by direct transformation of the cells of the branches.

E. Sph zerophorus, Harr, Phyc. Brit., Pl. 126. (Capsicarpella spharophora, Kjellman, Bidrag, p. 20, Pl. 1, Fig. 2.)

Filaments one to three inches long, tufted, densely branching; main branches opposite or whorled, often polysiphonous; secondary branches opposite or alternate, monosiphonous; unilo ular sporangia spherical, about $.04^{\mathrm{mm}}$ in diameter, solitary, often binate, sometimes whorled, the cell from which the sporangia are formed dividing into at least three cells; plurilocular sporangia ?

On Ptilota elegans. May.

Nahant, Mr. Collins; Europe.

$\Lambda$ rare species which has only been collected by Mr. Collins. The main filaments are at intervals polysiphonous, and remind one of a Sphacelaria. In Mr. Collins's specimens the sporangia were numerous and in some cases whorled, as is occasionally seen in European specimens. The species is to be sought in spring and early summer, and may be commoner than is now supposed, having escaped the observation of collectors on account of its small size. 


\section{I.SUFFICIEYTLY DESCRIBED SPECIES.}

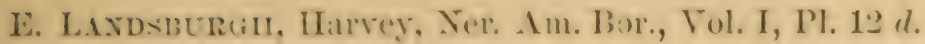

Ilalifix, $\mathrm{X} . \mathrm{S}$.

E. Hooperi, Harvey, l. e., Pl. $12 e$.

Greenport, I. I. (?)

E. Dietzi.e, Пarrey, 1. c., p. 114.

Greenport.

\section{FAMILY SPHACELARIEA.}

Fromls branching, polysiphonous, terminating in a larege apical cell, otten with a cortex formed of densely interwoven rhizoidal filaments; fructification same as in Ectocarpea.

Corticating cells wanting or confined to the base of the fromb.

Irain branches corticated thronghout.

Sphacelaria.

IBranches opposite, distichous................ Chetopteris.

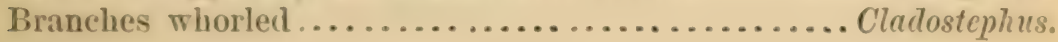

\section{SPHACELARIA, Lyngb.}

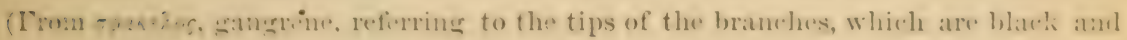
shriveled when dried.)

Fromls olive-brown, filamentous, branching; axis and branches terlainateal by a large apical cell, from which, by transrerse, longitulinal, and oblique dirisions, a solir firoud is formed whose external surface is composed of rectangular cells arranged in regular transverse bands; hairs slightly dereloped or wanting; rhizoidal filanents few, rarely interworen so as to form a filse cortex; unilocular and plurilocular sporangial spherical or ellipsoirlal, on short pedicels; non-sexual repro. production by peculiarly morlified branches called propagrula.

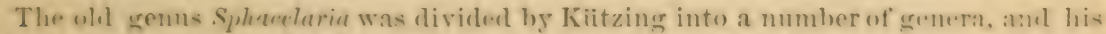
view shave been atopteel by many recent writers, especially in (iermany. In stypocrulom and Ilulopteris the branches arise from lateral dirisions of the appical cell itself, while in sph veduria proper, Chatopteris and Cludestephus, the branehes arise from cells luetow the apes. Whether this ditierenee in the apieal growth can be considered at

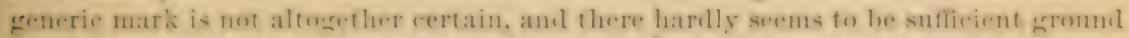
for separating Ifalopteris from sphemlaria, amb a number of wrisers, amone whom

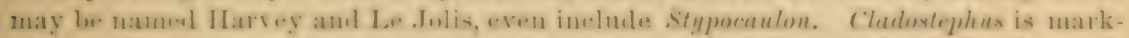

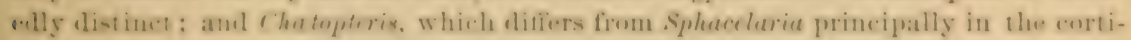

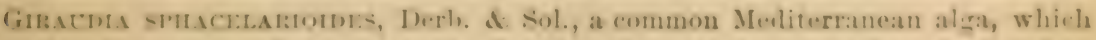
oceasionally oreurs as far morth as the somolinarian coast, may perliaps le foumb ou our shore. It resembles a small sphaeelaria, but its growth is tuichothallie, not from an apieal cell, and the small uniloenlar sporangia coser the frond in dense pateleses.

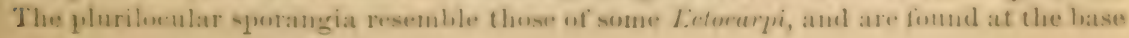
of the plant according to Areschoug. 
cation of the main branches, is kept distinct by most writers. We have but a rery imperfect representation of the Sphacelarioid group in this country. Stypocaulon and Halopteris are entirely wanting, and of Sphacelaria we have only S. cirrhosa and $S$. radicans on the northeastern coast, $S$. tribuloides in Florida, and what is supposed to be S. fusca in California. The species of Sphacelaria are variabie, and the determination sometimes uncertain. The apical cells of our Sphacelaria are frequently attacked by the unicellular parasite, Chytridium sphacelarum, Kny.

\section{S. Cirrhosa, (Roth) Ag.; Phyc. Brit., Pl. 178.}

Fronds olive-brown, densely tufted half an inch to two inches high; main filaments erect, several times pinnate with opposite or irregularly spreading branches; rhizoidal filaments few or wanting; unilocular sporangia .06-7 $\mathrm{mm}$ long, globose; plurilocular sporangia .05 ${ }^{\mathrm{mm}}$ broad by $.08^{\mathrm{mm}}$ long, broadly ellipsoidal, secund on lateral branches, with unicellular pedicels; propagula rather stout, three (2-4) rayed, usually borne on distinct plants.

\section{Common on Fucus, on which it forms dense globose tufts. Europe.}

A rariable species, sometimes with regularly opposite branches, at times with irregularly placed long branches. The propagula vary very much in size, and are generally found on plants which do not bear sporangia. With us they are much more common than the sporangia. An excellent account of the propagula is given by Janczerrski in the Annales des Sciences, Series 5, Vol. XVII. In the Nereis Am. Bor. the word propagulum is used by Harrey to signify the contents of the apical cells, and this use of the word should not be confounded with its present application. The word propagulum as used in the Nereis is rather equivalent to the term sphacela of other writers. Sporangia are more common in the winter months, but are found occasionally in summer.

S. RADICAxs, (Dillw.) Harr. (S. olivacea, rar., Ag.; Pringsheim, l. c., Pls.9 and 10._S. radicans, Phyc. Brit., Pl. 189.)

Fronds olive-brown, half an inch to an inch high, forming dense turfs; filaments erect or prostrate, branches fer, somemhat appressed, rhizoidal filaments often numerous; unilocular sporangia globose, $.04-5^{\mathrm{mm}}$ in diameter, numerous on the branches, on very short unicellular pedicels; plurilocular sporangia unknown; propagula sleuder, elongated.

On mud-covered rocks between tide-marks.

Newport, R. I.; Wood's Holl, Mass., and common from Nahant northwards; Europe.

The present species is smaller than the last, and forms small, indefinitely expanded turfs, especially on the under side of mud-covered rocks, often in company with Ceranium Hooperi. Numerous rhizoidal filaments are sometimes found at the base, so that different plants aro bound together, but the species is without a false cortex. The name originally proposed for the species by Dillwyn was S. radicans. Agardh adopts Dillwyn's later name, S. olivacea, making of the form with numerous rhizoidal filaments a variety, radicans. Apart from their different habit and place of growth, it is difficult to assign exact marks by which to distinguish in all cases $S$. cirrhosa and $S$. radicans. In the latter the secondary branches are few and appressed, irregularly placed, never opposite, while in the former they are numerous, given off at wide 
angles, and frequenty opposite. In S. rimhose the sperangia are generally seattered on the secombary branches, while in $S$ radicans they are often clustered on the main liranches. In both cases the peediects are nsually one-celled. In both species the propagula are so variable in outline that they cantuot he deseribed in few words, but thue of S. cirrhosa are more robust than those of S. radicans.

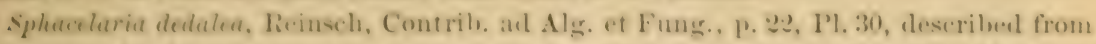
the coant of Labrator, dees not eorrespond to any form known to us from New England.

\section{CHETOPTERIS, Kiitz.}

(From $\chi a \iota t \eta$, a hair, and $\pi \tau \varepsilon \rho \iota$, a fern.)

Fronds olive-brown, filamentons, branching; branches opposite, dis. tichous, apieal growth as in sphuceluria ; rhizoidal filaments very numerous, densely interworen, so as to form a false eortex; plurilocular sporangia borne on the branches, shortly pedicillate, unilocular sporangia "globose on the tipss of short special filaments" (Areschoug).

A genus founded on the old sphacelaria plumosa of Lynghye. It differs from Sphacelariu in the false cortication of the main branches by the interlacing of rhizoidal filanents, and from Cludostephus by the opposite, not whorled branches. The genus clues not rest on a firm hasis, for it oceasionally happens in some of the species of sphaalaria that the rhizoidal filaments form a rulimentary cortex. Chetopteris squamulusa, Kiitz., is made by Geyler the type of a new genus, Phloiocaulon.

C. PLumosa, (Lyngb.) Kiitz. (Sphacelaria plumosa, Lỹngb., Pliye. Brit., Pl. 87.-Chatopteris plumosa, Kiitz., Phyc. Gen., 1. 29:3; Tab. Phỹc., Vol. 6, Pl. 6, Fig. 1; Areschoug, Obser. Pliyc., Part III, Pl. 2, Figs. 4 and 5.)

Fronds two to six inches long, tufted, rigid, attached by a small disk, main branches sparingly branched, secondary branches plumose; plurilocular sporangia numerous, secund on the upper side of short special branches, shortly stipitate, elliptical in outline; unilocular sporangia globose, terminal on short branches. (Areschoug, l. c.)

I'rince Edward's Island, Mrs. Duris, and northward; Torthern Enrope.

A beautiful species, common in Northern Europe and Greenland, but not yet found farther sunth than I'rinee Eilwaril's Island on the Ameriean coast. It may, however, be expected at Eastport and our northern border.

\section{CLADOSTEPHUS, $\Lambda \mathrm{g}$.}

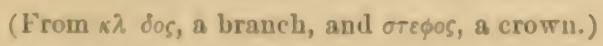

Fronds olive-brown, branching, secondary branches (leaves) whorlecl, apical growth as in sphacclaria; main stems densely corticated by growth of rhizoidal filaments, secondary branches (leaves) naked, hairs borne in tufts just below the apex of branches; unilocular and plurilocular sporangia on special branches (leaves), stipitate. 
A genus comprising eight described species, several of which are undoubtedly merely forms of the common and widely diffused $C$. verticillatus, whose structure is minutely described by Pringsheim, l. c. The term leaves is applied by Pringsheim to the secondary branches. He considers the branching of the axis to be monopodial. The sporangia are produced in the winter months, the two kinds on separate plants or sometimes together.

C. verticillatus, Ag.; Phyc. Brit., Pl. 33 ; Pringsheim, 1. c., Pls. 1-7.

Fronds four to ten inches high, slender, sublichotomous, secondary branches distinctly whorled, falcate, acute at apex, attenuate at base, furnished externally with a few spine-like branchlets; hairs numerous; muilocular sporangia globose, plurilocular sporangia irregularly ellipsoidal, borne on short pedicels on small special branches, which grow from the axis between the insertions of the secondary branches.

Tar. spongiosus. (Cladostephus spongiosus, Ag.; Phyc. Brit., Pl. 38.)

Fronds more compact, whorls approximate, indistinct, secondary branches usually destitute of hairs and spine-like branchlets.

On stones in pools and below low-water mark.

Nemport, R. I. ; Orient, L. I. ; Martha's Vineyard; Cape Aun, Mass.; Europe.

A plant at once recognized by its resemblance to a small Ceratophyllum. Rather common in several places south of Cape Cod, but seldom seen on the northern coast. It prefers somewhat exposed shores, and occurs at considerable depths. Although the close resemblance between $C$. verticillatus and $C$. spongiosus has long been noticed, the two species have generally been considered distinct. Geyler says that C. spongiosus is characterized by the absence of hairs and the external spines on the branches. Although this is in general true, one not unfrequently finds hairs and small spines on some of the branches, and C. spongiosus is evidently merely a variety of C. verticillatus. Nor is it the case, as some have supposed, that the verticillate form is confined to deeper water, while the spongiose form is found in tide-pools and near low-water mark.

\section{FAMILY MYRIONEME无.}

Fronds minute, forming spots or thin expansions on other algæ, consisting of prostrate filaments united into a horizontal membrane, from which rise short vertical filaments, between which are borne the sporangia; unilocular and pluriocular sporangia as in Ectocarpece.

\section{MYRIONEMA, Grev.}

(From $\mu v \rho \iota s$, numberless, and $\nu \eta \mu a$, a thread.)

Fronds olive-brown, forming thin expansions on other algæ, composed of a horizontal layer of cells lying on the substratum, from which arise very numerous vertical filaments, closely packed together; unilocular and plurilocular sporangia between the rertical filaments, either sessile on the horizontal layer or on short pedicels; hairs arising from horizontal layer; growth peripheral. 


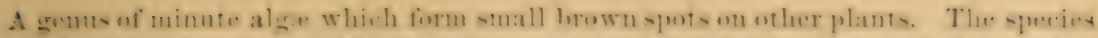

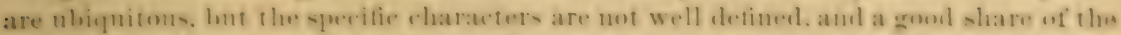
describerl sereies are merely different firms of the very common $M$. rulgare. The two

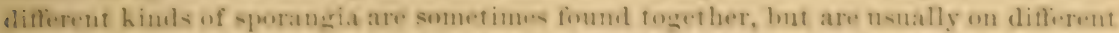

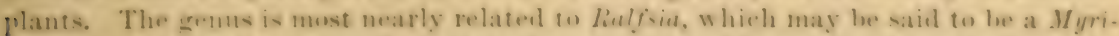
omema in whe he the herizental layer has become mueh thiekened, and the sertieal fila-

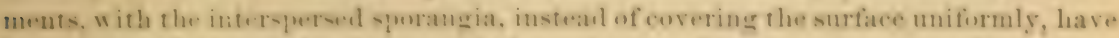

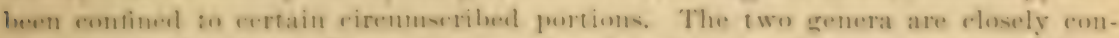

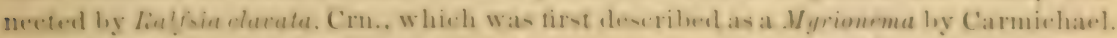

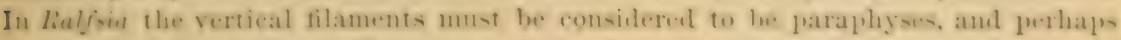
those of Myrionema should also be so considered.

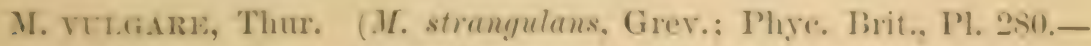

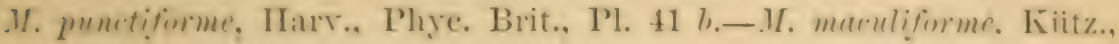
Tab. Phye., Vol. VII, Pl. 93, Fig. 2.)

Fromels .01-smm in thickness, vertical filaments (parapliyses) slightly

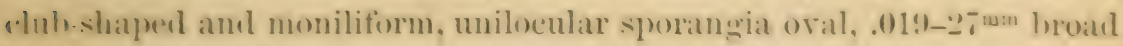
by . (1):-4 mm long. sessile or horne on short perlicels.

Everywhere common on rarious algæ.

In Le Jolis's Liste des Alines Marines de Cherbourer. Thuret is fuuted as aut lonrity for uniting several of the species of Myrionema of Harvey and Fitzing. The allenger sprecifie dist inetims are plainly not hing but moditications of the same species, dependent on the place of growth. When foumd on small eglindrical fromls, as in some Enteromorpha, the Myrionema surroumls the frond and constitutes the M. strangulans uf (ireville, and when growing on flat surfaces the form kuown as $\mathscr{Y}$. punctiforme is fond. In this comtry the unilocular sporangia are very common, hut we have never seen the plurilocular sporangia, while in the next species the plurilocular sporangia are more numerons, although both kinds are found.

M. I.echaycmerit, (Chaux.) Harv., Phyce. Brit., Pl. 41 a. Pl. 6, Fig. J. Fronds .06-10mm in thickness, rertical filaments (paraphyses) cylindrical, unilocular sporangiu oval. plurilocular sporangia .00S-10 wm broad ly .023-30mm long. orate. oblong, sessile or on very short pedicels.

\section{On Rhodymenia palmatr.}

\section{Gay Head, Mass.; Europe.}

This speeres forms rather larger spots than the last on the common dulse. That it is really distinet from $M$. rulgare admits of domlot. There apprars to be a difterence in the paraphyses of the two, hut such diffi-rences cannot le cousiclered of mueh value. We have foumd loth unilowular and plurilocular sporangia in the present species. but unfortunately have not preserved measurements of the lafter. The plurilocular sporangia are sometimes rery numerous and stand side loy side without inferrening laraphyses.

\section{Fantr LEATHESIE.}

Frombs lubricous or gelatinoms, indefinitely expanded or irregulanly globose, cousisting of a basal portion, composerl of irregularly loranching filaments formed of large, colorless ceells, and a cortical portion of closely packed, short, colorent filaments: parapluyses offen present; 
Fructification borne at the base of cortical filaments ; plurilocular sporangia cylindrical, composed of few cells in a row; unilocular sporangia globose.

Fronds forming small tufts on other algæ.

Cortex with a series of exserted colored filaments.......Elachistea.

Cortex destitute of exserted filaments .................. Myriactis. Fronds irregularly globose, hollow at maturity............ Leathesia.

\section{ELACHISTEA, Duby.}

(From $\varepsilon \lambda \iota \chi \iota \sigma \tau a$, very smali.)

Fronds olive-brown, tufted or pulrinate, basal portion solid, some. what parenchymatous, composed of densely packed branching filaments, which become free at the surface and branch corymbosely so as to form a layer of short filaments (paraphyses), at the base of which are borne the sporangia of both kinds and a series of long exserted filaments; hairs formed at the base of the paraphyses, exserted ; unilocular sporangia rhombic-oroid, plurilocular sporangia cylindrical, com posed of a few cells in a linear series.

A genus consisting of a fer species, all of which form small tufts on other algir, especially on Fucacea. They may be recognized by the double series of filaments borne on the surface of the solid and but slightly dereloped basal portion. The longer filaments and hairs float freely in the water, but the shorter paraphyses are packed rather closely together, forming as it were a definite cortical layer over the basal portion. The unilocular sporangia are common. The more or less solid basal portion of the fronds in some of the species gives off flaments which penetrate into the substance of the algre on which they are growing, and by the growth and persistence of these filaments it may be that the species are propagated from fear to year, as happens in the case of certain fungi. In other species no penetrating basal filaments have as jet been found.

The limits of the species are pretts well defined except in the case of $E$. fucicola, $E$. lubrica, and $E$. flaccidla, where it must be confessed the species show a tendency to run into one another. In the present case we have included in Elachistea only the species in which, besides the paraphrses which cover the surface, there are long projecting colored filaments as in E. scutulata, on which Dubs founded his genus Elachistea in the Botanicon Gallicon. Here undoubtedly belong E. fucicola and its allies, but the same can hardly be said of $E$. pulvinata, which was made by Kützing the type of his genus Myriactis. In this species the surface of the frond is covered by the paraphyses, but there is not in addition a series of elongated filaments as in E. fucicola, for the exserted hairs in E. pulvinata are of a quite different nature. We have referred $E$. pulvinata to the genus Myriactis, not, however, limiting the genus as Kützing has done, for some of the forms placed by him in Phycophila should be referred to Myriactis, although the greater part of them are correctly placed by algologists in Elachistea. It may be that there exist forms intermediate between the true Elachistece and Myriactis, but, from the study of dried specimens, we have not been able to come to such a conclusion. It shonld be remarked that M. pulrinata is placed in Elachistea by the most prominent algologists, as Thuret and Bornet, Agarlh, Harrey, Le Jolis, and others. The unilocular sporangia are most common. in summer, and the plurilocular sporangia are more frequent early in the season. 
E. rtercot.1, Fries; Phye. Brit., Pl. 2240; Ner. Am. Bor., Vol. I. P'l. 11 b. I'hycophila fiucorum and I', Agardhii, Kiitz., Tab. Phye, Vol. VIII, Pl. 95, Fig. 2, and Pl. 96, Fig. 1.) Pl. 7, Fig. 3.

Fromls tufted, half an inch to an inch in thickness, hasal portion clistiact, snbglobose, exserted filaments aboit $.05^{\text {ma }}$ broad, attenuated at base, obtuse at apex, cells of lower portion broader than long, becoming longer in the upper portion ; paraphyses reenrved, clavate, submoniliform; unilocular sporangia .07-5 broad by .15-20-3 long, priform or obovate-rhombic.

Common on Fuci along the whole coast.

On submerged wood work, Eastport, Pealis Island, Maine.

A rommon parasite, formine small tufts on Fuci. There seems to be but one sleecies on the coast of New England, although E. lubrime, Rupr., may be expected on Hulosecrion. According to Aresehong. E. Lubricadifters from E. fucicola in the shorter eells and the decidedly elongated hase of the free filaments, but in these respects Enrofean specimens of E. fucieola vary greatly. Possibly the form occurring on woend at

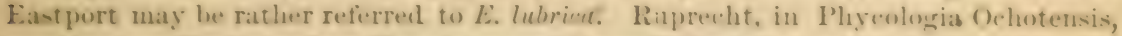
mentions an Eluchisten from Canala parasitic on Hulosuccion, which he considers distinct from both $F$. lubrien and $E$. fucienle, to which he grives the provisional name of $E$. canadensis. It is distingnished from $E$. fucicola "l,y the thicker filaments, which never give off free branches at the lase, by the dense, indistinctly filamentous structures of the hasal layer, and by the greater number of short filaments and few long filauents." From Ruprecht's description it is hardly likely that the species will ever be recognized by American collectors. The views of Ruprecht with regaril to development in alese are curionsly shown in his remarks on Elachista. Myrionema, and Leuthexia. He thinks it very probable that the genera named were "originally organs of fructitication of Halidrys. Cystoseira, Sce, which in course of time have not develnpect, and have in this way formed what appear to be stereotyped speecies." Alrhongh the fact is not as Rupree-ht supposed, this pronounced temleney to Darwinism is remarkable when we think that Ruprecht wrote in 1850.

MYRLACTIS, Kuitz., emend.

(From $\mu v p\llcorner o s$, countless, and cктьs, a ray.)

Fronds as in Elachistea, but destitute of exserted colored filaments.

A comparison of the two acluirable plates of Eluchistou seutulatu and Vilahister (Myviertio) pulrinata in the Etules Pluyeolegiques of Thuret and Bornet will give a clear nution of the difference of the two genera.

M. PUlvisata, Kiitz. Var. Mrson. (Elachistea pulrinata, Harr., in Etules Phycologiques, p. 1s, Pl. i-Elachistea uttenuata, Harr., Phỵe. Brit., Pl. 28.)

Fromels forming minute tufts, basal portion slightly developed, griring off lateral filaments, which penetrate the substratum; paraphyses slightly curved, fusiform, attenuated at base, somewhat moniliform; cells .007.)-180mm loroad, two or three times as long : plurilocular sporangia rery numerous, clustered at the base of the paraphyses, cylindri- 
cal, $007 \mathrm{C}^{\mathrm{mm}}$ broad by about $.057^{\mathrm{mm}}$ long, composed of $8-10$ cells in a row ; znilocular sporangia.

Parasitic in the cryptostomata of Sargassum vulgare. Summer. Wood's Holl, Mass.

This species forms minute tufts on Sargassum, and is so small as easily to escape detaction. It is furthermore likely to be mistaken for the hairs normally found at certain seasons in the cryptostomata. The description given abore applies to the plant found at Wood's Holl, which is smaller than the tรpical M. pulvinata of Europe, which grows in the cryptostomata of rarious Cystoseirc. In the European specimens examined the paraphyses were decidedlş stouter, rarely being less than $.018^{\mathrm{mm}}$ in breadth, whereas with us they are seldom more than .010-12 mm broad. Our plant is throughbut smaller than the European, but, in proportion, the paraphyses are longer and slenderer. It remains to be seen whether we are correct in considering our form a mere variety, or whether it should be kept distinct. Perhaps it may be the Phycophila arabica of Kiitzing, Tab. Phyc., Vol. 8, Pl. 1, Fig. 2, which grows on Cystoseira myrica. The species is not uncommon in summer at Wood's Holl, and both forms of sporangia occur together, the unilocular being much less abundant than the plurilocular.

\section{LEATHESIA, S. F. Gray.}

\section{(Named in honor of Rev. G. R. Leathes, a British naturalist.)}

Fronds olive-brown, gelatino-carnose, forming irregularly globose masses, solid when young, but soon becoming hollow; internal portion composed of radiating, dichotomous filaments, formed of large, irregular, colorless cells, the terminal ones bearing a series of short, simple, colored filaments (paraphyses), which are densely packed together, constituting the cortical layer of the frond; sporangia and hairs borne at the base of the paraphyses; plurilocular sporangia cylindrical, composed of few cells in a single row; unilocular sporangia pyriform or ovoid.

A small genus, comprising not more than half a dozen species, of which $L$. difformis is common in the North Atlantic. Leathesia Berkeleyi, Harv., now placed in the genus Petrospongium, Nig., although found not rarely in Europe and apparently tolerably common on the coast of California, has not jet been detected in New England, but may be expected. It forms rather leathery expansions on rocks at low-water mark.

L. DIFFonנms, (Linn.) Aresch. (Tremella difformis, Linn., Syst.Rivularia tuberifor mis, Engl. Bot., Pl. 1956._Corynephora marina, Ag., Syst._Leathesia tuberiformis, Gras, in Phyc. Brit., Pl.324, and Ner. Am. Bor., Vol. I, Pl. $10 c$; Thuret, in Ann. des Sciences, Ser. 3, Vol. XIV, PI. 26, Figs. 5-12.) (Pl. V, Fig. 1.)

Fronds from half an inch to two inches in diameter, solitary or aggregated, at first globose and solid, becoming irregularly lobed and hollow; plurilocular sporangia produced early in the season, unilocular sporangia in summer. 
Common on algie and on sand-covered rocks at low water along the whole coast.

Not to be mistaken for any other aliga ou our coast. The gelatinons halls which this species forms are fonnd growing in large quantities at low-water mark, and are sometimes called potatoes ly the unromantic dwellers on the shore.

\section{FaMiLY CHORDARIEA.}

Fronds cylindrieal, branching, usually gelatinous, with an axis of longitudinal filaments formed of long slender cells, and a cortex composed of short, densely packed horizontal filaments formed of subspherical cells: sporangia borne among the cortical filaments or formed direetly from them.

Fronds tough and elastic, cortical filaments densely united to one an-

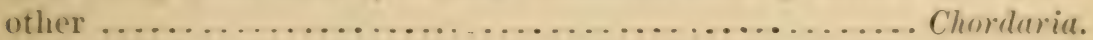
Fronds gelatinous, cortical filaments only adhering loosely to one another.

Upper eells of the cortical filaments producing the plurilocular

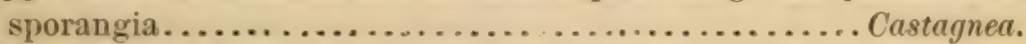
Upper cells of cortical filaments not producing sporangia.

Mesogloia.

\section{CHORDARIA, Ag.}

(From chorda, a chord.)

Fronds olire-brown, cartilaginous, filiform, branching; axial layer composed of longitudinally elongated cylindrical cells and smaller winding cells packed closely together in a solid mass; peripheral layer composed of short, simple, horizontal filaments, densely packed together; milucular sporangia oblong, borne at the base of the peripheral filaments (paraphyses), plurilocular sporangia unknown.

The distinction between the genera Chordaria and Mesogloia, in the absence of a know ledge of the derelopment of the fronds, must he gnite arbitrary. In the present instance we have considered that the genus chordaria should be limited to the forms having a tongh cartilaginous substance and solid axis, of which we have only one representative, C. Magelliformis. C. diraricata, both in its consisteney and the developunent of the froml, seens to belong to Mesoyloia, accepting that grenus in an extemled sense as we have done.

C. Flagelliformis, Ag.; Phye. Brit., Pl. 3. Pl. V, Fig. 2.

Fronds blackish, solitary or gregarions, attached by a disk, coriaceous, lubricous, one to two feet long, filiform, solid, main axis usually undivided, furnished with numerous long, subernal, flagelliform branches, which are given off at wille angles, simple or with few, irregular, secondary branches; peripheral filaments (paraphyses) few-celled, eylindrical or slightly club-shaped ; unilocular sporangia oroid or pyriform. 


\section{Var. DENSA.}

Fronds six to eight inches long, main axis densely elothed with rery numerous short branches.

Common on stones near low-water mark along the whole coast.

The var. densa at Gloucester, Mass., Mrs. Davis.

A common species, recognized by its tough, somewhat elastic substance, and reminding one of bunches of small leather shoe-strings. IVhen soaked in water it gives out a large amount of slime, and is not easily mounted. To the naked eye it resembles some of the forms of Dictyosiphon, but the microscopic structure is very different. The variety has been collected several times at Gloucester, but has not been received from other localities.

\section{MESOGLOIA, Ag.}

(From $\mu \varepsilon \sigma o s$, the middle, and $\gamma$ hocos, slimy.)

Fronds olive-brown, gelatinous, filiform, branching; axial layer composed of filaments rather loosely united into a solid mass, which soon becomes fistulose; peripheral layer of short horizontal filaments, packed in a gelatinous substance; unilocular sporangia oval, borne at the base of peripheral filaments; plurilocular sporangia unknown.

The old genus Mesogloia has been divided by modern algologists into a number of genera. In the present instance we have kept in Mesogloia the species in which the peripheral filaments are not transformed into plurilocular sporangia, and have placed in Castagnea the species in which they are so transformed. The distinction between Mesogloia and Castagnea is artificial, because the plurilocular sporangia of Mesogloia proper are unknown, and it is not impossible that they may be formed from the peripheral filaments themselves, as in Castagnea. The development of the fronds is not well known, and the genera founded upon the variations in the mature fronds in the present group are plainly artificial. As regards its development, $\boldsymbol{Y}$. divaricata resembles very closely $C$. virescens. From a disk-like expansion, composed of a single layer of cells, which form spots on the substance upon which it is growing, arise rertical filaments, which end in a hair such as is found in Ectocarpus and other Phcosporece. The vertical filaments produce, usually only on one side, fasciculated branches terminated by a hair, beneath which is a cluster of short moniliform filaments. Besides these there arise, at a later period, rhizoidal filaments. The mature fronds of the two species above named may be regarded as a collection of filaments with a trichothallic growth, which have become twisted together and partially united by means of the rhizoidal filaments, and whose fasciculated branches constitute what, in the mature plant, seems to be a distinct cortical layer. In Castagnea rirescens the separate filaments, with their lateral fasciculate branches, can easily be isolated by dissecting the smaller branches, and the same thing can also be accomplished with Chordaria diraricata, although not so easily. The species of Mesogloia and Castagnea should not be dried under too heavy pressure, and alcoholic specimens are much better for study than those mounted ou paper.

M. Divaricata, Kiitz. (Chordaria divaricata, Ag.; Phje. Brit., Pl. 17 ; Ner. Am. Bor., Vol. I, Pl. 11 a.)

Fronds tufted, lubricous, six inches to two feet long, branching very irregular, generally without a definite main axis; branches flexuous, ultimate branches very numerous, short, and divaricate, at first solid, 
afterwards beoming fistulose and tulular; peripheral filaments short. few-eelled, the last cell obovate and several times larger than the other eclls; unilocular sporangia oroid.

On algie and stones near low-water marl.

Verg common from Cape Cod sonthward: Yiles Beach, Gloneester. Mass.; Europe.

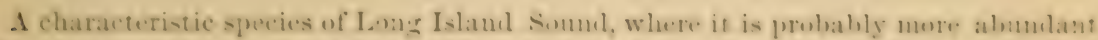
than in any other part of the world. It alomels in still, shallow bays. Jorth of Ciare Coul it is of sumall sias, and is only oceasionally met with. It asumes a number of different forms, none of which, however, ean he considered as distinet varieties. It firet aprears in May, and reaches perfection in Angust and september. At first the. frosuls are suall aud soliul, but they grow to be two fiet long, or eren longer, and the main branches become hollow and tinally collapsed. Except that they are nore luxuriant, our forms agree well with Norwegian specimens.

M. vermeularis, Ag.; Phyc. Brit., Pl. 31.

Fronds tufted, gelatinous, one to two feet long, branches long, irregularly pinnate, thick, rermiform, flexnous; peripheral filaments clavate, somewhat incurred, moniliform eells spheroidal ; unilocular sporangia oroid.

On stones and algæ between tide-marks.

\section{Halifax, N. S., Harrey; Europe.}

A rather common plant of Europe, and probahly oceurring within our limits, lont as Jor only reported at Halifax on the American coast. The species is rather thick and

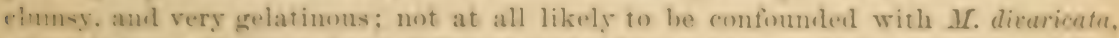
which is less gelatinons. has a diffirent mode of branching, and whose peripheral filaments are terminated by a cell mnch larger than the others. Dried sprecimens may lwe mistaken fur Cistagnen vireseens, a more slenter plant, with longer and more slemiler

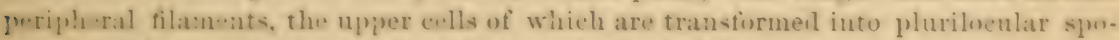
rancia. We have only examined dried specimens of this species.

C.LST.LfNEA, (Derb. \& Sol.) Thuret, ememel.

(In honor of Louis Castagne, a French botanist.)

Frombls and uniloenlar sporangiat as in Mesogloia; plurilocular sporangia formed by outgrowths foom the uppermost cells of the peripheral filaments.

C. vincscexs, (Carm.) Thuret. (Mesogloiu rirescens, Carm., in I'hỵe. Brit.; Ner. Am. Bor., Vol. 1, I'l. 10 b; Am. Sei. Nat., Ser. 3, Vol. 14, I'l. 27.) Pl. 7, Fig. 1.

Fromls filiform, gelatinous, three inclues to a foot and a half long, axis clothed with numerous, irregular, flexuous branches, ultimate branches short, given off at wide angles; fronds at first solid, becoming fistuJous; peripheral filaments slender, clustered, recurred or incurved, eylindrical or only slightly moniliform, cells cllipsoical, .015-20 $0^{\text {mam }}$ in diam eter; unilocular sporangia oroidal or rhombic orjate; plurilocular spo- 
rangia siliculose, composed of three to six cells, formed from the terminal cells of peripheral filaments, often secund on the upper side.

On sant-covered rocks and algæ at and below low-water mark.

Wood's Holl, Nahant, Gloucester, Mass.; Portland, Maine, Mr. Fuller; Europe.

A species which is rather common in the spring months, but which disappears with ns about the 1st of July. The fronds are more slender than in M. vermicularis, but when dried under too great pressure, or when allowed to remain some time in fresh water, they somewhat resemble that species. The distinction is best seen in the peripheral filaments. Those of M. vermicularis are shorter, decidedly clavate, less curved, and are formed of spheroidal cells. In $C$. virescens the 5 are longer, more nearly cylindrical, recurved, and formed of ellipsoidal cells. The number and size of the plurilocular sporangia vary very much.

C. Zoster A, (Mohr.) Thuret. (Myriocladia zosterce, Ag.-Mesogloia vermicularis, var. zosterc, Kiitz., Spec. Alg._.I. virescens, var. zosteri. cola, Harr., Phyc. Brit., Pl. 82.-M. zosterc, Aresch., in Ner. Am. Bor., Vol. I, p. 127, Pl. 10 a.) Pl. 7, Fig. 2.

Frouds filiform, gelatinous, three to eight inches long, subsimple, furnished with a few short, remote branches, given off at wide angles; peripheral filaments erect, rather rigid, cylindrical below, moniliform above; cells spheroidal, .02-4 ${ }^{\mathrm{mm}}$ in diameter; unilocular sporangia ovate; plurilocular sporangia siliculose, composed of three to six cells, usually forming dense tufts on the upper part of the peripheral filaments.

On eel-grass.

\section{Wood's Holl, Gloucester, Mass.; Europe.}

A small species with vers few branches, which, although it has been by some consiciered a variety of $C$. virescens, is sufticiently distinct both in its microscopic structure and the season of growth. C. virescens is a spring form, which disappears in early summer, while $C$. Zosterce, at least on our coast, occurs in summer and autumn. The appearance of the peripheral filaments is different in the two species. In C. virescens they are slender and curved and in $C$. zosterce rather stout and erect and more densely packed together, in this respect resembling $M$. vermicularis, in which, however, the filaments are distinctly clavate and moniliform, and do not produce plurilocular sporangia at the extremity. A section of the frond of a well-developed $C$. virescens shows a circle of roundish cells around a central cavity and on the outside a series of branching filaments, which end in the proper peripheral filaments and sporangia. In C. Zosterce there is also a circle of cells surrounding a central cavity, but the peripheral filaments seem to be given off directly from the circle of cells. The figure in the Nereis Am. Bor. does not correctly represent the structure of $C$. Zosterce, for the clusters of peripheral filaments are not outgrowths from special colored filaments, but from the uncolored cells. American specimens agree perfectly with the specimens of Mesogloia zosterce, No. 100, of Areschoug's Alg. Scand.

\section{Family RALFSIE $\mathbb{E}$.}

Fronds horizontally expanded, sometimes crustaceous; fructification in raised spots (sori), composed of few-celled club-shaped paraphyses and spheroidal unilocular sporangia. 
RALFSIA, Berkeley.

(In honor of John Ralfa, an English botanist.)

Fronds olive-brown, forming that eoriaceous or crustaceous expansions of indefinite extent, composed of a single horizontal layer, from which arise short vertical filaments, which are firmly united to one another so as to form a solid parenchymatous structure; fruit seattered over the surfice of the fronds in spots (sori), which are composed of club-shaped, several-celled paraphyses, at whose base are borne the unilocular sporangia; hairs arising from erypts in the frond; plurilocular sporangia unknown; growth peripheral.

I Eemus emtaining only about half a dezen spereins. In its mode of growth then fromil resermbles that of Myrimema, but the vertical filanents are not free, as in that

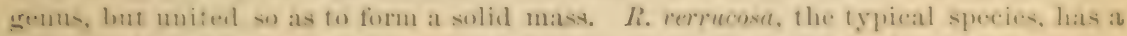

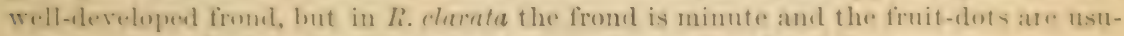
ally conthent, so that the species has by sone been placed in Myrionema.

R. vkiktoosı, Aresch. (R. deusta, Berk.; Phỵc. Brit., P'l. 9s.)

Fronds licheniform, alherent throughout, crustaceous or membranaceons, at first orbicular, at length becoming indefinite in outline, one to six inches in diameter, zoned and irregularly tuberculated, the newer lohes overlapping the older; sori seattered; paraphyses .06-12um long, disate, few-eelled: unilocular sporangia oroid or pyriform, .035- long by .019

Common on rocks in pools at half-tide from Sahant northward; Enrope.

A homely, dark-colored species, which has more the habit of a lieleen than an alea.

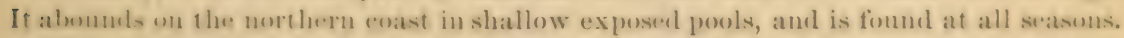
At tirst the crusts atre of small size and athere clesely to the rocks, but afterwarels, as they inerease in size, they become lobulated and rough and are easily detarehed. The speries, coutrary to the statement of Janezewski, is furnished with tufts of hairs at. certain seasums of the year. It maty occur also sonth of Cape Coul, hut, if so, it must be in a reduced form.

R. DEusta, J. Ag.

Fronds lieheniform, membranaceous, attached at center, margin free, irregularly orbienlar, with overlapping marginal lobes, marked with concentric zones and with radiating striat; spores?

At low water mark.

Eastport, Maine.

A larger and more foliarmus species than the preceding, lweing alout .25-3umm in thicknes. Inoth the concentrie zones and radiating strial are well markesl, and the

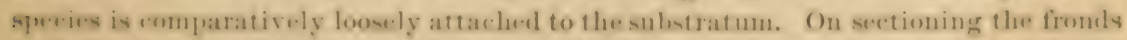
of li. deusta, the colls are seen to be arranged in lines which eurved upwards and downwarkls from a medial plane, white a section of the frond of R. rerrucusa shows thes colls arrangerl in lines which curre upwards from the attached hase. 
R. Clavata, (Carm.) Crouan, Florule du Finistère. (Myrionema clara. tum, Carm., in Phyc. Brit., Pl. 348.)

Fronds thin, forming closely adherent crusts or coriaceous expansions, at first orbicular and afterwards irregular; paraphyses clavate, rather uniformly diffused orer the frond; unilocular sporangia prriform, $.06-7^{\mathrm{mm}}$ broad by $.15-.18^{\mathrm{mm}}$ long, attached to the base of the paraphyses.

On stones and wood work

Eastport, Maine; Wood's Holl, Malden, Mass.; Europe.

A small species, whose position is doubtful. It was placed by Harvey in Myrionema, from the trpical species of which it differs in having a frond composed of several layers of horizontal cells. By Cronan it was placed in Ralfsia, but the erect filaments rather resemble the paraphyses in Myrionema. In short, the species may be said to be a Ralfsia with diffuse fructification and slightly dereloped frond, or a Myrionema with an excessively developed basal portion. American specimens resemble perfectly the No. 56 of Crouan's Algues Marines du Finistère. The alga described by Areschoug under the name of Lithoderma fatiscens bears a striking resemblence to the present species. The species is much smaller and thinmer than $R$. verrucosa, not exceeding on the arerage $.15 \mathrm{~mm}$ in thickness, and covers stones and wood work at Eastport, sometimes in company with $R$. verrucosa. Further inquiry will probably show that the plant is common along the whole coast.

\section{FAMILY ASPEROCOCCE E.}

Frouds tubular or compressed, usually simple, occasionally branched; fructification in external scattered sori, composed of cylindrical fewcelled paraphyses and spherical unilocular sporangia.

\section{ASPEROCOCCUS, Lam.}

(From asper, rough, and коккоs, a berry.)

Fronds olive-brown, simple or tranched, hollow, composed of a few layers of cells, those of the interior being larger and colorless, those of the surface smaller and colored; fruit exterual, scattered in spots (sori) over the fronds; sori composed of paraphyses and unilocular sporangia, which are formed from the superficial cells of the fronds; paraphyses numerous, cylindrical or club-shaped; unilocular sporangia globose, sessile betreen the paraphyses; plurilocular sporangia unknown; hairs tufterl, arising from the superficial cells; growth of fronds basal.

The genus Asperococens is distinguished by the external scattered fruit, consisting of paraphyses ant unilocular sporangia. In the Nereis Am. Bor. it was placed by Harvey in the order I Dictyotecer, lut the fructification in that order is now known to be very difierent. The gemus comprises a small number of species, which are widely diffused, although as yet only one has been found on the New England coast. The Asperococci resemble, to a certain extent, species of Phyllitis and Scytosiphon, but are easily distinguished by the fruit, which is almost always present. Plurilocular sporangia are unknown in the true Asperococci, and the old $A$. sinuosus, which is found in Florida and California, is considered by Bornet to belong to the genus Hydroctathrus, which has plurilocular sporangia of the same type as Phyllitis and Scytosiphon. A. compressus 
ani . A. bullosus are to he expeeted to oceur with us. The A. compressus of the I.int of tho Marine Alere of the Inited states, in the P'ree. Am. Aeal. Arts and Rejenees uf Mareh, $1-5$, is an error. The only specimen seen was collected at Giloncester by Mrs. Lusk, and proves to be a hleached and hownish fragnent of Malosucrion.

1. Eomxatrs, Grev.; Phyce. Brit., Pl. 194. (Pl. V, Fig. 3 )

Fromels gregarious, simple, attached by a small disk from two inches to a foot aml a half long, about half an inch in diameter, tapering at bise, often twisted but not eonstricterl, color a dingry brown, spotted with the very numerous sori.

\section{Attached to algie between tide-marks.}

\section{Common along the whole coast; Europe.}

A homely species, usually found in tufts four or tive inches long, and of alunt the sulistance of scylosiphon lomentarius, but nsually spotted with the mumerons fruit-alots. The diameter, which is nearly uniform throughout, is about that of a clay piprestem. 1. bullosus is much larger and more sack-like aud often decidedly constrieted.

\section{FaMiLy SPOROCHNEA.}

Fronds eylindrieal or tubular, branching, composed within of elongrated cuboidal cells, which become smaller and roundish at the surfiace; fructification in external scattered sori, composed of club-shaped filamentous paraphyses and sporangia; unilocular sporangia spheroidal; plurilocular sporangia cylindrical formed of a single row of cells.

Fronds solid, sori irregularly scattered ............. stilophora.

Fronds hollow, sori arranged in transserse lines ........ striaria?

STILOPHORA, Ag.

(From $\sigma \tau \iota\rangle, \eta$, a point, and

Fronds olive-brown, filiform, branching, solid, becoming hollow, com. posed internally of elongated colorless cells, which become smaller and colored towards the surface; fruit external, scattered in spots (sori) over the surface; sori hemispherical, consisting of club-shaped filaslentous parapliyses, at whose base are borne the sporangia; unilocular sporangia ovoislal; plurilocular sporangia cylindrical, formed of a single row of cells.

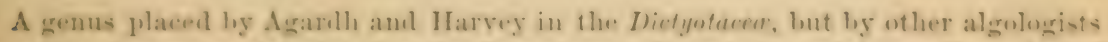
con-idered more nearly related to the speroetenee. It includes only a small number of speries, probahly not more than eight, and is readily recognized ly the external fruit in whieh the sporangia are lorme at the base of clarate few-erllem parapligses. The development of the frond has not been made ont, but at the tijes of the luanclues is a complicatod mass of nlaments emling in hairs like those of Ectocarpus, at w hose hase are borne a few short, incurved, monilifurm filaments. At a short distance below the apex of the fornt the moniliform filaments disappear and the surface appears to consist of romulish cells where not intermulted ly the numerous sori. It is probable that, 
as has been suggested by Janczerski in speaking of Sporochnus, the frond of Stilophora grows in a manner similar to that of Cutleria, which may be said to belong to the compound trichothallic type.

S. RHIzodes, Ag. (Sporochmus rhizodes, Ag., Spec.-Spermatochnus rhizodes, Kiitz., Spec.-Stilophora rhizodes, J. Agardh; Phyc. Brit., Pl. 70; Amn. Sci. Nat., Ser. 3, Tol. XIV, P1. 28.) (P1. V, Fig. 4, Pl. VI, Fig. 2.)

Fronds attached by a disk, filiform, solid, becoming somewhat fistu. lous, six inches to two feet long, branching subdichotomously, destitute of distinct axis, branches becoming attenuated, ultimate dirisions erect; sori very numerous, scattered irregularly orer the frond; paraphyses fer. celled, clarate, somewhat incurved ; unilocular sporangia oral ; plurilocular cylindrical.

Tot uncommon at rarious points in Vinesard Sound and Long Island Sound on algæ and eel-grass below low-water mark.

The present species is sometimes fond at the base of eel-grass and the larger algr, lut it is more commonly found in entangled masses a foot or two long washed ashore in sheltered bays after a heary blow. The determination is not altogether satisfactory, for our plants are generally coarser than the European forms of the species. Nor do they correspond to S. Lyngbyei, which is coarser and more tubular, and has finer ulti. mate branches and sori which are somewhat remote and arranged in transrerse hands, if we follow Harrey's description. Another species, hardly coming within our limits, was found by Bailey in the Chesapeake aud referred by Harvey, with considerable doubt, to S. papillosa, Ag.

\section{STRIARIA, Grev.}

(From stria, a ridge, referring to the arrangement of the sporangia in transrerse lines.)

Fronds attached by a disk, tubular, branched, cells of the interior large, roundish, of the exterior smaller and subrectangular; fruit conconsisting of sporangia (or spores?), arranged in transrerse lines.

A genus whose position is very doubtful, because the structure of the fruit is not sufiticiently well known. By most writers it is placed in the Dictyotacer, but it is not certain that the typical species, $S$. attenuctu, possesses the peculiar antheridia and tetraspores of that order. According to Areschoug, there are two forms of fruit, one immersed, as in Punctaria, the other external, as in Asperococcus.

S. атtenunta, Grer., Phyc. Brit., Pl. 25; Ner. Am. Bor., Vol. III, Suppl., p. 123.

Fronds a few inches to a foot loug; branches usually opposite, attenuated to a fine point.

Flushing, L. I., Bailey.

The ouly American specimen known is that mentioned by Harrey in the Supplement to the Nereis Am. Bor. as having been found at Flushing, L. I.

\section{FAMILY LAMIINARIEA.}

Fronds large and coarse; species on our coast usually attached by root-like processes, and with a stipe and expanded lamina, in one genus 
cylindrical; fructification in broal bands or large irregular spots, or oceasionally evering the whole surfice of fromd, composed of large broadly elavate or wedge-shaped pataphyses and oval uniloeular sporangia.

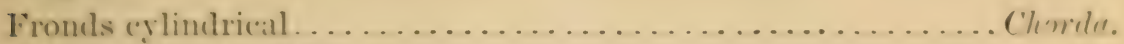
Fronds with a midrib.

Fronds perforated with holes .................... Agarum.

Fromds entire, with lateral leatets at the hase of lamina....Alaria. Fronds destitute of midrib.

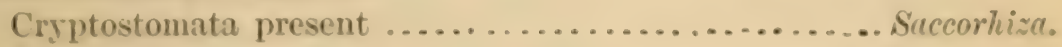

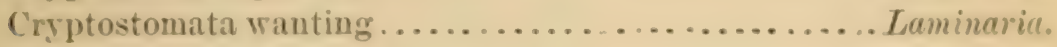

CIIORDA, Stack.

(From chorda, a string.)

Fromls olive-brown, attached by a disk, simple, eylindrical, hollow. with diapluragms at intervals; cells of tubular portion elongateel, hexagonal in section, lined on the inside with filaments, which at intervals are woren together so as to form the diaphragms; whole surface of the frond (dothed with emeate-clarate cells (paraphyses), which form a cortieal layer; unilocular sporangia ellipsoidal, situated between the garaphyses, growth basal; plurilocular sporangia unknown.

A small genus, concisting of three or four species, which are by some writers platerl in the Chor l triaten and hy others in the Laminariaced. The typical species, $C$. filum, may be rerardenl as the lowest representative of the Laminariacer, inasmueh as it hat the losal momle of growth and the unicellular paraphyses of that order, but a simijle fond in which there is no distinetion of stipe aud lanina. See, also, remarks umber Scytosiphon.

C. Flly, Linn. (Scytosiphon filum, Ag.-Chorda filum, Phye. Brit., I'l. 107: Annales des siciences, Ser. 3, Vol. XIV, Pl. 29), Figs. J-10.) Pl, VI, Fig. 1.

Fronds gregarious, cartilaginous-lubricous, quarter of an inch in diamreter, from one to twelve feet long, attenuate at base, densely clothed with hyaline hairs; paraphyses cuneate-clavate, slightly longer than the sporangia and overlapping them.

On stones at low-water mark and below.

Common along the whole coast; Europe.

At once recomized by its cord-like appearance. The early form, which is densely covered with hairs, constitutes the C. tomentesa of some writers. Areschong, however, consiclers that the true $C$. tumentosa of Lyngbye is distinet, and characterized loy its chongatem liuear paraphyses, which are searely as long as the sporangia, which rijuen rally in the seasm, while these of $C$. filum ripen in the latter part of summer and atutuun. 


\section{LAMINARIA, Lamx.-Devil's Aprons.}

(From lamina, a plate.)

\section{Fronds attached by a branching base,* stipitate, stipe expanding into} a ribless entire or laciniate lamina ; fruit forming bands or sori in the central part of the lamina, consisting of unicellular paraphyses and unilocular sporangia densely packed together; crsptostomata wanting.

A genus comprising not far from twenty-five species, which inhabit principally seas in high latitudes. They all grow in pools at low-water mark and in deep water, and some attain a very large size. The limits of the genus are well fixed, but the same can by no means be said of the species, with regard to which writers differ very much. The difficulty arises partly from the fact that the species lose some of their characteristic marks in drying, so that the study of herbarium specimens is unsatisfactory, but still more from the fact that the species rary greatly in outline and habit according to the season and the place of growth, whether at an exposed or sheltered coast or whether submerged or partly exposed at low tide. In general, the species may be classed in two groups, those in which the frond is ribbon-like, that is, long in proportion to the breadth and not split up into segments, and those in which the frond is proportionately broader and fan-shaped and, except when young, laciniate. To the former group belongs the $L$. saccharina of older writers, to the latter $L$. digitata, and it is with regard to the extent to which subdivision shall be carried in the two cases mentioned that recent writers differ very widely. Our species have not been sufficiently studied in situ to warrant us in giving the determinations with any degree of confidence. More information with regard to their winter condition is very much needed. The most detailed account of the Laminaria of the eastern coast is to be found in the paper of De la Pylaie in the Annales des Sciences Naturelles, Ser. 1, Vol. IV, 1821, entitled "Quelques observations sur les productions de l'île de TerreNeuve, et sur quelques algues de la côte de France appartenant au genre Laminaire." The article is accompanied by a plate in which is sufficiently well shown the habit of our common species. The same writer in 1829 gave a more extended account of his collections in the "Flore de Terre-Neure et des 1les Saint Pierre et Miclon," an inconplete work comprehending the Laminariacece and Fucacese, of which, howerer, the plates were never published. The species of De la Pylaie have not been accepted without question by algologists, and all agree that he was too liberal in the formation of new species. Harrey ignores the greater part of them in the Nereis. Agardh and Le Jolis gire them a more respectful consideration, and the former especially is inclined, in his paper on the Laminariacece and Fucacese of Greenland, to admit sereral of De la Pylaie's species. In the present case we do not feel at liberty to make use of the notes with regard to American forms which have been kindly furnished by European correspondents, but must content ourselves with a superficial account of the perplexing forms of this exasperating genus, adding that the identity of our forms with those of Europe is not in all cases proved.

Of the species of Laminaria given in the Nereis, L. fascia in now placed in Phyllitis ; $L$. lorea and $L$. dermatodea refer to the same plant, which is now placed in Saccorhiza; $L$. longicruris is still kept as in the Nereis; $L$. saccharina and $L$. digitata are kept with limitations; and L. trilaminata is, as Harvey suspected, merely an abnormal winged form of some other species, corresponding to the trilaminate condition mentioned under Agarum Turneri.

The marks used in distinguishing the species are the arrangment of the root-fibers; the structure of the stipe, whether solid or hollow, whether provided with distinct carities containing mucus (muciparous glands) the shape of the lamina, more particu-

* $\Lambda$ few species, as L. solidungula, Ag., have a disk-like base, and L. scssilis, Ag., including $L$. apoda, Harv., found on our west coast, has no stipe properly speaking. 


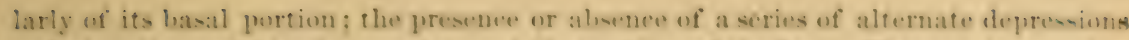
and elevations w ithin the margin : and the pmeition of the frait. The growing portion of the laminarier is at the hase of the lamina, and the apex of the stipe and the ohe

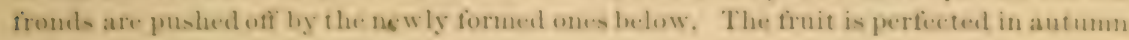
and winter.

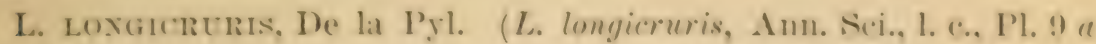
and b; Plıye Brit., 1. 339); Ner. Am. Bor., Vol. I, P'l. 6.)

Exs-Alga Am. Bor., Farlow, Anderson \& Eaton, No. 117.

Fronels solitary or gregarious, attached hy numerous long. slender, branching fibers: stipe six to twelve feet long, one to two inches thick, slender and solid at the base, becoming hollow and inflated at the middle and upper part, contracted at the apex; lamina orate-lanceolate, fire to twenty feet long, two to three feet broad; marein very wary, within the margin two rows of clepressed spots; fruit forming a continuous band in the center of the frond: color lightish brown; sulstance rather delicate.

Common in deep water, and at Eastport at low-water mark.

From Nahant, Mass, northward; North Atlantic and Arctic Oceans.

A striking species, easily recognized when in typical condition, but unfortunately variable, though not so much so as our other species. The root-fibers are long. rather siender, and much hranched. The stipe is slender at the hase, but expands gradually nywarls until it is at times two inches in diameter. The greatest diameter is abont two-thirds of the way up the stipe, which is then contracted, sometimes quite suddenly. When yonng and only a few inches long, the center of the stipe is filled with a solic mass of delieate filaments, but it soon becomes hollow. When torn from their attarhments by storms, large specimens, in consequence of the hollow stipes, float in a peculiar way, the upper part of the stipe projecting above the water like an ellow and the lamina dipping below the surface. The lamina is, in comparison with the stipe, shorter and broader than in our other species. This is especially the case in young speeimens, where the stipe may be several times longer than the lamina. In mature plants, however, the comparative length of the lamina varies very much with the place of growth. The present speeies has never been certainly known to occur south of Cape Corl. Specimens resembling L. saccharina, but with hollow stipes, have luen collewted in Long Island Sound. Whether really belonging to $L$. longicruris is doubtful, and the subject requires farther investigation.

\section{SACCHARINA, (Linn.) Lam.x.?}

Frond attached by numerous branching fibers; stipe solid throughout, terete, somewhat swollen in the mislde, three inches to four feet long; lamina elongated. lanceolate, fusiform or cuneate at base, three to thirty feet long, six to eighteen inches wide; margin wary, a row of depressions on each side of lamina; fruit forming a central band.

Var. PIYllits, Le Jol. (L. phÿllitis, I'hye. Brit., I'l. 192.)

Fronds small, lamina thin, margin slightly wary, base of lamina fusiiurm. 
Var. Caperata, (De la Pjl.). (L. caperata, Ann. Sci., I. c., Pl. 9 c.)

Stipe long in proportion to the lamina; lamina thick, one to two feet broad, cuneate at base.

Common on stones at low-water mark along the whole coast; var. caperata common north of Cape Cod.

In the present species we include all the New England forms which have a solid stipe and undivided lanceolate or orate-lanceolate frond. It is very probable that two, or possibly three, really distinct species are thus united, and it is also doubtful whether any of our forms are the same as $L$. saccharina of Europe, as limited by recent writers. Clearly to distinguish them is, however, at present out of the question. In going northward the forms here included become broader, and the base of the lamina is more frequently obtuse, and possibly the extreme forms should be referred to L. latifolia, Ag. The exact determination of the New England forms referred to L. saccharina cannot be successfully undertaken without an examination of European herbaria. Probably we have most of the forms described by De la Pylaie in the Flore de Terre-Neuve, but that writer has not displayed a commendable caution in the description of new species; and as European botanists differ as to what species the forms of De la Pylaie are to be referred, American botanists would not help the matter by pretending to give accurate determinations. De la Pylaie says that at Newfoundand $L$. saccharina does not occur, but is replaced by $L$. longicruris. The statement is singular, since, from De la Pylaie's own description, L. caperata closely resembles $L$. saccharina; and if any species may be said to replace $L$. saccharina, it is $L$. caperata, rather than the abundantly distinct $L$. longicruris.

L. Digitata, (Turn.) Lamx. (L. digitata, Ner. Am. Bor.-L. steno. loba, De la Pyl., Ann. Sci. Nat., l. c., Pl. 9 k.)

Exs.-Algæ Am. Bor., Farlow, Anderson \& Eaton, No. 119, sub. nom. L. flexicaulis.

Fronds attached by fibers, which are often arranged in whorls; stipe solid, stout, one to five feet long, more or less round below, compressed abore, destitute of muciparous glands ; lamina at first oval or lanceolate, afterwards split into digitate segments, two to six feet long, one to three feet wide; base fusiform or ovate; fruit in dispersed patches on the segments.

\section{Montauk, L. I.; Gay Head, Mass. ; and common north of Cape Cod.}

With regard to the limits of $L$. digitata a difference of opinion prevails; and in the present case we have retained, without criticism, the older name to designate the common digitate form of our coast. Of the two species described by Le Jolis it is probable that we have $L$. flexicaulis comprehended in the present form. The species is common with us in pools at low-water mark and below. The stipe varies considerably in length, according to the place of growth, and when well developed is stout and much compressed above, so that it projects rigidly above the surface of the water at low tide. The lamina is usually more or less fusiform at the base, but is sometimes oval, and the segments vary considerably, sometimes being very numerons.

L. Platrmeris, De la Pyl., Ann. Sci. Nat., l. c. Pl. $9 i$.

Fronds attached by stout, irregularly placed fibers; stipe six inches to a foot long, solid, roundish, compressed, provided with muciparous 
glamis. passing abruptly into a broadly orate or cordate lamina, which splits un into an few broud segments; substance thick, color blackish.

Deep water.

Peak's Island, Matine: Gloncester, Mass.

Distinguisher fro:a the last loy its short, thick stipe, whim is furnished with moriparous glants, and which terminates abruptly in a brual, thiek lanina, which is

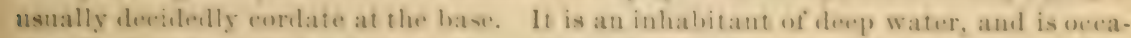
sionally found washed ashore in the autumn, hut is alwars much less common than the last specirs. Le Jolis considers that $L$. platymeris is, at least in part, the same as

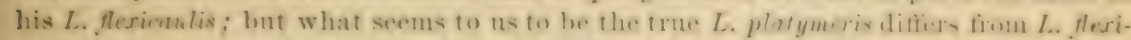

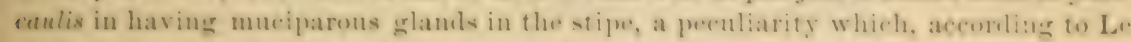
Jolis, is found in $L$. Cloustoni, but not in $L$. flexicaulis.

\section{SACCORHIZA, De la Pyl.}

(From баккоs, a sack, and irsa, a root.)

Fronds attached at first ly a disk-like base, from which are given off later a few short root-like fibers; stipe compressed, plane, gradually passing into a ribless lamina ; cryptostomata scattered on hoth sides of the frond; fruit as in Laminaria.

A genus cliffering from Laminaria principally in the form of the ha al attachment and in the pressence of cryptostomata on hoth surfices of the froml. The typical species, $s$. bullosa, not found on our coast, is attached by a sack-like base, and the frut is borne on the marginal upper portion of the stipe. In the present genus were at one time inchuled all the Laminarize whose attachment is discoidal rather than by branching root-like fibers. There are, however, forms still retained in the genus Laminaria, as $L$. solidungula, in which the base is a disk, and our own species S. dermatonleu, although in its younger stages attached by a clisk, soon has a series of short fibers, which, as the plant increases in size, !eecome branched. The cryptostomata are small pits sunk in the surface of the frond, from which arise groups of hairs, as in the Fucarea. They are visible to the naked eye in the young plants, lut disalpear with age.

S. Demiatodea, De la Pyl. (Laminaria dermatodea, De la Pyl., Am. Sciences, l. c., Pl. 9 g, non Agardh nec IIarves. L. Lorea, Ag. Speec; Harres, in Ner. Am. Bor.)

Exs-Algie Am. Bor, Farlow, Amlerson \& Eaton, Xo. 120.

Fronds usually gregarious, lase at first disienidal, afterwards with a whorl of short, thick, nstally simple fibers; stipe six inches to two feet long, compressed, gratually expantling into a thick, corjaceous-lanceolate or lance-ovate lamina, one to six feet long, six to eighteen inches wide, at first entire, lout afterwards torn above into several segments: fruit in scatteres sori, which become conflnent at the lase of the firond; paraphyses narrowly club-shaped, about .15, long: sporangia .12em long ly. $.02 \mathrm{~mm}$ broad.

From Marblehead, Mass, northward.

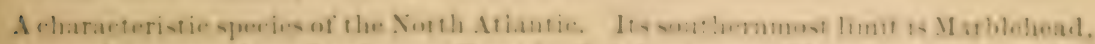

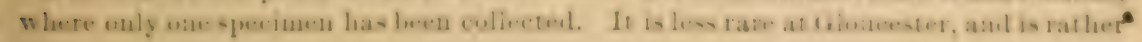


common on the coast of Maine, but much less abundant than other Laminario. It is the most easily recognized of our Laminarice, in spite of its great variability in outline. The substance is more tough and leathery than any of our other species and the margin is thick and never wavy. At Eastport it is found in deep pools, but elsewhere it is an inhabitant of deep water. As usually seen washed ashore it resembles one of tho digitate forms of Laminaria, for it is usually torn into segments, and not rarely split to the very base. It is at once distinguished from our digitate Laminarice by its uniformly flat stipe, very short root-fibers, and cryptostomata. In most cases the stipe expands very gradually into the blade, but occasionally in old specimens the base is cordate. The fruit is found in the autumn and winter. In the specimens which we have ex. amined the paraplyses were very narromly club-shaped and colored to the tip, being destitute of the hyaline tip found in Laminaria.

\section{AGARUM, (Bory) Post. \& Rupr.}

(From agar-agar, a Malayan word referring to some edible sca-weed.)

Fronds stipitate, attached by a branching root-like base ; lamina perforated with roundish holes; stipe prolonged into a midrib; fruit scattered in patches (sori) over the fronds, consisting of club-shaped, onecelled paraphyses and ellipsoidal unilocular sporangia; plurilocular sporangia unknown.

A genus differing from Laminaria in having the lamina perforated with round holes and furnished with a distinct midrib. It includes four described speeies, which differ in the size of the perforations, in the shape of the lamina, and the prominence of the midrib, characters which an observation of our common species shows to be very variable. The species iuhabit the Arctic Ocean, the northwestern shore of the Atlantic, and the North Pacific. The New England form, A. Turneri, also occurs in the Pacific, extending as far south as Japan, and, on the west coast, $A$. fimbriatum, Harv., considered by Agardh to be the same as Fucus pertusus, Mertens, extends as far south as Santa Barbara, Cal.

A. Turneri, Post. \& Rupr.-Sea Colander. (Fucus cribrosus, Mertens.-F. agarum, Turner, Hist. Fuc., Pl. 75.-Laminaria agarum and $L$. Boryi, De la Pyl., Flore de Terre-Neuve-Agarum Turneri, Post. \& Rupr., Illustr. Alg., Pl. 22 ; Ner. Am. Bor., Vol. I, Pl. 5.)

Exs.-Alga Am. Bor., Farlow, Anderson \& Eaton, No. 112.

Base much branched, stipe two inches to a foot long, cylindrical below, flattened above and prolonged into a distinctly marked midrib ; lamina menbranaceous, one to four feet long, ovate-oblong, cordate and much crisped at base, margin wavy; perforations rery numerous, orbicular, irregularly scattered with a smooth or wary margin; fruit in irregular patches in the central part of the frond; sori .05-6 $\mathrm{mm}$ in thickness; paraphyses club-shaped, colored below, expanded and hyaline at the top; sporangia narrow, ellipsoidal, .035 $5^{\mathrm{mm}}$ long by .012 $\mathrm{mm}$ broad.

Common from Nahant northward in deep water and at Eastport in pools; North Pacific.

One of the curiosities of our marine flora, which is washed ashore from deep water at the southern limit of its growth, but farther north grows in pools at low-water mark. 


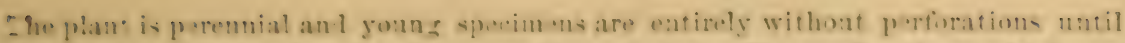
they hase attained a length of two or three imches. The prerforations, which are supposed by the fishermen to be the work of anima!s, are formed in the lewer part of the frond and increase in size as they grow ohler, so that the perforations are larger in

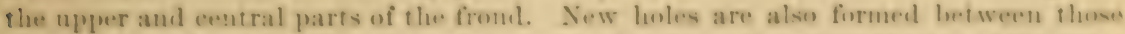
already formed, so that there is a difterence in size depending upun the age of the hoshes in all parts of the frond except the hase. The formution of the lowes begins hy an clevation of small portions of the froml, which appears as if some small point like that of a perecil had been pressed against it ; at hongh the fromd ruptures circularly and the hute formed is minute and above the plane of the fromd. The margins of the large holes are offen wavy, and when dried with a slight pressure the waviness becomes so markind as to lead one to suppose that the spereimens leelong to a dint inct speedes. The midrib raries comsid rably in brealth and oceasionaly it grows out, forming a laminic at right angles in the frond. The usual perforations are foum in the additional lamina, which sometimes grows to be as large as the original lamina. The fruit of Agarum, which is ineorrectly figured in the Nereis as having a form of tetraspores, resembles vety clusely that of Laminaria. The species apparently does not hear fruit on the Massachusetts coast, at least we have never heen able to find any: hut at East purt the fruit is formeal as early as september. The sori are seattered irregularly oser the central part of the froml and are most easily seen after the fromd has been ont of the water a short time. The sori are not so thick as in Alarin and Lamimarin and the faraphyses do not have so prominent a hyaline extremity as in these genera. Harvey states that the lamina are sometimes ten or twelre foet long. lut this is probably an orerestimate.

\section{ALARIA, Grer.}

(From ala, a wing.)

Fromls attached by a branching root-like base, stipitate, membranaceous, with a distinct midrib; fruit borne in special lateral leaflets below the lamina, consisting of club shaped, one celled paraphyses and ellip. soidal uniloeular sporangia; plurilocular sporangia unknown.

A genus readily known by the small, ribless leatlets given off from the stipe below the lamina, in which the the fruit is borne in the antumn. The grenus inhalsits the eolder waters of the northern hemisphere and the species sometimes attain a length of fifty foet. The number of species does not exered half a dozen, and the specifie marks. sarh as the shape of the midrib, the lateral leaflets, and the base of the lamina, are variable, so that all the species cannot be sainl to be well marked.

1. esculexta, Grer. (A. esculenta, Phye. Brit., Pl. 79.-Laminarin muserfolia, De la Pyl., Ann. Sci. Yat., Ser. 1, Vol. IV, Pl. 9 d.-L.lineuris, De la Pyl., l. c, Pl. 9 f.)

Stipe cylindrical-compressed, from four inches to a foot long, a quarter to half an inch wide; millrib solid, scarcely willer than the stipe; lamina one to ten feet long or even longer, two to ten inches from side to side, decurrent on the stipe, margin wars; fruetiferous leaflets numeronse, shortly stipitate, three to eight inches long, half an inch to two inches broad, linear-ovate or linear-spathulate.

Var. Latifolia, Post. \& Rupr. (Laminarin Pylaii, Porry, in Flore 
de Terre-Neure.-Alaria Pylaii, Ner. Am. Bor.-A. esculcnta, var., Post. \& Rupr., Illustr. Alg., Pl. 18.)

Base of lamina cuneate, fructiferous leaflets obovate-spathulate.

Common on exposed coasts at low-water mark and below, from Nahant northward. The variety at Eastport, Maine, Northern Europe, and Pacific coast.

As yet no species of Alaria has been found south of Cape Cod, although it is probable that they occur at exposed points like Gay Head and Montauk. In the Annales des Sciences, De la Pylaie inentions three varieties of A. esculenta-platyphylla, taniata, and remotifolia-as occurring at Newfoundland, and in the Flore de Terre-Nenve he makes two new species-Laminaria musafolia, including $L$. esculenta, var. platyphylla and var. remotifolia, and $L$.linearis, including $L$. esculenta var. teniata. These species are characterized by the different forms and position of the fructiferous leaflets, which, it must be admitted, are so variable and so constantly pass into cne another, that De la Pylaie would have done better in retaining them all as forms of one species. Laminaria Pylaii, Bory, founded on a single specimen brought by De la Pylaie from Newfoundland, also seems to be merely a variety of $L$. esculenta, in which the lamina is cuneate at the base. At Eastport the broader forms are common, and one sees all stages from decurrent to cuneate laminæ. Agardh refers to L. Pylaii, Bory, the Alaria esculenta var. latifolia, of Postels and Ruprecht, whose plate represents excellently the extreme forms found at Eastport. The present species is used as food in Scotland and Ireland, where it is called badder-locks, henware, murlins, and also in Iceland, but it is not eaten with us.

\section{ORDER III. OOSPOREA, Sachs.}

Male organs (antheridia) composed of sacks borne on simple or branching filaments, sometimes sessile, containing motile antherozoids; female organ (oogonium) in the form of a sack, whose contents change into one or more spherical masses (oospheres), which are directly fertilized by the antherozoids and become oospores.

In the order Conjugatece there was a direct union of similar bodies called zoospores, and no clear distinction of male and female cells. In the Oosporex the males are smallmotile bodies (in algie), which directly impregnate the spherical masses of protoplasm, called oospheres, either before or after they have escaped from the mother-cell, the oogonium. As a result of the impregnation, a wall of cellulose is formed round what was before merely a mass of protoplasm, and the so-called oosphere becomes an oospore and capable of germinating. The marine plants of the order may be divided into two suborders, as follows:

a. Large olive-green plants, having the antheridia and oogonia in nearly closed sacks borne in a definite part of the plant; fronds foliaceous, often provided with air-bladders ................. FUCACE E.

$b$. Minute grass-green plants forming turfs or tufts; antheridia and oogonia naked, sessile, or pedicellate, borne laterally on the unicellular branching frond.................... VAUCHERIE 


\section{Suborder FUCACEE, C. Ag.}

Plants diecions or hermaphrodite, fruetifying organs horme in con. ceptacles or cavities lined with sterile filaments and opening outwards hy a narrow pore : antheridia in oroid sacks borne on branching threads and filled with minute antherozoids having two lateral cilia; oospores spherical, horne 1-s in a mother-eell. Marine plants of an olive-green color, attached by a disk-like base, fronds usually branching dichotomously, rarely intefinitely expanted, often proriled with air-blathlers and with errptostomata.

An orker characterized by the presenee of anthernzoids borme in sackis and by oospores, varying in the different genera fiom one to eight in a molher-eell, lwoth antheriblia and ouspores being contained in hollow conceptacles, which are problued either in definite parts of the fromd or on special loranches or rarely indefinitely seattered orer the froml. The fertilization in this order was first described loy Thuret in the Annales des Sciences, Ser. 4, Vol. 2. The fromds vary very much in the different genera. In Durrillav the froml resembles a large Laminaria, and from this simple form there are all degrees of complieation, until in Sargassum, the most highls dereloped genns, there are listinet stems, leaves, air-blablers, and hranching finctiferous receptacles. In high latitules the order is chiefly represented ly the common rockweeds, Fuci, which line the rocks between tide-marks, while in low latitudes the gulf-weeds, species of Sargassum, abound. The Southern Ucean abounds in curious and varied furms of this order, Australia being particularly rich in species. The New England coast is especially poor in representatives of the order, the genera Halidrys, Himanthalia. Pelcetia, and Cystoseira, common on the eoast of Europe, lueing entirely wanting with us. The frouds are dotted with small pits, called cryptontomata, from which grow tufts of hairs.

SYNOPSIS OF GENERA.

Fronds with distinct stems and leaves................ Surgassum.

Fronds without distinct stems and leaves-

Lamina provided with a midrib, receptacles terminal, continuous with

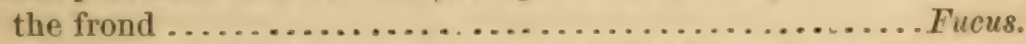
Midrib wanting, receptacles on special lateral branches.. Ascophyllum.

ASCOPHYLLUM, (Stackh.) Le Jolis, emend.

(From aøкos, a sack, and $\phi v \lambda$.ov, a leaf.)

Fronds attached by a disk, linear, compressed, destitute of a mirlrib, irrecrularly dichotomous, furnished with air-bladelers; receptiales on distinct, simple, lateral branches; spores four in a mother-erll.

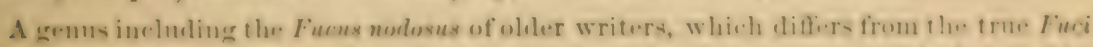
in having a linear fromel dentitute of a midrib amel spores in fonrs instead of in eights. The generie name Ozolluallia proposed loy Deeaione and Thuret, who were the tirst to

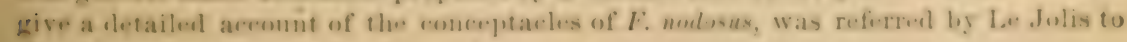
the older genus Ascophylla of Stackhouse.

1. xomostr, Le Jolis. (Fucus nodusus, L.; Plige. Brit., Pl. 1.5s; Ner. 
Am. Bor., Vol. I, p. 63.-Fucodium nodosum, J. Ag.-Ozothallia nodosa, Dcne. \& Thuret.-Ascophyllum nodosum, Le Jolis; Etudes Phrcologiques, Pls. 18-20.)

Fronds diøecious, one to fire feet long, coriaceous, compressed, subdichotomons, margin distantly toothed; air-bladders oblong, broader than the frond; receptacles ovoid or ellipsoidal, terminating short lateral branches, which are borne either solitary or clustered in the axils of the teeth.

Common between tide-marks from New Jersey northward; Europe; Arctic Ocean.

One of our most common species, ensils recognized by the large bladders in the continuity of the froud, which is thick and narrow and entirely destitute of a midrib. The fruit is found in lateral branches in winter and spring, and in June the receptacles fall off and are sometimes found in immense quantities corering the bottoms of tidepools.

\section{FUCUS, (L.) Dene. \& Thuret.}

(From фvкоs, a sea-weed.)

Fronds diœcious or hermaphrodite, attached by a disk, plane, costate, dichotomous, margin entire or serrate, often furnished with air-bladders; receptacles terminal, continuous with the frond; spores eight in a mother-cell.

In the beginning of the present century the name Fucus was used not only to designate all the plants included in the present order, but was applied to all marine algæ. Since that date the word has been used in a more and more restricted sense, and is now only applied to those members of the Fucacea in which the spores are in eights and in which the frond is plane and costate. In some of the species, however, the midrib is rather indistinct. Most of our species are very abundant and very variable, and older writers have described as species a good many forms which are now considered to be merely varieties. Hence the synonymy of the species is in confusion, although our species, none of which are peculiar to America, can be referred to definite European forms. The species described by De la Pylaie in the Flore de Terre-Neuve are most of them to be referred to older species. The New England species naturally fall into two different groups. In the first, of which $F$. vesiculosus is the type, the fronds are diœcious and the midrib distinct throughout. In the second, represented by $F$. evanescens, they are hermaphrodite and the midrib indistinct.

F. vesiculosus, L.; Phyc. Brit., Pl. 204 ; Études Phycol., Pl. 15.

Fronds diœcions, six inches to three feet long, stipitate, midrib distinct throughout, margin entire, often wars; bladders spherical or slightly elongated, usually in pairs; receptacles swollen, ellipsoidal or oval, often forked.

Exs.-Algæ Am. Bor., Farlow, Anderson \& Eaton, No. 109.

Var. LATERIfRuCtus, Grev.

Lateral branches, which bear the receptacles, narrow and densely dichotomously flabellate. 
Var. sph.terocanper, 1 g.

Ultimate divisions of frond repeatenlly forketl, bearing very numerous small receptacles.

Var. spiralis.

Fronds short and spirally twisted.

Everywhere common between tide-marks.

The varieties of this very common species are so mumerons that it is useless fo describe the greater part of them. The sonthermunst limit of the species on the eastern enast is, as far as known, the coast of North Carolina, where it is reported to have lewen collecteel by Rev. F. M. Forbes in Curtis's account of the botany in the Geological amel Natural History survey of North Carolina. Fucus birornix anul $F$. micophlylllus of De lit Iylaie appear to be merely forms of $F$. resiculusus. The speecies with which the present is likely to be confomeled along our northern coast is $F$. cromeserns, a broal plant, whose mildih is only distinct in the lower part of the frombl, and whose conceptacles are hermaphroclite, not dioreious, as in the present species. It fruits most alumblantly in autum: and winter, but the fructitication can be seen at any season of the year.

F. Cerayoides, L.; Phye. Brit., Pl. 271.

"Frond plane, coriaceo-membranaceous, linear-dichotomous, midribbed, without vesicles, margin very entire; lateral branches narrower than the principal divisions, repeatedly forked, level topped, bearing fruit at their apices; receptacles spindle-shaped or bifid, acute." (Ner. Am. Bor., Vol. I, p. 70.)

\section{New York, Agardh; Europe.}

The anthority for the exintence of this species on our coast is Araralh. Harrey hanl never sewn Aneriean sperimens, nor have we ever found any. The species, julging from herbarium specinens, resembles very chosely $L$. cexiculosus, enpecially var, laterifructus, lut is said to be thinner and to be destitute of air-bladelers. It inhabits ratleer brackish waters.

F. serrates, L.; I'hye. Brit., I'l. 47; Etudes I'hycol., I'ls. 11-14.

Fronds diacions, two to six feet long, midrib distinct throughout. margin serrate; hladkers wanting; receptacles serrate, tlattish, pointed.

Xewhuryport, Mass., Captain P'ile; Pictou, N. S., Rer. J. Focler; Enrope.

A very common spmeies of Europe, but very rare on our coast, being known in on!

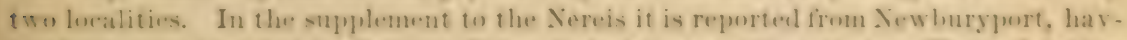

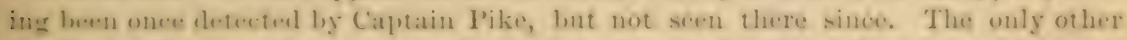
locality is Picton, where it was detected by Rer. J. Fowler, who sent specimens to

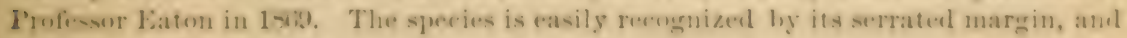
grows lower down in the water than $F$, resiculosus.

F. evavescexs, Ig., Icon. Ined., Pl. 13. (Fucus plufycurpus, in Farlow's List of the Marine Algat of the United states.)

Fronds hermaphrodite, one to two feet long, stipitate, midril, distinct below, but widening and scarcely visible in the upper part, margin broad, entire, somewhat wasy; bladers usually manting, when present much 
elongated ; receptacles swollen, broad, usually united in pairs, and sometimes with a small margin formed of the unchanged frond.

Exs.-Algie Am. Bor., Farlow, Anderson \& Eaton, No. 107.

Eastport, Maine; coast of Massachusetts; Northern Europe; Arctic Ocean.

A species apparently common north of Cape Corl, and at Eastport quite as common as $F$. resiculosus, for which it might be mistaken. As found with us, it is broader than the last-named species and is usually without bladders, and when these occur they seem more like irregularly inflated portions of the frond than spherical carities. The receptacles contain both antberidia and oospores, the latter occupring the base and the former the upper part of the conceptacle. The receptacles are broader and less swollen than in $F$. vesiculosus and are of ten in pairs, the pairs being united below. The whole plant is shorter, stouter, and more foliaceous than $F$. vesiculosus. The species as found in the Arctic regions is variable, and several forms have been described. The form which occurs at Eastport comes rery near the typical form. F. miclonensis of De la Pylaie is probably a small form of the present.

F. Furcatus, Ag., Icon. Ined., Pl. 14.

Fronds hermaphrodite, branching rery regularly dichotomous, stipitate, one to three feet long, midrib distinct below, scarcely visible above, margin narrow, rigid, entire; bladders wanting; receptacles flat, narrow, linear-fusiform, sometimes forking.

Exs.-Algæ Am. Bor., Farlow, Anderson \& Eaton, No. 108.

Peak's Island, Maine ; coast of Massachusetts north of Boston ; Northern Europe; Arctic Ocean; North Pacific.

A common and beautiful species on exposed coasts north of Boston. It is found lower down than $F$. vesiculosus, at the limit of low-water mark. The frond is narrow, tough, and destitute of bladders, and the branching very regular, almost flabellate. It is easily distinguished by the receptacles, which are not in the least swollen and are narrow and longer than in any other species, being sometimes four inches long. The color is dark. Our form corresponds perfectly to specimens from Spitzbergen. The species is less rarlable than most of the genus and is found at all seasons of the jear.

F. FIliformis, Gmelin. (F. distichus, L., in Farlow's List of the Marine Algæ of the United States.)

Fronds hermaphrodite, three to six inches long, flabellately dichotomous, stipitate below, midrib presen t but indistinct; air-bladders wanting ; receptacles linear-oblong, swollen, borne in pairs, sometimes forking.

In pools near high-water mark.

Nahant, Marblehead, Mass.

Our smallest species, found only in spring and in pools where the water is not very pure. Our form is the same as No. 201 of Areschoug's Algæ Scandinavicæ, from Finmark, which Agardh refers to $F$. filiformis. Whether $F$. distichus, L., is not the same as F. filiformis, Gmelin, admits of doubt. The present form seems to be the F. filiformis af the Flore de Terre-Neuve, mentioned under $\boldsymbol{F}$. distichus in the Nereis Am. Bor. 


\section{SARGASSUM, Ag.}

(From sargaso, the Spanish name for the gulf-weet)

Fronds attaled by a disk having branching stems, leares with a midrib and distinctly stallied air-bladders; fruit in spectal compoum branches; conceptacles hermaphrolite; spoes single in the mother-cell.

The mant highly organized and hy far the laremet grans of the Fucueer, of which at

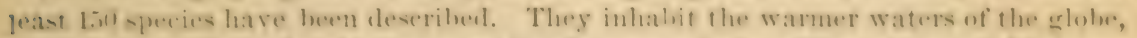
where they replace the Fuci. Anstralia, Japlan, and the auljacent eoast of Asia are

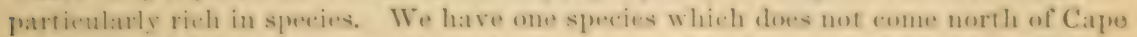
Cowl, hut which is common sonthwarl. The genus has leen sululivided hy Kiitring, but even with his limitation the species of Sirgassum aro vory unmerons.

s. voundRe, Ig. (Fucus natans, Turner's Ilist. Fue., I'l. ti, non Linn.-S. vulgare, Phỵc. Brit., Pl. 343.)

Frombls two to fire teet lomg, stem filiform, smooth, irregularly branching, leaves shortly petiolate, linear-lataceolate or oblomg-lanceolate, one to three inches long, a quarter to half an incls wide, sharply serrate, millrib distinct, eryptostomata numerous on both sides of the millrilı: air-blablers spherical, quarter of an inch in diameter, stallicel, arising fiom a transtormed leat, the upier part of which often remains as an appendage; stalks naked or slightly winged; receptacles filiform, branching eymosely, one to two inches long.

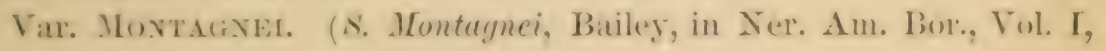
Pl, 1 a.)

Leares narrowly lincir, elongaterl, receptalcles two to four inches loner.

Ibelow low- Water mark in warm, shallow hage from Cape Coul southward.

In spite of its variations, with the exception of $S$. baceiferum, which is sometimes washed ashore, we have but one speceies of Surgussum on our coast. As usually finud, it is une slemiler in all its parts than the typical s. vulyare of the Wiest Indies, lum it is oreasionally fonml of the typical form. In var. Momlagmei, which is comumon, we have an extreuse form, in which the fruetifying branches are unch elongated, but ono sees all variations from short to long.

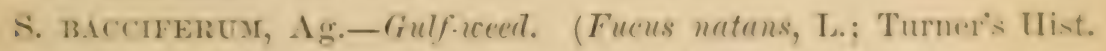
Fuc.. Pl. 47._N. baceiferum, Plıye. Brit., Pl. 109.)

Fromls six inches to a foot and a halt long, stems filitorm, smooth. leaves linear-lancenlate, two to four inches long, mirlrib distinct, rryptostomata usually wanting; air-bladders stallied, spherical, tipped with at filiform point ; receptacles short, eylindrical, forked.

Washed ashore at Bath, I. I., Mr. A. R. Tormg, and found tloating of the coast near the Gulf Stream; West Indies, and floating in the Atlantic.

The comumon Gulf-weenl, which grows aftachend in the West Indies, where it fruts, 
and which is found floating and infertile in the course of the Gulf Stream and in the so-called Sargasso Sea, between $20^{\circ}$ and $45^{\circ} \mathrm{N}$. and $40^{\circ} \mathrm{W}$. It is rarely washed ashore in New Eugland, but is frequently brought in by fishing vessels. It is said that there is a large mass of this sea-weed in the ocean not far from Nantucket, but there is no definite information on the subject. The species in its floating form is distinguished from the last by its narrower leaves, destitute of cryptostomata, its darker color, and denser habit.

\section{SUborder VAUCHERIEÆ.}

Comprising a single genus, Taucheria, whose characters are given below.

\section{VAUCHERIA, D. C.}

(Named in honor of Jean Pierre Vaucher, of Geneva.)

Fronds green, unicellular, composed of long, irregularly or falsely dichotomously branching filaments, monœecious or diœecious; oogonia sessile or stalked, containing a single oospore; antheridia either short oroid sacks or formed at the tips of branches, which are frequently spirally twisted; antherozoids very small, with two cilia; non-sexual reproduction by very large zoospores, which are covered with cilia, or by motionless spores formed at the ends of short branches.

The Taucherice abound both on our coast and in inland waters, and some species grow upon damp ground in gardens and meadows. They either form thick turfs of a dark-green color when growing in places which are not constantly submerged, or else extend in indefinite-shaped masses when growing where there is plenty of water. They are generally easily recognized at sight, and are known under the microscope by the long branching filaments of a deep-green color, destitute of cross-partitions except when the fruit is forming. Although very abundant on our shore, the species are littlo known, because the specific characters depend upon the fruit. The determination of sterile specimens is out the question, and, even when fruiting, dried specimens are of comparatively little value. A considerable number of species of Tancheria have been described, but as a great part of them have been described from inclividuals bearing the non-sexual spores only, recent writers, as Walz and Nordstedt, have reduced the number of species very much by omitting imperfectly characterized forms. Nordstedt admits nineteen species in Europe. The American species have never been critically studied. Specimens should be kept in fluid rather than mounted on paper, and sketches of the fruit should be made at the time of gathering. It should not be forgotten by the collector that some of the species are diøcious, and also that a species is not perfectly known unless the non-sexual spores are described as well as the oospores.

V. Tiuneti, Woronin, Beit. zur Kenntniss der Vaucherien, in Bot. Zeit., Vol. XXVII, p. 157, Pl. 2, Figs. 30-32.

Moucecious; filaments .03-8 ${ }^{m m}$ in diameter, forming short, dense turfs; antheridia sessile, oval, .0 $-^{\mathrm{mm}}$ broad by $.10-14^{\mathrm{mm}}$ long; contents of antheridia colorless; oogonia either sessile or on short lateral branches, obovoid or pyriform, inclined, .25-30 $\mathrm{mm}$ long by $20^{\mathrm{mm}}$ wide; oospores spherical, .15-18 $15^{\mathrm{mm}}$ in diameter, Jellowish brown; cell-wall rather thin; 
non-sexual spores (?) $.05^{m m}$ hroald by $.10-12^{\text {mur }}$ long, motionless, horme on short branches, which are at right angles to the main filaments, from which they break otr, allowing the spores to escape from the rupturent end.

Exs-Wittrock of Nordstedt, Alg. Scand., No. "2.s.

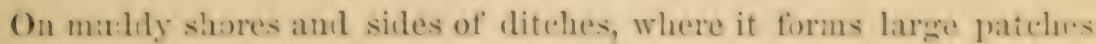
of a dark velvety green. Summer.

Woud's Holl, Mass, Eastport, Maine; Perth Imboy, X. J., Wulle: Europe.

This speries, which is apparently common on muldy shores of New lingland, agrees so well with the description and figure of Woronin, l. c., that there can lwe no dentet alont the identity of our plant with that of the Enropean coast. The nom-sexnal fruit was unknown to Woronin. At Wool's Holl we thumb what appeareil to loe th. non-sexual frut of the species. It consisted of oval spores, smaller than the on-jorr. borne at the tips of short hranches, which were giren off at right angles to the main filaments. The branches with the spores fall off, and the latter, after some time. esiape from the ruptured end of the cell. The spores are motionless and destitute of cilia, reminding one of the non-sexual spores in $\mathrm{V}$. geminata, Walz. During the four or fire days which we were able to watch them they underwent no chance. In th. sperimen of Wolle, ahove mentioned, similar bolies are foumb, but Nombtemlt thinks it probable that they beloner to a species difterent from $I$. Thuretii. He is lect to this conchision apparently from the fart that the filaments bearing the non-sexnal spores are rather smaller than those which hear the oospores and antheridia. In the WoollHoll specimens the filaments were, as a rule, somewhat smaller than those bearing the onopores: lnt the differenee is rery slight, and one sometimes finds oo-poriteron. filanents measuring only asmon in dianeter, while the non-sexual spore-lowaring tilaunents arerage from . (14-5wan in diameter. In one case we foumd an antherilium on flu.

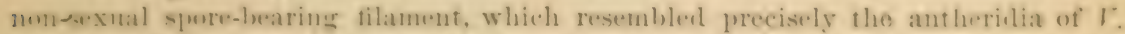

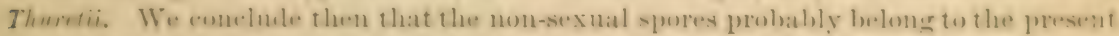
spmede, but the question repuires further examination. A speeimen of what apjears to the the same squeres exist in the enllection of the Boston society of Natnmal H:tory. It was colleefed ly Prof. J. W. Bailey from sone locality near New Yorli, and is labelled, in his own hand writing, $\Gamma$. velutina.

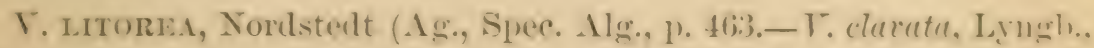

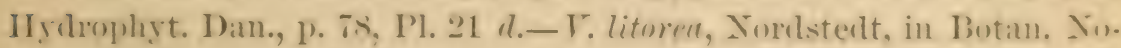
tiser., 1s.9, 1. 1s0, P'l. 2, Figs. 1-6.-F. piloboloides, Farlow, List of Marine Algre, 1876.)

Diucions; filaments densely tufterl, ratleer rigril, .10mm in mianeter ; antheridia?: oogonia cluh-shaperl, horne on a short sterile eell at the tips of short recurverl branches, .20ma broal by about ..3.5m long ; oospores

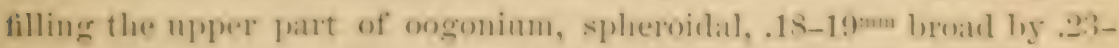

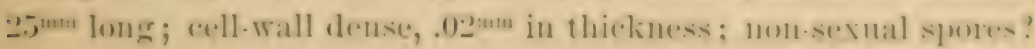

At low-water mark in the gravel.

Parker's Point, Woorl's Holl, Mass.; Enrope.

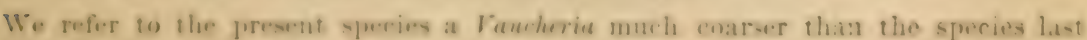
descriluel, which torms rather bristly tnfis of a dingy grem, from two to fiur inches high, in gravelly places. Only one specimen, collected in Angust, 1-i6, was in finit, 
and at the time, as there rere no antheridia, we hastil mon-sexual. It now seems probable that the plant is the T. litorea of Nordstedt, 1. c., a diœcions species. The species was common at Wood's Holl in August, 1879, but constantly sterile. The antheridia of $V$. litorea, Nordstedt, are long and cylindrical and borme on a short sterile cell at the tips of the branches. The antherozoids are discharged bs openings at the apex and sides of the antheridium. Our plant will be easily recognized by its habit and the recurved branches bearing the oogonia.

\section{ORdER IV. FLORIDEA.}

Algie of a reil or purple color; antheridia containing spherical, hyaline antherozoirls, which are without cilia; sexual fruit or erstocarps dereloped from a procarp, which consists of a trichogsue, at whose base is a trichophore, the spores formed either from the trichophore or the adiacent cells which co:mpos the carpogenic srstem; spores at maturity either naked or inclosed in a rericarp; non-sexual reproduction by tetrispores, bispores, aul seirospores; fromds filamentons, crustaceous, membranaceons, or irregularly expanded, varying from gelatinous to cartilaginous in substance, occasionally calcareous. Principally marine.

The Floridere, which are the sane as the Ihodospermere of Harres, include a large number of species, all of which have some shade of red. althongh it may be nearly black on the one hand or approach sha les of green on the other. In decay, howerer, the color becomes orange and finally green. It is not to be inferred, howerer, that all resl algie belong to the Floridere. There are a few Cyanophycere in which the color is pink. but in these species the frond is merely an agglomeration of red cells, each of which is practically a distiuct individual, whereas in the Floridece the cells are organically united, aud constitute a single plant. The structure of the frond in this order varies in the different genera, and we have forms which correspond closely to the frouls of the Phessporece, as, for instance, in Vemalion we have a frond which, apart from its color, is undistinguishable from that of Mesogloia, and so on. The non-sexial reproduction is by tetraspores, cells which divide into four parts-rarely by bispores or two-parted cells-and seirospores, or chains of oblong cells formed directly from tho branches. The sexual fruit, known as the crstocarp, is developed from a procarp, as has alreaty been explained. The division into suborders is founded principally on the ditferences in the çstocarpic fruit, the full development of which is not known in many cases. Difticences in the fronds and tetraspores serve to mark the genera. Agardh and Harvey divide the Floridere into two series-the Desmiospermer, in which the spores are arranged in a definite series with regard to a placenta or common point of attachment, and Gongylospermer, where the spores are heaped together without orter. A study of the development, howerer, shows that this distinction has not the valne which it was formerly supposed to have, and certain suborders with differently arranged spores are by those who lay stress upon the development placed in proximity to others in which the spores are irregularly grouped. Although, owing to moderin researches, we know much more about the real uature of the cystocarps than was known a few rears ago, it must be admitted that the suborders of Floridec are far from satisfictory. As a matter of fact, the order is a vers natural one, and, as is tho case with most natural orders, the species and genera pass so gradually into one another that sharply marked divisions are out of the question. At the base of the order is a small number of genera whose position is doubtful, owing to our lack of information about the fructification. Then come the Porphyrea, in which we have fronds of a single layer of cells (Porphyra) aud certain cells grow out so as to form a very short 
trielongsue. Airer fertilization, the contents of the cell at the hase of the trichoursu. divisle, quadrant fishoon, and we have a mumber of spores produced at one from the original cell. In Nemalion the trichophore, or swollen hase of the trichugyne, dis ides, and the dis isions grow on laterally and firm short filaments, each cell of which beomes a spore, so that at maturity the eystorarpie fruit comsists of a dense tuft of racliating. moniliform tilaments. In the Ceramien we have fordler, or cystocapts, in which the carpegrenic cells but out and produce sereral lobes, each of which clisides into a number of very shurt filauents, which do not soparate from one another, but remain arlherent. The cells of the filanents are thameed inte speres, which form irregnlar groups, hut are still helet together hey the mase of jolly which surmunds them. In the more highly developend suborlers the spores cither ratiate in filaments from a sort of placenta which is problueed frem the carpegente crolls or else are terminal on short stalks. The pericarps are special sacks or conceptacles, inclesing the speres and deselopeed from the cells helow the proearp. or we may hase the cystocarpe berne in the interior of soliel fromes, whese external purtion may then lee satil to form a pericarp around them. It will be seen that the structure of the Floridew is more complieaterl than that of the ofluer orelers of algas, and the stulent eamot expect to obtain a cleatr

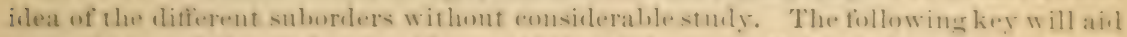
somewhat, and the realer shumlil consult the plates aplemed to this paper:

1. Spores formed in the cells of the frond itself.......... Porplyyere.

2. Spores (eystocarps) not formed directly from the cells of the frond,

lut from a special procarp ....................... ;

3. Spores without a special covering or pericarp ............

Spores with a special corering..................... 10

4. Spores naked ................................

Spores immersed in the frond ...................... 7

Spores immersed in external warts.................... 6

5. Spores free on the surface of a lobulated mass .... Spermothamnier. spores irregularly grouped in masses which are surrounded by a

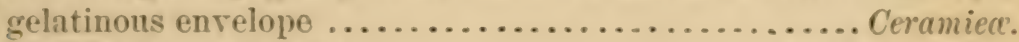

6. Fronds erect, cylindrical .................. spongiocarpece. Fromls horizontally expanded ................. stquemarieu.

7. Spores arranged in dense tufts of radiating moniliform fila-

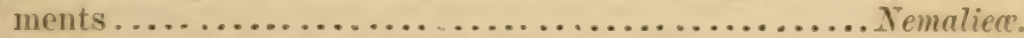

Spores on an axile placenta in swollen branches.......... Gelidiece. spores in numerous radiating tufts around a central placenta or carpogenic cell.............................. Solieriec. Spores arranged without order..................... 8

8. Sipores forming a single mass or nucleus and entirely buried in the

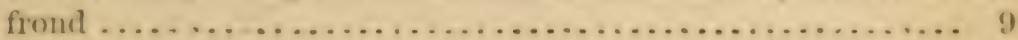

Spores in several masses, separated by the tissue of the internal part of

the frond and rising in swellings above the surfice... figgrtinere.

9. Fronds hollow and tubular................... Tumentiece.

Fronds solid ............................... Cryptonemiect.

10. Spores arranged without regular orler ................ 11 Sprores in small, scattered tufts, borne on branching filamentsIIypnere.

Spores in ratliating moniliform filaments................ 12 
Spores pyriform, on simple or branching stalks from a basal pla. centa .................................... 13

11. Wall of the conceptacle thin, composed of the divisions of an involucre united by jelly ....................... Spyridiew.

Wall of conceptacle thick, sporiferous masses arranged around a placenta .............................. Rhodymeniece.

12. Filaments arising from a single cell at the base of a thin membrana. ceous conceptacle which is sunk in the frond... Scinaia (Nemaliece). Filaments arising from a distinct basal placenta, conceptacles external ............................... Sphcerococcoidece.

13. Fronds coated with a calcareous incrustation........... Corallinece. Fronds without incrustation.................... Rhodomelece.

\section{FLORIDE A INCERT E SEDIS.}

\section{TrentepoHlia, (Ag.) Prings.}

(Named in honor of Johann Friederich Trentepohl, of Oldenburg.)

Fronds arising from a cellular base, filamentous, branching, composed of short cells placed end to end, branches ending in a hair; spores single, borne in oval cells terminating lateral branches; antheridia and tetraspores unknown.

A genus which in the present paper comprises a number of small marine species placed by some writers in Callithamnion and by others in Chantransia. In the Nereis Am. Bor., Harvey placed T. Daciesii and T. virgatula in Callithamnion. But cystocarps and antheridia are wanting, and according to Thuret and Bornet, Areschoug, and Pringsheim, the spores are undivided, although, on the other hand, Agardh and Harreystate that they are tripartite tetraspores. We have never seen any indication of division in American specimens. The genus Chantransia as limited by Thuret included not ouly marine species, but a number of fresh-water forms. Sirodot, however, in his Etude sur la Famille des Lémanéacées, Aunales des Sciences, 5th Series, Vol. XVI, has shown that at least some of the fresh-water species of Chantronsia are nothing but the initial stage of different species of Lemanece. On the other hand, Chantransia incestiens, Lenor., a minute fresh-water alga which grows on different species of Batrachospermum, and which is made the type of the genus Balbiania by Sirodot, has distinct antheridia, trichogynes, and cystocarps, and this is also the case with the marine species $C$. corymbifer a described by Bornet and Thuret in Notes Algologiqnes. The species of Chantransia, then, may be divided into two sets. In the first, including $C$. incestiens of fresh water and the marine $C$. corymbifera, we have autonomous species related to Callithamnion, and differing in the simpler procarp and cystocarp ant? in the undivided non-sexual spores. In the second set we have the numerous fresh-water Chantransia, in which there are no cystocarps, in which the species are not autonomous, but merely prothalloid stages of other species.

The question remains as to the relations of the marine Chantransia in which no cystocarps nor antheridia have been found. Julging from analogy, if they are initial stages of other plants, those plants must be members of the Nemaliea. But the habitat seems to forbid such an assumption, since the marine Chantraissice abound on Zostera, Rhodymenia, and other algæ on which certainly no species of Nemation or other related genera occur on our coast. We have thought best, in the absence of clirect information with regard to cystocarps and antheridia in the species here included, 
to retain the name Trentepuhlia which was once alopted by Harver, and at a later date alos loy Pringsheim, since it sufficiently indicates that the speries in fuestion

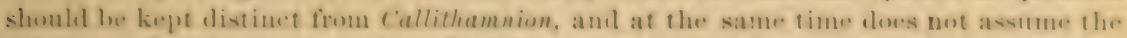
existence of eysterarps like these deseribed by Thuret and Burnet in C. congmbifira.

T. Vhisates. (Harr.). (Callithamnion virgatulum, Harv., Phyr. Brit., I'. 31:3; Ner. Am. Bor., Part II, p. 243.) Pl. X, Fig. 3.

Fronds minnte, tufterl, branches erect, straight, alternate or secund: spores sessile or on short stalks, borne either singly or in twos and threes along the branches.

Var. sectronata. (C'allithamnion lururians, Ner. Am. Bor.-C'. secundatum, Lyngb.)

Branches putent, with attenuates, naked, secund, secondary branceles.

On Ceramium. L, minuriu stems, and other algie. The variety espe. cially on Zostera.

Common in Long Island somme; Gloucester, Mass.; Peak's Islann, Maine.

A common species found in summer on difterent algat. On the filamentous species it forms small tufts, and on Zostera it fringes the margins of the leaves with a fine plush searcely more than a fuarter or half an ineh high. The synongmy of the species is very complicated, it having been confused with the next hy some writers. The variety is common on Zostera, and is usually found in American herbaria bearing the name of C. lusurians. There is little doulst that it is the C. lusurians of the Nore is $\mathrm{Am}$. bur., but whether it is the species described under that name by dgardh is doubtful.

T. D.tresit, Harv. (Conferva Dariesii, Engl. Bot., P'. 2:3:9.-Callithamnion Daviesii, Phyc. Brit., P1. 314.)

Fronds minute, tufted, branches scattered, patent, bearing in their axils fasciculated ramuli, at whose tips are borne the spores.

\section{On Rhodymenia.}

\section{Gloucester, Mass.}

The limits of the species are not well marked. The extreme form is found in $C$ : glloresens, Thuret, kept as a distinet species ly most writers, in which the branchess are few, long. and given off at wide angles, and the spores borne in dense corymh or hearls in the axils. This form has been foumel on Cystoclonium purpuraseens at ciay Hearl.

Among the genera whose relations to the Floridee must be considered doubtful are Choreowlar and I'seudoblaste, alescribed by Rr-insch in Contributiones ad Algologium it Fungologiam. Of the last-named genus a single species, of the former fire species, are attributed to the eastern const of America. The speecies of Chorecolowe consist merely of ruse-colored filaments, which are parasitie in the fronds of different Floridea, 1 pon the surface of which they produce irregularly swollen masses, composed in part of the threads of the Choreocolus and in part of the distorted tissues of the host-plant. The species of Preudubleste consist of agerregations of cells arranged in longitudinal series, which form hemispherieal masues on the snrfaee of different Floridec. In neither genus is any form of reproulnetion known, and, fur this reason, the deseriptions of Rarinselh must loe regarded as inaderpuate, since it by nu means follows that plants consisting of

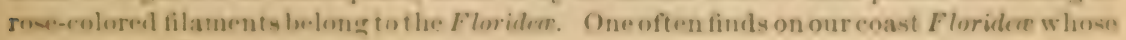




\section{Suborder PORPHYREA.}

Fronds brownish purple, composed of cells imbedded in a gelatinous net-work, arranged in filaments or in membranes formed of a single layer of cells; spores formed by the division of a mother-cell into eight cells, arranged by fours in two layers; antherozoids spherical, colorless, destitute of proper motion, formed by division of a mother-cell into 32-64 parts.

The present suborder comprises the genera Porphyra and Bangia, and perhaps also Erythrotrichia and Goniotrichum. In Porphyra the frond consists of a single layer of cells, of which those near the base send downwards root-like appendages, by means of which the fronds are attached to the substrasum. The spores are formed at the marginal portion of the frond by the division of the regetative cells, at first into two cells by a vertical partition, and the subsequent division of the two cells into four by cruciate partitions. Thus, when mature and seen from above, the eight spores seem to be arranged in two superimposed series of four. The spores escape by the dissolution of the onter part of the frond, learing behind the empty gelatinous net-work. When free they are found to consist of protoplasm without a cellulose wail, and they move about for a short time with an amœboid motion. The antherozoids are also formed by the division of the vegetative cells, but the division is carried farther than in the production of the spores, for, in addition to the vertical and cruciate partitions described in the latter case, a second vertical and cruciate division takes place, so that the original regetative cell is divided into 32-64 cèlls. Janczewski applies the name antheridium to the collective mass of antherozoids formed from a single vegetative cell. As the division takes place the antherozoids lose their color. When mature they are spherical and escape in a manner similar to that of the spores. Bornet and Janczewski state that the antherozoids are destitute of any proper motion, and we can confirm

fronds are distorted by parasites, which produce deformities like those described by Reinsch as due to species of Choreocolax. Such distortions are perhaps most frequently found on Cystoclonium purpurascens. In our present ignorance of the fructification, specific identification is out of the question, and, in this connection, it is only necessary to quote the gen eric descriptions of Reinsch, 1. c., with an enumeration of the species attributed to our coast:

CHOREOCOLAX. True vegetable parasites; fronds consisting of two portions, one of which extends through the tissue of the infected plant, the other of which swells above the surface of the infected plant, forming a convex mass, which is hemispherical or spherical, semi-ellipsoidal or irregular in outline; the cells which are contained in the infected plant either more slender than the others or of the same shape, cells of external portion equal or unequal, arranged without order in densely intricate subramose threads, terminal cells sometimes longer and more slender; fructification?; polysporangia?

C. Rabenhorsti. On Delesseria sinuosa, Anticosti ; Gloucester, Mass.

C. POLYsiphonie. On $P$. fastigiata, Atlantic shore of North America.

C. mrabilis. On Rhodomela subfusca, Atlantic sbore of North America.

C. Americanus. On Lophura Royana, \&c., Atlantic shore of North America.

C. Tumidus. On Ceramium involutum, West Gloucester, Mass.

PSEUDOBLASTE. False vegetable parasites; froud convex, more or less regular in outline, formed of similarly shaped cells, generally arranged in longitudinal series, arising from a densely appressed base (the cells without any organic connection with the cells of the infected plant); propagation?

P. Irregularis. On Lophura Royana, Atlantic coast of North America. 
on different indiriduals, or when borne on the same individual not inter. mixed, but on separate portions of the frond.

Common on stones near low-water mark.

Found in all parts of the world.

This common species abounds on rather smooth stones and pebbles, and when tho tide falls covers them with slimy films, which make walking over them difficult. The shape of the fronds is very variable, but as generally found they are much folded and laciniate. The species is used for making soups in Europe, but is not used in this country, except by the Chinese, who import it from China, not knowing that it occurs abundantly on our own coast. P. leucosticta probably occurs in New England, but has not yet certainly been observed. It is a spring species, softer and brighter colored than $P$. laciniata, and the antheridia and spores are found on the same individual, forming spots within the margin rather than a marginal zone.

BANGIA, Ljngb.

(Named in honor of Niels Hofmann Bang, of Copenhagen.)

Frouds gelatinous, simple, filamentous, cylindrical, densely tufted, composed below of a single row of cells, which, by repeated vertical division, become densely cellular abore; antheridia and spores formed by transformation of the cells of the upper part of the filaments.

A small genus, of which most of the species are marine, but some are found in fresh water. The species are not well characterized, for the differences in the length of the filaments, color, and number of cells seen in cross-section, marks upon which most writers have relied, depend to a great extent upon the age of the plant and its place of growth.

B. Fusco-purpurea, Ljngb.; Phyc. Brit., Pl. 96; Reinke, 1. c., Pls. 12, 13.

Filaments blackish purple, two to six inches long, clustered in dense masses, lubricous; antheridia and spores usually on different individuals.

On wharres and rocks between tide-marks.

Rather common along the whole coast.

Easily recognized by the fine, soft, dark-purple filaments, which cover rocks and wood work in patches of considerable size with a dense gelatinous fleece. Although found on wharves in sheltered localities, it also occurs on rocks exposed to the waves.

\section{ERYTHROTRICHIA, Aresch.}

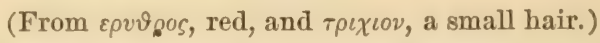

Fronds rose-colored, simple, filamentous, composed of a single row of similar cells placed end to end ; cell contents discharged in a spherical mass, which forms a spore.

A small genus, whose principal representative, $\boldsymbol{E}$. ceramicola, is by many writers placed in Bangia. As we understand the genus, it differs from Bangia in that there are $u$ antheridia or tetraspores, the reproduction being accomplished by the discharge of the cell contents in a single mass or spore. If Bangia ciliaris of the Nereis, which 
oceurs at Charleston but is not known farther north, is also to be inclucted in the preant genns, then the definition giren ahose will have to be molified so as to include plants having more than one row of colls, an extension of the genus apparently alopteal ly Thuret, but not originally alopted by Aresclumg.

E. CERAmenta, (Iyngh.) Aresch. (Bangia ceramicola, Chatuin; Plyye. Brit., P'l. 317.-E. ceramicola, Le Jolis, Liste des Ngues Marines de Cherbourg, Pl. 3, Figs. 1, 2.)

Filaments diffuse, forming a web or fringe on algite, cells about as long as broad.

On alga, especially the smaller Floridece, in tide-pools. Late summer and autumn.

Gloucester, Mass., Mrs. Maris, Mrs. Cochrane; I'eak's Island, Maine, W. G. F.; Europe.

In examining with the mieroseope the filamentous Floriden one often meets with a few filanents of this species. It is not, however, common to find it in snch alumelance on the shore as to attract the ese of the collector who is not especially in search of it. It attains its full size in the month of September.

\section{? GONIOTRICHUM, Kuitz.}

(From ywvıa, an angle, and $\tau \rho \iota \chi \iota v$, a small hair.)

Fronds filamentous, branching, composed of rose-colored, disk-shaped cells, embedded in jelly.

A genus composed of only two or three species. Kuitzing describes two species, but lis limitation of them is not now kept by algrologists. Zanardini describes and figures a (i. corrulescens, which is not red in any sense. The systematic position of the grenus is very doubtful, and were it not for the color of the cells, G. elegans would probably be flaced in the Nostochinece. The only reproduction known consists in the escape of the cells from the gelatinous sheath and a dirision into two new cells, then into four, and 80 on until a new filament is formed.

G. Elegars, Zanard. (Bangia elegans, Chaur.; Phyc. Brit., Pl. 216.)

Filaments about .02m in diameter; cells cuboidal or ovate, about $.009-10^{\mathrm{mm}}$ in diameter.

\section{On Dasya elegans.}

Cotuit I'ort, Mass., Mrs. J. T. Lusk; Europe.

$\Lambda$ small and rare plant, growing in tufts searcely a tenth of an inch high. We have only one American specimen, collected by Mrs. Lusk, of (iloucester. The locality was incorrectly given in the List of the Marine Algo of the Cnited States. Proe. Am. Acad., 1-75, the specimen not having been foumd l, Mrs. Lusk at Ciluncester, but at Cotuit, Mass.

\section{SUBoRder SQUAMARIEA.}

Frouls forming horizontally expanded crusts, usually membranaceous, occasionally somewhat incrusted with lime, composed of clusely pracked vertical filaments arising from a horizontal stratum of cells; fructification cither in external protuberances composed of parallel fila- 
ments or immersed in the frond ; antherozoids formed from the cells of the protuberances or the superficial cells of the frond ; cystocarps composed of few spores arranged end to end in a few rows, or in filaments which branch slightly; tetraspores zonate or cruciate, stalked or attached laterally to the filaments of the frond or protuberances.

A small order, more abundant in tropical seas than on our coast, comprising species which in habit resemble lichens rather than algæ. A few species, as Peyssonnelia squamaria and $P$. australis, attain a considerable size, and are distinctly foliaceous. The greater part of the species, however, form closely adherent crusts, which are sometimes more or less gelatinous and sometimes slightly calcareous. The structure of the fronds is simple. From a horizontal base, composed of a single layer or a few layers of cells, arise vertical filaments, which in some genera are densely united so as to form a parenchymatous frond, or in others are only slightly held together by a gelatinous intercellular substance. The fructification is found either in external raised spots or sunk in the frond. The antheridia are either formed directly from the cells of the filaments which constitute the protuberances or from the external cells of the fronds themselves. The tetraspores are either cruciate or zonate, and their position constitutes an important generic mark. The development of the systocarps is known in only a few species. In Peyssonnelia, according to Dr. Bornet, the procarp is formed from the cells of the filaments, which form the protuberances. The upper cell elongates and forms the trichogyne, and the fertilization consists merely in the change of the cells of the procarp into spores, thus constituting a very simple form of cystocarp, to which Zanardini has given the name of cystidie. According to Prof. Fr. Schmitz, in Cruoriopsis cruciata, Dufour, there are winding filaments like those described by Thuret and Bornet in Dudresnaya. We have but few Squamariece on our coast, and the study of the suborder cannot easily be pursued with us.

\section{PEYSSONNELIA, Decaisne.}

(Named in honor of $J$. A. Peyssonnel.)

Frouds horizontally expanded, attached by the under surface; substance parenchymatous throughout; fructification in external convex protuberances (nemathecia) composed of slender parallel filaments, on which are borne the antheridia, cystocarps, and tetraspores; antherozoids produced in all the cells of the nemathecial filaments; tetraspores cruciate, oblong, sessile or shortly stalked; cystocarps composed of few spores, placed one over another in one or two rows or in short, branching filaments.

A small genus, comprising probably not more than twelve or fifteen good species. $P$. squamaria, common in Southern Europe, is not known with us. It may be that several of the species described by Crouan in the Anuales des Sciences and the Florule du Finistère occur with us; but it must be confessed that from the description given by Crouan it would be by no means an easy matter to recognize them. Those who have an opportunity for dredging on shelly bottoms at localities like Gay Head, Block Island, Montauk, or Eastport should make a careful search for species of the present genus. 
I. Dtury, Crouan: Phye. Brit., Pl. 71; Florule du Finistere, I'. 19, Fig. 130; Proe. Am. Acall. Arts \& Sciences, 1si7, p. 239.

Fronds dark purple, thin, completely adherent to the substratum, somewhat calcareous beneatli; crstocarpic spores few in number (4-6), arranged iu one or two rows.

On shells and stones at low-water mark and in deep water.

Eastport, Maine: Magnolia, Mass.; Europe; California.

As yet only found in a sterile condition, apparently not common. The speries might possibly be mistaken for Petrocelis cruenta at tirst sight. It is, howerer, more decidedly redulish and thicker. Ender the mierescope the strueture of the frond is seren to be parenelycuatons thronghont, while in I'etrocelis the rertical filaments are mearly free from one anether. P. imbricata, Kiitz., Tah. Phyce., Pl. 90, from Newfonndlauh is a doubthul speries, which is not likely to he recognized ly future hotanists.

PETROCELIS, J. Ag.

(From $\pi \varepsilon \tau \rho \circ$, a stone, and $\kappa \eta \lambda \iota$, a stain.)

Fronds gelatino-coriaceous, horizontally expanded, indefinite in outline, alhering closely to the sulstratum, rertical filaments united helow, but above rather loosely held together by a gelatinous substance; antheridia and esstocarps unknown; tetraspores spherical, eruciate, formed directly from some of the cells of the vertical filaments.

A genus represented by a single species, which is widely diffused in the North Atlantie. At once recognized hy the peculiar position of the cruciate tetraspores, which are in the continuity of the vertical filaments. There is usually only a single tetraspore in each filament, but Ruprecht, in Phycologia Ochotensis, figures a form in which several contiguons cells are transformed into tetraspores.

P. creenta, J. Ag. (Cruoria pellita, Harv., in Phyc. Brit., Pl. 117, non C. pellita, Lyngb.) Pl. 14, fig. 1.

Corering rocks and stones near low-water mark with a dark purple, velrety stain.

Common from Nahant northward; Europe.

The present species often accompanies Mildenbrandtin roxea, from which it is distinguished at sight ty its darker color and velvety gloss when moist. It is also deciledly thicker and more easily scraped from the rocks. The species is not yet known south of Cape Coul, lut may be expected. The fronds of the present species are infisted by a green unicellular parasite, which is frequently seen in the shape of ovoid sacks, drawn out at the lower end into a slender stalk amonest the vertical filaments. It is, in all probability, the parasite mentinnel by Colno, in Celuer einige Algen von H. l.guland, as oceurring in Crumia pellita, to which, as far as we know, no name has as yet been given.

IILDENBRANDTIA, Nardo.

(Named in honor of Prof. Franz Edler Hildenbrandl, of Vienna.)

Fronds crustaceous, without calcareous deposit, forming thin, redilish, horizontal expansions of iudefinite extent, composed of cuboidal cells arranged in rertical lines and arising from a horizontal basal layer; 
tetraspores lining the walls of immersed conceptacles, zonate, cruciate, or irregularly placed; cystocarps unknown.

A small genus, comprising half a dozen species, which form thin crusts on rocks and stones both in salt and fresh water. The systematic position of the genus is doubtful, and must remain so until the cystocarps are known. Since the tetraspores are borne in special conceptacles, the genus has been placed by some writers with the Corallinece, although the species are not strictly calcareous. By others it is placed with the Squamariex. Antheridia are only known in $H$. rivularis, where they are said by Borzi to be long cylindrical cells formed from the superficial cells of the thallus, each cell containing a number of spherical antherozoids arranged one above another.

H. rosea, Kütz. (H. rubra, Harv., Phyc. Brit., Pl. 250; Farlow, in Report of U. S. Fish Comm. for 1871.)

Fronds thin, closely adherent to the substratum, cells of nearly the same size in all parts of the frond; conceptacles numerous, completely immersed, spherical; tetraspores either zonate or irregularly divided, lining the walls of the conceptacles and mixed with filiform, slender paraphyses.

On stones and rocks near low-water mark.

Everywhere common.

One of our commonest species, which forms continuous thin crusts, often of considerable extent, tinging the rocks with a pinkish or somewhat brownish color; not easily mistaken for any other alga on our coast, except possibly young forms of Petrocelis, which is, however, thicker, more velvety in appearance, and darker in color.

\section{Suborder NEMALIE E.}

\section{(Helminthocladiece, Agardh \& Harvey.)}

Fronds more or less gelatinous or occasionally coated with a calcareous deposit, filamentous, branching, formed of an axial portion composed of elongated longitudinal filaments, which give off short, corrmbose, horizontal branches, which constitute the cortical portion; antheridia in tufts on the superficial cells; cystocarps immersed in the frond, borne on the peripheral filaments, composed of densely packed chains of spores radiating from a central cell, either without any proper envelope, or with a filamentous involucre or surrounded by a proper membranous pericarp; tetraspores?

A comparatively small suborder, comprising species whose fronds, except in color, resemble the fronds of the Chordariea in the Phrosporea, since they consist of an axis composed of longitudinal filaments and a cortex of short, much-branched horizontal filaments. All our species are soft and somewhat gelatinous, but the species of Liagora, which abound in the tropies and are found in Southern Europe and in this country in Florida and California, have a more or less distinct coating of carbonate of lime. The procarps and cystocarps in this suborder are very simple. There are a few species belonging to the genus Batrachospermum which occur in fresh water. In that genus the formation of the cystocarps is very simple. The trichogyne and trichopore are represented by a single large cell, constircted near the base. After fertilization the chains of spores are formed directly from the part below the constriction. In 
Venclion the procarp consists of a short branch composed of a few cells, the uppur of wheh enlarges and hears a hair-like trichergme. The fruit in Kemaliom has no special cosering, but in Melminthora and Ilelmintheledia the lower cells of the procarp produee whorls of tilaments which firm an insoluere around the spores, and in scinaid they produce a uesu!ranous sack which opensat the apex, so that when ripe the fruit consists of a coacentacle opesing ontwarils, at whose hase is horne a tuft of sporrs arranged in filaments. With regard to the tetraspores in the present suborder, a difdiemee of opinion exists. Contrary to what is fomml in other Flonder, the eysor-

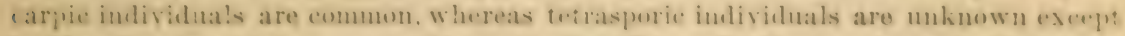
in Nomalion, in which genns, on the anthority of Agarih, they are borne in the snperficial cells aud aro tripartite.

NEMALION, Duby.

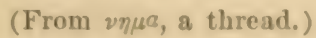

Frouds gelatinous, cylindrical, solid, repeatedly dichotomous, cortical filaments corymbose, giving off descending branches, which unite with the axial filaments; antheridia in tufts on the superficial cells; procarps borne at the base of the corrmbose branches, consisting of few cells; (ystocarps immersed, without special covering, sporiferous filaments radiating from the trichophore; "tetraspores tripartite in the superficial" cells. (Agardh.)

A small genus, comprising seven or eight species, only one of which, I. multifidum, is widely diffused.

X. multifidror, Ag., P'ișc. Brit., Pl. 36. (Mesogloia multifida, Ağ., Syst.) Pl. 12, Fig. 1.

Fromls brownish purple, lubricous, two to eight inches long, cylindrical, several times dichotomous, axils obtuse.

On exposed rocks at low-water mark. Summer.

From Watch Hill, R. I., northward; Europe.

Sut uncommon on rocksexposed to the action of the waves. Commonly fouml with rysturarps. bint no tetraspores have been seen on American specimens. In the Nereis the species is said to have been collected at Bangor, Maine, by Mr. Inoper. This must he an error, however, since Bangor is on the Penolsset River, above the limit of sait water. Specimens of the present species are so gelatinous as to dry with diffiwity. They shonld be exposed in the air for two or three hours before pressing.

\section{SCINAIA, Bivona.}

(In honor of Domenico Scina, of Palermo.)

Fronds subgelatinous, dichotomous, cylindrical or compressenl, axis small, composed of slemer colorless filaments, horizontal filaments ending in short corymlss of small, round, colored cells, the centers of all the corymbs bearing large, colorless, cylindrical cells, which by their juxtaposition form an epidermis over the whole frond; antheridia in small tufts on the superficial cells; cystocarps borne just below the cortieal layer, consisting of membranous sacks opening externally, with a tuft of spore-bearing filaments attarhed to the base; tetraspores unknown. 
A small genus, containing at the most only four or five species, of which $S$. furcellata is widely distributed. The genus is unmistakable on microscopic examination by the slender axis and large colorless cylindrical cells which cover the surface of the fronds, and by the peculiar cystocarps which are visible to the naked eye as dark red grains just under the surface. The species should be studied from living or alcoholic specimens, since, owing to the delicate substance, pressed specimens are badly distorted.

S. Furcellata, Birona. (Ginannia furcellata, Mont.; Phyc. Brit., P1. 69._S. furcellata, Notes Algologiques, P1. 6.)

Fronds solitary or clustered, cylindrical, rising from a disk-like base, sereral times dichotomous, divisions regular, apices obtuse.

On stones and shells in five to ten fathoms.

Newport, R. I., Bailey; Gay Head, Mass., W. G. F.

A rare species with us, but widely distributed throughout the world, being found in most warm seas. In size and regularity of its dichotomous branching it resembles Polyides rotundus, but is much more delicate in substance and brighter colored. With us it is only known at a considerable depth and in rather cold waters, but in the Mediterranean it is frerquent in warm shallow waters. It is not uncommon on shells of Mytilus near the Devil's Bridge, Vineyard Sound, Mass., and is found washed ashore in the neighboring beach of Gay Head. The Californian form of what is supposed to be the same species is much more robust, and the var. undulaa, which Montagne considered a distinctspecies, is somewhat compresed and constricted at intervals. When pressed the specimens are quite flat and the axis is plainly seen, giving the appearance of a membranous frond with a midrib.

\section{SUBORDER SPERMIOTHAMNIE E.}

Fronds filamentous, monosiphonous, branching; antheridia tufted; cystocarps involucrate, spores borne free on the surface of a lobulated mass produced by the carpogenic cells.

In this suborder we would place Spermothamnion and Bornetia, separated from Callithamnion and Griffithsia, respectively, in consequence of the spores being borne free.

\section{SPERMOTHAMNION, Aresch.}

(From $\sigma \pi \varepsilon \rho \mu a$, a seed, and $\vartheta a \mu v \iota v$, a small bush.)

Fronds tufted, composed of procumbent monosiphonous filaments attached to the substratum by disk-shaped cells and rertical branching filaments; antheridia sessile on the inner side of the branches, composed of oval or cylindrical masses of small cells; cystocarps terminal on the branches, surrounded by an involucre of short incurved branchlets, spores free from one another and not surrounded by a gelatinous enrelope; tetraspores tripartite, single or aggregated, borne on the inner side of the branchlets.

A small genus, comprising, as far as known, less than half a dozen species, separated from Callithamnion because the spores at maturity are borne free on the surface of a lobulated mass which arises from the development of the carpogenic cells, and not, as 


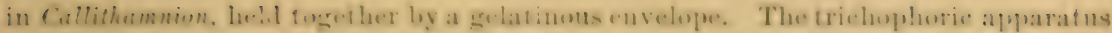

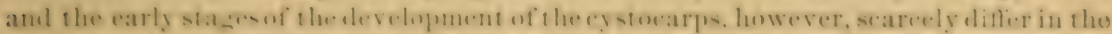

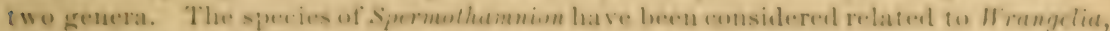

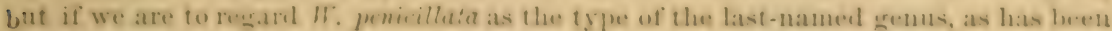

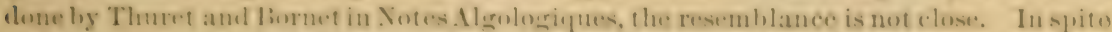
of the fact that the thuit of Sprermothamnion is not a true favella, there is little dombt that the genus should he placed in the Coramied, near Callithamnion. The deselopment of the genus has heen rery thoroughly stulied and has fermed the suleject of sereral

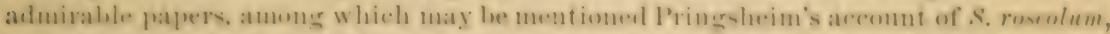
in his Beitrige zur Morphologie der Mewes-Algen; N.Preli on S. Turneri and hermupheroditum, in lieitrïge zur Morphologie und sistematik der Ceramiacear ; asul Thuret and Bornet on Spermothamnion flabellatum, in Notes Algologiques.

s. Torseni, Aresch. (Callithamnion Turneri, Ag.; I'lje. Brit., I'l. 179: Ver. Am. Bor, l’art III, 1). 241.-s. roscolum, Pringsh., 1. e. ?Herpothamnion Turneri, Nag.)

Fromels forming densely matted tufts, procumbent filaments branch. inc. attacher by disk-like cells, rertical filaments one to three inches high, simple or slightly branching, naked below, pinnate above with opposite or sometimes alternate spreading pimnate branches, ultimate branches long and slender, often ending in a hair; antheridia ovate or eylindrical, sessile on the upper side of the branches; eystocarps involucrate, terminal on the branches; tetraspores tripartite, borne on the "pper sille of the ramuli, either solitary and pedicellate or clustered and sessile on short fastigiate branches.

Var. variabile, Harv.

Branches and branchlets alternate or secund.

In very dense tufts on algae at low-water mark or in deep water.

Common in Long Island Sound; var. variabile, Boston, Di. Durlice.

A speeries which is often fonnd washed ashore in dense ghlobose tufts from our sonthern limit to Nantucket. At the latter locality it is often found in very large yuantities wa-heal from deep water by the surf on Siaseonsett Beach. The filaments are delieate and of a pleasant lake color. North of Cape Cod the speceies is hardly known with wrtainty. Specimens collecterl at Noank, Conn., have both tetraspores and young egstocarps on the same individual, but we have never seen anthericlia on American sperimens. Our plant suems to be the same as that figured by P'ringsheim under the name

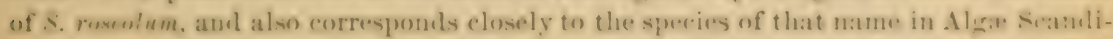

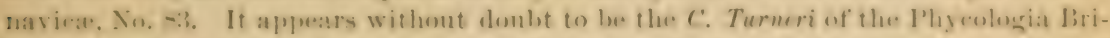
tauniea and the Xereis, lut we are unable to say whether it is the true C. remelum of Agarilh.

\section{Suborder CERAMIEA.}

Fronds filamentous or compressed, either monosiphonous or with a more or less corticated monosiphonous axis ; antheridia in sessile tufts or patches or in a series of whorls; (eystocarps (favellie) composed of spores arranged without order and surrounded by a gelatinous envelope, naked or involucrate. 
A large order of filamentous algæ, many of which are monosiphonous throughout, while others are corticated either throughout or partially. The position of the antheridia and tetraspores varies in the different species. The cystocarp is a favella, which is either naked or surrounded by an involucre arising from the cells below the carpogenic cells. In cases where the frond consists of an axis with dense whorls of branches the favellie may be partly concealed but not really immersed in the frond. The order is tolerably distinct. The fronds resemble closely those of the IFrangeliea, and on the other band the order passes gradually into the Cryptonemiece by the genera Gloiosi. phonia, Calosiphonia, and Temastoma, in which the fruit is properly a favella, but is immersed in the comparatively dense outer portion of the frond instead of being free as in the Ceramiea. In fact, it is difficult to say in which suborder Gloiosiphonia should be placed.

1. Tetraspores exterial, occupying the place of a branchlet or ultimate

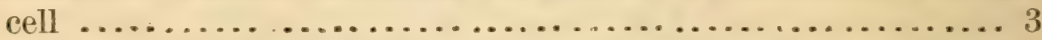

2. Tetraspores wholly or partly immersed, formed from the corticating cells.................................... 4

3. Fronds filamentous, monosiphonous, or with a false cortex composed of descending filaments, favellie naked or with only a rudimentary involucre ............................ Callithaminon.

Fronds filamentous, monosiphonous, dichotomous, favellæ involucrate ............................................

Fronds filamentous, branches densely whorled on the axis, farellæ

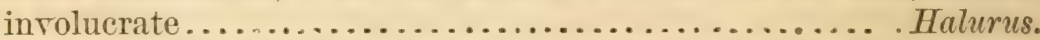

Fronds compressed, corticated, decompound-pinnate, favellæ involu-

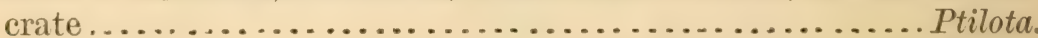

4. Fronds filamentous, monosiphonous, cortications at the nodes and extending over the internodes................... Ceramium.

\section{CALLITHAMNION, Lyngb.}

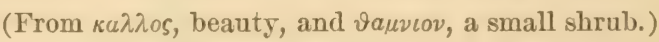

Fronds filamentous, branching, filaments either monosiphonous throughout or becoming corticated by the growth of descending, rhizoidal filaments; antheridia forming hemispherical or ellipsoidal tufts on the branches; cystocarps composed of irregular masses of roundish spores corered by a gelatinous envelope (farellæ); tetraspores tripartite, cruciate, or polysporic; seirospores present in some species.

A large and beautiful genus, of which nearly 150 species have been described. Although the grems has been divided into a number of smaller genera, the number of species still retained in Callithamnion proper is large. Nageli, in his paper on the Morphology of the Ceramiacese, divides Callithamnion into a number of genera and subgenera, but we have thonglat best to retain the genus in an extencled sense, regarding Niegeli's division as sulurenera. Spermothamnion, included by Nregeli in Herpothamnium, has been separated because the cystocarpic fruit is not strictly a favella as in Callithamnion proper. Seirospora is still retained, although it is possible that it could safely bo separated as a distinct genus. The frond in Callithamnion is composed, in the beginning, of rows of cells arranged in branching filaments. In the subgenus Rhodochorton, whose relatire position is doubtful because the cystocarps have not yet been observed, thero are procumbent filaments, from which arise vertical branching filaments. In the other 


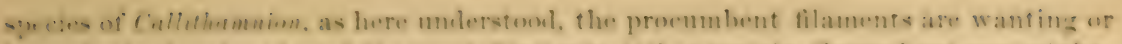

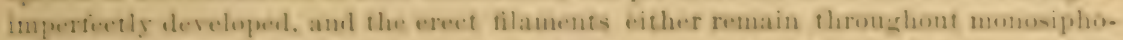
meas, that is compused of single rows of cells, or become corticated ly the growle of dewending filaments, which proesed either from the base of the branches or frosu the cells of the main filaments. The false cortication formed by the interlaring of

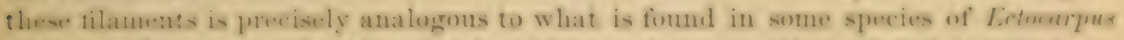
amb related senera. The filaments in Callithamniom are either all imleterminate in growth, or clos, as in the sul,genus Antithumnion, they are of two kinds; the main filament b lug imbetinite and the branches definite, so that we have indefinitely elongating stem- clothed with short, definte loranches, or, to use the expresion of Xagreli, with leas...s. The antherilia are generally in the form of short tufts of hyaline cells, sitnatol on the nuper lorambers. In the present genus it is not rare to fiml species in whirh antheridia, eystomarps, and tetraspores are borme on the same imdiviluals, a unim rarely to be seen in the Floridee. The eystocarps are often binate, which is easily understoor if one considers the structure of the procarp, which is formed as follows: Oae of the colls of the young hranches enlarges and is then divided hy partitions furallel to the length of the branch into a central or axial cell aul a number of periplueral celi- generally four. One of the peripheral cells is then divided into an upper and oue or more lower cells by a transverse partition, and the npper cell then fones its eulor and grows upwards into a very long trichugrne. The antherozoids mite with the tip of the trichoggne, and the fertilizing intluence is propagated through the trichegyne and the cells at its hase to the two lateral peripheral erlls, which then enlarge and divide on opposite sides of the axis and form eventually a bipartite farella. The. twra-jores are either tripartite or cruciate. In the subenus seimomom there is a form of non-sexnal spore known as seirospores, in which at the extremity of the lorameles are formed tufts compused of chains of oval borlies, each one of which is capable of germinating.

As is apt to he the case in a large genns, the species of Cullithumnion are not well definel. Certain gremps of speecies are slistinct, lut writers are nut agreed as to the limbis of the species in each group. By some a great many species are allowed which

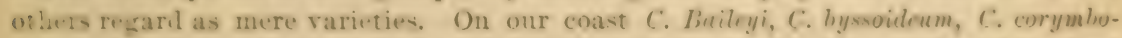
cas aml perhaps ot hers might he indefinitely split up, hut we have prefierred to adopt the approsite view. Within certain limits collectors may be experted to make out our species of Cullithamnion, but it must often happen that forms are found which eannot with eertainty be referred to any of the described species. That such forms are, as a rule, new species cannot be accepted, but lotanists having large sets of specins of the puracint genus soon become very liberal in the interpretation of sperifie limitations.

\section{Subgexes RHODOCHORTON, Ning.}

Fronds composed of procumbent filaments, from which arise rertical monopodial filaments; cortications wanting; tetraspores cruluate.

\section{IRotnin, Lyngb. (Rhodochorton Rothii, Nieg.-Thamnidium Rishii,} Thuret, in Le Jolis's Liste des Algues Marines de Cherbunrg. Pl. i, Figs. 1-2.-C. Rothii, Phyc. Brit., Pl. 120 b.)

Fronds forming indefinite patches half an inch high, vertical filaments shenler, naked below, bearing a few erect, appresieal limalues abore. which betome at the time of fmetitication congested and corymbose, bearing at their tips cruciate tetraspures; antherilia and eystogarps unknown.

Forming alense velvety pateles on rocks between timle markis. 


\section{Common from New York northward; California ; Europe.}

A common species, especialls frequenting the under surface of rocks and stones near low-water mark. It has not jet been found with us in fruit, but Californian specimens bear tetraspores. In Europe the iime of fructification is the spring, and the species should be examined at that season on our own coast. Harvey states that the tetraspores are tripartite, but other writers-as Thuret, Agardh, and Nægeli-agree in asserting that they are cruciate. In Californian specimens the formation of the tetraspores is somewhat irregular, and although in most cases the cruciate division is plain enough, in others it seems to be rather tripartite.

\section{Subgexes ANTITHAMNION, Thuret.}

Branches opposite or whorled, without cortication; tetraspores cruciate.

C. CRUCiatur, Ag. (Antithamnion cruciatum, Nrg.-C. cruciatum, Phyc. Brit., Pl. 16t.)

Fronds tufted, one or two inches high, main branches sparingly and irregularly branched, secondary branches short, borne in twos or fours just below the modes, always regularly opposite, and when in twos the succeeding pairs at right angles to one another, below subdistant, at the apex densely approximate and corymbose, pinnate with erect, alternate, distichous branchlets; tetraspores cruciate, sessile, or shortly stalked at the base of the secondary branches.

On wharres at low-water mark and on algæ in shallow rater.

Red Hook, N. Y., Harrey; Orient, L. I. ; Noank, Conn.; Wood's Holl and sereral localities in Vineyard Sound, W. G. F.; Europe.

Not common, but, on the other hand, not rare south of Cape Cod. It is a small and not very beautiful species when growing, but ratber pretty when pressed. It is clistinguished from the following species by its small size and sparingly branched main branches and by its tetrastichous, not distichous, secondary branches, which are densely approximate at the tips, so that in dried specimens the plant is rather pale except at the tips. Cystocarps and antheridia have never been found on our coast. Crouan states that the cystocarps, which are rare, are large, rounded, and slightly lobed. The branches of the present species, as well on our own shore as in Europe, are beset with small crsts with oily contents-the Chytridium plumula of Cohn. The same parasite is also found on the branches of $C$. Pylaiscri aud C. plumula on the New England coast.

C. floccosur, Ag. (C. floccosum, Phyc. Brit., Pl. 81.-Pterothamnion floccosum, Nag.)

Fronds three to six inches long, capillary, main branches irregularly and sparingly branched below, abore with numerous alternate branches, which give the tips of the frond a rhombic-oroid outline, clothed throughout with short, simple, opposite, distichous, subulate, secondary branches; tetraspores cruciate, sessile or on short stalks on the lower part of the secondary branches. 


\section{On submerged algæ.}

Lastport, Maine, W. G. F.; Portland, Maine, C. B. Fuller ; Cloncester, Matss., Mrs. Bray and Mrs. Daris; South Boston, Dr. Durlice; Northern Europe.

A beautiful and easily distinguished species, found only in the coleler watere of the Atlantic, a rariety ocenrring as far sonth as fouth liarlara, on the coast of California. It is apparently not uncommon in spring from boston northward, sometimes occurring in company with $C$. I'ylaiseri. It is rare, howerer, on the northern coast of Scotland. It is easily distinguished from its allies in this latitule hy the simple, subulate, secemelary hranches with which the main laranches are chothes throughont.

C. Pruanser, Mont. (Wrangelin I'yluiseri, Ag. Sp.-C. Pylaiseri, Xer. Am. Bor., Part II, Pl. 35 b.-Pterothumnion Pylaiscti, Nieg.)

Fronds three to six inches lorg, main branches alternately decompound, secondary branches short, rather stout, opposite, distichous, once or twice pinnate with short subulate ramuli; tetraspores cruciate, sessile on the ramuli f farellae binate on the upper branches.

On wharves and algæ below low-water mark.

Orient, L. I., Miss Booth; Wood's IIoll, Mass.; and common from Nahant northward.

A common species of the Atlantic coast from Boston northward, hut much lews ahmolant southwarl. It is fouml early in the spring on wharves and washed a-lore with other algat, but in the smmmer it is only seen in a dwarfed and battered condition. It is sometimes found in company with $C$. Americunum, and it is ly no means leyond a denulut that the two species are really distinct. In C. I'ylaisar the filat ments are more rohust, and the cells themselves shorter and broader than in $C$ : Americanum, the main branches are less decompound and spreading, and the apical hranches are more erect and compact. It is, however, in the secontary branches that the difterence is best seen. In $C$. I'yluisui they are short and thick, and the ultimate divisions are hroadly subulate. In C: Americanum they are long, slender, ancl nexuous. Those who have only seen the typieal forms of the two species woulh scarcely believe that they were not very distinct species. The collector, howerer, specially on our northern coast, often finds transitions between the two. At the time the Nereis was written the eystocarpie fruit was unknown, and the species seement to Agarelh to leelong rather to the genus Wrangelia. The fruit, which is not nneommon in the spring, is distinctly the same as in Callithamnion, and is a true favella. The antheridia diftir from those of $C$. corymbosum and its allies. Insteal of forming sessile, hemisplerical tufts on the internodes of the branches, as in the last-named species, the antheridia of $C$. Pylaixai are in the form of rather loosely branching tufts inserted at the nodes of the secondary lianches, and oceupes the position of the ultimate hranches, reminding one somew hat of the anthericlia of C. graniferum, Menegh., figureel by Zanardini in Phycologia Adriatiea, Il. 11, or the figure of $C$. pulyspernum in Plyyeologia Britanniea. As far as our olservations go, the autheridia and cystemarps of the present speecies are on diffirent individuals. The color, when dried, is usually somew hat hrownish, and decidedly less ruse-colored than in C. Americunum.

C. Americancm, Harv, Nereis Am. Bor., Part II, p. 235, Pl. $36 a$. (Plerothamnion Americanum, Nag.)

Fronds three to six inches long, capillary, main branches alternately many times branched, nltimate divisious plunose, secondary branches 
rather long and slender, opposite, in tros or occasionally in fours, generally distichous, widely spreading, once or twice pinnate, ultimate divisions opposite or secund, long and slender; tetraspores cruciate, sessile on the upper side of the secondary branches; farellæ binate.

Exs._Alg. Am. Bor., Farlow, Anderson \& Eaton, No. 89.

On wharres and algæ below low-water mark. Spring.

From New Jersey northward.

A common and very beautiful species, more abundant in Long Island Sound than farther northward. It varies considerably in the compactness of the branching and the tenuity of the cells. The species with which it is likely to be confounded is C. Pylaisci, as already indicated. The long and slender secondary branches are less regularly placed than in some other species of the subgenus, and they are not always distichous nor opposite, although that is generally the case. We have also seen a specimen on which both tetraspores and cystocarps were found together.

C. Plumula, Lyngb., Phyc. Brit., Pl. 242.

Fronds two to four inches long, main branches alternately decompound, secondary branches opposite or in fours, distichous, short, recurred, pectinate on the upper side with 1-3 pinnated branchlets; tetraspores cruciate, shortly pedicellate on the branches.

On wharves and on shells in deep water.

Long Branch, N. J., Harvey; Orient, L. I., Miss Booth; on steamboat Tharf, Nemport, R. I.; dredged in 8-10 fathoms, Gay Head, W. G. F. ; off Block Island, Professor Eaton.

A rare species on the American coast, and known in but few localities. It is found occasionally on wharves just below low-water mark, but more frequently on shells in from fire to ten fathoms. It is tolerably abundant off the Devil's Bridge, near Gay Head, where it is found in company with Lomentaria rosea. It is one of the most easily recognized species of the genus found on our coast. The branches are beautifully srmmetrical and distichous, two opposite branches being given off from each cell, or occasionally there are four in a whorl, two being smaller than the others. The branches are recurved and furnished on the upper side only with 1-3 pinmate branchlets.

\section{Subgexus PLEONOSPORIUM, Næg.}

Fronds erect, pinnate, cortication wanting; antheridia eylindrical on the upper branches; farellæ terminal, involucrate; tetraspores polj. sporic.

C. Borreri, Ag., Pliyc. Brit., Pl. 159.

Fronds diœcious, densely tufted, monosiphonous, with a fer rhizoidal filaments at the base, filaments one to four inches long, capillary, main branches sereral times pinnate, branches beset in lower part with usually simple, elongated branchlets, distichously pinnate above, ultimate ramifications broadly orate or triangular in outline, branchlets naked below; antheridia cylindrical; tetraspores sessile on the upper 
branchlets, numerons, tripartite or polysporie; favelle terminal on lateral bramehes, usually composed of several distinct lobes, furnisherl with an involuere by the growth of a few incurven accessory branches below.

\section{On wharves and Fuci.}

New York, Harrey; New Haven, Profissor Euton; Newport; New Bedford; Wood's Holl; Europe.

Apparenty rather a common species, especially on wharves and Fuci at low-water mark. The species is easily recugnized, when in fruit, hy the polysporic tetraspores and hy the favellar, which are terminal, not lateral, as in the rest of our species, and have a sort of involucre formed by the growth of accessory ramuli from the cells just below the favellip. When sterile the epeecies may be reeognizenl loy the regnlar, hroadly pinnate tips, at the end of nearly naked branches. We have found both polyspores and favella on American specimens ; and in spite of the fact that our plants are always more slender than European forms of the species, there can be almost no doubt that we have the true $C$. Borreri. Whether all the sterile forms referred ly Aueriean botanists to C. Burreri are correctly determined is doubtful. Some perhaps belong rather to C. roseum. The present species is placed ly Bornet in the gremus Corynoxpora, lecause of the terminal and iuvoleurate favelle and polysporic tetraspores. As writers differ about the limits of Corynospora, we have kept the species in Callithamnien, although in some respects it differs from the rest of the genus, and the young stages of the eystocarps remind one strongly of Spermothamnion. The fruit is, however, a true favella. The number of spores in the polyspores in American specimens rarely exceels 8 or 10 , whereas Niegeli puts the number as high as $20-23$ in European specimens. As usually found in early summer, the species is small and delieate, but later it hecomes coarse. Specimens collected as late as possible in the autumn are to be desired, and the number of spores in a polyspore should be ascertained more definituly. In Contributiones ad Algologiam et Fungologiam, p. 44, Pl. 23, Fig. 1, Reinsch describes and figures a Callithamnion Labrudorense, which is said to have polyspores-whether a polysporic condition of $C$. floccosum or not can lardly be determined from the description.

\section{SUBGEXU'S ELCALLITHAMNION.}

Fronds erect, cortications generally present; antheridia in tufts, either on the nodes or internodes of the branchlets; tetraspores tripartite; farellæ nsually binate, lateral.

\section{Sect. I. Pennat .}

Grouth monopodial, finds distichously pinnate, pinne alternate, cortications rudimentary or wanting.

C. Roseum, (lioth), Harrey. (C. roseum, I'hye. Brit., Pl. 2:30.-Phlebothamnion roseum, Kütz.)

Fronds capillary, two to four inches high, filaments diffusely branched below, main branches slightly corticated, secondary branches long, flexuous, distichously pinnate, pinnx crowded at the ends of the branches, long, sprearling or slightly incurved; antheridia in tufts on the nodes of the branchlets; tetraspores tripartite, sessile on the branchlets; farellæ binate on the upper branches. 


\section{New York Harbor, Mr. A. R. Young; Wood's Holl, Mass.}

There must remain some doubt as to the correct determination of American specimens of the present species in the absence of fruit of any kind. Sterile specimens of C. roseum are likely to be mistaken for varieties of $C$. polyspermum or $C$. Borreri. In C. polyspermum the pinu:e are short and subequal, so that the outline of the tips of the branches is linear or oblong, while in $C$. roseum the pinna, which are crowded at the ends of the branches are long, gradually diminishing in size towards the apex, so that the plumose tips are prramidal or broadly orate in outline. The filaments of $C$. roseum are finer and more nearly rose-colored than those of $C$. Borreri, and the pinnæ are less regularly distichous. Furthermore, there are no polyspores in C. roseum, and the farellie are not terminal and subinvolucrate as in C. Borreri. All three of the species above named are distinct from the species of the following group in their distichously jinnate ramification, and all three are reddish, inclining to a brownish color. They collapse when removed from the water, but are hardly gelatinous, although all adhere well to paper in drying.

C. polysperiugr, Ag. (C. polyspermum, Phyc. Brit., Pl. 231.-Phlebothamnion polyspermum, Kïtz.)

Fronds capillary, cortications wanting, two to three inches high, main branches irregularly dirided, with few secondary branches below, distichously pinnate above, branches linear or oblong in outline, simply pinnate, pinnæ alternate, short, subequal, incurved, upper pinnæ sometimes pinnulate; tetraspores tripartite, sessile on the upper side of branchlets; favellæ binate near the ends of the branches.

Hell Gate, N. Y.; Jackson Ferry, Harvey; Europe.

The only localities for this species within our limits are the two given by Harrey. We have seen Californian specimens collected by Mr. Cleveland near San Diego, but have never found the plant on the New England coast. The species is related to C. roseum and is distinguished from it by the short, subequal ultimate branches.

\section{Sect. II. Fruticosa.}

Growth sympodial, main axis and branches densely corticated: branchlets pectinate or pinnate, ultimate divisions alternate or secund.

C. tetragonum, Ag. (C. tetragonum, Phyc. Brit., Pl. 136.-C. brachiatum, Harv., l. c., Pl. 13.-Dorythamnion tetragonum, Næg.)

Fronds monøecious, two to six inches high, coarse and spongy, shrublike, pyramidal in outline, color dark purple, main filaments densely corticated, smaller filaments monosiphonous; main axis percurrent, attached by a disk, pinnate with long, undirided, alternate branches, which are once or twice pinnate, the ultimate divisions beset on all sides with short, stout, incurved, acutely pointed, fasciculate branchlets; cells stout, not much longer than broad; antheridia in tufts on the upper internodes; tetraspores tripartite, sessile on the upper branchlets; favellæ binate.

Common on stones and alga below low-water mark.

Long Island Sound; Europe. 
Our most robust and coarest speries, not nneoramon in Long Islanel Soumd, luut unt set recorded north of Cape Coul. The eolor is dark, ant in the water almost hlack, and the sulstance is rather spongry, the plant not enllapring when removed from the water, as do most of the New Englamel species of the genus.

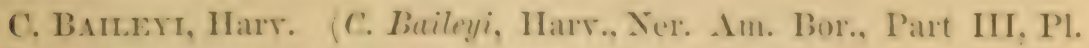
3.j b.-IDorythumnion Buileyi, Xisc.) Pl. XI, Figs. 1-2.

Fronds moncerious, two to four inches high, sertaceous, shrub-like, pyramidal in outline, color purplish red, main filaments densely corticated, the rest monosiphonous; main axis percurrent, attached by a disk, pinnate with long, undivided, alternate branches, which are once or twice pinnate, the ultimate dirisions beset on all sirles with rather slender, flexuous, recurred or incurred, fasciculate branches; cells several times longer than broad ; tetraspores tripartite, sessile on the upper branchlets: antheridia in tufts on the upror internoles: farellat binate.

Var. LAxA.

Cortications less marked than in the type, branchlets long aud slen. der, divisions widely spreading below, fastigiate at the apex.

On Zostera, stones, sponges, and algie below low-water mark.

Common from New Jersey to Cape Cod; Boston Bay, Harrey ; Port. land, C. B. Fuller.

As is suggested by Harrey in the Nereis Am. Bor., the present species is not only very variable in habit, but it is also dithicult to distinguish some of the forms from $C$. tetragonum. We are inclined to believe that it would be better to consider the present speecies as a delicate form of $C$. tetragonum, in which the cells are longer and more slender, the branchlets less dense and robust, the color less inclined to blackish, and the substance more delicate. If we are to unite Rhodomela subfusca, R. gracilis, and $\boldsymbol{R}$. Liochei in one species, as has been done by Agardh, with good reason as it seems, it would be equally correct to unite $C$. Baileyi and C.telragonum, since the difference in habit might result from variations of habitat and season. With us, the form here refirred to the typical $C$. Baileyi is more common than $C$. tetragonum, and is found on wharres, on Zustera, shells, aud stones in rather warm waters and sheltered places, while C. tetragonum frequents places where there is a current of water, or grows on alga in somewhat exposed pools. The var, laxa has a diffuse ramification and the cortications are not prominent, and we at one time supposed that it might be the $C$. Dhetzir of the Nereis, as far as we could recollect the specimens of that species in the Harveyan Herbarium at Dnlulin. In such cases, however, it is not safe to trust to one's memory, and in the present article we are unwilling to express an opinion about C Dietzio.

Sect. III. BYssoID A.

Branching monopodial or dichotomons. corticutions present at the buse, ultimate branches decompound, very delicate, usunlly ending in a hyuline hair.

C. Brssonder, Aru. (C. byssoideum, Pliye. Brit., Pl. 2012.-Phlebothamnion byssoides. Kiitz. - I'acilothamnion byssoirleum. Xiters.) 
Fronds globosely tufted, one to three inches high, filaments very delicate, slightly corticated at base, main branches many times divided, secondary branches long and flexuous, pinnate with numerous pinnately compound branchlets; antheridia sessile in tufts at the nodes of the branchlets; tetraspores tripartite, sessile on the upper side of branchlets ; favellæ binate on the upper branches.

Var. unilaterale, Harv.

Fronds small and very delicate, branches and branchlets often secund.

Var. Fastigiatum, Harv.

Branches fastigiate, the lesser ones densely ramulose at the tips.

Var. WALTERSII, Harv.

Upper branches distichously compound-pinnate, branchlets patent.

On Zostera and different algæ.

Common in Long Island Sound; Gloucester, Mass.

The forms which have been referred on our coast to C. byssoideum and C. corymbosum are hopelessly confused. Although as described by algologists the two species are sufficient? distinct, in practice it is difficult to say where one begins and the other ends. According to the books, the ramification of the upper branches is dichotomous in C. corymbosum, whereas it is always alternately pinnate in C. byssoideum. In some of the forms of the last-named species, however, the tips are corymbose and the cells of the axis are short and zigzag to such a degree that the tips at least appear to be dichotomous. Of the two species in question, $C$. corymbosum is the less delicate and gelatinous, and is not so decidedly rose colored as $C$. byssoideum, but, as far as our present information goes, although in its typical form $C$. byssoideum is not onl 5 common-apparently more common than in Europe-but also easily recognizable, its extreme forms are not sufficiently well known. The Kützingian method would be to split the species up into four or five new species. According to Crouan and Bornet, this species has seirospores.

C. Corymbosum, (Engl. Bot.) Lyngb. (C. corymbosum, Phyc. Brit., Pl. 272 ; Études Phycol., Pls. 32-35._Pocilothammion corymbosum, Næg.)

Fronds tufted, two to three inches high; filaments very delicate, cortications wanting except at base, main branches several times pinnately or irregularly divided, secondary branches pinnate with dichotomouslymultifid, fastigiate branches which end in hyaline hairs; tetraspores tripartite sessile at the nodes of the branchlets, occupying the place of an ultimate branchlet; antheridia in tufts, sessile on the upper internodes; favellæ binate on the upper part of the branches.

Var. SECUNDATUM, Harv.

Lesser branches frequently secund, ultimate branchlets irregular, scarcely corymbose.

On Zostera.

Halifax, Boston Bay, New London, Providence, Harvey. The var. secundatum, Massachusetts Bay, Greenport, Harvey. 
Wo have only queted the loealities given hy ITarrey, althemegh we have foumd "s hat.

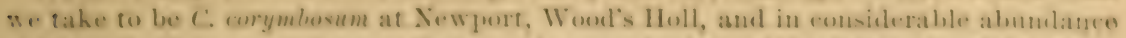
at Xahant, always growing on Zextere. An examination of the different publisherles-

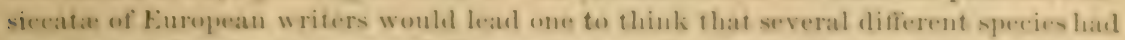
Leen inelnteal under the name of $C$. corymbosum. One might ilonlot whether the firm of Crouan, No. 1:39, and Areschong, No, 15, luelong to the same spereies. At Nahant the same form oecens as that distributed hy fiench algologists.

\section{Dietzis, Hooper.}

- Fronds capillary, pellucidly-articulate nearly to the base, the lower f art percurrent, distichously-pinnate, stem veiny, branches alternate, simple, set at each node with short, alternate, subsimple or pinnatodichotomous plumules, and often terminated by a dense fascicle of ramuli, rachicles zigzag; articulations of the stem six or eight times, of the rachides three or four times, of the ramuli eight or ten times as long as broad; apices subattenuate, obtuse, or subacute; tetraspores elliptical, tripartite, solitary on the uppermost ramuli." (Ner. Am. Bor., Part II, p. 236.)

Greenport, Mrs. Dietz.

Only known through the description given by Harvey in the Nereis. Harrey states that it is related to $C$. corymbosum and C: versicolor. The specimens referred to Wood'y Holl in Proc. Am. Acarl., 1955, p. 376, were probably incorrectly determined.

\section{SUBGExus SEIROSPORA, Harv.}

Fronds erect, main branches corticated; antheridia in tufts on the outer side of short branches; tetraspores tripartite; bispores and seirospores present ; cystocarps destitute of enreloping jelly.

C. seirospermur, Griff. (Seirospora Griffithsiena, Harr., Phyc. Brit., Pl. 21.-Phlebothamnion seirospermum, Kiitz._C. versiculor, var. seirospermum, Harv., in Hooker's Journ. Bot.; Pecilothummon seirospermum, Nieg.)

Fronds dicecions, capillary, two to six inches high, prramidal in outline, main axis percurrent, pinnate with alternate, undivided, lateral, branches, wilich bear secondary branches beset with delicate, erect, dichotomo-multified, corrmbose branches, main branches corticated, smaller branches monosiphonous and byssoid; antheridia in tufts on the outside of short branchlets; tetraspores tripartite, sessile on the upper branchlets, sometimes replaced by bispores; seirospores oral, in moniliform tufts at the ends of the branches; cystocarps composed of racliating chains of spores without gelatinous enrelope (Bornet.)

On Zostera, shells, and stones below low-water mark.

Common throughout Iong Island Souml; Salem, Mass, Marrey. 
One of the commonest and most beautiful of the genus south of Cape Cod, but only known in one locality north of the Cape. It is often brought up on fishermen's nets, and, as a rule, inhabits deeper water than most of the genus. It often attains the height of four or five inches, and is broadly pyramidal in outline. The main branches are rather stout and distinctly corticated, but the ultimate ramifications are very soft and flaccid. With us seirosporic specimens are very common, making the species easily distinguishable, but no form of tetraspore or bispore has been observed on American specimens. According to Bornet, tetraspores, bispores, and seirospores sometimes occur on the same individual. From a comparison of our plant with authentic European specimens there can be no doubt of the specific identity of the two. Accepting the account of the cystocarps given by Bornet, it is extremely doubtful whether the species should be kept in the present genus, and perhaps the genus Seirospora should be restored, not, however, as originally adopted by Harvey.

\section{SPECIES INQUIREND E.}

C. Terue, Harv., Ner. Am. Bor., Part III, p. 130. (Griffithsia tenuis, Ag.)

"Filaments tufted, ultra-capillary, irregularly much branched, diffuse, flexuous, the branches and their divisions very generally secund, springing from the middle of the internodes; ramuli fer and distant, patent, filiform, beset toward the attenuated apices with whorls of minute bys. soid fibers; articulations cylindrical, those of the branches 4-6 times, those of the ramuli 3-4 times as long as broad, and gradually shorter towards the extremities."

\section{Beesley's Point, N. J., Harvey.}

Two specimens which can probably be referred to the present species have been received from Nantucket, one presented by Mrs. Lusk, the other by Mr. Collins. In the absence of fruit the genus cannot be determined. Nægeli, in Beiträge zur Morphologie und Systematik der Ceramiceæ, says that the tetraspores are terminal on a single-celled pedicel. According to Harvey, the species is distinguished by the branches, which are all given off from the middle of the internodes of the branches of the preceding grade. Nægeli says that this species has normal branches like those of Griffthsia barbata, and he regards those given off from the internodes as adventive branches.

\section{Tocwottoniensis, Harv. MSS., fide Bailey.}

\section{Providence, Bailey; Warwick, Hunt.}

As far as we know, this species, mentioned by S. T. Olney in his List of Rhode Island Plants, fortunately for printers and the throats of American algologists, has never been described.

\section{GRIFFITHSIA, $\mathbf{A g}$.}

(Named in honor of Mrs. Griffiths, of Torquay.)

Fronds filiform, monosiphonous, without cortications, dichotomously branching, branches of two kinds, the regetative of indeterminate, the fructiferous of determinate growth; antheridia sessile and covering the upper surface of the terminal cells in tufted whorls at the nodes, or in densely whorled pyramidal tufts on involucrate branches; tetraspores 
tripartite, clustered in inroluerate whorls at the notes or on the inner side of short fascicled branches; eystocarps (farcellar) involucrate.

A lwantiful genns, compriving between 30 and 40 species, but only represented on our lat-tem coast by a single sprecies and on the Western coast by two douldfully detornined species. The genus is distinguished from callithamnion by the iuvolucrate farelle and lig the dispo-ition of the tetraspores. As we hare spermothemnien separated from fallithamnion in consequence of the alsernce of the gelatinous envelope found in true favelle, so we have liormeta separated in a similar way from Griffithia. The genus can generally be recognized at sight hy the rather large hut very delicates cylindrifal, oxal, or, at times. gloluse cells, which (h) not lwar immersion in fresh water even for a short time, and loy the liranehing, which is dichotomons or a modification of the dichotomons tyje. The accurate specific deternination from sterile specimens alone is generally impossible, so great is the resemblance of the fromels in the difti-rent species. The antheridia vary very much in the different speecies. In onr only sprecies they are sessile on the upper half of the glohuse terminal cells: in fi. corcullina they surround the modes in tufts; and in $(\dot{b}$. setucen they are in dense approximate whorl, attached to the inner side of incurved hranchlets. The tet raspores also vary in the different species. In G. Iiornetiana and $G$. corcullina they are in whorls at thes nocles, and are attacled to the inner side of short simple branches, which form a whorl around the note. In $(\dot{r}$. setacen the tetraspores oceupy a position which corresponds to that of the antheridia. The favellae are always truly involucrate and, as far as is known, terminal, in our species occupying the place of a suppressed dichotomy. The development of the procarp of $C$. corullina has been fully studied hy Janczewski. In that species he found two trichogrynes to each carpogenic system, as is also the case in the genus Ceramium. A non-sexual mode of propagation, by means of cells which give off root-like processes, has been described by Janczewski in $C$. corallina, and a similar process takes place in G. Bornetiana.

G. Bornetiaxa, Farlow. (G. comallinu? Ilarv., Ner. Am. Bor., Part II. 1. 22S, non A gardh.-G. globulifera, Kiitz., Tab. P'hyc., Vol. XII, P'l. 30.-G. globifera, J. Ag. in part.-G. Bornetiana, Proc. Am. Acad., $187 \%$.)

Exs.-Alg. Am. Bor., Farlow, Anderson \& Eaton, No. 88.

Fronds diøcious and dimorphous.

Male PLAxt.-Globosely tufted, one to three inches high; filaments repeatedly dichotomous; lower cells eylindrical-obovoid, several times longer than broad, becoming shorter and broader abore; terminal cells glohose-pyriform; antheridia sessile, densely covering the upper half of terminal cell. Pl. X, Fig. 4.

Finale PLANT.-Two to five inches high, loosely tufted, filaments rejeatedly dichotomous; lower cells crlindrical-oboroid, becoming broadly pyriform above and then gradually diminishing in size toward the tip; firrellie solitary on the uppere part of the superior cells; cells of involuere 10-20, unicellular, club-slaped, somewhat incurved. Pl. XI, Fig. 3.

Tivrasporic I lant.-More slender than the female plant; tetraspores tripartite, densely clnstered around the nodes of spereial luanches; cells of inrolncre short and suberect. Pl. X, Fig. 5.

Un wharves, sponges, shells, and occasionally on Zosteru. 


\section{Common from Nantucket southward.}

A summer plant which attains perfection duriug the month of July, disappearing later in the summer. It is sometimes found washed ashore in large quantities after a storm. The species has been known for some time, but until recently it has passed for a form of $G$. corallina, a species common in Europe. It differs from that species in sereral respects. The antheridia form a sort of cap over the top of the terminal cells of the male plant, which is considerably smaller than the female plant and has a different habit, in consequence of which it was called a variety, var. globifera, by Harres. The female aud tetrasporic plants more closely resemble the true G. corallina. They do not end in large globose cells, as in the male plant, but the largest cells are below the tip, which is tapering and acute. When the tetrasporic plant has narrower and more acute cells than usual it constitutes the var. tenuis of the Nereis. The slenderest specimens, however, are usually sterile. In the structure of the procarp this species differs cousiderably from G. corallina as described by Janczewski. There is only one trichogrne instead of two, as in the last-named species. The procarp begins by the growth of a hemispherical cell at the upper part of an articulation. The cell is then divided into two parts by a partition parallel to the base. It is from the lower cell thus formed that the involucre is formed, and from the upper arise the carpogenic cells in the following way: By usually four oblique partitions there are formed four external hemispherical cells and a central pyramidal cell with a broad base. By subsequent division of one of the hemispherical cells, generally of the one lying nearest the axis of the plant, there is cut off a cell which divides into three smaller granular cells, the upper of which grows into a trichoggne. The spores are formed by the subsequent growth of the other three hemispherical cells. There are two sets of hair-like organs which arise from the upper border of the cells in this species; one set is short and granular, consisting of a cuboidal basal cell with short corymbose filaments; the other set occupies a similar position, but the hairs are long and hyaline, consisting of a long basal cell, which bears at its apex a whorl of three or more cells, which in turn bear other whorls, the whole hair being several times compound.

\section{HALURUS, Kütz.}

(From $a \lambda s$, salt, and $o v \rho a$, a tail.)

Fronds monosiphonous, branching, beset throughout with short, approximate, incurred, di-trichotomous, whorled, secondary branches ; tetraspores tripartite, attached to the inner side of special branches, arranged in whorls one above another; antheridia in similar position, forming closely verticillate tufts; favellæ terminal on short branches.

A genus composed of one, or according to some writers two, species, separated from Griffithsia principally by the character of the frond.

H. Equisetifolius, Kütz. (Griffithsia equisetifolia, Ag.; Phyc. Brit., Pl. 67.)

Fronds four to eight inches long, arising from a disk, irregularly branching, secondary branches trichotomous below, dichotomous abore, much incurved, densely corering the branches, rhizoidal descending filaments given off from some of the lower branches.

\section{Brooklyn, N. Y.?}

A plant resembling a Cladostephus, except that its color is a dirty red. The species is very doubtfully known on our coast. It is mentioned in the Nereis as having been sent to Harvey by Mr. Hooper, of Brooklyn, but there is no definite information as to the locality where the plant was collected. 
PTILOTA, Ag.

$$
\text { (From } \pi \text { Ti.w.os, feathered.) }
$$

Fronds compresised, ancipital, decompound, branches distichous, peetinate-pinnate, romposed of a monosiphonous pinnate axis of larger qualrate cells and a cortex of smaller cells; antheridia terminal on short corymbose branches; tetraspores tripartite; cystocarps (fitrellie) terminal on the branches, usually involucrate.

An easily recognized grenus. comprising about twenty species, of a derpered or maldish-lirewn color, only scantily represented on our coats, but represented on the C:alifomian coast by a number of heantiful species. The genus reaches its greatent derelopment in Australia. The growth is by an apical cell, from which arises a monosplomous axis of indefinite growth and short secomlary lianches. The origin of the cortinations has heen fully explained ly Nagreli in Die neuern Algensysteme, page 206. The momosphonous axis is clearly seen on holding specimens up to the light, and is alo ri-ible at the growing tips where the cortications are wanting. The cortications (1) not firm a true solid tissue, lut rather, as shown by Nageli, densely interwoven branching filaments. A detailed account of the development of the frond in different epecies is given by Cramer in Physiologisch-systematische Lntersuchungen iber die Ceramiacen. The development of the procarp is given by Bornet in Notes Algologivnes, page 15. The position of the tetraspores is variable, and serves as a specific mark.

P. Elfadxs, Ponnem. (Ptilota sericen, Harr, Phyc. Brit., Pl. 191.$P . p l u m o s a$, var. tenuissima, Ag.)

Fronds brownish red, three to six inches high, main branches filiform, irregularly branching, secondary branches compressed, closely pinnate, with oplosite pinnate branchlets, ultimate divisions without cortication; farellie terminal on the branches, irregularly lobed, naked or with a short involuere; tetraspores solitary on the encls of the loranchlets, at first tripartite, becoming polysporic.

On the under side of rocks between tide-marks and on shells and algre in deep water.

\section{Throughout our whole limit; Europe.}

A much more delicate species than the next, and recugnized at once liy the fart that the sonner parts of the hranches are without cortications, whereas in the next opecies the cortications extend nearly to the apex. It also diflers in the position of the tetrasporm, and the farella are usnally naked, while in the following species they are surroumbed and almost concealed liy a well-marked involucre. The usual color is a grayinh biak, lut in falling it often becomes pinkish. North of Cape Cod the sprecies is womally foumd clinging to the umler surfaces of rocks at low-water mark, in company with Ciramium IImperi, Rhodochorton Liothii, and Syluacelaria radiouns. In such situations the speeimens are small. At Newpert and Gay Heal the plant attains a morh larger size, and is abumlantly wasled asluore frum deep water.

\section{P. SERRATA, Kuitz.}

Fronds dark red, three to six inches long. compressed, ancipital, decomponnd-pinnate, pinna opposite, one pinna being short, undirided, 
straight or falcate, sharply serrate, especially on the lower side, and the opposing pinna pinnately divided or compound; pinnæ nearly at right angles to the axis, apices acute; tetraspores borne in dense ellipsoidal cluster either at the ends of the simple pinnæ or ou the serrations and tips of the compound pinnæ; tetrasporic masses interspersed with monosiphonous incurred branches; farelli in similar position to the tetraspores, nearly concealed by the large, incurred, usually serrate dirisions of the involucre.

On algie, especially on stems of Laminaria, below low-water mark.

Common north of Boston; Thimble Islands, near Tew Haren, and dredged off Block Island, Prof. Eaton.

A common and characteristic alga of our northeru coast, extending through Greenland to the northern coast of Europe, and also foumd in the North Pacific. The present species, together with Euthora cristatu and Delesseria sinuosa, form the greater part of the specimens collected for ornamental purposes by ladies on the Northern New England coast. $P$. serrata, when dried, is usually rery dark colored, unless it has previously been soaked for some time in fresh water, and it does not adhere well to paper unless under considerable pressure. It cannot be mistaken for ans other species growing on cur coast. Whether it is a rariety of $P . p l u m o s a$ is a question about which writers do not agree, but, although in this connection our form has been kept as a distinct species, it is highly probalyle that it is really nothing more than a coarser northern form of $P$. plumosa. The typical form of P. plumosa is certainly unknown in New England. The trpe is more slender, and the pinna are pectinate, not serrate. The position of the fruit is the same, the principal difference being in the more strongly marked inrolucre of the favelle and in the tetraspores, which are borne on densely fastigiate branches, which hare no cortications, and some of which are incurved and project beyond the general sporiferous mass. In $P$. plumosa the tetraspores are also borne on the tips of monosiphonous brauches, but they are not densely conglomerate, nor are the projecting incurved ramuli prominent. The present species is rery rare south of Cape Cod, being known in only two localities and in a much reduced form.

\section{CERAMIUM, Lyngb.}

\section{(From кераньоv, a small pitcher.)}

Fronds filiform, dichotomous or occasionally subpinnate, monosiphonous, composed of a series of large orate or quadrate cells, with bands of small corticating cells at the nodes, and in some species also extending orer the internodes; antheridia forming sessile patches on the upper branches; tetraspores tripartite, formed from the corticating cells; cystocarps (favellæ) sessile at the nodes, usually inrolucrate.

A unirersally diffused and easily recognized genus, of which, however, the species are by no means easily recognized. The genus is distinguished by the monosiphonous, dichotomous frond, with bands of small corticating cells at the nodes, or, in some cases, corering the internodes as well. The tips of the flaments are forked and usually decidedly incurred, whence the generic name is derived. The apical growth and formation of the cortex is fully detailed by Nægeli and Cramer in Pflanzeuphysiologischo Untersuchugen, Part IV. The procarp in Ceramium is furnished with two trichogrnes and a single carpogenic cell formed from the cortical cells on the convex side of the 


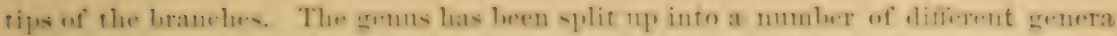

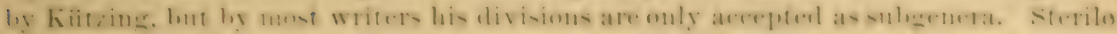

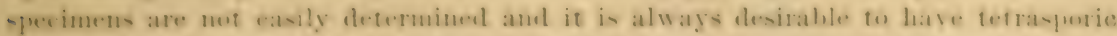

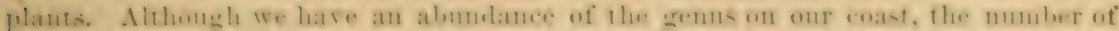
frecies is complaratively small, and the group of sper ies lassing spines at the neeles is, as far as is henw $n$, quite wanting.

SECT. I. Fronds without spines, corticul cells derument fiom the noules and mare or less completely covering the internodes.

\section{C. rubrux, Ag. (C. rubrum, Phyc. Brit., Pl. 181.)}

Fromels rohust, diehotomous, suhfastigiate, hranches erect, appices inenrved or forcipate, noles contracted helow: tetraspores in irrecrular series at the noules, immersed ; farellat lateral, solitary, with a short inroluere.

Var. pron

Fromls heset wn all sinles with numeroms, latteral, simple or forked lianchlets.

Var. Secundatem, Ag.

Branchlets generally secund.

Var. squarrosum, Harr.

Fronds small, regularly dichotomous, fiatigiate, with rery few, short, lateral branchlets, lower divisions distant, spreading, upper divisions rlose together, widlely spreading, apices often revolute.

Everywhere common; var. squarrosum on Zostera, Massachusetts Iay.

A nhipnitum and rariahle species, of which we have enumerated only the principal fums. The typual form is easily recognized, and the same is true of most of the rate tie ties. The var. dewrens has the internodes partly naked, especially in the upre.r 1'att. The var. derumens of the Nereis is referred liy Agardh to the next species, and is distingnished from the true var. derurrens of C. ruhrum, which has immersent tertra-peres, ly the large tetraspores arranged in a regular circle at the nonles and projecting decidedly abore the surface.

\section{CIRCINNATUM, Kiitz.}

Fromds setaneous, dichotomous, fastigiate, divisions erect, latent. apores forcipate, internodes partly corticated by the cells which are rlecurrent from the nodes; tetraspores large. projecting in a ring ammor the upper nodes.

Gleneore, L. I., Mr. Foung; Dartmouth, Mass., Miss Introulum; Magnolia, Mass., Mrs. Bray.

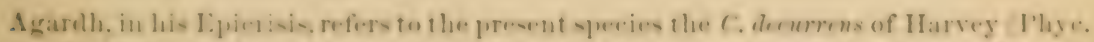

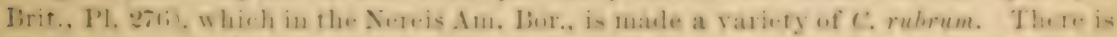

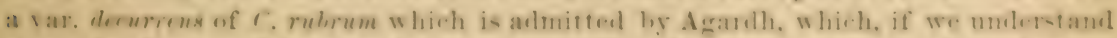
correctly, has small immersed tetraspores. This firm eccurs ales wirle us, lut we hase no untes as to the locality. To the present species we refer forme in whirh the

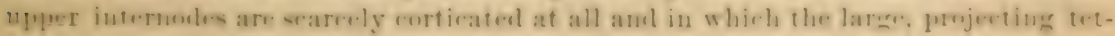
raspores are in a single ring at the upper nodes. 
SECT. II. Fronds without spines, cortical cells confined to a definitely lim. ited band round the nodes, the internodes diaphanous.

C. Diaphanum, Roth; Phyc. Brit., Pl. 193.

Fronds brownish red, filaments two to four inches high, loosely tufted, main branches setaceous, rather stout, distantly forking, beset with short, lateral, dichotomous branchlets, apices incurved; tetraspores immersed, in whorls at the nodes; farellæ lateral, involucrate.

Nahant, New Bedford, Mass.; Providence, R. I.; New York Bas, Harvey; Europe; California.

The localities given are quoted from the Nereis. As far as our own experience goes, the present species is of rery infrequent occurrence on the New England coast, although we have specimens collected at Lynn, Mass., and others from the ricinity of New York, collected by Mr. A. R. Young, which may possibly be referred to C. diaphanum. In almost all cases the C. diaphanum of American collectors is the C. strictum of the Phycologia Britannica a species closely related to the present, and agreeing with it in the fructification, but differing in ramification. C. diaphanum has rather stout leading branches, which are beset with secondary dichotomous branches which are alternatels giren off from the main branches, and which are much finer than the main branches, the tips being capillary. The general outline of the frond is pyramidal, and that of the principal branches and their ramifications is oval-elongated. In $C$. strictum there are no leading branches, but the filaments are of a pretty nearly uniform diameter, regularly dichotomous throughout, and form globose tufts. Both species differ from our other species, except C. Hooperi, in being of a brownish-purple rather than of a distinctly rose-colored tint, and both adhere closely to paper in drying.

C. stricten, (Kiitz.) Harr. (C. strictum, Phyc. Brit., Pl. 334.-Gongroceras strictum, Kütz.)

Fronds brownish red, filaments capillary, two to six inches high, densely tufted, branches uniformly dichotomous throughout, divisions erect, fastigiate above, apices forcipate; tetraspores immersed, whorled at the nodes.

\section{On Zostera and other marine plants.}

\section{Common from New York to Cape Cod.}

This species forms large tufts at the base of Zostera in warm, shallow bays, and is often in company with Polysiphonia Olneyi. In the Little Harbor at Wood's Holl it is found in large guantities, after a heary blow, lying unattached on the mud, just below low-water mark.

C. Hooperi, Harr. (C. Hooperi, Harr., Ner. Am. Bor., Part II, 1. 211.-C. Destongchampsii, Farlow, in Report U. S. Fish Comm., 1875.)

Fronds dark purple, one to four inches high, filaments procumbent and densely interroven at base, above dichotomous, with short, erect, irregularly placed lateral branches, apices straight, erect, cortical cells forming a sharply defined band at the nodes, axile cells short above, becoming twice as long as broad below; rhizoidal filaments unilateral, 
single at the mules, numerous, usually unicellular, often ending in irregular diskis; tetraspores in a cirele at the nodes, immersed in the cortical cells: favellex?

Forming tufts on mul-eorered rocks at low tide.

Xew Haren, Prof. Eaton; near New York, Mr. Young; Xewport, I. I.; common from Nahant to Eastport.

This speries is not, as Harrey and $\Lambda$ gardh supposed, rery distinct, but, on the contrary, ean scarely be distinguished from $C$. Deslongchampsii, except in the tetraspores, whirh are inumersel, not projecting as in that species. Buth species inhabit similar levalities, both are derep purple in color, are procumbent at the base, and have numerons rhizoicls: the hranching and ereet tips are the same in both. Furthermore, as it oceurs with us, C. Hooperi not unfecuently hears precisely such irregular lootryoidal masses as are found on C. Deslongchampsii in Enrope, and which are figured in the I'hycologia liritannica. Harvey, as well as Natgeli and Cramer, douhts whether these masses are really favellat, and, judging from American specimens, they are more probably monstrosities. In one case we found the distortions on a specimen hearing tetraspores, and Nirgeli and Cramer have observed a similar case, a.presumption against the favelloid nature of the swellings. Fully-matured tetraspores are to be desired, and it maly be that they will be found to be prominent, as in $C$. Meslungchampsii, in which case the validity of the species would be more than doubtful.

\section{Fastigiatum, Harv., Phye. Brit., Pl. 255.}

Fronds lake-red, densely tufted, two to five inches high, filaments eapillary, dichotomous throughout, divisions erect, level-toplerl, apices erect or slightly incurved; tetrasjores secund on the outer side of the lianches, prominent ; fivellae small, lateral, with a short involucre.

\section{On Zostera.}

\section{Massachusetts Bay; Greemport ; Newport; Long Branch, Ilurey.}

This species is at present a puzzle. In American herbaria one frequently finds specimens labelled $C$. fustigiatum, and some specimens bear Harrey's own hamlwriting. Infirtunately, the species is persistently sterile, for we have only twice fumbl tetraspores in what seemed to be this species, and sterile specimens are hardly snfdieient for determination in the grenus Cerumium. What was apparently considered ly Harvey to be his $C$. fustigialum is common south of Cape Cod amel forms leatutiful tufts on Zestera. The color is a lake-red, the filaments are all capillary and regularly dichotcunons, the npper segments being level-topped, so that when spread on paper the species laas a regular outline. The apiees are erect, not rolled inwaris at the tip, and short rhizoilal proenses are given off from some of the noules. Harvey states that the tetraspores are prominent and secund on the outer edge of the branches, while Agarilh says they are whorled at the norles. In one specimen we found them as deecribed ly Ilarvey. It must be admitted that when sterile the species approaches ton nur $C$. tenuissimum, and it is much to be desired that a large sot of fruiting specimens he cramined to settle the dlisputed question of the tetraspores. C. fastigietum is a speries apparenty not well kowwn to contiuental lutanists, whe serem to lase at times included it in other species without reference to British specimens. With us it is common, althongh, consihering that there may he a dombt alont the de-termination, we have only quoted the lowalities given hy Harreg. By Agardh $C$ f fustigiutum is considereel closely related to C. Meslengchampsii, lut julging by Harveran specimens, luth from Ireland and New England, we can hardly think that the two speries are imuediately related. 


\section{C. corymbosum, Ag.}

"Fronds capillary, rather regularly decompound-dichotomous, branches erecto-patent, corymbose, fastigiate, apices forcipate, lower joints four to five times longer than broad, upper joints subequal; tetraspores naked, emergent, secund on the outer side of the branches, lower portion resting on the cortical layer." (Agardh, Epicrisis, p. 93.)

Atlantic coast of North America.

This species is said by Agardh to resemble $C$. fastigiatum in its ramifications, but with more expanded branches, and to differ in having a violet color and a different arraugement of the tetraspores. From this it would appear that the two species are practically distiuguished by the different position of the tetraspores. With regard to their position in C. fustigiatum, as has already been said, Agardh and Harvey do not agree.

\section{Tenuissimum, (Lyngb.) Ag.}

Fronds rosy-red, two to four inches high, deusely tufted, capillars, decompound-dichotomous, branches erect, patent, apices forcipate ; tetraspores borme on the swollen nodes, usually on the onter side, often several together; favellæ lateral, involucrate.

Var. ARACHNOIDEUM, Ag.

Fronds more slender than in the type, tetraspores exserted, secund on the outer side of the branches, solitary or sereral together.

Var. Patentissiyum, Harv.

Fronds small, dichotomies distant and patent, the branches ending in dichotomo-multifid, divaricating, corymboso-fastigiate branchlets.

On Zostera and algæ.

Common in Long Island Sound; Gloucester, Mass., Mrs. Davis; Europe.

The present species, according to Agardh, includes the $C$. nodosum of the Phycologia Britannica, but Harvey's plate certainly does not correctly represent the tetraspores of the typical form of the species. In the type the nodes are swollen, especially on the upper margin, and the rather large tetraspores project beyond the cortical cells, usually on the outer side of the node, and there are frequently from two to four together. In the var. arachnoideum the tetraspores become almost naked, being only slightly covered by the cortical cells in their lower part. The var. patentissimum of Harvey has a somewhat different ramification from the type. It must be admitted that the limits of $C$. tenuissimum are not well marked, and it may be that in the present case wo have confused two distinct species.

C. CAPri-Cornu, (Reinsch). (Hormoceras Capri-Cornu, Reinsch, Contrib. ad Alg. et Fung., p. 57, Pl.47._C. Youngii, Farlow, Rept. U. S. Fish Comm., 1875.)

Fronds brownish purple, one to three inches high, filaments setaceons, repeaterlly dichotomous, divisions erecto-patent, ultinate divisions sub- 
fistigiate, apices much incurved, branches beset throughout with rery short incurved or recurred branchlets, cells in upper part scarcely as long as broal, two to three times as long below, corticating cells forming a sharply defined band at the nodes: tetraspores and farellat?

In eight feet of water.

\section{Canarsie, L. I., 11r. A. R. Young.}

This eurions speries has unfortmately merer heen foume in fruit. We have only seen three speciunens, which were all collereted hy Mr. Joung. The largent was abont three inches high and the tilaments were coarser than these of $C$. diaphenum and $C$. stielum. It is easily recognized ly the numerons short incurved branchlets which arise singly or in twos and threes at the nemes. It is pussible that a large series of specimens would have shown that the present is a form of some ofluer species, but

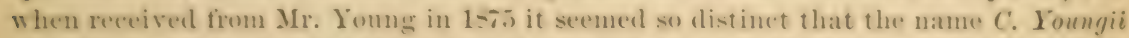
was given to it, and unler that name it was mentioned in the Rejort of the U.S. Fish Commission for $1=\mathbf{5}$, but without any description. The IIormoceras Capri-Cormu of Reinselh, from Anticonti, julging from the plate and deseription in the Contributiones, pulblished in 1-it-75, is apparenty the same as $C$. Fonngii, and the name of Reinsch las the priority.

\section{SUBorder SPYRIDIE.E.}

Fronds filiform, monosiphonous, formed of longer branching filaments of incleterminate growth, from which are given off short, simple branches of deterininate growth, cells of main filaments corticated throughont, the secondary branches corticated only at the nodes; antheridia borne on the secondary branches, arising from the nodes and finally covering the internodes; tetraspores tripartite, borne at the nodes of secondary branches ; cystocarps suliterminal on the branches, consisting of obovate masses of spores in dense whorls around the central cell, with a pericarp formed of monosiphonous filaments packed together in a gelatinous substance.

An order eonsisting of a single grenus and a small number of species, most of which are tropical. The systematie pesition of the order is a matter of clispute. The fronds resemble closely those of the Ceramica, as do also the tetraspores, but the cystocarpes are pertuliar and not closely related to those of any other order. A section of the mature fruit, which is usually either two or three parted, shows a monosiphonous axis, aroumb the upper cells of which the spores are arranged in irregularly whorled groups. The whele is surrounded hy a wall, which is formed loy the union, ly means of a jelly, of the elongated tips of subliehotomons filanents which arise from the cortical cells of the nodes just below the sporiferons cells. The anthericlia are first furmed at the nowes, but soon extenul over the internodes for a considerable distance. The devel-

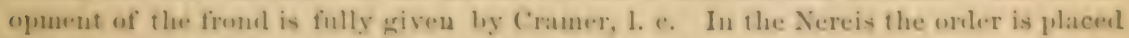
next to Ceramianen, and in the Lpierisis of Acardh between the Dumontiaced and the Areschougiece. 


\section{SPYRIDIA, Harv.}

(From $\sigma \pi v \rho \iota$, a basket.)

Characters those of the genus.

S. fillinentosa, Harr., Phyc. Brit., Pl. 46. Pl. X, Fig. 1, and Pl. XII, Fig. 2.

Fronds filamentous, in expanded tufts four to eight inches high, branches irregularly placed, spreading, repeatedly dirided, secondary branches subequal, spirally inserted, ending in a mucronate tip composed of two or three hyaline cells; tetraspores tripartite, sessile at the nodes of branchlets, solitary or clustered; cystocarps two or three lobed.

Var. Refracta, Harr., Ner. Am. Bor., Part III, Pl. $34 a$.

Fronds robust, subdichotomous, the branches naked, divaricating, with rery wide axils, arched, the terminal ones frequently revolute.

On Zostera, wharres, and mud below low-water mark.

Common from Cape Cod southward; Massachusetts Bay, Harvey; most warm seas.

Rather a beautiful species when growing, but which becomes brownish in drying and does not adhere very well to paper. It does not collapse when remored from the water, but remains corered with drops which adhere to the branchlets. The branches, although rather coarse, are brittle. The species is more common in Long Island Sound than in Europe, certainly than on the Atlantic coast. It mas be recognized under the microscope by the monosiphonous corticated branches and hyaline branchlets, corticated only at the nodes and with a mucronate tip. The antheridia, of which, so far as we know, no description has hitherto been giren, surround the branchlets, corering sereral cells near the base. Thes arise from divisions of the cortical cells, which form closely packed, short filaments, and extend over the internodes, those from the different nodes becoming contluent. The indiriduals which bear the cystocarps are distinct from those which bear the antheridia, and may be recognized by their more dense habit.

\section{Suborder CRYPTONEMIE E.}

Fronds solid or becoming hollow with age, cylindrical, compressed or membranaceous; antheridia forming superficial spots or small tufts; tetraspores usually cruciate and scattered in the cortical layer, sometimes in localized spots; çstocarps consisting of a single mass of irregularly placed spores surrounded by a gelatinous enrelope, but not prorided with a special cellular pericarp, immersed in the substance of the frond, spores discharged by a narrow passage formed between the cells of the cortex.

An order comprising about 14 or 15 genera and between 125 and 150 species, most of which are inhabitants of warm seas, and rary in consistency from subgelatinous to coriaceous and cartilaginous. Our only two species belong to the tribe Nemastomer. There are numerous species on the Californian coast, nearly all difficult of determina- 
tim owing to the great variation in shape. The suboriler approaches very alosely to the Ceramien, since the eysterarps are in many of the species true favella, which, instead of leeing naked, are concealed in the frouds. It is in fact mere!y an arbitrary matter whether one places Gleiosiphonia in one suboriter or the other. The fronds are

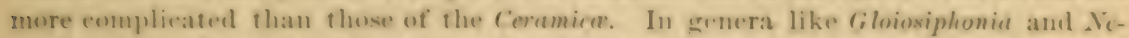
mestoma there is an axis formed respectively of a monosiphonous tilament or lundle of filaments, and an ill-defined cortex formed simply of the loosely united laterai filaments. In other genera, as in Iulymenia, the cortex is more distinetly marked, and in Prionilis and Cryptonemia the frond is dense and coriaceous.

\section{GLOIOSIPIIONIA, Carm.}

(From yioıs, sticky, and $\sigma \iota \omega \omega \nu$, a tube.)

Fronds monocious, gelatinous, eylindrical, branching, solid above, and formed of a monosiphonous axis, whose cells in their central portion bear whorls of four secondary branches, which divide so as to form umbels, which collectively form the cortex; descending filaments formed from the lower part of secondary branches; lower portion of fronds hollow; tetraspores eruciate, borne at the summit of the cortical filaments; antheridia forming spots on the surface of the fronds; cystocarps borue on the lower part of the cortical filaments, consisting of tufts of branching, radiating filaments densely packed in a single mass and surrounded by jelly.

A genus containing but a single certainly known species, found both in Europe and this conntry. The genns has leeen placed by some writers in the Cryptonemied and by others in the Ceramied. It in fict connects the two suborders, the fruit being a favella in which the spores all arrive at maturity at the same time, forming, in the terminoloury of some algologists, a simple nucleus. The ripe eystocarps are concealed in the fruml, as in the Cryptonemict, but, on the other haud, the structure of the sn-called cortical layer is like the outer portion of Dudresnaya, which is generally placed in the Ceramier. A detailed acconnt of the clevelopunent of the cystocarp in G. capillaris will be found in Notes Algologiques, p. 41.

G. Capillaris, Carm. (G. capillaris, Carm., Phyce. Brit., Pl. ji; Notes Algologiques, Pl. 13.)

Fromls grelatinous, four inches to a foot long, solid above, hollow below, main branches subsimple, terete, naked below, densely beset aboro with decompound lateral branches, branchlets tapering at both extremities; eystocarps abundant, frequently forming nodosities.

In pools below low.water mark.

New London, Harrey; Nahant, W. G. F.; Chelsea, Miss Brever; Gloucester, Mrs. Bray and Mrs. Daris; IIampton Beach, Dr. Durkee; Peak's Island, Maine, Prof. Goode.

A widely diffused but loeally rare species, found in early summer and disappearing in Angust. It is easily recognized at sight by its delicate gelatinous sulstance and brilliant rose color and by the tapering liranchlets. Cystocarpic specimens are not unfrequently found, lut tetra-purie plants are rare and have never been olserved in this county. The species shrinks very much in drying and actheres closely to paper. 


\section{NEMASTOMA.}

(From $\nu \eta \mu \alpha$, a thread, and $\sigma \tau o \mu \alpha$, a mouth.)

Fronds gelatino-carnose, compressed-eylindrical or plane, dichotomous or subpinnate, composed of an axial layer of densely woren longitudinal filaments, from which are giren off short, lateral, dichotomous, fastigiate filaments, which are united by a gelatinous substance to form a peripheral layer; tetraspores cruciate, borne in the peripheral layer; antheridia borne on the superficial cells of the periphery; cystocarps (farellæ) buried in the peripheral layer, spores escaping by a narrow opening between the peripheral filaments.

A genus comprising not far from a dozen species, which inhabit principally the warmer waters of the globe, the genus being particularly well represented in Australia. The fronds of the different species vary from only slightly compressed and linear to broad and palmate, and in G. marginifera the frond resembles in shape that of Rhodymenia palmata. The substance is rather gelatinous and the microscopic structure resembles very closely that of the fronds of some of the Nemaliex. The fruit of N. marginifera is described by Bornet, in Notes Algologiques, as being a true favella like that of Callithamnion. The genus is generally placed near Gloiosiphonia, and, like that genus, closely connects the Ceramieo with the Cryptonemeo.

N. (?) BaIrdir, Farlow, Proc. Am. Acad. Arts and Sciences, 1875, p. 351 .

Fronds purplish-rose colored, gelatinous, four inches long, one inch wide below, vermiform, once or twice dichotomously divided, axils acute, apices attenuated; tetraspores cruciate, borne on the tips of the peripheral filaments; cystocarps

Washed ashore at Gay Head, W. G. F.

A rery rare species, of which only a single specimen is known. It was found on the beach near the light-house at Gay Head, Mass., in company with Scinaia furcellata, in August, 1871. The specimen was a fragment, without the base of the plant, but with abundant tetraspores, which were borne on the tips of the peripheral filaments. In the absence of cystocarpic specimens the genus cannot be ascertained with certainty, and botanists who visit Gay Head, should seach for the plant by dredging off the Devil's Bridge in five to ten fathoms. The specimen collected was at first supposed to be a portion of a broad specimen of Nemalion purpureum, a species not yet known on our coast. The peripheral filaments are loosely united together by a gelatinous mass, as in the subgenus Gymnophloea of Agardh.

\section{Suborder DUMONTIE E.}

Fronds tubular, branching or proliferous; cystocarps immersed in the frond, composed of a single mass of irregularly placed cells, similar in most respects to those of the Cryptonemiece.

A small suborder, included by Harrey in the Cryptonemiex. The derelopment of the cystocarps is not well known, and on our coast there is no material to be obtained for the study of the suborder. The common Dumontia filiformis of Northern Europe is wanting with us, and the genus Halosaccion, of which we have one representative, 


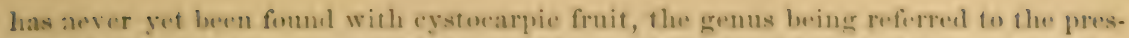
ent suborder in conserpuence of the resemblance of the frond to that of Dumomties. $\Lambda \mathrm{c}$ cording to lbornet, the spores in 11 . filiformis are borne directly on the carpugende coll, whereas in the nearly related grenera of cryptememied there are sterile cells between the spores and the carpogenic cell.

\section{HALOSACCION, Kiitz.}

(From $a \lambda_{s}$, the sea, and oakкıv, a small sack.)

Fronds hollow, tubular or sack-shaped, simple or proliferously branched, consisting of an internal layer of large, roundish, angular, colorless cells, nstnally arranged in linear series and packed closely together by a gelatinous substance; tetraspores cruciate, immersed in the cortical layer; cystocarps?

A small genus, incluling about ten speceies, of which $I I$. ramentaceum is common in the Xorth Atlantic, the other species being confined to the North Pacific and extemling as far south as California on the east coast and Japan on the west coast. The species are all coarse and somewhat cartilaginous, and are either in the form of elongated obovate sacks or tubular and proliferous. The cystocarpie fruit is unknown, and the grenus is placed conjecturally near Dumontia in consequence of the structure of the frond.

II. Ramextaceurr, (L.) Ag. (II. ramentaceum, Ner. Am. Bor., Part II, Pl. 29 a.-Ulia sobolifera, Fl. Dan., Pl. 356.)

Fronds brownish purple, six to fourteen inches high, eylindrical-compressed, attenuated at the base, simple or irregularly branched, more or less densely beset with seattered or crowded, simple or forked, lateral mwliferations; tetraspores large, spherical, cruciate ; cystocarps?

Var. Gladiatcm, Eaton, Trans. Conn. Acad., Vol. II, p. 347.

Proliferations long, simple, somewhat incurved, inflated.

On algae in deep pools and on mud-covered rocks at low-water mark.

From Gloucester, Mass., northmard ; North Atlantic and Pacific. The variety at Eastport.

A characteristie species of our northern coast, occasionally found at filoucester and lucoming very common at Eastport. The fronds are very variable in shape, yet, on the whole, easily reengnized. The most marked form is the var. gladiatum. The robustness depends a good deal on the place of growth. In exposed pools the fronds are short and very densely proliferous; in sheltered harbors, like that of East port, the froliferations grow long, and are of rather delirate texture, approaching $I I$. microsporum. which harelly seens a distinct species. Kjellman, in Spetzbergens Marina klorofyllürande Thallophyter, mentions certain hemispherieal protuberances on the fronds of this sleries, and the same are found on our coast. As before stated, the specimen of Aspromonus comprissus credited to Glomester, Mass., was an error, the specimen lwing in reality a sterile and partly bleached Haloxaccion.

\section{Stborder GiGArTinex.}

Fronds terete, compressed or membranaceons, flesly or cartilaginous; anthericlia in superficial spots or sunk in small erypts: tetraspores 
cruciate or zonate, usually collected in nemathecia or in superficial spots (sori), sometimes scattered; cystocarps composed of numerous masses of irregularly placed spores, between which are found portions of the tissue of the interior of the frond, the whole sporiferous mass being corered by the swollen surfaces of the frond, which are sometimes raised in subspherical conceptacles; spores discharged through special carpostomes.

A large suborter, comprising species which are sometimes more or less cylindrical in shape, but which are more frequently expanded and of a coarse, subcartilaginous consistency. Some of the largest Floridece are found among the Gigartinea, and perhaps no other suborder contains so many ill-defined species as the present. Owing to the thickness and opacity of the fronds, the study of the development of the cystocarps is attended with very great difficulty, and as jet no full account of the formation of the fruit of any of the species has been published. In the Notes Algologiques, Bornet, however, gives a brief account of the formation of the cystocarp in Gymnogongrus patens. In all the species the spores are irregularly grouped in several distinct masses, which are imbedded in the tissue of the frond, the cells of which undergo a change as the spores ripen, their walls becoming thick and lamellated, and traversed by numerous small canals. In Callophyllis and some other genera the sporiferous mass and the enveloping tissue of the frond form subglobose swellings external to the surface of the fronds, but in other genera, as Gymnogongrus, the sporiferous mass occupies the central part of the frond, which swells on all sides. The cystocarps discharge their spores through carpostomes or narrow canals formed in the cortex of the fronds. Sometimes there is a single carpostome, but in some genera, as Gymnogongrus and Ahnfeldtia, there are several.

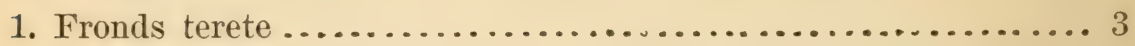

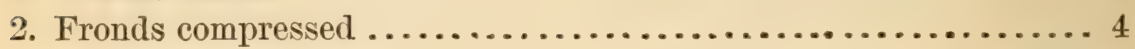

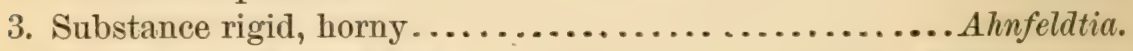

Substance soft, succulent..................... Cystoclonium.

4. Fronds thin, leaf-like .......................... Phyllophora.

Fronds cartilaginous or subcartilaginous................ 5

5. Cystocarps external in special leaflets ............... Gigartina.

Cystocarps immersed ........................... 6

6. Central part of frond composed of roundish poljgonal cells.

Gymnogongrus.

7. Central part of frond formed of slender anastomosing filaments.

Chondrus.

\section{PHYLLOPHORA, Grev.}

(From $\phi v \lambda \lambda o v$, a leaf, and $\phi \varepsilon \rho \omega$, to bear.)

Fronds stipitate, stipes expanding into a rigid-membranaceous, flat, simple or eleft lamina, proliferous from the disk or margin, composed internally of oblong polygonal cells, with a cortical layer of minute, colored, vertically seriated cells; antheridia contained in small cavities; tetraspores cruciate, arranged in moniliform filaments, which are packed together in external excrescences (nemathecia); cystocarps ex- 
ternal, globose, sessile or perlicellate, containing within a thick pericarp sereral irregular masses of spores imbediled among the cells of the froml ; spores dischargenl by a narrow carpostome.

The genus comprises right or nine speries of the North Atlantio and Mecliterranean, one speetes, $P$. Clemlandii, being foumd on the coast of california. The sprecies are dark resl, rather coarse and rigid, not allering to paper, and ure sery apt to loe coserel with lirgesm. They inhahit rather deep water, and are characterized ley their esternal fruit, the tetraspores being arranged in uemathecia or warts compused of densely pached tilaments, each coll of which heomes a cruciate tetra-pore. some of the lirualer forms pass with collectors fin species of lihedymenin.

\section{P. Brodrer, Ag.; Phye. Brit., Pl. 20.}

Stipes eylimbrieal at base, compressed upwards, branehed, the hranclues expanding into ohlong or wedge-shaped, simple or forkenl, memhranaceous laminie, often proliferous at the summit; eystocarps globose, sessile on the laminat nemathecia spherical, perlunculate, at the tips of the laminae.

In five to ten fathoms of water.

Newport, R. I.; Wood's Holl, Mass.; and common from Sahant northward.

P. membraxmolia, Ag.; Phyce. Brit., Pl. 16 ;.

Stipe cylinchical, filiform, branched, the branches expanding into broally wedge-shaped bifid or dichotomous laminat; cystocarps ovoid, stipitate, rising from the branches or laminat nemathecia forming hroad, dark-colored, convex patches in the center of the laminie.

In deep water on stones.

\section{Common from Longr Island Sound northward; North Atlantic.}

Our two speries of Phyllophora are perfectly easy to identify when tetraspurie specimens are obtained. I'. Brodini is a larger plant than $I$ '. membranifulia, and the laninat are longer and larger and less broad at the base than in $P$. membranifoliu. I'. Brodini varies consideraluly, howeser, and in the spring the hright-red loroal laminat are often liroken from the stipes and washed ashore, when they might be mistaken for sone species of Rhodymenia.

\section{GYMNOGONGRUS, Mart.}

(From rupus, naked, and yoy'pos, an excrescence.)

Fromls dark red or purple, carnoso-coriaceous, terete, compressed or flat, dichotomous, composed of a medullary stratum of roumdish, angrtlar, colorless cells and a cortical stratum of closely packed short filaments formed of small colored cells; tetraspores cruciate, borne in hemispherical nemathecia; cystocarps immersed in the swollen frombl, consisting of several irregular masses of spores imberleded among tho cells of the frond; spores discharged by a carpostome.

A genus of alout thing species found principally in the warmer parts of the world, all rather cortaceous, but not attaining any great size. The geuns is distingmisherd 
from Chondrus, to which several of the species were formerly referred, by the structure of the frond and the arrangement of the tetraspores; from Phyllophora by the absence of a stipe and the immersed eystocarps.

G. Norvegicus, J. Ag. (Sphcerococcus Norvegicus, Ag.-Chondrus Norvegicus, Lyngb. ; Phyc. Brit., Pl. 187._Oncotylus Norvegicus, Kiitz.)

Fronds deep red, two to four inches high, linear, dichotomous, flat, fastigiate, axils rounded, patent, apices obtuse; cystocarps immersed in the upper segments projecting on both sides of the frond; nemathecia sessile, hemispherical, on both sides of the frond.

In deep pools on rocks.

Penobscot Bay, Mr. Hooper; Peak's Island, Maine, W. G. F.; Nahant, W. G. F. ; Beverly, Mass., Miss Alexander. Europe.

Our plant, which is apparently rather rare, is the same as that of Europe, although narrower forms are sometimes seen which perhaps might be referred to the G. Torreyi of Agardh. G. Griffithsia is to be expected with us, as it is common in Europe. The present species is found only in the autumn and winter, either in deep cold pools or below low-water mark. Its resemblance to the simpler forms of Chondrus crispus is so great that it is perhaps mistaken for that species by ainateur collectors. Its color, however, is red rather than purple, and the whole plant is thinner and more delicate than C. crispus, which, moreover, has quite a difierent microscopic structure.

G. ToRreyi, Ag.

Frond compressed, flattish, dichotomous, fastigiate, segments linear, very narrow, the axils rounded.

\section{New York, Prof. Agardh.}

A species known only by the above description of Agardh. Bailey, in Am. Jour. Sci., Vol. VI, 1848, p. 39, makes the singular statement, in speaking of Dasya elegans, Ag., that he has examined a fragment of the original specimen of Sphcrococcus Torreyi in the Torrey Herbarium, "which," he says, "unless I am greatly mistaken, was founded on a battered specimen of this plant."

\section{AHNFELDTIA, Fries.}

(Named in honor of Nils Otto Ahnfeldt, of Lund.)

Fronds cartilagineo-corneous, subterete, dichotomous or irregularly branched, composed of densely packed elongated cells within and a horizontal layer of closely packed short filaments formed of small colored cells; cystocarps immersed in the fronds; tetraspores in nemathecia which surrounded the branches (?).

A small genus, comprising stiff, wiry, or cartilaginous algx, whose fructification is not well known. As it is, the genus is distinguished from Gymnogongrus rather by the rigiclity and terete character of the fronds than by any more definite character, since the fact that the tetraspores in the present genus are in the nemathecia which surround the brauches, even if fully proved, which is not the case, would hardly constitute sufficient ground for the separation of the genera. In the only common species of the North Atlantic cystocarps have never been seen and the nemathecia have not been satisfactorily examined. In Ahnfeldtia gigartinoides of the west coast the cystocarps form nodose swellings in the upper part of the branches, and there are numerous car- 
pustomes by which the spores are dischargol. IInwerer ill defined the present genus may be, there is no difficulty in recognizing at sight our only species.

A. PldeAta, Fries. (G!ymnogongrus plicutus, Kiitz.; I’hye. Brit., P’l. ¿ssi._-Gigartinu plicata. Lam.x.-Npharococenes plicutus, Ag.)

Frombs horny, terete, filiform, rery irregularly branched, entangled, branches di-trichotomous, with lateral, often secomd, branches, axils rommlenl, terminal divisions elongated; cystocarps and tetraspores?

Var. FAstigiata.

Fronds regularly dichotomous, terminal segments equal.

On rocks and algae in exposed tide-pools.

From New York nothward; Europe; North Pacific.

Forming very irregularly loranched, rigid tufts several inches in diameter. The color is usually nearly black, beeming on exposure yellowish or greenish. More wiry and rigid than any of our other Floridea.

\section{CYSTOCLONIUM, Küt.}

(From кvorts, a bladder, and $\kappa \lambda \omega v \iota 0 v$, a small twig.)

Fronds fleshy, succulent, terete, decompoundly branched, composed of three strata of cells, an axile series of loosely interlaced filaments formed of delicate elongated cells, surrounding which is a layer of large rounded cells and a cortical layer of small roundish-angular cells; antheridia in spots on the upper part of the fromds, interspersed among the unchanged cortical cells; tetraspores zonate, scattered in the cortical layer; cystocarps large, immersed in the frond, usually prominent at one side, with a single carpostome.

The account given above of the structure of the frond refers to the appearance presented in sectioning the mature plant. A study of the development shows that the external and medial layers really are derived from the axial filaments, or rather that all three are formed from a common set of filaments at the apex of the frond. The froml of Cystoclonium might be mistaken for that of Rhabdonia, lut the fruit is very diffierent. The genus comprises about half a dozen described species, but only one is at all well known.

C. Ptrpurascess, Kiitz. (Iypmea murpurascens. Harv., Phỵe. Brit., T'1. 116.)

Fromels hownish rose-colored, six inches to two feet long, an eighth to a quarter of an inch in diameter, terete, subpinnately decompound, much branched, branches alternate, elongate, heset with alternately decompound branchlets which taper at each end; egstocarps numerroms, large, often forming nodose swellings in the branches.

Var. CIRRHOSA.

The branches drawn out into long, twisted tendrils. 
In tide-pools and just below low-water mark.

Vers common from New York northward; Europe.

With the exception of Ceramium rubrum, the present is probably the most common species of Floridere found on our coast. It not unfrecpently attains a length of a foot and a half, and when washed from its attachment and exposed to the sunlight assumes a bright orange color, which is attractive to many collectors. The Solieria chordalis, said by Mr. Samuel Ashmeal* to have been collected in Greenland by the Hajes Arctic expeclition, was probably a sterile plant of Cystoclonium purpurascens.

GIGARTINA, Lam.x.

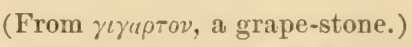

Fronds fleshy, cartilaginous, compressed, composed of an internal layer of longitudinal, slender, anastomosing filaments, which pass horizontally outwards and divide dichotomously into short moniliform fila. ments, the whole set in a gelatinous substance; antheridia in superficial spots; tetraspores cruciate, densely aggregated, forming spots just below the surface; conceptacles external.

A genus of which nearly fifty species have been lescribed, but some of which are of doubtful value. They abound in the Pacific Ocean, several species being found in California, but we have only one species.

G. mamillosa, Ag.; Phyc. Brit., Pl. 199.

Fronds dark purple, three to six inches high, half an inch to two inches broad, flattish, channelled, linear, decompound, dichotomous, fastigiate, upper segments redge-shaped, bifid; cystocarps borne in short papillæ given off from the surface and margin of the frond.

On rocks at low-water mark, in company with Chondrus crispus.

Common from Boston northward; Europe.

Bearing some resemblance to the common Irish moss, with which it usually grows, but distinguished by the numerous papilla which cover the surface of the fronds and bear the fruit. The present species may occur in California, but most of the specimens of G. mamillosa from the west coast belong rather to G. papillata, Ag.

\section{CHONDRUS, Stack.}

(From $\chi 0 \nu \delta \rho \circ$, cartilage.)

Fronds and tetraspores as in Gigartina; cystocarps immersed in the frond.

A small genus as limited by modern writers, but formerly made to include a large number of forms. The three genera Gigartina, Chondrus, and Iridec are very nearly related. In the first-named genus the cystocarps are borne in external conceptacles, and in the last two they are immersed.

C. Crispus (Linn.), Stack.; Phyc. Brit., Pl. 63.-Irish moss.

Fronds purple, three to six inches high, stipitate, flabelliform, dichotomous, fastigiate, flat, the segments linear-cuneate; cjstocarps immersed in the frond and usually projecting on one side. 
On rocks at low-water mark.

Common from New York northward.

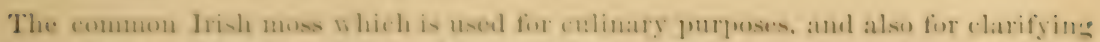

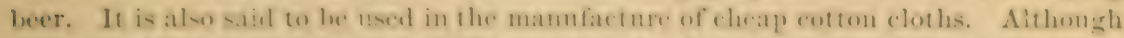
very variahle in shape, it is not likely to lo mistahen fer any other species, escept

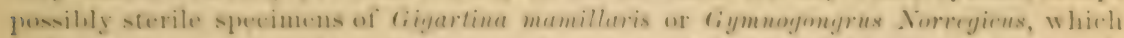
is, howerer, a rare species. When growing exposed to the light, the collor is a sellow-green.

\section{Suborder RIIOTMMENIEA.}

Fromels memluanaceons or filiform, solid or tubular; antleridia formeing superficial patches: tetraspores tripartite, cruciate, or zonate, either sattered in distinct spots or sometimes smok in rerpts; cystocarps external, containing densely packed subdichotomous filaments, arranged in distinct masses aromme a basal placenta with a thick pericarp, which is comnerted ly mumerous filaments with the placenta.

The present suborder is exceedingly ill-elefined, and no two writers agree exactly as to its limts. In the typieal genera we find a distinct basal placenta on which are lorme mases of spores, which when young are seen to be formed of sublichotomous filauruts, but which when mature are arranged without order and held together by a grelatinous curelope. Diverging from the type, we have genera like Cordylecludia, in which, even at maturity, the spores preserve to a certain extent a moniliform arrangement, and we then have a eysterarp lut little different from that of Gracilaria, which belones to the splue rococevider. On the other hand, we have the order connected with the Cryptonemied by Clrysymenia, which is now placed by Agardh in the lihodymeniacer.

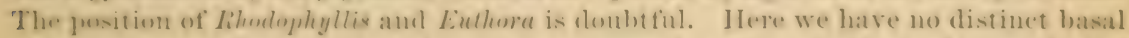
flawenta, hut rather a central placenta or carpogende cell, reminding one some what of the genus lihaludenia and its allies, which have heen included in the Solieriea. Euthora, at any rate, demands a mere accurate stuly, and our own species of lihodophyllis, $I$. efprewla, dies not well corre-pond with the typical members of the suborder in relation to its eystocarpie fruit. Lomentaria and Champia agree with the Fhodymenird in the-ir frnit, althengh the fromb are preeuliar, and we hare kejt them as a division of the present.

Tribe I. RHodvaenie e proper.

Cystocarps with a basal placenta, fronds solid.

Fromls dichotomous or palmate.................. Rhodymenia. Fronds pinnately compound ...................... I'locamium. Fronds filiform.................................. Cordylecladia.

\section{? Tribe II. RHodopHyLles.}

Oystocarps with a central placenta, fronds membranaceous.

Tetraspores zonite, fromisilichotomous or pinnate........ lihodophyllis. Tetraspores cruciate, fronds dentato-pinnate............. Euthora.

\section{Tribe III. LOMENTARIEA.}

Cystocarps with a basal placenta, fronds tubular.

Fronds eonstricted at the joints, but with no proper diaphragms, tetraspores sunk in depressions of the frond................ Lomentaria. Fronds with numerous diaphragms, tetraspores superficial.... Champia. 


\section{RHODYMENIA, (Grer.) J. Ag.}

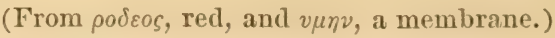

Fronds flat, membranaceous, dichotomous or palmate, composed of an internal layer of large roundish-angular cells and a cortical layer of smaller cells, in some cases arranged in short horizontal filaments; tetraspores cruciate, either collected in superficial spots (sori) or seattered in the cortex; cystocarps external, sessile, with a distinct carpostome, spores irregularly grouped in masses attached to a basal placenta and surrounded by a gelatinous envelope.

A genus which formerly was made to include a large number of flat membranons species, a large part of which have hy recent writers been removed to other genera. We have but one species on our coast, Rhodymenia palinata, the common dulse, of which, unfortmately, the crstocarpic finit is unknorm, and the sturly of the fruit of the genus is out of the question with us.

R. Palinata, (Linn.) Grev.; Phyc. Brit., Pls. 217, 218; Aun. Sei. Nat., Vol. III, Ser. 4, Pl. 3, Fig. 8.-Dulse.

Fronds purplish red, broadly redge-shaped, six to twelve inches long and four to eight inches broad, irregularly cleft, palmate or dichotomous, sometimes repeatedly laciniate, the margin often winged with leaflets; tetraspores cruciate, scattered in patches orer the frond, immersed in the cortex; cystocarps?

Var. SARNIENSIS.

Divisions very numerous, narrow, sublinear.

On Fuci, Laminario, and other algre, between tide-marks, and extending into deep water.

Common from New York northward; North Atlantic; California?

This, with Chondrus crispus, forms the only species eaten in New England. The present species, althongh one of the commonest red sea-meeds in the North Atlantic, has never been known to bear cystocarps, and hence the generic position is doubtful. The description given applies to the typical form, and although the fronds are very rariable in outline, the species is easily recognized. It is sold in the seaport towns, where it is to be found dried on the fruit-stands of the women who sell green apples, corn-balls, and other dainties. It is said to possess anthelmintic properties, which, if one can judge by its disagreeable taste, is very probable.

\section{PLOCAMIUM, Lyngb.}

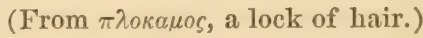

Fronds compressed, membranaceous, pinnately decompound, the pinnules alternately secund in twos, threes, fours, or fires, composed of an inner layer of longitudinal, oblong cells and a cortical layer of smaller polygonal cells; tetraspores zonate borne in special branchlets; cysto- 
carps extermal, sessile or pedicellate, with a distimet carpostome, spores in several masses composed of elosely parked ratiating filaments lorme. on a basal placenta.

A loeautiful gemus, comploising alout twenty-five species, the most striking of which are found in Anstralia, New Zealand, and at the Cape of thend Hepre. I'. concrineum is very widely diffused in the .orth Atlantic and Paeifie, and possibly also in the sonthern hemisplere : lont it has only been elserved onee on the coast of New England,

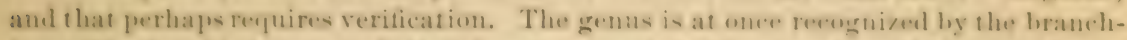
me. The froml is linear and distichously pimnated, the pinnules, which are always alternately secumel in groups of from twe to tive. lecing of two kinds; the lowest pinua is short, simple, and acute, while the remaining pinna are pimmlate or pertinato-decompenul. The eystocarps of Plocemium are similar to those of lihoulymeniu,

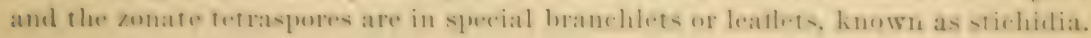

P. Coccinetar, Lyugb.; Phyc. Brit., Pl. 44.

Fronds narrowly linear, without a midrih, decompunum pinnate, pinna alternately secumb in threes or fours, the lowest subulate and entire, the upper peetinate on the upper side; conceptacles marginal, solitary, sessile; tetraspores zonate on divaricately branching processes borne on the inner side of the pectinated branchlets.

\section{Boston Bay, Miss Hazkshurst.}

The above-named locility, griren in the Nereis, is the anly one known on the New FinGlaml mast, for this widely diffised speecies, if we except the vagne statement of liailey in the Ameriean Journal of seience, Vol. III, 1=47, p. st, that it has heen found ley Rie.

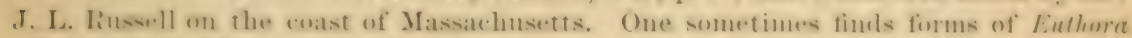
eristuta labellet $P$. corrimem in American herbaria. The common Califurnian form ot

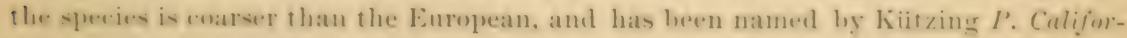
nicum. It is not, however, distinct.

\section{CORDYLECLADIA, J. Ag.}

(From $\kappa \circ \rho \delta \lambda \eta$, a club, and $\kappa \lambda a \delta o s$, a branch.)

Fronds filiform, irregularly branched, carnoso-cartilaginous, formed of two strata of cells; medullary layer of oblong, longitudinal cells, cortical of roundish, colored, subseriated, rertical, minute cells; conceptacles sessile on the branches, sulsspherical, furnished with at cellular pericarp at length perforate, containing a densely packed globular mass of roumlish angular spores, formed by the evolution of much-branched filaments issuing from a basal placenta; tetraspores immersed in the periphery of pod-like ramuli, oblong. cruciately partecl.

9 C. Hexti, Harv.

"Fromls densely tufted, springing from a common, expanded, crustlike disk, livid purple, tereti-compressed, once or twice forked or secundly branched; branches subulate, alteruate, acute; fruit?" (Ner. Am. Bor., Part II, p. 155.)

Narragansett Bay, Mr. George Bunt. 
A species only known from the description in the Nereis, which is quoted above, and from the specimen in Herb. Harvey for an examination of which we are indebted to Prof. E. Perceval Wright. In the absence of fruit, the genus must remain in doulst, and it is hardly likely that the species, as described by Harvey, will be again recognized by American algologists.

\section{RHODOPHYLLIS, Kiitz.}

(From $\rho 0:$ Sov, a rose, and $\phi v \lambda \lambda o v$, a leaf.)

Fronds membranous, dichotomously compound, with proliferous or pinnatifid margins, composed of an internal layer of large roundishangular cells aud a cortical layer of smaller cells ; tetraspores zonate, immersed in the cortex of the frond or marginal processes; cystocarps external, subspherical, borne usually on the margin of the frond or on lateral processes, spores arranged around a central earpogenic cell in masses composed of densely packed radiating filaments, whose cells at maturity become irregularly placed.

A genus comprising about twenty species, which mostly inhabit the Australian coast. They have membranously expanded fronds resembling those of the genus Rhodymenia, but they are as a rule smaller and thinner, the internal layer consisting of usually two series of cells. The genus is distinguished from Rhodymenia by the zonate tetraspores, aud by having the carpogenic cell or placenta in the center of the conceptacle instead of at its base. In the typical species of Kiitzing, $R$. bifida, there is, according to Dr. Bornet, a large carpogenic cell at the center of the conceptacle, around which the sporiferous masses are gathered, and the same is true with regard to our own Rhodophyllis veprecula.

R. veprecula, J. Ag. (Ciliaria fusca, Rupr.-R. veprecula and Calliblepharis cilista, Harv., Ner. Am. Bor., Part II, Pp. 105, 152, non Calliblepharis ciliata, Kiitz.)

Fronds deep red, attached by a branching base, two to five inches long, a quarter of an inch to an inch and a half broad, decompoundly dichotomous, margin pinnate, pinnæ linear-lanceolate, ciliate, with short subulate or forked teeth; tetraspores zonate, borne in the cortex of the cilia; crstocarps subglobose, usually borne at the base of the cilia, often densely aggregater, sometimes borne on the surface of frond.

Var. cirrhata, Harv.

Fronds very narrow, dichotomous, the apices cirrhiform, repeatedly forked.

On the larger algae in five to ten fathoms, and rarely in deep tidepools. Autumn and winter.

Campobello Island, Grand Menan, Maine, Prof. Eaton; Gloucester, Mass., W. G. F.; Arctic Ocean.

The present species is a characteristic Arctic form which occurs as far south as Cape Ann, where it is not rare although hardly common. It is usually found washed ashore late in the autumm or in winter. It is recognized by its beautiful red color and frond 
destime of a milrito and with a eiliated margin. It hears a close resemblanee fo calliblepharis ciluate, kible, which is a rommen kuropean speries, and it was introclucenl muler that name in the Xereis, in which work lihodephlyllis crprecula was cited on the antherity of Agarilh. But suberguent ohsersation and examination of the egstocarpic

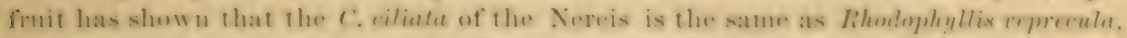

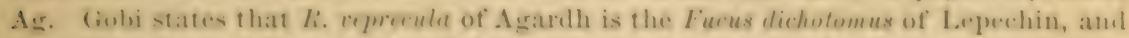

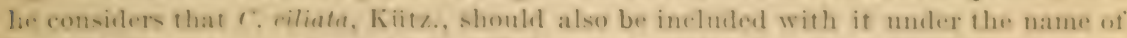
Lihedephyllis die hatoma (Leperehin). We have retained the name of Agardh beratse we

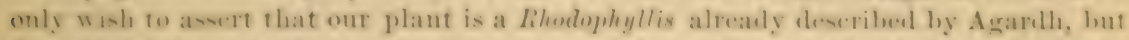

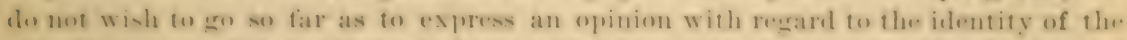
two kumpan plants, since we have never leen ahle to examine the fruit of $r$.

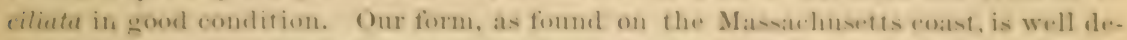

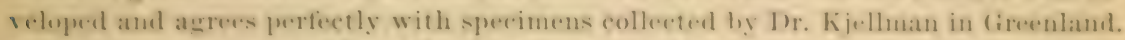
The narrow variety was found by Harvey at Halifax. In Herh. Gray is a narrow specimen from Lalorator, marked calliblepheris jubete, apparently in Lenormands Laud writing.

\section{EUTHORA, $\Lambda \mathrm{g}$.}

\section{(Derivation uncertain.)}

Frouds membranaceous, subulichotomously pinnate, formed internally of large oblong cells, between which is a network of slender branching filaments with a cortical layer of small cells; tetraspores cruciate, im. mersed in the cortex of the thickened apices: cystocarps external, sull. spherical, marginal, containing a central nuelens attacheel to the walls of the conceptacle composed of tufts of radiating sporiferous filaments around an ill-defined cellular placenta.

A small gemus of only two species, one of whieli is fomml in the North Atlantic and

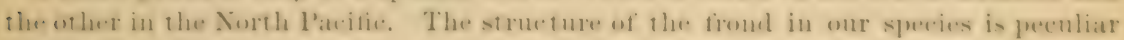
ame is the same as that of the gremes collophyllix. Between the rather large cells of the interior run small loranelung filanents, best seen in longitudinal sections. The grenus is separated from lihedymenia, in whiels it was formerly included, in consepuence of the pectuliar froml and cystmarp. The structure of the latter is unt at all well howw and shonld be stmolied on our coast, where there is an abundance of naterial. The conceptarles are suall and are borne on the margin of the fromd, and the carportwme is not at all prominent. The arrangement of the spores is eomplieated and not easily described. They are arranger in tufts of short filaments, radiatiug fiom a counmon proint, and the different ufts, which are very numerons, apparently surround a central cellular placenta, not at all sharply defined. At any rate, there is no large carpogrenic cell, reither at the center, as in lihodonhyllis, or at the base, as in lihodymenia, and it is ly un mans certain that the genus slowla he placed in the present suborder.

E. cristata, J. Ag. (Apharococeus cristatus, C. Ag.-Rhorlymenia cristutu, Girev.; Phye. Ririt., Pl. 307.-Callophyllis rristatn, Kiitz.)

Fonds rosy-red, one to five inches high, membranaceous, flabellately expanded, main dirisions widely spreading. alternate, repeatedly sub. divided, upper divisions altermate, linear, laciniate at the tips, with a fimbriated margin; tetraspores cruciate, in the thielienecl tips of the frond; cystocarps small, marginal, nearly spherieal.

On alrix, especially on Laminaria, in deep water. 


\section{Staten Island ; Newport, R. I., Bailey; dredged off Napatree Point,} R. I., Prof. Eaton; Gay Head, in eight or ten fathoms; and common from Nahant northward.

Together with Delesseria sinuosa, this species forms the bulk of the membranaceous red sea-weeds collected by ladies on our northern coast for ornamental purposes. Probable in no part of the world are more beautiful and luxuriant specimens found than at Magnolia Core, Gloncester, Mass. Specimens vary very much in breadth. Some have the main divisions an inch wide and the terminal divisions are densely Habellate. Others are scarcely an eight of an inch wide and the terminal divisions are rather diffuse, the fimbriatious being prolonged into sharp teeth. The first-mentioned form approaches the figure in the Phycologia Britamnica, while the last resembles Spherococcus coronopifolius. The Loug Island forms are searcels an inch high. The species is found at all seasons of the year, and inhabits rather deep water, its farorite habitat being the roots of Laminarice.

\section{LOMENTARIA, (Gaill.) Thuret.}

(From lomentum, a pod with constricted joints.)

Fronds filamentous, branching, hollow, with coustricted nodes, formed of one or more layers of roundish-angular cells with a few longitudinal filaments in the interior; tetraspores tripartite, borne in cavities formed by the infolding of the cortex; cystocarps external, sessile, containing a nucleus composed of oblong masses of irregularly radiating spores attached to a placenta surrounding a large basal carpogenic cell, which is connected with the pericarp by filaments.

A sinall geuns, containing species which have been placed by some writers in chylocladia and Chrysymenia. As limited by Thuret, the gemus includes species in which the tetraspores occupy small cavities hollowed out in the cortex. The development of the fronds has not been fully studied. They are hollow and much constricted at the joints, but in our species there are no distinct diaphragms as in Champia. The walls of the filaments are composed of a membrane consisting of a single layer of roundish-angular cells, or there are two or three lavers, the onter cells being smaller than the rest. The inmer side of the wall is traversed by long, slender filaments, to which are attached, lateralls, small round cells, by which the filaments are attached to the walls. The cystocarps are external, and, in section, one sees a large basal triangularoroid carpogenic cell surrounded by closely packed sporiferous lobes, in which the cells are at first arranged in the form of densely radiating filaments, but at the time of maturity become irregularly placed. The pericarp is rather broadly ovate, with a distinct terminal carpostome, and its walls are connected with the carpogenic cell by filaments, between the bases of which lie the sporiferous masses, around which is a gelatinous envelope.

L. cxcinat ג, Menegh., in J. Ag., Spec. (Chylocladia Baileyana, Harr., Yer. Am. Bor., Part II, p. 185, Pl. 20 c.-Chylocladia uncinata, Ag., Zan. Icon. Adr., Pl. 43.-Chondrosiphon uncinatus, Kiitz.)

Fronds bromnish red, densely tufted, two to five inches high, tubular, irregularly much branched, branches about one-tenth of an inch in diameter, divaricated, secund or scattered, often recurred, branchlets narrowly fusiform, much contracted at base, secund; tetraspores tripartite 
in cavities on the branchlets; cystocarps sessile on the branches, oroid, with a distinet terminal carpostome.

Var. FILIFonMis, IIarv., l. c.

slemler, clongate, with longer and less arehing branches.

On wharres, sponges, se., helow low-water mark.

Quiney, Matsi, Marrey: commen from Cape Cod southwart.

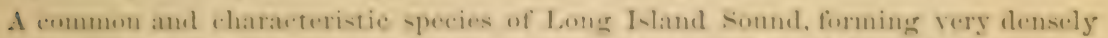

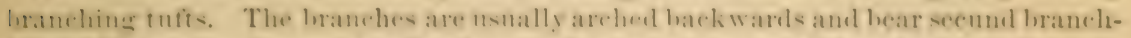
fers wheh are mueh constricted at hase. The arrangenent of the tetraspores in eavi-

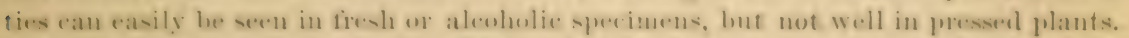

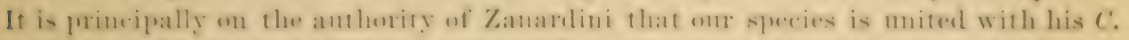
uncimente and as he hat plenty of matrerial for comparison his opinion is probaloly cor-

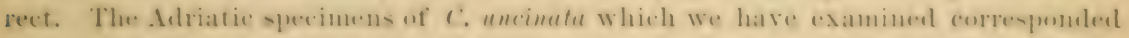
leiter with the rar, filifurmis than w ith the more common secumb torm of Long Inland Sounel.

L. Rosic.. (Harr.) Thuret. (Chrysymen iu rosec, IIarr., Plhye. Rrit., I'l. 358 a.-Chylocludin iosen, Harv., Yer. Am. Bor., Part II, 1) 186.)

Fromls rose-colored, compressed, hollow, triangular in outline, main divisions simple or once or twice forked, one and a half to three inches long, an eighth to a ynarter of an inch broad, tapering at the apes, pinnate with simple or pinnate, opposite, distichous branchlets, which are much contracterl at the base ; tetraspores tripartite, sunk in eavities in the cortex of branches.

On stones and shells in ten fathoms.

Portsmouth, X. H.; Yewport, R. I., Iturtey; Gay Head, II. G. F.; Sorthern Europe.

A rare and leatutiful species easily distinguished from the last ly leeing lorouler and flattened, with beatutiflly regular, opposite, distichous pinne. As far as we know, the eystocarpie fimit of this sque ies has never been seen. It is toleraloly abumbant on shells of Mytilus, in company with scinain furcellata, off Gay Head.

\section{CIIAMPIA.}

(In houor of M. Deschamps, a French botanist.)

Fromls filamentous, branching, hollow, nodose, formed of one or more layers of roundish-angular cells with cellular diaphragms at the nodes, traversed internally by a few longitulinal filaments ; tetraspores tripartite, scattered in the cortex; cystocarps as in Lomentaria.

A small gemu- complising alunt a duzen spereies, most of which are tropical or Anstralian, our - precies, C. parculu, being the most widely diffised. The geruus resembles

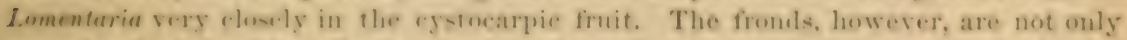

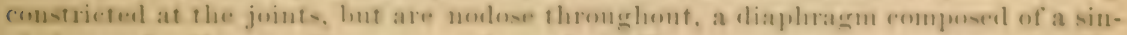

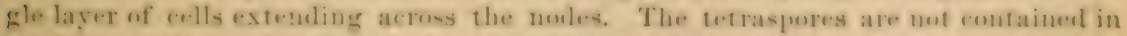
sunken cavities as in Lomenterin. A sertion of the erstorarpe of C parrula aud $L$. upcineta shews the stume arrangrment of the sprese, but in the firmt-named species

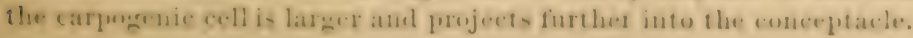


C. PARvula, (Ag.) Harr. (Chylocladia parvula, Phỵe. Brit., Pl. 210.Champia parvula, Ner. Am. Bor., Part II, p. 76.) Pl. XV, Figs. 2, 5.

Fronds brownish red, globosely tufted, two to four inches high, intricately branching, branches opposite, alternate, or whorled, nodose, joints once or twice as long as broad, apices obtuse; tetraspores tripartite, scattered in the cortex; conceptacles seattered, sessile, oroid, with a distinct carpostome.

On Zostera and algæ below low-water mark.

Common from Cape Cod southward; Europe; Pacific Ocean.

A homely species, which does not collapse when removed from the water. The conceptacles are larger than in our species of Lomentaria, and better adapted for the study of the arrangement of the spores.

\section{SUborder HYPNEA.}

Fronds filiform or subcompressed, branching; tetraspores zonate; c5stocarps external or partly immersed, filled with a spongy cellular mass, in which the spores are borne in small, scattered tufts on a branching filamentous placenta.

A small suborder, in which the crstocarpic fruit is peculiar. Sections of the crstocarps show a loose cellular structure which fills the interior, and scattered through the mass are small tufts of spores which remind one of the eystocarps of the Gigartinea. In the present instance, however, the spores are not arranged irregularly in globose groups, but they are attached to filanents which branch among the general cellular mass which fills the conceptacle. In the Notes Algologignes an account of the derelopment of the fruit in $H$. musciformis is given by Bornet.

\section{HYPNEA, Lam.x.}

(From Hypnum, a genus of mosses.)

Frouds filiform, virgately or divaricately branched, with subulate branchlets, composed of an internal layer of large roundish-angular cells, which become smaller outwards, and a cortex of small, colored, polygonal cells; tetraspores zonate, borne in swollen branchlets ; cystocarps external, subglobose, borne on the branchlets, containing a placenta composed of filaments which form a network, to which are attached at intervals tufts of spores.

A genus of about twentr-five or thirty species, most of which are tropical and rather ill-definerl, since the sterile aud fertile plants of the same species vary considerably in aspect. Most of the species have the tips of the branches swollen and rolled inwarls. The erstocarps are peculiar, and in sections one sees small tufts of pyriform spores, scattered through a mearly solid tissue composed partly of a network of branching filaments which form a sort of placenta and partly of the cells of the frond itself.

\section{H. MUSCIFORMis, Lam.x.}

Fronds filiform, purplish red, tufted, virgately branched, six to trelve 
inclies long, branches elongated, irregularly placed, clothed below with numerous, short, subulate branchlets, thickened and nearly naked near the apex, which is often much incurved; tetraspores zonite, borne in somer hat swollen branchlets ; eystocarps subghbose, mumerous, on divaricately branched spinescent branchlets.

New Bedford, Mass., Hurrey; Woollis Iloll, Wr. G. F; Orient, L. I., Iriss Booth; and southward to the West Indies.

\section{In four or five fathoms of water.}

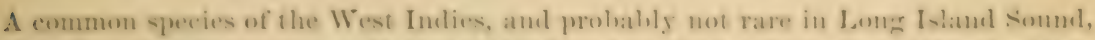

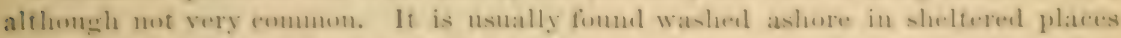

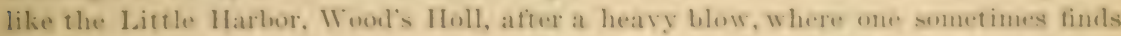
intricately twisted tufts two fiet in diameter. With useystocarps have mot heen seen,

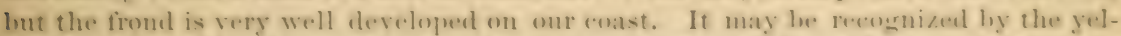
lowish-purple eolor, ly the lone hranches coverea! with short, subulate loramehleis, and espereially hy the swollen, naked apiees, which are rolled strongly inwards or almost circinate. Fertilespereimens from the West Indies are more robust and do unt so fre-

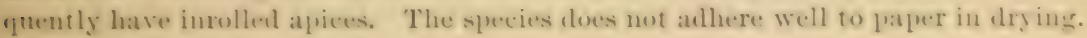

\section{Suborder GELIDIE.E.}

Fronds of a dense cartilaginous structure, filiform or compressed, branching; antheridia in superficial patches; tetraspores cruciate, borne in the cortical layer; cystocarps formed in swollen branches and composed of spores arranged singly or in short filaments on the surfice of an axile or parictal placenta, carpostomes present, often two in number;

Rather a small orler of dark-colored, rigid sea-weeds, whose frombls are formend of densely packed cells, and whose eystenearps are horn in swollen terminal hranches. but are not strictly external. In Gelidium the spores are sessile on an axile placenta, and there are two carpostomes on the opposite surfaces of the fromels. In I'terocludic the placenta is attanehed to the lateral wall of the eystocarp, the spores are lorme few in a row, and there is but one carpostome.

\section{GELIDIUM, Lam.x.}

(From gelu, frost, and, secondarily, gelatine.)

Fronds cartilaginous, terete or compressed, decompound-pinnate, formed of long eylindrical cells in the axis, surrounded by roundish cells which become small and polygonal at the surface; antheridia in superficial patches; tetraspores cruciate, seattered in the cortex; cystocarps immersed in swollen luranchlets, containing oblong or pyriform spores borne on an axile placentat which is attached by filaments to the walls of the cystocarp; carpostomes usually one on each side of the frond.

A genns of narrow ly linear or mearly terete algar of a clense structure, found in nearly all parts of the worlal. The limits of the slewirs are not well mathed, lecanse the ranifirations on whieh the priucipal specifie distinetions depend are very variable. The genus is recognized on our eoast ly the peculiar esstocarpes, which are formed in 
small branchlets, which become swollen and usua!ly have an opening on each side for the escape of the spores. A longitudinal section shows an axile placenta which passes through the cystocarp, on which the spores are borne, not in chains but singly. Numerous filaments connect the placenta with the wall of the esstocarp. The account given above of the frond applies merely to what one sees in sections of the mature branches. A section of the younger portions shows that there is originally an axile filament, from which are given off other filaments which are nearly parallel to the axis, and which afterwards turn outwards and form the cortical layer, the cells of which they are composed becoming rounder and short. The genus differs from Pterocladia merely in the position of the placenta, which in the last-named geuus is not central, but is attached laterally to the wall of the cystocarp.

G. CRIxAlE, J. Ag., Epier. (Gelidium corneum, var. crinale, auct.Acrocarpus lubricus and crinalis, Kiitz., Tab. Phyc., Tol. XVII, Pls. 32, 33.)

Fronds caspitose, dark purple, setaceous, one to three inches high, primary axis procumbent, from which arise erect, subterete, once or twice pinnate branches, pinnæ distichous, alternate, short, patent, acute, often pinnatifid; tetraspores cruciate, borne in thickened subspathulate or pinnatifid apices.

Forming tufts on mud-covered rocks and stones at low-water mark.

Portland, Maine; Red Hook, N. Y., Harrey; New Haven; Wood's Holl, W. G. F.; Malden, Mass., Mr. Collins ; Europe; California.

We have followed Agardh in separating the var. crinale from the polymorphic and very widely diffused G. corneum. The typical form of the latter occurs in Florida and on our west coast. G. crinale has been as yet recorded in but few localities, but it is probably common along our whole coast. It is a homely, insignificant species, usually not much thicker than a bristle, and forms small blackish patches on mud-covered rocks.

\section{Suborder SOLIERIEA.}

Fronds filiform or compressed; tetraspores cruciate or zonate; cystocarps immersed in the frond, usually prominent at one side, spores arranged in short filaments and arranged in tufts around a large central carpogenic cell or a central placenta, which is attached to the wall of cystocarp by filaments; carpostome distinct.

A small suborder, of which we have but a single species. It is characterized by having the spores produced few in a row and attached either, as in Solieria and Eucheuma, to a large central cell, or, as in Rhabdonia, to a large cellular placenta at the center of the cystocarp. Whether Rhabdonia should be united in a suborder with Solieria is perhaps doubtful. By some the genus is considered to be related to the Rhodymeniea, and its affinity to Rhodophyllis and perhaps Euthora is not remote.

RHABDONIA, Harv.

(From $\rho a \beta \delta o s$, a wand.)

Fronds deep red, cyliudrical or nodose, branching, formed of an axis composed of slender, branching, longitudinal filaments surrounded by 
a layer of large roundish-angular cells and a cortical layer of smaller cells; tetraspores zonate, scattered, immersed in the cortex; cystoearps immersed in the froml, and projecting at one side, opening by a distinct carpostome, inclosing tufts of spores arranged in short, dense filaments, surrounding a globose, cellnlar, central placenta, connected by filamentous bands with a plexus of the axial filaments which surrounds the sporiferous mass.

A genus comprising from fiften to twenty species, the greater part of which are confined to Anstralia, divided by Arardh into two sulgenera, in one of which the fromd is erlindrical and in the other constricted at intervals. Our speecies belongs to the first division, and the frond resembles closely that of Cystorlonium purpuruscens, and the same is true of the tetraspores. The eystocarps are large, and project on one sirle. The genus is placed by Agarilh near Solieria, but in that genus the spores are placed around a very large eentral carpogenie cell, while in lihabdonia they are attacherd to a larire, solicl, central placenta formed of cells. The placenta is attached to the walls of the eystocarl, by numerous bands of interwoven filaments, between which are the sporiferous masses, which consist at maturity of short filaments, whose cells are changed into spores, which are not held together ly a gelatinous envelope as in Champia.

1. texena, Ag. (Gigartina tenera, J. Ag., Symb.-Solieria chordalis, IIarv. (non Ag.), Yer. Am. Bor., Part II, p. 121, Pl. 23 a.-Thabdonia tenera, J. Ag., Spec.-R. Baileyi, Harr. MISS., Am. Journ. Science, Vol. VI, p. 39.) Pl. XIV, Fig. 2.

Fronds deep red, from six inches to a foot and a half long, eylindrical, attached by a small disk, simple below, above densely branched, alternately decompound, branches long, virgate, erect, tapering at the base and apex, and furnished with numerous, linear, fusiform branchlets; tetraspores zonate, scattered in the cortex; cystocarps numerous, immersed, but projecting at one side.

In warm, quiet bays, in shallow water.

Common from Cape Cod southward ; Goose Core, Gloncester, Mass., W. G.F.

A characteristie species of Long Island Sound, and only known in one loealify north of Cape Corl, but extending southward to the West Indies. It forms beautiful tufts often two feet long. in muddy places around wharves and in sheltered places, and is not likely to be mistaken for any other plant, except possibly for a large form of Cystoclonium purpuraseens. The procarps consist of three cells, and from the innermost or that nearest the axis grows a long trichogyne, which curves round in a tortuons fashiou, and makes its way to the surface, reminding one of the trichogynes of Halymenin ligulata, figureal by Bormet. The section of the cystocarp given ly Harrey in the Nereis dies not pass through the center, and the crstocarp is not a closed carity, an supposed by Harvey, hut has a distimet rarpostome: nor are the spores pyriform and attached to separate perliewls, but they are formed from the cells of short filaments. 


\section{Suborder SPONGIÓCARPEA.}

Fronds solid, cylindrical, branching; antheridia in spots on upper part of fronds ; tetraspores cruciate, immersed in the cortical filaments; cystocarps in external wart-like protuberances, composed of parallel filaments, spores oborate, densely packed around the surface of a cellular mass which surrounds the tip of a short pedicel.

The present suborder was made by J. G. Agardh and Harrey to include a single species, I'olyides rotundus, a species in severạl respects anomalous. The development of the cystocarps of that species was first made out by Thuret and Bornet, and a detailed account was published in the Études Phycologiques. In its development the cystocarp of Polyides resembles that of the genus IJudiesnaya. There is produced from the cells at the base of the trichogrne a number of filameuts which wind amongst the short filaments, of which the wart-like bodies near the tips of the fronds are formed. These filaments come in contact with certain cells of the protuberances, which then divide and produce the spores. Although this indirect fertilization of the carpogenic cells by means of windiug filaments is the sane as is found in Dudresnaya, the mature cystocarp is different in the two genera. In Polyides the ripe spores are arranger in a regular layer around a small placenta, which is borne on a short pedicel produced from the carpogenic cell. In Dudresnaya coccinea the spores are irregularly grouped around a placenta surrounding the carpogenic cell itself. In D. purpurifera, howerer, according to D. Bornet, the cristocarps more nearly resemble those of Polyides, and he thinks it not impossible to unite the two genera in one suborder.

POLYIDES, Ag.

(From $\pi 0 \lambda v s$, many, and $\iota \delta \varepsilon a$, form.)

Fronds cylindrical, dichotomous, composed of interlaced branching filaments, consisting of elongated cells and curring outwards at the surface so as to form a cortical layer of horizontal filaments; antheridia in patches on the upper part of frond, consisting of short, densely packed filaments bearing clusters of antherozoids; tetraspores cruciate, immersed in the cortical layer; cystocarps in wart-like protuberances on the upper part of the frond.

P. Rotundus, Grev.; Phye. Brit., Pl. 95.

Fronds blackish red, cylindrical, eartilaginous, three to six inches long, attached by a disk, with an undivided stipe, which becomes above repeatedly dichotomous, apices obtuse; warts flesh-colored, numerous on the upper divisions of the frond.

On stones in deep pools and in deep water.

Common from New York northward; Europe.

A species easily recognized by its regularly dichotomous, eylindrical frond, by its dark, almost black, color, and dense cartilaginous substance. When sterile it might be mistaken for Furcellaria fastigiata, a common species of Northern Europe, which may be expected to occur on our coast. In fruit, however, they are easily distinguished, since the cystocarps of Polyides are borne in external warts, while those of Furcellaria 
are in the somewhat swollen tips of the formel. The present spereies is usually fommd

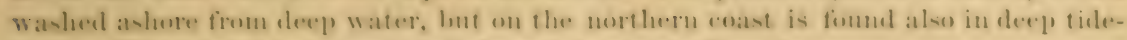
perels. When dried it beromes britule and does not adlere to paper.

\section{SUBORER SPHAROCOCCOHDEA.}

Fronds eylimbrieal or membranaceous, sulstance often very delicate; antheridia forming superficial patehes or occasionally contained in sunken eavities; tetraspores aruciate, zonate, or tripartite, often collected in spots (sori) on the surfice; eystocarpss external, hemisplerical or flask-shaped, spores arranged in moniliform filaments, which radiate from a basal placenta, carpostome distinct.

The present sulorder is by Agardh and some other writers divided into fwo, thes spharococemided, which include rather coarse cartilaginous algat, which are cylindrical or somewhat compressed, but hardly memhranaceous, and the lhelesserien, which ares rosy-red and of delieate texture and clistinetly membranaceons. The fruit, however, is very similar in both groups. The spores are arranged in subliehotomous filaments, which racliate from a hasal placenta, which in some grenera, as cirucilaria, projects far into the cavity of the cystocarp. The suborder differs from the Lihodymenien in that the moniliform arrangement of the sporiferous filaments is preserved even at maturity, and the filaments are distinct from one another and not held together by a gelatinous envelope. It must, however, be admitted that there are grenera which seem to indicate a close relation between the two suborders.

\section{GRINNELLIA, Harv.}

(Named in honor of Mr. Henry Grinnell, of New York.)

Fronds rosy-red, occasionally purple, delicately membranaceous, with a slender percurrent midrib, composed of a single layer, at the midrib of several layers, of large polygonal cells; antheridia in tufts on both sides of the frond; tetraspores tripartite, in swollen spots on the frond; cystocarps sessile on the frond, flask-shaped, spores in dichotomously branching filaments arising from a basal placenta.

A genus comprising a single speeies, which is found from Cape Cool to Norfolk, separated from Delexseriu hecause the tetraspores are formed in incrassated spots on the froml. The genus is too near Delesseria, of which it should perhaps form a sulugenus.

G. Americaxa, IIarv, Ner. Am. Bor., Part II, Pl. 21 \%. (Telesseria Americana, Ag.-Aglaiophyllum Americanum, Mont.-Cryptopleura Americana, Kiitz.) Pl. XIII, Figs. 2-4.

Exs.-Alg. Am. Bor., Farlow, Anderson of Eaton, Xo. 64.

Fronds dicreious, four inches to a foot and a half long, one to four inches widle, lanceolate, tapering at the extremities, oceasionally bifid or proliferous, margin smooth or wary; antheridia in small spots on both sides of the frond; tetraspores scattered orer the frond in thickened spots; eystocarps scattered, sessile, flask-shaped. 
On wharves, shells, stones, and sponges below low-water mark, and extending to several fathoms.

Cape Cod, southward.

This, with the exception perhaps of Dasya clegans, is the most beautiful alga of Long Island Sound. It is often found in tufts on wharves below low-water mark, and it flourishes in rather warm, shallow bays. It is met with at all seasons of the year; and, according to Miss Fisher, of Edgartown, the ladies of Martha's Vineyard collect it in winter, when it is found in considerable quantities on the ice. The male plant is smaller than the cystocarpic, and the antheridia may be detected by the naked eye in the form of small, whitish, glistening spots. The walls of the conceptacles are thinner than those of Delesseria. The swellings in which the tetraspores are borno can hardly be called warts, and the figure given by Harvey in the Nereis is somewhat exaggerated. The surface of the frond is raised, and becomes more or less convex, but there are no such irregular projections as represented in Harvej's figure.

\section{DELESSERIA, Lam.x.}

(In honor of Baron Benjamin Delessert.)

Fronds bright red, thin, membranaceous, laciniate or branched, costate, and often with lateral reins, composed of a single or a few layers of large polygonal cells; antheridia in spots on the frond; tetraspores tripartite, grouped in spots (sori) on the frond or on marginal leaflets; cystocarps external, sessile, with a basal placenta, from which radiate the numerous subdichotomous, sporiferous filaments.

A beautiful genus, comprising fifty or more species, distributed all over the globe. They are of delicate texture and rosy-red color, and are generally leaf-like in appearance, although some are narrowly linear. The genus is not likely to be mistaken for any other on our coast, unless it be Grinnellia, in which the tetraspores are borne in thickened portions of the frond. The fronds, when young, are more or less leaf-like and provided with a midrib, and generally also with lateral nerves; and, as they grow older, they become more or less stipitate by the wearing away of the blade of the leaf, which leaves the thickened midrib either naked or with a small winged margin. When still more advanced, owing to the growth of the lasiniæ and the wearing away of the lateral nerves, the stipes appear to branch and to bear several leaf-like fronds. In some species the membranous portion of the fronds consists of a single layer of cells, which are rectangular when seen in section and poljgonal seen from above. At the veins the cells form several layers, and in some species it is only at the tip that the fronds are formed of a single layer. When the cystocarps are formed, the cells are divided by numerous partitions parallel to the surface of the frond, and the wall of the conceptacle, when mature, consists of several layers of cells, all of about the same size and smaller than the cells of the frond.

D. Sinuosa, Lam.x.; Phyc. Brit., Pl. 259.

Fronds four to eight inches long and two to four broad, stipitate below, stipe often elongated and branched, with oblong or obovate, deeply sinuate or pinnatifid toothed leares, midrib percurrent, lateral veins opposite, extending to the lacinix; tetraspores tripartite, either borne in small lateral leaflets or in patches following the veins; cystocarps sessile, generally on the reins, hemispherical, with a distinct carpostome.

On algæ, generally in deep water. 


\section{From New Пaren northward.}

One of the more common Florided north of Cape Coul, and not rare in the colder waters of long lsend and Vineyard sounds. It is found all the year, but especially in the antumn amb winter. It is at onee recognized by the presenee of a midrib and lateral reins and ly its general resemblance in outline to an oak-loaf.

\section{Alata, Lam.x.; Phye. Brit., Pl. 247.}

Fronels two to four inches long, an eighth of an inch wide, stipritate below, ahore pinnately decompomel, dirisions linear, margin entire, costate, lateral reins scarcely visible; tetraspores tripartite, borne in the apices of the semments or in special leaflets; ('ystocarps hemispherical, on the upper reins.

Var. Axgestissma, Harv., Phye. Brit., Pl. 83.

Fronds very narrow, blade of the leaflets almost wanting.

From Boston northwarl, with the last; Europe.

A common species of Xorthern New England, but not yet fouml sonth of Cape Corl. Our form is uniformly narrower than the commen European form, and there is searcely a trace of lateral veins. Mypoglossum Grayanum, Reinsch, Contrihutiones ad Algologiam et Fungologiam, p. 5.5, Pl. 42, appears to he the same as 1). alata of the New England coast.

D. Lepriecrit, Mont.; Yer. Am. Bor., Part II, Pl. 2:) e. (Iypoglossum Leprieurii, Kiitz.-Caloglossa Leprieurii, J. Ag., Epicr.)

Fronds purple, one to two inches high, about a tenth of an inch wide, dichotomous, articulato-constricted, costate, proliferous from the costa, segments linear-lanceolate, attenuate, rhizoids and new leaflets formed at the constrictions; tetraspores tripartite, in oblique lines extending from the midrib to the margin; cystocarps sessile on the midrib.

\section{West Point, Builey; Fort Lee, I. Y., Mr. Averill; Harlem River,}

\section{H. Peck; and common southward.}

This small species inhabits tidal rivers where the water is warm, and is found on wond-work, stones, and water-plants. It is probally not rare near New York, and on our Sunthern Atlantie coast it is common. It extends to the West Indies, and is also fouml in the warmer waters of both hemispheres. It is distinguished at once from our other species loy its small size, purple color, and very thin eonstricted fronds. The species was placed by Harvey in the sulgrenus Cologlossu, which is seprarated as a distinct genus by Agardh in his Epicrisis.

\section{GRACILARIA, Grer.}

(From gracilis, slender.)

Fronds filiform or compressed, carnoso-cartilaginous, dichotomons or irregularly decompound, composed of an inner layer of large angular cells, which become smaller ontwards, and a cortical layer of small colored cells; antherinlia in ravities sunk in the cortex or superticial; tetraspores cruciate, dispersed in the cortical layer; eystocarps external, sessile, splherical or conical, with a larere cellular flacenta at the 
base, from which radiate the sporiferous filaments, pericarp thick and connected with the placenta by slender filaments.

A genus containing not far from forty species, none of which really deserve the generic name, for they are usually coarse and often decidedly cartilaginons. The specific distinctions are principally derired from the branching, which in the present genus is very variable. Some of the species, as G. lichenoides, are used as food.

\section{G. iultipartits, J. Ag.; Phyc. Brit., Pl. 15.}

Fronds purplish red, four to twelve inches long, compressed or submembranaceous, deepiy cleft vertically in an irregularly dichotomous or palmate mammer, dirisions linear wedge-shaped, acute; cjstocarps large, conical, scattered over the frond.

Var. Angustissnia, Harv.

Frouds narrow, nearly filiform below, compressed abore, irregularly dichotomous, the apices frequently palmately divided.

On stones and on muddy bottoms below low.

Massachusetts Bay, Harrey, and common from Cape Cod southrrard; Europe; California.

A coarse and rariable species, which is generally of a dingr purple color. The limits of the species are difficult to fix. Occasionally one finds with us specimens as broad as the common European form, but on the coast of California, and especially of Florida, one finds forms which look like large Phodymenice. Most of our specimens are narrower than the type, and the rar. angustissima of Harrer, it must be confessed, has more the habit of $G$. compressa than of $G$. multipartita. At Orient we have seen what we supposed was $G$. confertoides, but unfortunately our specimens were misplaced.

\section{SUBorder RHODOMELEA.}

Fronds usually filiform and branching, sometimes membranaceous or (in exotic genera) reticulate; antheridia orate or lanceolate in outline, formed by the transformation of monosiphonous branchlets, occasionally corering the surface of discoidal branches ; tetraspores generally tripartite, borne either in localized portions of the fronds or in specially modified branches (stichidia); cystocarps external, with a distinct orate or urceolate conceptacle or pericarp, spores prriform, borne on short stalks given off from a basal placenta.

The largest suborder of the Florider, and one containing mans of the most beautiful sea-weeds. The suborder is mainly characterized by the cystocarpic fruit, which is external, and has the spores borne separately on short stalks which arise from a placenta which surrounds the carpogenic cell at the base of the conceptacle. In the Dasyce, however, the filaments which bear the spores branch and fill the larger portion of the conceptacle, but we have not thought it advisable to separate them as a suborder. The antheridia, except in the genus Chondriopsis, where thes assume a peculiar shape, form orate or siliculose tufts, generally developed from monosiphonous branchlets or rather hairs. The position of the tetraspores varies in the different genera. In some cases the branchlets become broadly ovate and the tetraspores are 
lorme in paralled rows. Such collections of tetraspores are called tielhidia. The fromb in the present suborder vary greatly. In the more leantitul gensera of tropieal regions they are in the firm of complieateal net-works or in memleranes in which the cells are arranged in regular orter, lne in the majority of the gerera the fromls are tiliform and lranehing and gemerally heset, at least at some seasmes, with delieate

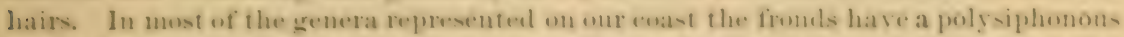
axis, that is, on cross-section there is seen to lee a central cell -urrounded ly a rirele of laree cells, and in longitudinal seetions there is a eentral filament compused of larere. rells, and en each side a lateral tilanent whene cells correspond in length to thene of the contral filanent, the upper and lower walls of the three colls forming two parallet lines.

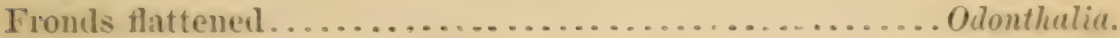

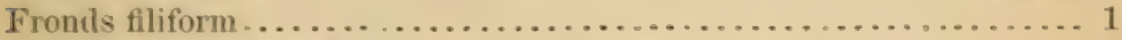

1. Tetraspores borme in the smaller bratehes ............. Tetraspores borne in stichidia .................... 4

․ Supreficial cells small, irregularly placed ................ 3 Suprerficial cells, at least in the gounger branches, in transverse

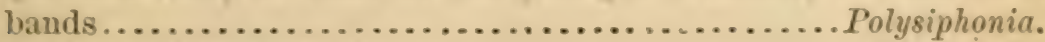

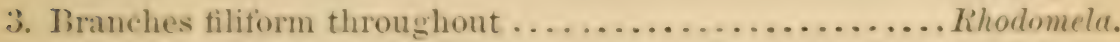
Ultimate branches elub-shaped, muchattemuted at hase. Chondriopsis.

4. Fromis beset with monosiphonous hranchlets............ Dusyrt. Fronds without monosiphonous branchlets, superficial cells quarl-

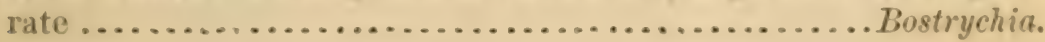

\section{CHONDRIOPSIS, J. $\Lambda$ g.}

(From xovipos, cartilage, and o\%,s, an appearance.)

Fronds lirownish red, terete or subeompresserl, pinnately decompound, banches virgate, much constricted at the hase, composed of a monosiphomous axis surrounder by a few (t-6) siphous and surrounded hy seeondary siphons, cortex of small polygonal cells; antherielia horne in short disk-like branchlets covering both surfaces except at the margin; tetraspores triphartite, in chu-shaped loranchlets; cystocarps sessile, ovate, with a distinct carpostome, spores pyriform, on short pedicels from a basal placenta.

A genns of which ahout twenty species have been de-criber. which inhahit primeiprally the warmer parts of the world, some leing widely diffused. They are as a whele. diffiente todistinguish, the specifie masks leeing prineipally the ramification and shape of the liranchlets points in which the different species rary rery much. The antherinlia are rery juentiar. On the upper loran hess are lurne dlattened, more or less in-

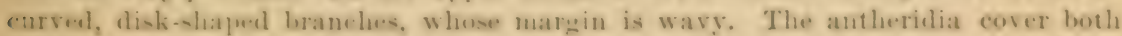
sides of these diendial hran lies, exrept at the margin, which is compesed of large hyaline ce-1ls. The tronds are intermediate between those of lihodemela and Laurencia, and the lianehlets are always much constrieted at the hase. Most of the species were formerly inelnited by Lamouroux andothers in the greuns Lauremin. By C. A. Agardh Uhey were, in the Fiee ies Algarum, placed in Clondria, a gemus retained hy Harrey in the Nereis. Sinee as origrinally defined the genus Chumdria embraced algre of rat her remoto relatimulip to me another, J. G. Agardh, in the third rolume of his Speecies Algarum, separated the present group, under the name of Chondriopsis, the naue Chondria heing 
abandoned altogether. The habit of the species of the present genus is much like that of Laurencia, but the polrsiphonous character of the fronds is more erident, the substance more delicate, and the branchlets more distinctly club-shaped than in that genus. As in Laurencia, the apices are all depressed, the growing point being sunk in a hollow concavity, from which, as $\pi$ ell as from the rounger part of the fronds, project numerous tufts of hyaline, dichotomous, monosiphonous filaments.

\section{Dastpinla, Ag. (Laurencia dasyphila, Phyc. Brit., Pl. 15̃.)}

Fronds dioecious, four to eight inches high, broadly prramidal in outline, cylindrical, robust, densely branched, generally with a percurrent axis and alternate, spreading, pimmately decompound branches, ultimate divisions short, club-shaped or top-shaped, rery obtuse at apex and much constricted at base; çsstocarps sessile on rery short branchlets.

Tar. stedffolia, Ag. (Chondria sedifolia, Ner. Am. Bor., Part II, Pl. 18 g.)

Branches fasciculate, approximate, branchlets obovate-oblong.

On rocks and stones at low-water mark, and on Zostera.

Common from New York to Cape Cod; Europe.

A rather coarse species which does not collapse when removed from the water, but which glisteus on account of the water held by the tufts of hraline filaments at the tips of the branches. The species is recognized br its coarseness and broadly pyramidal outline and by its club-shaped ultimate divisions. The variety has rather less obtuse tips and is not uncommon. In spite of its coarseness, the species quickly decays in fresh water.

C. tenurssma, Ag. (Laurencia tenuissima, Phrec. Brit., Pl. 198.Chondria tenuissima, Ner. Am. Bor., Part II, Pl. 18 f; Etudes Phycol., Pls. 43-48.)

Fronds dicecious, foufr to eight inches high, narromly pyramidal in outliue, cyliudrical, slender, rather loosels branched, with a percurrent axis and long, suberect, alternate, virgate, pinnately decompound branches, ultimate branchlets narromly fusiform, attenuated at both extremities.

Tar. Baileyaxa. (Laurencia Baileyana, Mout., Anm. Sci. Yat., Ser. 3, Tol. II, 1). 63.-Chondria Baileyana, Harv., Ner. Am. Bor., Tol. II, Pl. 18 a.-Chondria striolata, Farlow, List of Marine Algæ.)

Branches erect, subsimple, beset with slender curverl branchlets, which are much attenuated at base and blunt at the apex.

On stones at low-water mark.

Squam, Mass., and common in Long Island Sound; Europe.

A variable spccies, distinguished from the last by its lighter jellowish color, less dense branching, and slender fusiform branchlets. The typical form is common with us, but not so common as variety Baileyana, which was considered by Agardh to be the same as C. striolata Ag. The species seems to us rather to be a form of C. tonuis- 
sime, but it must he confessecl apporathing $C$. desyphylla. Basiley was inelined to refer

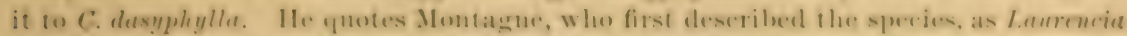

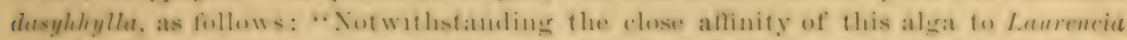
tenuissime and to L. desyphylla, it cammot be confoumeded with cither of them. The aherence of ramification distinguishes it suffieiently from the tirst, and the form of the

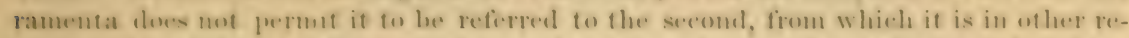
speets quife distinet." Just what is meant hy the "alesence of ramitieation," lyy which 1. Railegana is to le distingished from L. tenuissima, is not easy to see.

C. LrTtoral.s, (Harr.) I. Ag. (Chomdria littoralis, Ner. Am. Bor., Part II, 1. 22.)

"Fromds robust, elongate, sululichotomous or irregularly much bramehed, branches flexuous, attenuated, with rounded axils, ramuli seattered or crowiled, fusiform, attenuated at the base and apex, simple or pinnulated, acute." (IIarver, l. с.)

\section{Wool's IIoll, Mass., IV. G. F.}

The description taken from the Nereis applies protty well to a sperimen collected at Woerts Iloll. We have seen several speeinens of the speries collected at lieg Wist. It is tark colored and coarse, hut has the branching and habit of C. tenuissimu. The key We-t specimens are rechlish yellow, perhapss owing to exposure to the sun. Spreries of the present genus vary so much in appearanee, aceorling as they are more or les thormelily " sipuashed" in pressing, that the determination of dried specinens frequently has but little value.

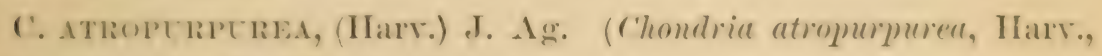
Ner. Am. Bor., Part II, Pl. 18 e.)

Frombls four to six inches high, robust, rery densely branched; branches patent, seenolary banches tapering at the hase and apex, bescet with seatterel fusiform ramuli.

Var. FAsciculata, Farlow.

Seeondary branches borne in clusters; (ystocarps broadly ovate, sessile on short lateral branchlets.

From Charleston, s. C., southward, Ilarrey. Var. fusciculute, Fort IIamilton, $\mathrm{X}$. Y.

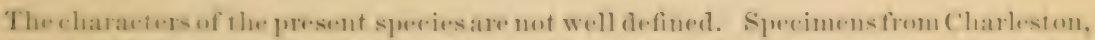

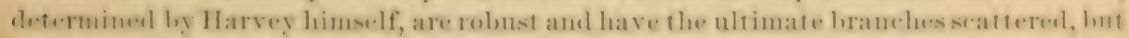
unfurtunately they are without frnit. What has been suppresed to lee a variety of the same speries oceurs rather commonly on the coast of C'aliforniat, and was distributed in

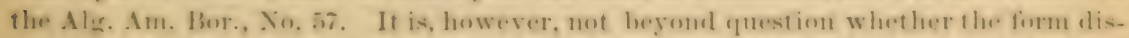

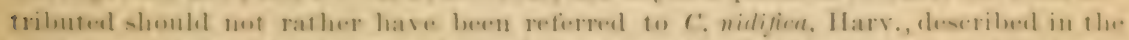

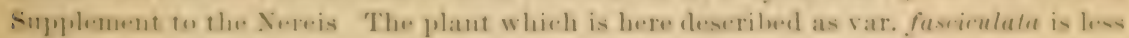
rohust than sjuerimens from Califirnia and Charleston, lont resemblesthem in the dark

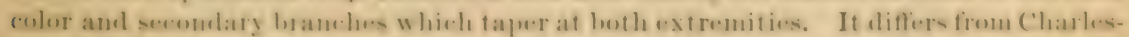

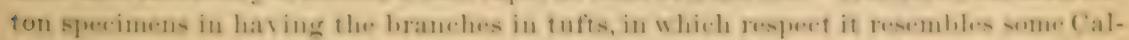
ifornian sperimems. Whether the .ew York form should ln. com-idered a rarieng of C. atropurpurea rather than C. nielifien is perhapes cloubthinl. 


\section{ODONTHALIA, Lyngb.}

(From odovs, a tooth, $a \lambda s$, the sea.)

Fronds dark purple, plane, deeply distichously pinnatifid, with a rudimentary midrib, margin alternately toothed, formed of oblong internal cells and small irregularly shaped cortical cells; tetraspores tripartite, arranged in two rows in short, corymbose, stipitate, lanceolate branchlets (stichidia), which are marginal and generally axillary; cystocarps similarly placed, orate, with a distinct carpostome and pyriform spores borne on a basal placenta.

A small genus of seven or eight species, which are confined mainly to the colder waters of the northern hemisphere. O. dentata occurs in the North Atlantic, extending as far south as Halifax. Several other species inhabit the North Pacific, especially the vicinity of Kamtschatka, one species occurring as for south as Japan and another in California. The species are dark and opaque, and the polysiphonous structure is scarcely visible in the older parts of the fronds, but is clearly seen in young shoots, especially in adventitious growths.

O. Dentata, Lyngb.; Phje. Brit., Pl. 34.

Exs.-Alg. Am. Bor., Farlow, Anderson \& Eaton, No. 56.

Fronds four to twelve inches long; quarter of an inch broad, decompoundly pinnate, branches oblong, deeply pimmatifid or bipinnatifid, lacinixe alternate, linear, sharply inciso dentate toward the truncated extremities; tetrasporic and cystocarpic branchlets clustered, axillary.

Halifax, N. S., and sereral localities on the Saint Lanrence Rirer.

This species has not jet been found within our limits, hut may be expected on the Maine coast. It is easily recognized by its color and ramification, and does not adhere to paper in drring. As a rule, American forms of this species are narrower than the common British form, but they are not distinct, and at Halifax the common British form was dredged by Professor Hratt in abmulance. The O. furcata of Reinsch, Contributiones ad Algologiam et Fungologiam, p. 58 , Pl. $42 a$, is apparently the common narrow form of the present species.

\section{RHODOMELA, J. Ag.}

(From $\rho \circ \delta \varepsilon o s$, red, and $\mu \varepsilon \lambda a s$, black.)

Fronds dark red, filiform or subcom pressed, pinnately decompound, branches filiform, not contracted at base, composed of a monosiphonous axis surrounded by several siphons and a thick cortex of small, irregularly placed, polygonal cells; tetraspores tripartite, kosne in the ultimate branches; rystocarps sessile or pedicellate, spores pyriform, on short stalks from the basal placenta.

A small gecuus of dark-colored algar, confined to rather high latitudes in both hemispheres. It is connerterl hy the genus liytiphlara with I'olysiphonia. The polysiphonous character of the fromd is seen at the tip, and in most species eross-sections of the stem show a circle of large cells surromeling the axial cell aud a thick cortical layer. When young the species are covered with dichotomous hairs. The genus is distinguished at sight from Chondriopsis by not having branchlets constricted at the base. 


\section{R. sunfuscs, Ag.; Phye. Brit., Pl. 264.}

\section{Exs.-1lg. Am. Bor., Farlow, Anderson \& Eaton, No. 55.}

Fronds six inches to a foot and a half long, terete, pimnately decom. pound, branches virgate, lower branchlets patent, subulate, the upper fisciculato-erymbose: tetraspores prominent in subtorulose branchlets; eystocarps sessile, orato-globose.

Var. cirdendor, J. Ag. (Rhodomela gracilis, Hars.. Ner. Am. Bor., Part II, Pl. 13 c.)

Fronds slencler; tetrasporic branches distinctly tornlose.

In cleep tiele-pools and at a depth of sereral tathoms.

\section{Throughout our whole limits; Europe.}

A species which varies very much with the time of year and the place of growth. It is usually common in the spring months, when it is often washecl ashore, and in the summer and autumn it is occasionally fomml, especially in dredging, in a denuded form, nothing remaining but the older branches, which are perennial and which gire rise the following season to rather delicate new branches. As usually seen on Cape Ann the fronds are short, robust, and dark colored, even in early spring, while at Woedl's Holl and in Long Island somnd the common spring form is much attenuated, delieatr. and of a hrighter red color, forming the lihodomela liochi of the Nereis. In spite of the difference in aspect, the extreme forms are comnected hy numerous transitimal stages which make it impossihle to ahnit a sperife distinction. By Agarilh R. Rochei is considered to be the spring form of the typical li, sulfuscu, but we are more inclinel to reraral it as the young of the var. grucilior, which is more common south of Cafe Cod, the type occurring northward. The species does not allhere well to pajur.

\section{POLYSIPHONIA, Grer.}

(From $\pi 0 \lambda v \varsigma$, many, and $\sigma \iota \phi \omega v$, a tube.)

Fronds filamentoms or subcompressed, distichously or irregulatly branching, formed of a monosiphonous axis and several (1-20) sijpons, often with secondary siphons, and either nalied or with a cortical layer of irregular cells, furnished with numerous tufts of hyaline, monosiphonous, dichotomous filaments; antheridia lanceolate in outline, borne on the dichotomous filaments; tetraspores tripartite, in one, rarely in two, rows, in the slightly altered upper branches; cystocarps ovato-globose or urcenlate; spores pyriform, on short pedicels borne around a basal carpogenic cell.

The largest genus of $I$ lorided of which more than two humbed species have been

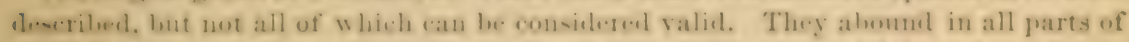
the woth, eprerially in warm, shallow waters. Some are peremial, lut the majority are annual amd disapjear during the winter. They are rasily recontized at sight loy the strueture of the fromel and the tertrasperes, which are alment always in a single row

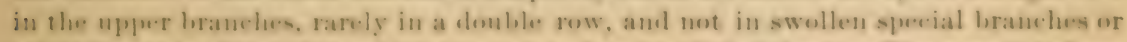

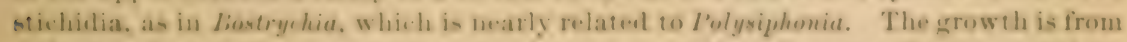
a single apical cell, from which is firmenl a monosiphomons axis. By tangontial divisions of the upper cells there is formed a number of peripheral cells and a central 
cell. The peripheral cells are similar to one another and of the same length as the central cell, and, as the successive secoulary cells lie exactly or nearly exactly over one another, the mature frond appears to be composed of a central filament or axis surrounded by a number of secondarc filaments or siphons, as they are termed in speaking of the present genus and its allies. There is formed in some species a second set of cells alternating with the siphons, and also corticating, generally irregularly sinuous cells, which corer the surface. The tetraspores, accorling to Prof. E. P. Wright, are formed by out-gromths from the axial cell. The antheridia are borne on the delicate, colorless tilaments which form tufts on the rounger parts of the frond. The filaments are dichotomons and the autheridia cover the lower cells of one of the forkings, the branch sumetimes being prolonged berond. when the antheridia are said to be mucronate. The crstocarps are terminal on short branches, and contain within a pericarp, whose cells are arranged in longitudinal series. prriform spores on short stalks around a small basal placenta. Some of our species are not rell detined, and a prolonged observation on the shore, especially during the spring months, is necessary before the limits of some species can be accurately fixed.

SECT. I. Siphons four, cortications wanting.

P. urceolata, (Dillw.) Grer.; Phye. Brit., Pl. 167.

Fronds deep red, becoming blackish, ciespitose, three to ten inches high, setaceous, branches sublichotomous, with short, alternate, patent or recurrerl, decompound branchlets, siphons four, cells below 4-5 times longer than broad, becoming shorter abore; crstocarps on short lateral branches, urceolate, with a distinct neck; antheridia linearoblong, mucronate.

Tar. Fonyosa, Ag. (Polysiphonia formosa, Phyc. Brit.)

Filaments soft and flaccid, branches long. flexuous, branchlets somewhat attenuated, cells $5-10$ times as long as broad.

Var. PAtexs, Grer. (P. subcontorta, Peck, Trenty-third Report New York State Botanist.)

Branches numerous, recurved or revolute.

On wharres and rocks at low. water mark.

\section{From New Jersey northward; Europe; California.}

A common peremnial species, most abundant in the spring. when it has a deep bloodred color. It is frequent on old wharres and wood-work and on the under surface of rocks near low-water mark, where it forms small turfs, in compans with Cullithamnion liothii. The var. formosa is found only in the spring, and is softer, forms longer tufts, and has longer cells than the trpe. It is the onls form of the species which udheres well to paper or which can las claim to beauty. It is especially luxuriaut in April at Wood's Holl and the region of Ner Bedford, and forms dense tufts sometimes a foot long. As usually seen in summer, the species is blackish and setaceous and covered with diatomes. The var. patens, which difters somewhat in general habit from the type, is not uncommon with us. Through the kindness of Mr. Peck, we have been ahle to examine a specimen of his $P$. subcontorta, which, judging from the description in the Twentr-third Report, seemed to be elosels related to, if not a form of, $P$. Harreyi. An examiuation of the specimen, however, seems to us to show that it is var. patens of the present species, which it resembles in microscopic characters.

P. subtilissma, Mont.

Filaments densely tufted, two to four inches long, purplish brown, 
rising from a creephing base, capillary, alternatels decompound, branches multificl, attenuate, hranchlets filifurm, internoules once and a half as long as broad.

Var. Westpoivtensis, Harv.

More slender and delicate.

Jackson Ferry, X. Y. : Xewburypont. Mass., Harrey; I'rovidenee, I2. I., Mr. Olney: Gloneester, Mass. ? W. G. F. The variety at West l'oint.

The present speries is w ith difliculty di-lingui-hed from $I$. Olneyi, which, in its turn,

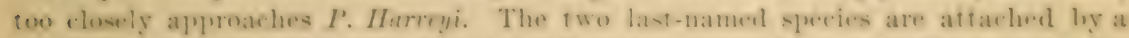
suall disk, and the tilaments de unt rise frosu at reepling hase, as in the pressent species. The vertical filaments of $I^{\prime}$ ' subtiliesime are of a purple color, and are tine and soft, and the cells are not much lonerer than lowad. We have seen specimens collecterl l.y M. (Hney near Providence which may with certainty be referred to the present, and have found thating in ditehes at (iloncester tufts of a very dark, delicate spereies which may probably be referred to it. The specimens were apparently washed from som. mulily shore, but the erepping hasal filaments could not be seen. Gloncester ewilectors shoml.l seareh for the plant in muldy ditches towards Little Good Hartor.

P. Or.xeri, IIarr., Ser. Am. Bor., Part II, Pl. 17 b.-Dough Balls.

Fromls brownish rerl, densely tufted, from two to five inches high, filaments eapillary. much branched. hranches patent or divaricate. decompumel, attenuated ahore, with scattered slender branchlets. internoles three or four times as hroal below, becoming shorter above; anthericlia ellipsoislal, not mucronate: cystucarps hroadly ovate, nearly sessile.

\section{On Zostera.}

From Sew Fork to Malifax, most co:nmon south of Cape Coul.

The present species passes by numerous forms into $I^{\prime}$. Hareryi, and in spite of the marked difference in the typulal forms of the two species, the question remains to he settled whether $P$. Olneyi is not a slemeler variety of $P$. Harreyi. In its typical form I. Cluryi forms dense soft tufts, sometimes called dough-balls by the sea-shore population. The filaments are divarieately branched below, but the upper branches are slender and ereet and beset with fine byssoid branchlets. When oll, howerer, the dower liranches become rigid, and the branchlets rather spine-like, as in the next spe. cies. Loth I'. Olneyi and I'. Ilareyi are very common from Cape Coul to .iew Jork, growing nonally on Zowera in shallow, quirt hars. As they mature they fall from the Zostra and are blown inte small cores, the loottoms of which are sunetiues almust

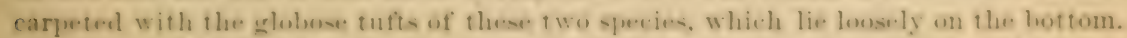

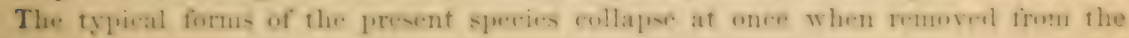
water.

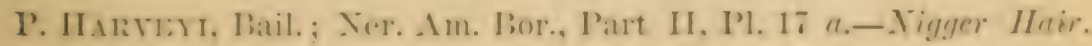

\section{Pl. XV, Figs. 3, 4.}

Fromels blackish rrel. globosely tufterl, tilaments two to six inches high, setatceots, when young with a leading axis, hecoming divarieately much leranched. branches alternately decompouml, patent. often angularly bent, beset with numerous short, simple or forked, spine-likes 
branchlets, internodes all short, never more than twice as long as broad; antheridia ellipsoidal, not mucronate; cystocarps broadly orate, on short pedicels.

On Zostera and other plants.

Common in Long Island Sound and found in several place in Massachusetts Bay; Goose Cove, Squam, Mass.

The typical form of the species is closely related to $P$. spinulosa, Grev, found in Scotland and in the Mediterranean and Adriatic Seas, where, however, it does not appear to be at all common. We once collected specimens at Antibes, France, and certainly at first sight it could not be distinguished from $P$. Harveyi. In the typical $P$. Harreyi the branches are rather rigid and the branchlets are spine-like and sometimes revolute. As the plant grows old the finer branchlets disappear, and there is left an irregular mass of coarse filaments beset with revolute branchlets, forming the $P$. arietina of Bailey, which is in the Nereis considered a variety of $P$. Harceyi. It is, however, rather an autumnal condition than a proper variety. The upper portion of the fronds of $P$. Harveyi are sometimes slender and byssoid, and as it is a well-known fact that the branchlets of Polysiphonia have the power of falling from their attachments and producing new plants, it may be, as has already been suggested, that $P$. Olncyi is the byssoid condition of $P$. Harveyi.

Polysiphonia Americana, Reinsch, Contrib. ad Algolog. et Fungolog., p. 50, Pl. 33 a, as far as can be judged by the plate, closely resembles some forms of $P$. Harreyi, except. in the color, which as given by Reinsch is bright pink. It is said by Reinsch to resemble $P$. arietina, Bailey, in general appearance, but to differ in the erect, subdichotomous filaments, whose joints are bicellular.

SEc. II. Siphons four, main branches corticated, ultimate branches without cortication.

P. elongata, Grer.; Phyc. Brit., Pls. 292, 293.-Lobster Claws.

Fronds dark red, six to twelve inches long, robust, cartilaginous, irregularly branched, lower branches naked, upper beset with closely set, alternately multifid branchlets, which taper at the base and apex, cortications covering all but the younger portions of frond, section of branches showing four large siphons, with secondary siphons and a rather thick cortex; cystocarps orate.

Gloucester, Lynn Beach, Squam, Wood's Holl, Gay Head, Mass.

One of the largest but less common Polysiphonia, which is more abundant in the spring than at any other season. The species is perennial and in late summer and autumn the branchlets fall off, leaving the lower and coarser branches, which persist through the winter, and in the following spring produce at the apices tufts of delicate, recp-red branchlets. It is recognized by its long cartilaginous main branches, which are nearly naked, and which bear tufts of filaments at the apex. The popular name of lobster claws is tolerably appropriate.

P. fibrillosa, Grev.; Phyc. Brit., Pl. 302.

Fronds brownish yellow, four to ten inches high, broadly pyramidal, rather robust below, becoming slender abore, with an undirided axis or dirided near the base into several long, main branches, secondary branches alternate, sereral times pinnate, fibrillose, with short, scattere d, 
simple branchlets, ultimate divisions capillary, tufted ; antheridia oblong, terminal ; cystocarps orate.

On stones and Zostera at low-water mark.

Lyun, Malss., Herrey: Wood's Holl, Yoank, Orient Point, Yewport, and several places in Long Island sound; Europe.

Rather a common species in sheltered places south of Cape (col, hut only known northward from the reference of Harvey. It is smaller and more slemeler than the last species and the branches are not naked, hut fibrillose. The present speries is more nearly related to $I$. violacen, of which Harvey sngerests that it may be a variety. The last-named species is more decidedly real in color, is a largrer plant, and although the ultimate branches are in fufts, as in $P$. filrillesa, the larger hranches are destitute of the fibrillose branchlets characteristic of the latter species.

P. violacen, Grev.; Phyc. Brit, Pl. 209.

Fronds brownish red, six inches to two feet long, elongated, pyramidal, usually with an undivided main axis, which has several long, widely spreading branches near the base, main divisions robust, becoming capillary at the tops, branches rather naked below, bearing above numerous multifid branchlets, ultimate branchlets densely tufted; antheridia? cystocarps broadly orate, sessile or shortly pedicelled.

Var. Flexicaulis, Harv.

Branches very long, slender, angularly bent, much divided, divisions patent and sometimes secund.

In deep tide-pools on exposed shores and on Zostera in deep water.

Common from Yew York northward. Tar. flexiculis, Cape Ann; Portland, C. B. Fuller; and northward.

One of the commonest species of the genns, frequenting cold, exposed tile-pools, where it has a dense habit and rarely exceeds a foot in length. When growing in cleep water it is long and slender. In spring it has a pink color, but late in the season it becomes dark colored, almost blackish. Specimens of the present sprecies are sometimes fouml in American herbaria bearing the name of $P$. Brodici, a species having six siphons, which has not as yet been detected with certainty on our coast. The $I$ '. Brodici uf Bailey's List of Luited States Alga is, according to Harvey, I' fibrillusa.

Sect. III. Siphons more than four, corticating cells ucanting.

P. vanteg.atA, Ag.; Phye. Brit., Pl. 155; Ann. Sei. Nat, Ser, 3, Vol. XVI, Pl. 6.

Fronds purplish hromn, densely tufted, four to ten inches high, filaments setaceous and rigid below, capillary above, dichotomo-multifid, the lower axils patent, branches above somewhat zigzag, elongated, with alternately decompound, flaceid branchlets, siphons six in number, cortications wanting, internodes not much longer than broad; antheridia linear-oblong, mucronate; cystocarps ovate, short-stalkedl.

At the foot of wharres, on Zostera, \&e. 


\section{Massachusetts Bay, Harrey; common from Cape Cod to the IVest} Indies; Europe.

A beantiful summer species, forming large purple tufts on wood-work and various substances a short distance below low-water mark in warm, sheltered waters. The lower branches are rigid and widely spreading, but the tips are byssoid and collapse on being removed from the water. When mounted on paper small specimens have a slight resemblance to $P$. Olneyi, but the species is coarser, and the siphons are six instead of four in number.

\section{P. Parasitica, Grev.; Phyc. Brit., Pl. 147.}

Fronds dark bromnish red, one to three inches high, filaments compressed, decompound-pinnate, branches alternate, distichous, 2-3 pinnate, ultimate dirisions erecto-patent, subulate, acute, internodes about as long as broad, siphons 8-9, cortications wanting; cystocarps ovate, on short stalks.

\section{Proridence, R. I., Harvey; Europe; California.}

A small species, said to hare been collected by Mr. Hooper on the authority of Harvey. It differs from our other species in the compressed frond and uniformly distichous arrangement of the branches. In aspect it looks more like a fine Ptilota than a Polysiphonia. In drşing it does not adhere well to paper. In California the species is rather common, especially the large variety dendroidea.

P. Atrorubescens; Grev.; Phyc. Brit., Pl. 172.

Fronds tufted, dark red, two to twelve inches long, filaments setaceous, rather rigid, branches long, erect, alternately decompound, with scattered, simple or virgately tufted branchlets, which taper at the base and apex, siphons usually 12, spirally twisted, articulations generally 2-3 times as long as broad; antheridia oral, terminal; cystocarps broadly ovate, sessile.

In deep water and washed ashore.

Gloucester, Mrs. Davis; Gay Head, Mass., W. G. F.; Fisher's Island, Prof. Eaton; Orient, L. I., Miss Booth; Noank, W. G. F.; Little Compton, R. I., and Long Branch, N. J., Harvey; Europe.

One of our less common species, recognized by the number of siphons, which are usually spirally twisted, and by the long branches, which bear small branchlets that taper at both extremities. Late in the season one finds denuded, rigid specimens, which bear little resemblance to the form found early in the season. It does not adhere well to paper in drying, and becomes quite black in the herbarium.

\section{P. NIGREscens, Grev.}

Fronds dark brown, three to twelve inches long, rigid below, becoming flaceid and much dirided above, branches alternate, decompoundpinnate, ultimate branches subulate, siphons 12-16, articulations about 112-3 times as long as broad; antheridia lanceolate, mucronate; cystocarps orate, subsessile. 
Var. Fucondes, Ag.; Phye. Brit., Pl. 277.

Frouds rolust and naked below, upper loranches prectinate or corymbose, articulations but slightly longer than broat.

Var. AfFinis, Ag.; Phye. Brit., Pl. 303.

Fronds elongated, diflusely branehing. branches distant, undivided below, densely pinnate at the tip, artionlations two or three times as long as broad.

In tide-pools and below low-water mark on stones and algar.

Common along the whole coast.

One of our eommonest and least beantiful species, which, althungh very variable, is generally easily recognized. In the Nereis, Harsey deacribes seven forms foumd on our eastern coast. Practically, the spectes as fomml with us is recognizend under two principal forms. The first is rather robust, and has branches which are more or less peetinate or corymbose, and in the extrene forms, as rar. Durkeci, Harr.. 1. c., II. 17 c, they are eompressed, and the pinne are distichens and abloreviated. The second form of the species is represented hy the P. affinis of the Phycologia Britannica, in which the main branches are much elongated and more clelicate than in var. fucoides, ant the ultimate divisions are arranged in pyramidal tufts. Between the two types described occur innumerable forms which hardly require a further description.

P. Fastigiata, Grev.; Phye. Brit., Pl. 299.

Fronds dark brown, forming globose tufts one to three inches in diameter, filaments rigid, of nearly the same diameter throughout, repeatedly dichotomous, fastigiate, apices subulate, spreading, occasionally forcipate, siphons a veraging about 20 , articulations decidedly broader than long; antheridia oval, in dense terminal tufts; cystoearps ovate, taking the place of a terminal dichotomy.

\section{On Ascophyllum nodosum.}

Common from New York northward; Europe.

A very common species, at once recomized by its form and place of growth. It forms tufts on Fucus (.Ascophyllum) nodosus and, according to Harvey, on $F$. rexiculosus. Its color is so dark that one at first sight would hardly suppose it to be one of the Florider. The filaments are rigill, and the plant does not collapse in the least when removel from the water, nor does it adhere to paper in drying. The antheridia are rery abunlant early in the season. The species, like most of the genus found on onr coast, is direcions, hut occasionally one finds loth sexes on the same individual. In this connetion, it would be well to incuire if there is not a proterandrous condition among the Florider, as in the higher plants. It has seemed to us that such a condition mas exist in $P$, rariggate, and presibly in the present species. P. fastiginta is said to have been eollerted in Califurnia, but the lowality is cloubtiul. It has been found also in Australia and Siew Zealand.

\section{BOstrychis, Mont.}

(From Buorpexiov, a small curl.)

Fromls dark purple, compressed or filiform, distichonsly or irregu. larly branching, composed of several (1-11) (ells isiplons) arranged around a central filament, the siphons either naked or corticated with subenbieal cells, apices usually mono-iphonous: tetraspores tripartite, 
in a double row in terminal fusiform branches (stichidia); cystocarps terminal on the branches, orate, with a distinct carpostome, spores pyriform, attached to short filaments which are giren off from a basal placenta.

A genus of about twentr species, characterized by their lurid purple color and by growing in places where the water is not very salt, some species, it is said, even growing in fresh water. Ther inhabit principally the tropics. The genus is intermediate between Polysiphonia and Dasya, and some species have been previously referred to Rhodomela. The tetraspores are in stichidia, as in Dasya, but the crstocarpic spores seem to us more nearly like those of Polysiphonia. The frond is originally monosiphonous, and soon becomes polssiphonous, the number of siphons not being as constant as in Polysiphonia. The corticating cells, when present, are regularly arranged in transverse bands. The development of the froud has been studied in detail by Dr. Ambronn in B. scorpioides.

B. rivularis, Harv., Ner. Am. Bor., Part II, Pl. $14 d$. Exs.-Alg. Am. Bor., Farlor, Anderson \& Eaton, No. 54.

Fronds an inch high, capillary, rising from a procumbent base, branches flexuous, bipinnate, pinnæ distichous, alternate, patent, loosely pinnulate, pinnules subulate, section of main branches showing about seren siphons; tetraspores cruciate, in two rows in oblong stichidia below the tips; crstocarps orate, terminal on the shortened, naked, lower pinnæ.

On submerged logs in patches.

Hell Gate, N. Y., Harrey; Fort Lee, N. Y., Ir. Averill; College Point, Astoria, C. H. Peck; common southward; Australia.

A common species from Charleston, S. C., southrard, but only occasionally found with us. The only certain localities are near New York City, and it is extremely doubtful whether it was ever found in the aretic waters of the Isle of Shoals, where it was reported by Captain Pike. The species is small and rather insignificant, but is easily recognized by its polysiphonous structure and ramification. There are no cortications, and the species belongs to the subgenus Stictosiphonia.

DASYA, Ag.

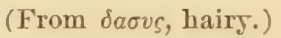

Fronds bright red, filiform or compressed, distichously or irregularly branching, composed of a monosiphonous axis surrounded by sereral (4-12) siphons, often corticated with irregularly shaped cells, clothed in the upper part or throughout with colored, monosiphonous, dichotomous branchlets; antheridia in siliculose tufts on the branchlets; tetraspores tripartite, borne in regular rows in lanceolate or orate-lanceolate enlargements of the branchlets; cystocarps orate, acuminate, sessile or pedicellate, spores terminal on branching filaments arising from a basal placenta.

A large and beautiful genus, including about serenty species, of which the greater part 
are tropical, Anstralia leeing eqpecially rich in speecies. The genus is divided into a number of subgenera, and is conneeted dy leostrychia and Toniome with I'olysiphomin. The tetraspores are in stichidia borne on the hair-like branchlets, while in Boseryelice they are in the polysiphonous branches, and in Tonioma the stichiclia are formed from the flattenewl and scarcely altered hranches. The eysecarpes are lorne on short lateral branches, which are usually slightly prolonged liegond the hase of the eystowarp. The placenta of Insyg differs somew hat from that of I'olysiphemia and our other genera of lihedemelee. The spores are ferriform, but are borne on rather long loranching filanents which surround the carpogenic cell at the base of the conceptarle, and which rise high up in its interior instead of leeing nearly sessile aromel the carpogenie cell, as in Polysiphonia. The development of the cystocarp has been studied in detail by Janezewski in 11. eoceinea. The fromels are either tilamentons or more or less Alattened, and, as in the case with most of the suborder, are formed from a monosiphonous axis, from the cells of which whorls of filaments are griven off, which in the ohler parts of the froml become parallel to the ax is and replace the siphons of Polysiphonia. In most of the grenus there are also secondary siphons and cortieating (c)-1ls, and either at the tip or throughout the frond tufts of delicate, dichotomons, monosiphonous liranchlets, which are colored and not hyaline, as in the hairs of some other genera.

D. Elegars, Ag., Sp. Alg. (Rhodonema clegans, Martens.-Dasya peclicellata, Ag., Syst.; Bailey, in Am. Journ. Sci., Vol. III, p. 84.)-Chenille. $\mathrm{Pl} . \mathrm{XV}$, Fig. 1.

Exs.-Alg. Am. Bor., Farlow, Anderson \& Eaton, No. $\check{1}$.

Fronds dicecious, villous, lake-red, six inches to three feet long, cylindrieal, attached by a small disk, alternately 1-3 pinnate, with a percurrent axis, densely clothed throughont with tufts of purple, capillary, monosiphonous, dichotomous branchlets, sections of branches showing five cells around the axial cell ; antheridia densely covering the lower cells of one of the divisions of the branchlets; tetraspores in two or three rows in linear-lanceolate or orate pointed stichidia on the branchlets; cystocarps sessile on very short branches (pedicels) which are borne on the main branches.

On Zostera, wharves, \&c., below low-water mark.

Common from Cape Cod southward; Adriatic Sea.

A heantiful species, known to lady collectors hy the name of chenille, at once recognized by its long. eylindrical, luranehing fromb, densely fringed with the lake-colored filaments. It is found thronghout the year. In drying it adheres elosely to paper. The antherilia are much like those of Polysiphonia rariegata, lout are longer. The species extends to the West Indies, but appears to he more common in Long Island sound than elsewhere. There is in the collection of the Peabody Academy of Salem a wry large specimen, said to have been collected at Ipswich Beach, Mass., but the localiry must ler regarded as doubtful. At any rate, the species is quite unknown .lsewhere north of Cape Cod.

\section{Stborder CORALLINEA, Decaisne.}

Fronds rose-colored or purple, calcareous, horizontally expanded or erect and branching, crustaceous, foliaceons, or filiform, continuous or 
articulated; antheridia, carpospores, and tetraspores borne in distinct carities (conceptacles), which are either external or immersed in the fronds; antherozoids spherical, attenuated at one end, or provided with two short projections borne on short filaments at the base of the male conceptacles; carpospores prriform, terminating short filaments which surround a tuft of paraphyses at the base of the female conceptacles; tetraspores zonate, occasionally binate.

The present order includes all the calcarenus Floridea except a comparatively few species which belong to the Nemaliea and Squamarica. Although classed by the earlier writers with the corals rather than plants, the species of Corallinece are now placed at the head of the Floridea, in consequence of their highly differentiated organs of fructification. Our knowledge of the fructification of the Corallinece is derived principally from the Études Phycologiques of Thuret and Bornet and the Recherches Anatomiques sur les Melobésiées of Rosanoff. Thuret and Bornet describe three different forms of conceptacle, containing, respectively, the antheridia, the carpospores, and the tetraspores, the last only being mentioned by Harvey in the Nereis. The tetraspores, which are wuch more common than the carpospores, are usually zonate, although occasionally binate, and from the fact that they are borne in distinct conceptacles, which is not the case with the other Floridea, it had erroneously been considered that the carpospores of the Corallince were four-parted. The cystocarpic spores, or carpospores, are always pyriform and undivided, and accompanied by paraphyses. The number of trichogynes is large, and they project in a tuft at the orifice of the conceptacle at the time of fertilization. The antherozoids differ from those of the other Floridew in having appendages.

The Corallinea abound in the tropics, and but few representatives are found in northern seas. Our own coast is especially poor in species. The study of the development of the plants of this order is difficult, owing to the calcareous deposit, and soaking in acid injures the more delicate parts. The species are nearly all fragile when dried, and it is not easy to preserve herbarium specimens in good condition. The suborder may be divided into two tribes. The Corallinex proper have articulated fronds, which rise vertically from the substratum, as is seen in our common Coralline. The Melobesiex are not articulated, but form irregular horizontal crusts, which sometimes rise in irregular erect branches.

Fronds erect, filiform, articulated ....................... Collina. Fronds horizontally expanded or vertical and inarticulate.

Fronds horizontal ......................................... Fronds rising in irregular protuberances from a horizontal base,

Lithothamnion.

\section{CORALLINA, Lam.x.}

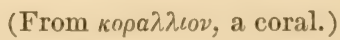

Moncecious or diœecious, fronds arising either from a calcareous disk or from interlaced filaments, erect, terete or compressed, articulated, branched, branches opposite, pinnate; conceptacles terminal, naked or occasionally with two horn-like appendages.

A genus comprising alyout thirty to thirty-five species, mostly tropical, C. officinalis, $C$. squamata, and a few others extending high northward. The fronds of Corallina are former of a bundle of dichotonous parallel filaments, whose external branches grow 
oblipuely out wardsto form the cortical layer. The increase in the length of the frond arises from the elongation of the central bundle of filaments. The whole plant is covered loy a dense cuticle. The conceptacles are formed from the terminal cells of the filaments just mentioned, which cease elongating and lose their caleareous incrustation, the euticle also falling away. The peripheral filaments, at the same time, continue to clongate and preject beyond the contral bundle of filaments, thus forming the wall of the conceptacle.

C. officinals, L.; Plyge Brit., Pl. 20.)-Common Coralline.

Dineious, fronds two to six inches high, arising in dense tufts from a calcareous disk, decompound-pimnate, lower articulations cylindrical, twice as long as broad, upper articulations obconical or pyriform, slightly compressed, edges obtuse; conceptacles ovate, borne on the ends of the branches, or some of them hemispherical and sessile on the articulatious.

Var. Profunda, Farlow.

Fronds elongated, with few, irregular brauches.

Common in tille-pools; the variety in deep water.

Europe; North Pacific?

The only species known on our coast, often lining the bottons of prols, and when exprosed to the sun becoming white and obleached. C. squamata, which is monorcious, and has a filamentons base, and whose upper articulations are compressed with sharp e'ges, especially on the upper side, is a common species of Northern Erirope, aud may bo expected with us.

\section{MELOBESIA, Aresch.}

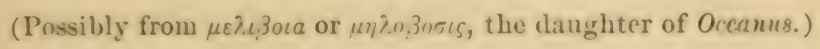

Fronds calcareous, horizontally expauded, orbicular, becoming confluent and indefinite in outline, conceptacles external or iminersed; antherozoids spherical, furnished with one or two short projections; tetraspores either two or four parted, borne sometimes in conceptacles laving a single orifice, at other times in conceptacles having several orifices.

The limits of the three genera Melobesia, Lithophyllum, and Lithothamnion are not well defined. In M. Thuretii, Bornet, the plant consists merely of a few short filaments, which are buried in the sulstance of Corallina squamata and several species of Jania, upon whose surface the conceptacles of the Mrluhexia are alone visilule. From this thereirs, in which the frond may be said to be rudimentary. we pass throngh forms in which the froml is in the form of calcareous crusts or plates till we meet heavy, irregnlarly branching forms, which resemble corals much more than plants. In the present fajur, Melolnsin, inelnding Lithophyllum of Rosanoff, comprehends all the smaller and thiner forms in which the frombl dows not rise in the form of irregular tulwereles or

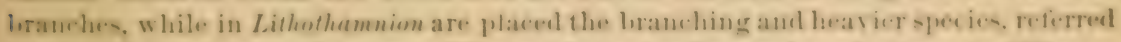
ly the wher writers, as Limuans, Lillis and Solamder. Lamarek, and on liers, to Millopora

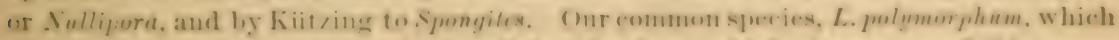
deses nof often hraneh, shows the insuffecent hasis on which the genera of this group rint. Althengh there is considerable disersity in the stmeture of the fromals, the organs of fructitication, with some slight modifications of the antherosids and tetraspores are the same as in Corallina and Junia. The unst detailed accoum of the 
frond in the Melobesioid group is that given by Rosanofî in his work already referred to. According to Bornet, howerer, the esstocarpic fruit of the Melobesia escaped the observation of Rosanoff, and what the latter called cystocarps were only a form of the non-sexual or tetrasporic fruit. The tetraspores are found in two different formseither in hemispherical conceptacles, which have a single central orifice of good size, at whose base the spores are borne around a central tuft of paraphyses, or else in truncated conceptacles, whose flattened upper surface is perforated with numerous orifices, beneath each one of which is a tetraspore, separated from its fellows by a large, colorless cell.

The fronds of the swaller species of Melobesia, as .Y. Lejolisii and M. farinosa, consist of two portious, the basal and the cortical. The former consists of a single layer of cells, which arise from the division of the spore into four cells and subsequent marginal growth. The cortical layer in the smaller species is composed of small cells cut off by oblique partitions from the upper part of the basal cells. In the larger species of Melobesia, more particularly those placed in the subgeuus Lithophyllum, the cortical layer is much more marked, and the cells of which it is composed seem to be arranged in lines which are curved at the base, but are straight above and at right angles to the direction of growth. In some of the small species of Melobesia certain of the basal cells elongate and swell at the summit, so that when seen from above they look larger than the neighboring cells. Rosanoff applied to such cells the name of heterocysts, a word badly chosen, since the heterocysts in the Nostochinea, where the term was first employed, cannot well be compared with the heterocysts in Melobesia. The conceptacles in all our species of Melobesia are external. The form generally found is that which contains the tetraspores. Our species all occur in Europe, and it is very probable that the remaining Northern European forms not yet recorded with us will be found on further search.

a. Species small, growing on plants, basal stratum well markicd, cortical layer imperfectly developed.

M. LEJolisir, Rosanoff. (1I. membranacea, Aresch., in Agardh's Spec. Alg.; Harrey, Phyc. Brit., Pl. 347, in part.-M. farinosa, Kütz., Spec. Alg.; Le Jolis's Liste des Algues.-M. Lejolisii, Rosanoff, 1. c., p. 62, Pl. 1, Figs. 1-12.)

Fronds thin and brittle, at first orbicular but soon densely confluent, forming scaly patches of indefinite extent; heterocysts wanting; basal cells squarish, cortical cells few and indistinct; tetrasporic conceptacles very numerous, approximate, flattened-conrex, orifice ciliated; tetraspores four-parted; antheridia and cystocarps?

On leaves of Zostera.

Wood's Holl, Mass.; common from Nahant northward; Europe.

A species which is certainly common on eel-grass on the northern coast and probably equally abundant in Long Island Sound, although definite information on this point is wanting. This is the form which is found in American herbaria bearing the name usually of $M$. farinosa or $M$. membranacea. The orbicular character of the fronds soon disappears, as they are found in great numbers, and at an early stage become confluent. The conceptacles are so numerous that at times very little of the fronds themselves can be seen. The latter easily crumble and fall from the plant on which they are growing.

M. FARinosa, Lam.x. (M. farinosa, Aresch., in Agardh's Spec. Alg., non Le Jolis's Liste des Algues._M. farinosa and M. verrucata? Harrey, in part._M. farinosa, Lam.x., in Rosanoff, 1. c., p. 69, Pl. 2, Figs. 2-13.) 
Fronds thin, orb:enlar, becoming confluent, distinctly zonate; hetero. eysts present, basal cells elongated-rectangular, cortical cells semicirenlar or triangular seen from above; tetrasporic conceptacles small, hemispherieal, orifice not plainly ciliate; tetraspores four-parted ; antheridia and cystocarps?

On Fucus vesiculosus.

Wood's Holl, Mass; in all parts of the world.

Althongh only one locality is mentioned, the species probably oceurs throughomt our limits. It is distinguished from the last hy the shape of the comereptacles and the alisence of a circle of eilia around the orifice. The fromds are larger and more frequenty orbicular, althongh searcely thicker than in M. Lejolisii. In both species the. calcareous incrustation is somewhat farinaceous as compared with the following, in which the incrustation is smoother and solid. Y. membrameren, Lan. x. related to .M. ferinosu, hut destitute of heterocysts and having tetrasporic conceptacles with severol orifices, is to be expected on algæ of our coast.

M. pustulata, Lam.x. (M. pustuluta, Phyc. Brit., Pl. 347 d; Rosanoff, 1. c., Pl. 4, Figs. 2-8.)

Fronds rather thick, circular, becoming reniform or orbicular, indistinctly zoned; heterocysts wanting, basal cells elongated vertically, cortical cells squarish; conceptacles large, hemispherical, orifice naked; tetraspores four-parted.

Prohably common on the larger algra along the whole coast, but heing undistinguishable from the next species when sterile, one cannot be sure of the species unless it is in fruit. The tetraspores of $M$. pustulata are zonately four-parted, while those of $M$. macrocurpa are merely two-parted at maturity. In hoth species the fronds are rather thick and solid and do not crumble, as in the two preceding species, and the orbicular shape is preserved for a longer time.

M. mactocarpa, Riosanoff. (M. macrocarpa, l. c., P. it, Pl. 4, Figs. 2-8 and 11-20.)

Fronds as in M. pustulata ; tetraspores large, two-parted.

\section{On Chondrus.}

Gloucester, Mass.; Europe.

b. Species rather large, growing on stoncs and shells, cortical stratum rell dereloped.

M. Lexormaxd, Aresch. (Lithophyllum Lenormandi, Rosanoff, 1. c., 1. 85, Pl. V, Figs. 16, 17; Pl. VI, Figs. 1, 2, 3, 5.)

Fronds saxicolous, closely adherent to the substratum, suborbicular, becoming squamulose-imbricate, slightly zonate, margin crenate, lobed; tetraspores four-parted, in compressed, hemispherical conceptacles, with numerous orifices; antheridia and cystocarps?

On stones.

Gloucester, Mass. ; Europe.

Apparently conumon in many places, but fruiting specimens were only collected at 
Gloncester. The fronds form rose-colored crusts of considerable extent, and are so closely adherent that they can scarcely be removecl. The tetrasporic conceptacles are large, but very much flattened.

\section{LITHOTHAMNION, Phil.}

(From $\lambda \iota \vartheta \circ s$, a stone, and $\vartheta \mu \nu \iota o v$, a bush.)

Fronds calcareous, thick, at first horizontally expanded, but afterwards produciug erect knobs or coralloid branches; otherwise as in Melobesia.

A genus comprising probably not more than twenty or twenty-five good species, most of which are tropical. The larger and more solid forms inhabit deep water. In Lithothamnion the cortical portion is markedly developed, and it not rarely happens that new lobes are produced which orerlap the older ones and form an imperforate layer over the older conceptacles, which are this occluited before the spores are ripe. In such. cases sections show conceptacles which are apparenty buried in the central part of the frond.

L. POLymorpinum, (L.) Aresch. (Hillepora polymorpha, L.; Sp. Alg.Millepora (Nullipora) informis, Lamarek.-Melobesia polymorpha, Harres, Phye. Brit., Pl. 345.)

Fronds thick and stons, purplish, becoming whitish, forming incrustations of indefinite extent and occasionally rising in thick clumsy lobes, punctate throughout with the rery numerous, small, immersed conceptacles; antherozoids spherical, with an appendage at one end (Bornet); tetraspores two-parted; cystocarps?

On rocks and stones in deep pools and below low-water mark.

Common from Nahant northward.

Not known with certainty south of Cape Cod, but very common northward, where it forms stony, purplish incrustations on rocks. As usually seen, it adheres closely to the rocks, covering patches of indefinite extent, and would be mistaken for a species of Melobesia. It is so hard and adherent that it is mistaken by persons on the shore for a part of the rock itself. Although the determination of the present species admits scarcely a doubt, the form usually found with us is smoother and less lobed than European specimens of the same species. In the description given above the tetraspores are said to be two-parted. This is true of all the American specimens examined, but it may be that what we have seen were immature spores, which, when ripe, are four-parted.

L. Fasciculatum, (Lamarek) Aresch. (Millepora fasciculata, Lamarck._Melobesia fasciculata, Harv., Phyc. Brit., Pl. 74.)

Fronds purple, stony, attached, afterwards becoming free, very irregular in outline, densely branching, branches fastigiate, subcylindrical, apices generally depressed; tetrasporic conceptacles densely covering the branches, flattened, hemispherical; tetraspores two-parted.

On stones or in free globose tufts at low-water mark and in deep water.

Eastport, Maine; Europe. 


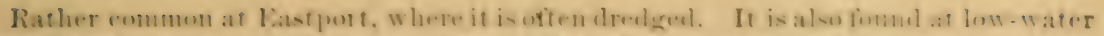

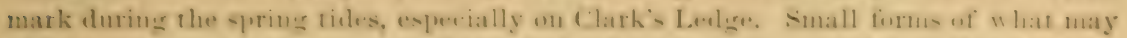

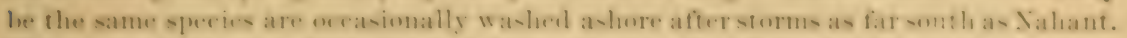

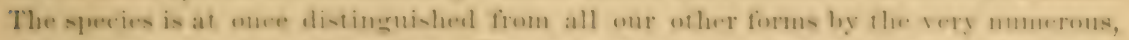

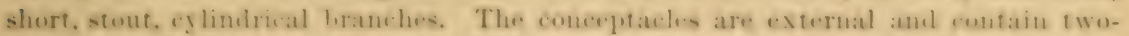
parted spores, whele may possilily be later fomp-parted, althongh in the flecimens we

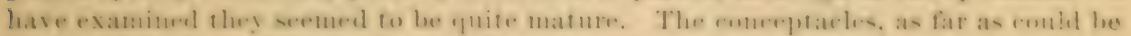
matle out, had ne distimet erifice, and were very umele tlattened extermally.

\section{A D D E N D A.}

\section{To follow Stilophora, page 89 :}

\section{A IRTIROCLADIA, Duly.}

Fromes olivel:rown, filiform, lranching, composed of a lange central filament formed of eylindrical cells and a series of polygonal reortical cells, which hecome smaller towards the surfiere plurilocular sporangiat moniliform, borne on branching monosiphonous filaments which form tufts on the branches.

A sua!l genus, enu-isting of a single species, whiwh has luen divided log Kiitring into

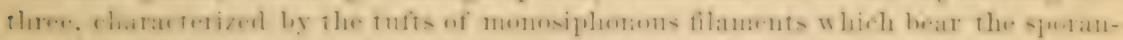

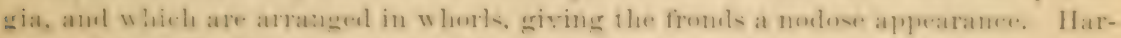

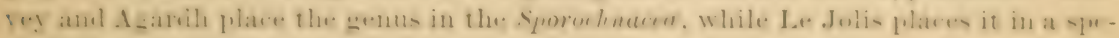
cial suborier of Pheosporece.

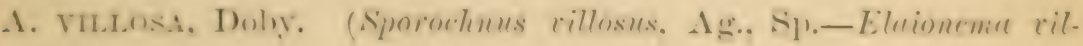
losum, Berk.)

Fromels six inclues to three feet lome, elelicately filifurm, with a perrurrent axis and usually opposite, wiolely sprealinge, 1-ב̈ oppositely pinnate hranches: fruetiferous tilaments hyssoid, in clense penicillate tufts which form irregular whorls: plurilocular sporangia moniliform, (anmposed of mumerous cells, about 1.5-z0 in a row, generally secound on the liranclues of fructiferous filament: milocular sporangia?

Washerl ashore at Falmouth Heights, Mass.. Mr. F. T. Collius : Cape Fear.

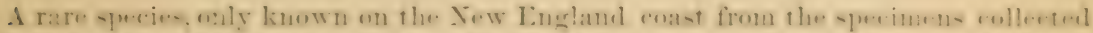

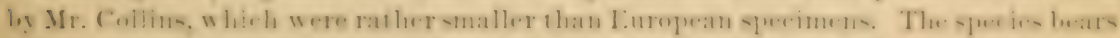

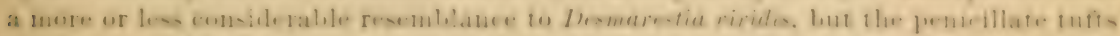

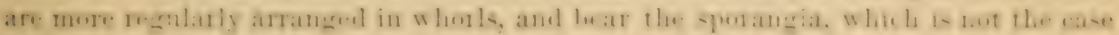
in the genus Desmarestia.

\section{To follow Lynglya, page 34:}

\section{STMPLOCA, Kiitz.}

Filaments as in L.ynglyga, but adleremg to one another in fascoleles.

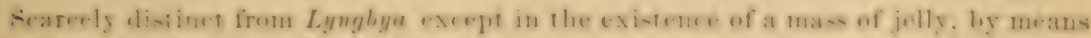

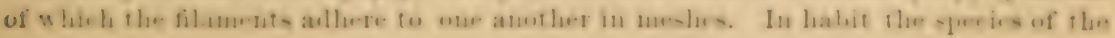


present genus resemble the species of Calothrix rather than Lyngbya, but the filaments are not prolonged in a hair-like extremity as in the first-named genus.

\section{S. FASCICULATA, Kütz.}

Filaments a quarter to half an inch high, united in tooth-like masses from a gelatinous base, .009-12mm broad, sheaths thin, cells broader than long.

On rocks between tide-marks. Newport, R. I. ; Europe.

Table of comparative distribution of New England species.

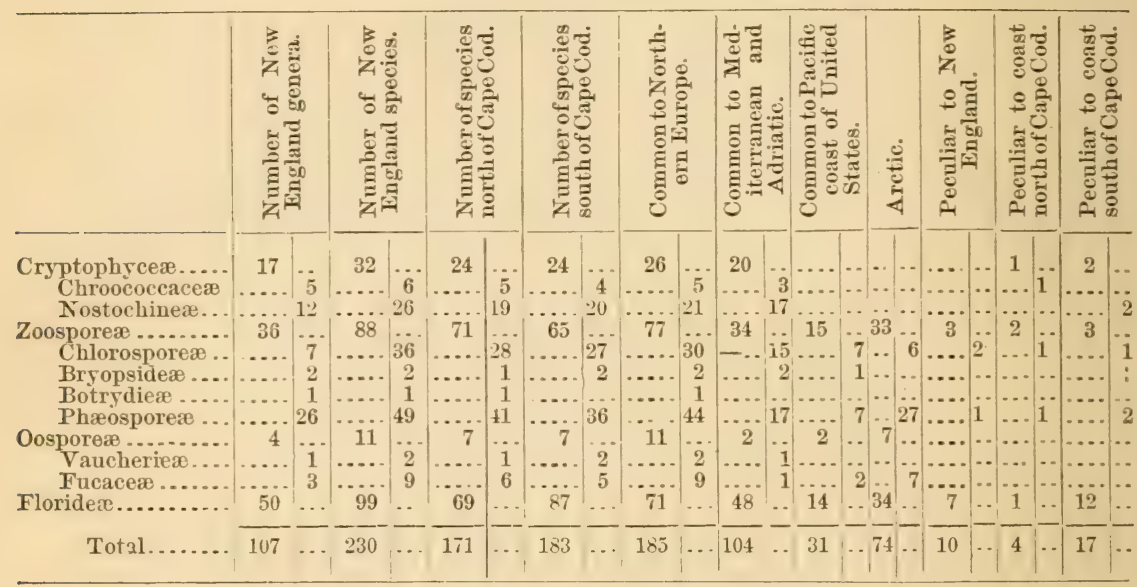

Besides the genera and species, enumerated above, there are 4 genera and 10 species described, but not considered to be sufficiently well known. If these are counted, the total number of genera is 111, and 240 species. The comparison with Mediterranean and Adriatic species is imperfect, because there is no complete list of the algæ of those seas, and our Pacific const has not as yet been sufficiently well explored to make it possible to give approximately the number of our species found there. In the table the species marked peculiar to New England are those which extend along our whoie coast, those of more limited range being kept distinct. The table shows plainly the general fact that the total number of species increases as one goes southward, and that the increase is mainly due to the relative increase in number of the Floridece. It also shows the close resemblance of our marine flora to that of Northern Europe, and although the number of species common to Arctic waters is not large, as far as the numbers themselves are concerned, yet, if we consider the absolutely small total of species found in Aretic regions, the number of species common to our coast is relatively very large. The general joverty of our florn may be seen in comparing the number of genera and species found in New England with the number of species and genera in Harrey's Phjcologia Britannica and Le Jolis's Listo des Algues Marines de Cherbourg. The number given by Harvey is 110 genera and 388 species; that given by Le Jolis is 137 genera and 316 species. The Phycologia was published in 1816-51, and Le Jolis 's Liste in 1863. In both works, more especially in the Phycologia, a number of species which we have in the present article united were kept distinct; but as additional species have been discovered since the appearance of the two works above named, the total number of species is not probably much less, or may eren be greater, than the figures given by Harrey and Le Jolis. In Phycex Scandinaricæ Marine, published in 18.50, Areschoug describes 68 genera and 175 species. Since that date numerous additions have ben made to the Scandinarian marine flora, and the total number of species is probably not far from that of the species of our own coast. 


\section{ARTIFICIAL KEY TO GENERA.}

Sorm:-The fillowing key is intended to enable persons who are not at all acruaninter with wur sea-wevels to ascertain with a partial degree of accuracy the genera to which specimens which they may collect are to be referrel. For this purpose the characters used are, as far as pusilhle, those which ean he seen by the naked eye, but, as in many cases, the grenerie distinetions alssolutely depend on microscopie characters, one must not expect to lwe al, to recognize all of our forms without making a more or less carw. ful microseopical examination, especially in the case of the Cryptophygen and I'houspored. It should of course be understood that the key is entirely artitieial, and does not represent the true botanical relations of our genera ; since in many cases the characters refer only to species of our Atlantie coast and would mislead a stulent having a specimen from other waters.

1. Color bluish or purplish green, ${ }^{*}$ alge of small size, usually more or less gelatinous ........................... (Crytophycex $) \quad 5$

2. Color grass green ................................ 18

3. Color from yellowish brown to olive green or nearly black..... 26

4. Color red or redlish purple, rarely blackish, in fading becoming at times greenish ............................ Floridece $) 48$

5. Cells arranged in filaments ........................ 9

Cells in colonies, but not forming filaments .............. 6

6. Cells grouped in twos or some multiple of two............ $i$

Cells sulitary, not adherent in twos ................... s

7. Groups free, not united with oue another by a gelatinous envelope.

Chroococeus.

Groups united by a gelatinous substance so as to form irregularlyshaped colonies............................. (ilaocapsu.

Groups united by a gelatinous substance so as to form colonies of a

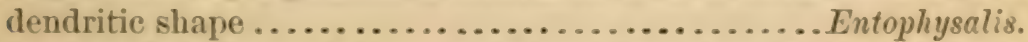

8. Cells imbedded in a gelatinous substance, forming colonies of indefinite shape ................................ Polycystis.

Cells imbedded in a gelatinous mass, which forms at first ovoidal and afterwards net-shaped colonies................ Clathrocystis.

9. Filaments ending in a hyaline hair................. 16

Filaments not ending in a hair.................... 10

10. Filaments provided with heterocysts $+\ldots \ldots \ldots \ldots \ldots \ldots \ldots \ldots . \ldots \ldots$

Filaments destitute of heterocysts ................. 12

11. Filaments with a thin gelatinous sheath, spores not adjacent to the

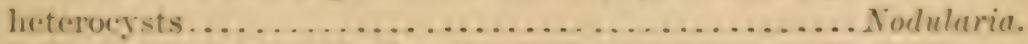

- One marine species of Clathrogystis and the grenus lieggiaton are exceptions. The former is pinkish, and covers the mud and al gas letween ticle-narks with a very fine gelatimus film. The speries of fieggiaten are whitish to the nahed eye, and form rery deluate films over decaying algie.

t Vid. page 11. 
Filaments without a gelatinous sheath, spores next to the hetero-

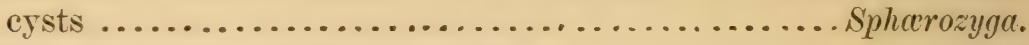

12. Filaments with a gelatinous sheath ................. 15 Filaments without a gelatinous sheath................. 13

13. Filaments spirally twisted...................... Spirulina. Filaments not spirally twisted . ...................... 14

14. Cells bluish or purplish green .................. Oscillaria. Cells colorless or containing opaque granules.......... Beggiatoa.

15. Filaments free..................................... Filaments adherent in meshes.................... Symploca. Filaments united in bundles and surrounded by a general gelatinous

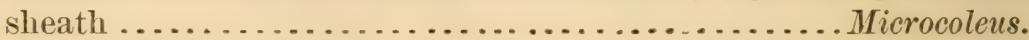

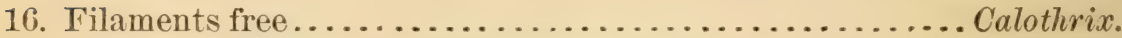
Filaments imbedded in a dense mass of jelly .............. 17

17. Filaments nearly parallel, fronds forming a thin expansion... Isactis. Filaments diverging from the base of the hemispherical or somewhat flattened fronds ........................... Rivularia. Filaments simple at the surface and forking in the interior of the vesicular fronds ............................... Hactis.

18. Fronds unicellular ............................. 19

Fronds multicellular .............................. 20

19. Cells small, ovoidal, prolongerl into a long, root-like process at the

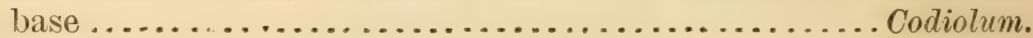
Cells large, filamentons, pinnately branching ........... Bryopsis. Cells large, with few, erect, alternate branches, some of which swell at the end and bear numerous spores................ Derbesia. Cells very long, cylindrical, with irregular or subdichotomous branches, spores large, solitary, in special lateral or terminal cells.

Vaucheria.

20. Fronds membranaceous ........................... 21

Fronds filamentous ............................. 22

21. Fronds formed of a single layer of cells.... ......... Monostroma. Fronds composed of two layers of cells, which in some cases separate so as to form tubular fronds .................. Ulva.

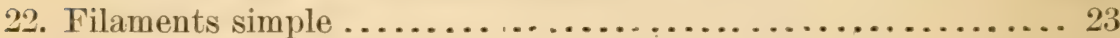

Filaments branching............................ 24

23. Small algæ, filaments soft and flaceid.............. Ulothrix. Rather coarse algæ, filaments more or less rigid, often twisted to-

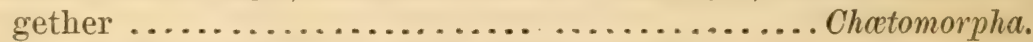

24. Some of the cells bearing long, hyaline hairs......... Bulbocoleon.

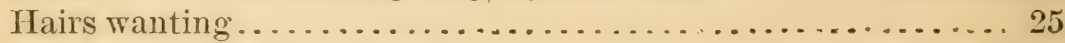

25 Branches small and root-like.................. Rhizoclonium.

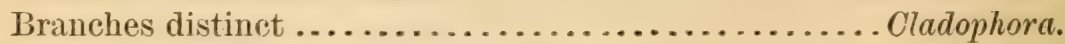

26. Fronds irregularly globose, hollow, gelatinous....... Leathesia. Fronds forming crusts or expanded pellicles............ 27 
Fromels small, tufted, composed of a dense basal portion and an outer portion composed of free filaments.............. 2s

Fronds tubular, unbranched . . . . . . . . . . . . . . . . . 29

Fronds filamentous ............................. 31

Fronds memluranaceous, expanded ................ 41

27. Fromels densely parenchymatous throughout, fruit in external

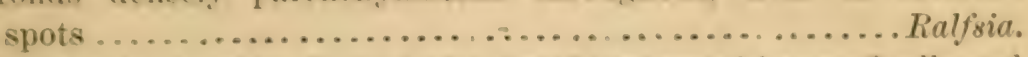

Fromels minute, thin, formed of a basal horizontal layer of cells and short rertical tilaments, hetween which the sporangia are borne.

Myrionema.

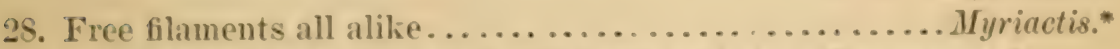

Free filaments of two linds, ome short and the other exserted.

Elochisten.

29. Fronds simple, hollow throughout, substance thin . . . . . . . . 30

Fromls simple, cylindrical, somewhat cartilaginons, with numerous

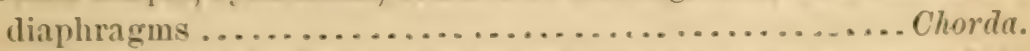

Fronds branching, substance thin, sporangia large, arranged in

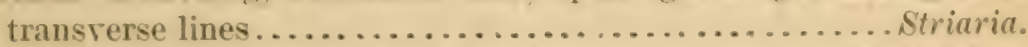

:30. Sporangia densely covering the surdice . . . . . . . . . scytosiphom.

Sporangia exterual in seattered spots.............. sperococeus.

31. Fromels capillary, hranching, formed of single rows of cells (mono-

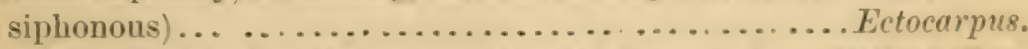

Fromds cylindrical, solid or occasionally becoming partially hollow

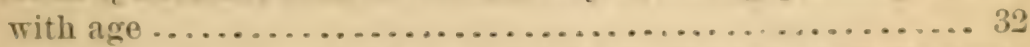

3.3. Fonds slimy, composed of an axial layer of elongaterl filaments and a distinct cortical layer of short, horizontal fllaments . . . 33

Fronds composed of elongated internal cells, which become smaller and polygonal at the surface . . . . . . . . . . . . . . . 35

Fronds, at least in the younger portions, formed of cells of nearly uniform lengrth, arrangerl in transverse bands, without any joroper

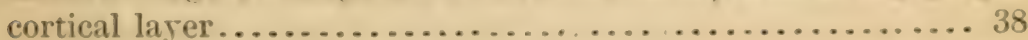

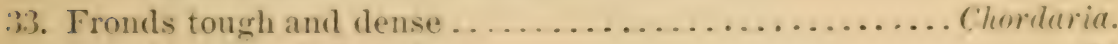

Fronds soft and tlaceid ........................... 34

34. Outer cells of cortex producing plurilocular sporangia . C'asta!nea.

Outer cells of cortex not producing plurilocular sporangiat. Mesogloide.

3.5. Fronds traversed by a central filament formed of large cylindrical

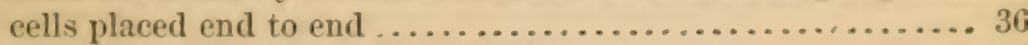

Fronds destitute of distinct axile filament ............. 37

36. Sporangia in branching, monosiphonous filaments. which form tufted whorls on the hranches. .................. Arthrocladia.

Sporangia inconspicuous, formed from the cortical cel!s. Mesmarestia. 37. Sporangia globose, prominent in the cortieal layer ... Thetyosiphom.

- When reference is male in Myriartis and the followinge gemera of Pluensporea to free external tilaments, it shomlil be underatool that muly tilaments whome cells contain coloring matter are meant, and that un acenum is to be tahen of the mumerous hyaline

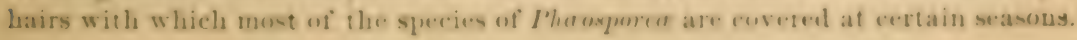


Sporangia at the base of filaments, which form scattered external tufts. Stilophora.

38. Fronds minute, ending in a hyaline hair, monosiphonous below, densely beset above with rery short brauches, between which are the sporangia............................ Myriotrichia. Fronds ending in a large, single cell, the cells of the lower part giving off descending filaments, which become interworen and form a false cortex........................... 39

39. Rhizoidal filaments few and limited to the base of the plant, branching, irregularly pinnate....................... Sphacelaria. Rhizoidal filaments numerous..................... 40

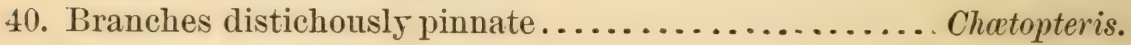

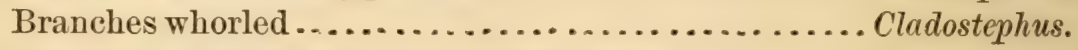

41. Fronds simple or occasionally proliferous................ 42 Fronds branching.............................. 47

42. Midrib present................................ 43

Midrib wanting................................. 44

43. Fronds stipitate, perforated with numerous holes......... Agarum. Fronds entire, with a few separate leaflets on the stipe below the

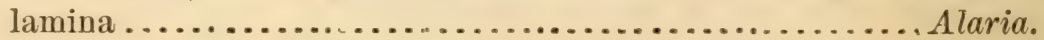

44. Fronds thin, subsessile.......................... 45 Fronds thick and coriaceous, distinctly stipitate.......... 46

45. Sporangia densely covering the surface of frond.......... Phyllitis. Sporangia external in scattered spots...............Punctaria.

46. Cryptostomata present, fronds attached by short, nearly simple rhizoids................................ Saccorhiza.

Cryptostomata wanting, fronds attached by prominent, branching

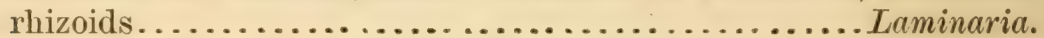

4i. Fronds without distinction of midrib and lamina, fruit borne on short lateral branches........................ Ascophyllum. Blade distinct from the midrib, bladders borne in the laminæ,

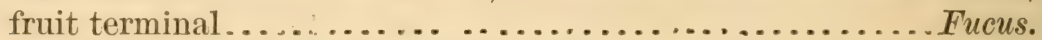
Bladders and fruit borne on special stalks........... Sargassum.

48. Fronds calcareous ............................... 49

Fronds not calcareous........................... 50

49. Fronds erect, filiform, articulated ................. Corallina. Fronds thin, horizontally expanded................. Melobesia. Fronds thick, horizontally expanded, but rising at intervals in irregular protuberances.................... Lithothamnion.

50. Fronds horizontally expanded, crustaceous or membranaceous.. 51 Fronds erect or umbilicate .......................... 52

51. Fronds parenchymatous, spores in external warts.....Peyssonnelia. Fronds parenchymatous, spores in carities sunk in the

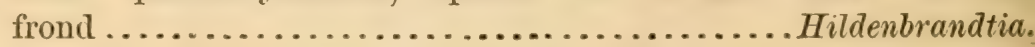


Fronds parenchymatous below, but above formed of loosely united filaments, tetraspores formed in the filaments ........ Petrocelis.

52. Fronds tubular.................................. 53

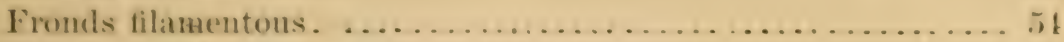

Fronds membranaceous ........................... is

53. Fromels eartilaginous, hollow throughout, rigid, proliferons, tetraspores cruciate ......................... Hulosaccion.

Fronds slender, much contracted at the joints, but without diaphragms, tetraspores tripartite in depressed carities.. Lomenturia. Fronds slemler, nodose, with diaphragms at the nodes, tetraspores tripartite in the cortical layer.................... C'hampiu.

54. Fronds monesiphonous, without proper cortex ... . . . . . 55

Fronds with distinct axial and cortical layers ............. 6:

5. Fronds monosiphonous throughout............... 56

Fronds at first monosiphonous, becoming polysiphonous above, spores formed by divisions of any of the cells, filaments simple, gelatinous, dark purple..................... Bangia.

Fronds monosiphonous abore, but below with a false cortex formed by descending filaments given oft' from the cells..........60

Fronds formed of large cells placed end to end, with bands of smaller cells at the nodes, in some cases the norlal cells extending in at thin layer over the internodal cells.................6 61

56. Spores (as far as known) formed directly from the contents of any of the cells.................................... 57

Spores on short pedicels, distinct, undivided ....... Trentepohlia (?).

Tetraspores and erstocarps present ................... 5s

5i. Filaments simple, forming a fine web over other algre.

Erythrotrichia.

Filaments dichotomously branching, minutely tufted. . Goniotrichum.

58. Fronds formed of prostrate filaments, from which arise erect pinnate filaments, cystocarps terminal, involucrate, spores irregularly grouped, not surrounded by a common gelatinous envelope when

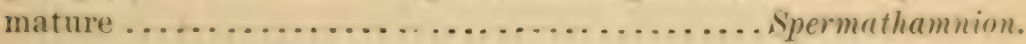

Cystocarps terminal or lateral, spores irregularly grouped at maturity, covered by a general gelatinous envelope ......... 59

59. Fronds dichotomous, formed of delicate vesicular cells, tetraspores in whorls at the joints, involucrate............... Griffithsia.

Fronds dichotomous or pinnate, tetraspores scattered on the branches, solitary or aggregated, cystocarps lateral, usually binate ...............................

Fronds with a monosiphonous axis, nearly concealed by the densely whorled branches, eystocarps terminal on short branches, tetraspores in whorls one above another on special branches. Hulurus.

60. Fronds capillary or bushy, densely branching, cortications confined to the larger branches, and evidently formed of vein-like descend. ing filaments.................... Cullithamnion, in part. 
Fronds compressed, ancipital, branches pectinate-pinnate, covered everywhere, except at the tips, by polygonal, arealated cells.

Ptilota.

61. Fronds dichotomous, tips usually incurred........... Ceramium. Fronds pinnate, main branches corticated throughout with cells arranged in transverse bands, secondary branches corticated only

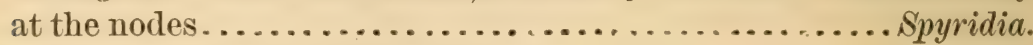

62. Fronds nearly black, substance dense ................6 63

Fronds rose-colored or purple, gelatinous or rather succulent, sometimes capillary ............................. 64

63. Fronds dichotomous, cylindrical, cartilaginous, spores borne in external flesh-colored warts......................Polyides. Fronds filiform, rigid, wiry, irregularly branching, forming dense, intricate bunches............................... Fronds small, compressed, pinnate, forming small turfs, spores borne on an axile placenta in the enlarged terminal branches.. Gelidium.

64. Cystocarps immersed in the fronds................... 65

Cystocarps external, ovate or urceolate................. 70

65. Fronds gelatinous, composed internally of a dense mass of slender longitudinal filaments, which give off short, corymbose, lateral branches, which form the cortex.................. 66 Fronds succulent, consisting of an internal layer of slender longitudinal filaments and a cortex composed of roundish polygonal cells, which become smaller towards the surface..........69 69

66. Spores arranged in regular radiating lines ............ 67

Spores in an irregular mass .........................68

67. Cystocarps naked, cortical filaments free, often ending in hairs.

Nemalion.

Cystocarps surrounded by a delicate membranous sack, cortical filaments ending in large hyaline cells, which are adherent to one an-

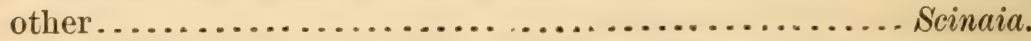

68. Fronds dichotomous, subcompressed, central filaments fine and numerous ................................... . . . Fronds filiform, pinnate, central filaments few, rather large.

Gloiosiphonia.

69. Spores arranged in groups around a central placenta.... Rhabdonia. Spores grouped in several irregular masses in the interior of the

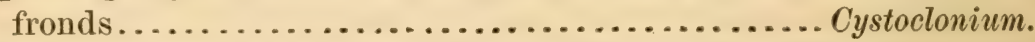

70. Fronds traversed by a distinct central filament or siphon ..... 72 Fronds without a distinct central filament ............... 71

71. Fronds succulent, brownish purple, cylindrical, beset with subulate branchlets, apices generally hooked, tetraspores zonate.. Нурпеа. Fronds red, somewhat rigid, filiform, tetraspores cruciate.

Cordylecladia.

72. Branches much contracted at base............... Chondriopsis. Branches not contracted at base ..................... 73 
73. Fronds long, eylindrieal, densely clothed with lake-red hairs.. Inesya. Fronds purple or dark red, oceasionally blackish, superficial cells either throughout or at least in the young branches arranged in transverse bands ............................. 74

Fronds dark reel, much branched, rather robust, superficial cells small, irregularly placed .................... Thodomele.

74. Tetraspores borne in the younger branches ......... Polysiphonin. Tetraspores borne in swollen, pod-like branches (stichidial).

Bostrychia.

75. Fronds cartilaginous, dense, spores immersed in the sulsstance of

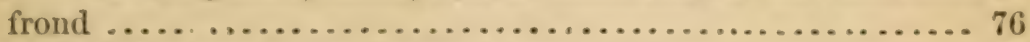

Fronds delicate or somewhat coriaceous ............... 79

Fronds gelatinous, livid purple, composed of a single layer of cells, spores in marginal bands or spots ................ Porphyra.

76. Fronds formed internally of numerous anastomosnig filaments which divide corymbosely at the surface $\ldots \ldots \ldots \ldots \ldots \ldots \ldots . . \ldots$

Fronds formed of roundish angular cells throughout ........ is

77. Fronds plane or slightly channelled ............... Chondrus.

Fronds beset with small papille, in which the spores are borne.

Gigartina.

78. Fronds with a prominent stipe, which passes into a proliferous lamina, eystocarps external, globose .............. I'hyllophora. Fronds linear, regularly dichotomous, cystocarps immersed.

Gymnogongrus.

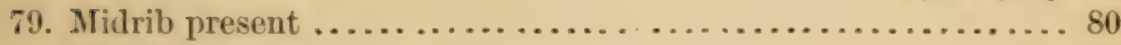

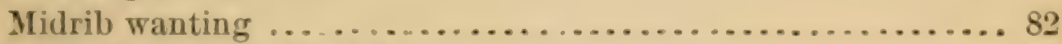

S0. Fronds rosy red, leaf-like........................ 81

Fronds dark brownish purple, narrow, dentate, midrib scarcely dis-

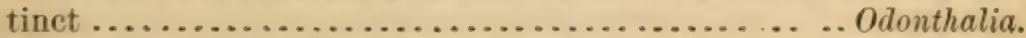

81. Tetraspores in spots on the fronds, lateral reins usually present.

Delesseria.

Lateral reins wanting, tetraspores in thickened portions of the frouds ................................... Grinnellia.

82. Fronds narrow, much divided.................... 84

Fronds palmately or dichotomonsly divided .............. 83

S3. Fronds deep red, broadly palmate, margins proliferous, tetraspores

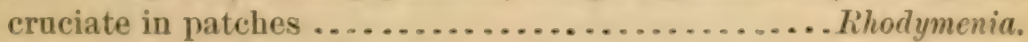

Fronds dark red, margins ciliate, tetraspores zonate.. Rhodophyllis. Fronds dark purple, deeply divided, tetraspores scattered, cruciate.

Gracilaria.

84. Branches alternately secund in threes or fours, the lowest undivided and spine-like, the rest pinnate............... Plocrmium. Fronds subtlabellate, upper divisions divarieately toothed. Euthora. 


\section{LIST OF PRINCIPAL WORKS CONSULTED.}

Agardi, C. A. Species Algarum rite cognitæ. Gryphiswald, Vol. I, 1821; Vol. II. 1828.

- Systema Algarum. Lund, 1824.

- Icones Algarum Europæarum. Leipsic, 1828-'35.

- Icones Algarum Ineditæ. Editio nova. Lund, 1846.

AgARdH, J. G. Algæ Maris Mediterranei et Adriatici. Paris, 1842

- Species, Genera, et Ordines Algarum. Vols. I, II. Lund, 1848-'63.

- Bidrag till kïnnedomen af Spetsbergens alger. Kongl. Svenska Vetensk. Akad. Handl. Stockholm, 1867.

Tillägg till föregaende afhandling. Loc. cit., 1868.

De Laminarieis symbolas offert J. G. Agardh. Universitets Arsskrift, Vol.

IV. Lund, $186 \%$.

- Bidrag till kïnnedomen af Grönlands Lamineer och Fucıceer. Kongl. Svensk» Vetensk. Akad. Handl. Stockholm, 1872.

- Bidrag till Florideernes systematik. Universitets Arsskrift, Vol. VIII. Lund, 1871.

- Epicrisis Floridearum. Contin. Spec, Gen, et Ord. Alg. Lund, 1876.

Ambrons, H. Ueber einige Fälle von Bilateralität bei den Florideen. Bot. Zeit., 1880.

Ardissone, F. Prospetto delle Ceramiee Italiche. Pesaro, 1867.

- Le Floridee Italiche. Vols. I, II, fasc. 1-3. Milan, 1874-'78.

Areschovg, J. E. Phyceæ Scandinavicæ Marinæ. Upsala, 1850.

- Observationes Phycologicæ. Parts I-III. Nova Acta Rog. Soc. Upsala, $1866-75$.

— Om de skandinaviska algformer, som äro närmast beslägtade med Dictyosiphon foniculaceus eller kunna med denna lättast förblandas. Bot. Notis. Lund, 1873.

- De copulatione microzoosporarum Enteromorpha Compressa. Bot. Notis. Lund, 1876.

- De algis nonnullis Maris Baltici et Bahusiensis. Bot. Notis. Lund, 1876.

Ashmead, S. Remarks on a collection of marine algæ. Proc. Acad. Nat. Sci., Vol.

VI. Philadelphia, 1854.

- Marine alga from Key West. Loc. cit., Vol. IX, 1857.

- Remarks on Griffithsia tenuis. Loc. cit., Vol. X, 1858.

- Enumeration of the Aretic plants collected by Dr. I. S. Hayes in his exploration of Sunith's Sound, between parallels $78^{\circ}$ and $82^{\circ}$, during the months of July, August, and beginning of September, 1861. Loc. cit., Vol. XV, 1863.

Bailey, J. W. Notes on the algre of the United States. Am. Jouru. Sci., 1847.

- Continuation of the list of localities of algæ in the United States. Loc. cit., 1848.

Bailey, J. W., and Harvey, W. H. United States Exploring Expedition during the jears 1838-'42, under the command of Charles Wilkes, U. S. N. Algx. Philadelphia, 1862.

Berkeley, M. J. Gleanings of British Algx; being an appendix to the Supplement to English Botany. London, 1833.

Bertiold, G. Zur Kenntniss der Siphoneen und Bangiaceen. Mittheil. aus der zoolog. Station zu Neapel, Vol. II, 1880.

Bornet, E., and Thuret, G. Recherches sur la fécondation des Floridées. Ann. Sci. Nat., S-r. 5, Vol. VII. Paris, 1867. 
Borset, E., and Tutret, (i. Notes Algologiques: recueil diobservations sur les algues. Fasc. 1. Paris, 1876.

C.tudes Phycologriques: analyse d'algues marines. Paris, 1-F?.

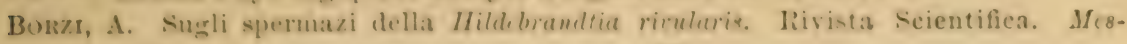
sina, 1880. Rev. Bot. Centralblatt., No. 16, 1880.

Bratx, A. Algarum Cnicellularum Cernera Nova et Minus Cognita. Leipsie, 1455.

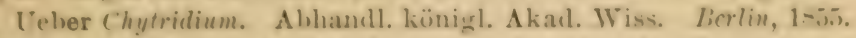

Castacise, L. Catalogue des Planteg qui croissent naturellement aux Environs do Marseille. Aix, 1845. Supplement, 1851.

Conv, F. Felver einige Algen aus Helgolond. Beitrïge zur näleren Renntniss und Verbreitung der Algen. Ed. L. Rahenhorst. Leipsic, 1غ65.

- Teber parasitische Algen. Beiträge zur Biologie der I'ilanzen, Vol. I, Part II. Breslau, $18 \% 2$.

C Untersuchungen iiber Bacterien. Loc. cit., Tart III. Breslau, 1-i5.

Const, M. Sur la reproduction des algnes marines. Comptes-liendus. Puria, 1079.

Cramer, Cali.. l'hysiologiseh-systematische tontersuchungen iiher die Ceramiaceen. Denkschrift schweiz. naturf. Gesell. Zürich, 1863.

Crotax, H. M. and P. L. Etudes mieroseopiques sur quelyues alernes nourelles on

peu connues constituant un genre uonvean. Anu. Sci. Nat., Ser. 3, Vol. XV.
Note sur queliques algues marines nonvelles de la Rade do IBrest. Loc. cit., Ser. 4, Vol. IX.

- Notice sur le genre Hapalidium. Loc. cit., Ser. 4, Vol. XII.

- Florule du Finistère. Brest, 1867.

Cersis, M. A. Geological aud Natural Histors Survey of North Carolina. Part III, Botany: containing a catalogue of the indigenous and naturalized plants of tho state. Raleigh, 1867.

De Balix, A., and Strasibrger, E. Acetabuluria Mediterranea. Bot. Zeit., 1877.

Decaissw, J. Plantes de l'Arahie Heureuse. Archives du Museum. Puris, 1841.

Essais sur une classitication des algues et des polypiers calcifires. Ann. Sci. Nat., Ser. 2, Vol. XVI, 1842.

Decaisie, J., and Tuliet, G. Recherches sur les anthéridies et les apores do quelques Fueus. Ann. Sci. Nat., Ser. 3, Vol. III. I'aris, 1-45.

DrRbis, A., and Solizr, A. J. J. Mémoire sur quelyues puints de la plyysiologie des algues. Comptes-Rendus, supplement. Paris, 1853.

Dirkı, G. Notes en a collection of alga procured in Cumlierland Somnd hy Mr. James Taylor, and remarks on Aretic species in greneral. Journ. Iroc. Linn. Soc. London, 1867.

Drulwy, L. W. British Confervæ. London, 1809.

DuDEL, A. Tlothris zonata: ihre geschlechtliche und ungreschlechtliche Fortptlanzrng. Pringsheim's Jahrbiicher, Vol. X, 1876.

DrвY, J. F. Botanicon Gallicum. Pars secuncla. I'uris, $1-30$.

EAToN, D. C. List of marine algae collected near Eastport, Maime, in Angust and September, 1-r2, in connection with the work of the U. S. Fish Comminsion, under I'rof. S. F. Bairl. Trans. Connectient Aeal. Arten and Sci., 1-i3.

Esper, E. J. C. Icones Fncorum. Nuremberg, 1797-1808.

Fariow, W. G. List of the sea-weeds or marine alga of the south coast of New Fnglanl. Rept. of $\mathrm{L}$. S. Commission of Fish and Fisheries for 1-71-72. Washington, 1873.

L List of the marine alear of the Enited States, with notes of new and imperfertly known species. Proe. Am. Araul. Arts and seci. Jiuston, 1-i5.

L List of the marine algae of the linited states. Rept. C. S. Fish Comm. for 1575. Washington, 1876.

- On some algar new to the tuited states. I'roe. Am. Acad. Arts and Sci. Boston, 1877. 
Geyler, Tri. Zur Kenntuiss der Sphacelarieen. Pringsh. Jahrb., Vol. IV, 1866.

Gmelin, S. G. Historia Fucorum. St. Pctersburg, 1768.

Goвı, C. Die Brauntange des finnischen Meerbusens. Mém. Acad. Sci. St. Petersburg, 1374.

- Die Rothtange des finnischen Meerbusens. Loc. cit., 1877.

— Die Algenflora des weissen Meeres. Loc. cit., 1878.

Goebel, K. Zur Kenntniss einiger Meeresalgen. Bot. Zeit., 1878.

Greville, R. K. Flora Edinensis. Edinburgh, 1824.

- Algæ Britannicæ. Edinburgh, 1830.

- Scottish Cryptogamic Flora. 6 vols. Edinburgh, 1823-'28

Gunder, J. E. Flora Norvegica. Pars posterior. Copenhagen, 1772.

HaLL, F. W. List of the marine algæe growing in Long Island Sound within twenty miles of New Haven. Bull. Torrey Club, Vol. VI, No. 21, 1876.

Gruxow, A. Algen der Fidschi, Tonga, und Samoa Inseln. Journ. des Museum Godeffroy, Vol. VI, 1873-'74.

Harvey, W. H. A Manual of the British Algæ. Ed. 1. London, 1841.

- Phycologia Britannica. 4 vols. London, 1846-51.

- Nereis Australis. London. 1847.

- Nereis Boreali-Americana. 3 parts and supplement. Smithsonian Contributions to Knowledge. Washington, 1852-'57.

- Phycologia Australica. 5 vols. London, 1858-'63.

- Notice of a collection of algæ made on the northwest coast of North America, chiefly at Vancourer's Island, by David Lyall, in the years 1859-'61. Journ. Proc. Linn. Soc., Vol. VI, No. 24. London, 1862.

HaUck, F. Verzeichniss der im Golfe von Triest gesammelten Meeralgen. Oesterreich. bot. Zeitschrift, 1875 et seq.

- Beiträge zur Kenntniss der adriatischen Algen. Loc. cit.

Hooker, J. D., and Harvey, W. H. The Cryptogamic Botany of the Antaretic Voyage of H. M. discovery-ships Erebus and Terror in the years 1839-'43. London, 1845.

JANCZEwski, E. Observations sur la réproduction de quelques Nostochacées. Ann. Sci. Nat., Ser. 5, Vol. XIX. Paris, 1874.

- Etudes anatomiques sur les Porphyra et sur les propagules du Sphacelaria cimhosa. Ann. Sci. Nat., Ser. 5, Vol. XVII. Paris, 1873.

- Observations sur l'accroissement du thalle des Phéosporées. Mém. Soc. Sci. Nat. Cherbourg, 1875.

- Notes sur le développement du cystocarpe dans les Floridées. Loc. cit., 1877. Jaxczewsí, E., and Rostafinski, J. Observations sur quelques algues possédant des zoospores dimorphes. Loc. cit., 1874.

KJELliax, F. R. Bidrag till kännedomen om Skandinaviens Ectocarpeer och Tilopterider. Stockholm, $\mathbf{1 8 7 2 .}$

— Om Spetsbergens marina klorofyllförande thallophyter. 2 parts. Kongl. Srenska Vet. Akad. Handl., 1875-'77.

— Bidrag till künnedomen af Kariska hafvets Algvegetation. Kongl. Vet. Akad. Förhand. Slockholm, 1877.

- Ueber Algenregionen und Algenformationen im östlichen Skagerkack. Kongl. Svenska Vet. Akad. Handl. Stockholm, 1878.

Ueber die Algenvegetation des Murmanschen Meeres an der Westküste von Nowaja Semlja und Wajgatsch. Königl. gesell. Wiss. Upsala, 1877.

Kützixg, F. T. Phycologia Generalis. Leipsic, 1843.

- Species Algarum. Leipsic, 1849.

- Tabulæ Phycologicæ. 19 vols. 1845-69.

Lamocrocx, J. V. F. Dissertation sur plusieurs espèces de Fucus peu counues ou nouvelles. Agen, 1805.

L Lssai sur les genres de la famille des Thalassiophytes non articulées. Mus. Hist. Nat. Ann. Paris, 1813.

- Histoire des polypiers coralligènes flexibles. Caen, 1816. 
La Priare. B. DE. Quelyues observations sur les productions de libe de Terre Nenro et sur quelques algues de la côte de France appartenant au genre Laminairo. Ann. Sci. Nat., Ser. 1, Vol. IV. Paris, 1824.

Flore de Terre Seure et des fles Sitint P'iorre ef Miclon. P'aris, 1-29!.

LF Jur.1s, A. Examen des espieres confondues sons le nom de Laminarin digituta, suivi de quelyues observations sur le genre Laminaria. Acad. Caes. Leop. Xora Aeta, 1855. Comptes-Rendus, 1255.

Liste des Algues Marines de Cherbourg. Paris, 1863.

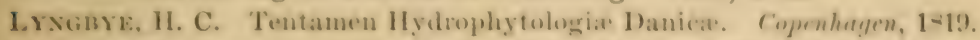

M.aciss, P. Zur morphologio der sphacelarien. Fustschrift Gesell. Naturfor. Freunde. Berlin, 1873.

_ Botanisehe Untersuchungen der Pommerania-Lxpedition. Kitl, 1-\%3.

Die bot:misehen Lrgebnisse der Nordsecfahrt von 21 Juli bis 9 September 1872. Berlin, 1874.

Mervili, J. C. Notes on the marine algie of South Carolina and Florida. Journ. Bot. London, Sept., 1875.

Mexeguxi, J. Monographia Nostochinearum Italiearum. Extr. Mem. della Accad. Scienze. Turin, 1842.

Moxtagxf, C. Sixieme centurie de plantes cellulaires nouvelles. Ann. Sci. Nat., Ser. 3, Vol. XI, 1849.

Naegeli, Carl. Die nevern Algensysteme. Ziirich, 1847.

- Gattungen einzelliger Algen. Zürich, 1849.

Beitrige zur Morphologie and Systematik der Ceramiacer. Sitzungsherichto königl. Akad. Wiss. Munich, 1861.

Nafgeli, C., and Cramfr, C. Phanzenplysiologische Cutersuchungen. Yeher dio Ceramieen. Zürich, $1-5 \%$.

Nonnstent, O. Algolorgiska smïsaker. Taucheria-stndier. Bot. Notis, 18\%-79.

OLvey, S. T. Rhode Island plants, 1-46, or addlitions to the published lists of the Providence Franklin society. Proc. Providence Franklin Suciety, Vol. I, No. 2, April, 1847 .

- Algæ Rhodiacae. Providence, 1871.

I'Eck, C. H. Twenty-second and twenty-third Annual Reports of the Regents of the Lniversity of the State of New York. Reports of the Botanist. Albany, 1869-72.

Postels, A., and RuPrecut, F. J. Illustrationes Algarum Oceani Pacifici, imprimis septentrionalis. St. Petersburg, 1840.

Pmisimm, N. Beitrïge zur Morphologie der Meeres-Algen. Abhandl. künigl. Akad. Wiss. Berlin, 1862.

- Ueher die männlichen Pflanzen und die Schwärmsporen der Gattung Iryopsis. Monatzber. Akad. Wiss. Berlin, 1871.

- Ueber den Gang der morphologischen Differenzirung in der SphacelarieenReihe. Abhandl. künigl. Akad. Wiss. Berlin, 1873.

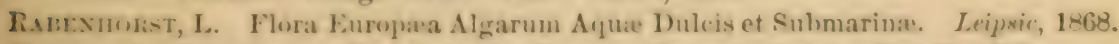

RFıke, J. Be.iträge zur Kenntnies der Tange. Pringsh. Jahrb., Yol. X. 1-iti.

- Liber das Warhsthum und die Fortpflanzung von Zanardinia colluris. Monatsber. Akad. Wiss. Berlin, 1876.

_ Ciler die Entwickelung von Phyllitis, Scytoxijhon, und Asperoceccus. Pringsh. Jahrb., Vol. XI, 1878.

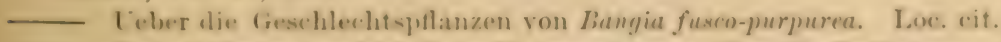

Entwicklungs-gechichtliche Lntersuchungen iiluer die Cutleriaceren des Golfs

von Neapel. Nora Acta Leop.-Carol., Vol. XL, No. 2, 187 R.

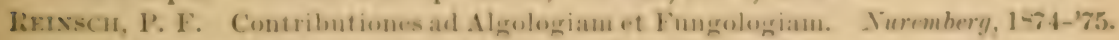

_- Ein nenes Genus der Chroolepidacew. Bot. Zeit., 1879.

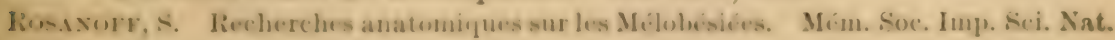
Cherbourg, 1866.

liustaflsskl, J. Beitrïge zur Kromtniss der Tange. Part I. Lefipsie, 1-r6. 
Rostafinski, J., and Woronin, M. Ueber Botrydium granulatum. Leipsic, 1877.

Roтн, A. W. Catalecta Botanica. 3 vols. Leipsic, 1797-1806.

Ruprecht, F. J. Tange des ochotskischen Meeres. In Middendorf's sibirische Reise. Vol. I, Part II. St. Petersburg, 1847.

Neue oder unvollstïndig bekannte Pflanzen aus dem nördlichen Theile des stillen Oceans. Mém. Acad. Sci. Nat. St. Pctersburg, 1852.

Schмitz, F. Untersuchungen iiber die Zellkerne der Thallophyten.

- Untersuchungen iiber die Fruchtbildung der Squamarieen. Sitzungsbericht der niederrhein. Gesell. Bonn, 1879.

Sirodot, S. Etude anatomique, organogénique et physiologique sur les algues d'eau douce de la famille des Lemaneacées. Anm. Sci. Nat., Ser. 5, Vol. XVI, 1872.

Solier, A. J. J. Mémoire sur deux algues zoosporées derant former un genre distinct, le genre Derbesia. Loc. cit., Ser. 3, Vol, VII.

Stackhouse, J. Nereis Britannica. Editio altera. Oxford, 1816.

Thuret, G. Note sur le mode de reproduction du Nostoc verrucosum. Ann. Sci. Nat., Ser. 3, Vol. II, 1842.

- Recherches sur les zoospores des algues et les anthéridies des cryptogames. 2 parts. Loc. cit., Ser. 3, Vols. XIV, XVI, 1850-'53.

_ Note sur la fécondation des Fucacées. Mém. Soc. Sci. Nat. Cherbourg, 1835.

- Note sur la synonymie des Ulia Lactuca et latissima, L., suivie de quelques remarques sur la tribu des Ulvacées. Loc. cit., 1854.

- Recherches sur la fécondation des Fucacées et les anthéridies des algues. Ann. Sci. Nat., Ser. 4, Vol. II, 1855. Seconde partie, loc. cit., Vol. III, 1855.

- Deuxième note sur la fécondation des Fucacées. Mém. Soc. Sci. Nat. Cherbourg, $185 \%$.

- Observations sur la réproduction de quelques Nostochinées. Loc. cit.

_- Essai de classification des Nostochinées. Ann. Sci. Nat., Ser. 6, Vol. I, 1875.

Turner, D. Fuci sive Plantarum Fucorum Generi a Botanis Ascriptarum Icones Descriptiones et Historia. 4 vols. London, 1808-'19.

Walz, J. Beiträge zur Morphologie und Systematik der Gattung Vaucheria. Pringsh. Jahrb., Vol. V, 1866.

Warmixg, E. Om nogle ved Danmarks Kyster levende bakterier. Videns. Meddel. Naturh. For. Copenhagen, 1876.

Weber, F., and Mohr, D. M. H. Grossbritanniens Conferven. Göttingen, 1803-'5.

Wiтtrock, V. B. Försök till en Monografi öfver Algslägtet Monostroma. Stockholm, 1872.

Wood, H. C. A contribution to the history of the fresh-water algæ of North America. Smithsonian Contributions to Knowledge, 241. Washington, 1872.

Wrigir, E. P. On a species of Rhizophydium parasitic on species of Ectocarpus, with notes on the fructification of the Ectocarpi. Trans. Royal Irish Acad., 1877.

- On the cell-structure of Griffithsia setacea, and on the development of its antheridia and tetraspores. Trans. Royal Irish Acad., 1879.

- On the formation of the so-called siphons and on the development of the tetraspores in Polysiphonia. Loc. cit.

Zaxardixi, G. Iconographia Phycologica Adriatica. Vols. I-III, Parts I-IV. Venice, $1860-{ }^{-} 76$.

\section{ALGAE EXSICCATA.}

Arescior:G, J. E. Phyceæ Extræuropææ Exsiccatæ. Fase. 1-3, Sp. 90. Cpsala, $1850-' 56$.

- Algæ Scandinavicæ Exsiccatæ. Series nova. Fasc. 1-9, Sp. 430. Tpsala, 1861-'79.

Chauvin, J. Algues de la Normandie. Fasc. 7, Sp. 175. Caen, 1827.

Crotan, H. M. and P. L. Algnes marines du Finistère. Fasc .3, Sp. 404. Brest, 1852.

Desirazì̀res, J. B. H. J. Plantes cręptogames de France. Editio I. Fasc. 27-37, Sp. 1301-1850. Lille, 1848-51. Editio II. Fasc. 1-16, Sp. 1-800. 
Fanıw, W. G., Axpresos, C. L., and F.ıтox, D. C. Algat Am. Bur. Exsiccatr. Fase. 3, Sp. 1301. Liesten, 1-i;-79.

Honexacker, R. F. Alga marina siccat:

L* Jolis, A. Algues marines de Chroburg. Sp. 1-2(11).

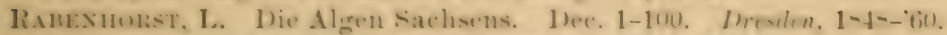

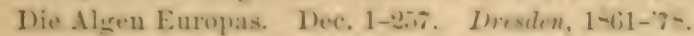

WestexdoRP, G. B., and Wat.l.Y. A. C. Herbier erpptogamique ou collection de plantes cryptoganes et agames qui eroissent en Belgique. Fase. 11, sp. 501-1400. Courtrai, 1851-'59.

Wiтmock, V. 13., aul Xonistert, O. Algar Aquar Inleis Exsiceater pracipue Scandinaviea quas aljectis algis marinis chlorophyllaceis et pligeochromaceis distribuerunt Veit Wittrock et Otto Norilsteelt. Fasc. 1-6, Sp. 300. Tparala, $157 \%-79$.

TrYat, Mrs. MarY. Algr Danmonienses. Torbay. 



\section{EXPLANATION OF PLATES.}

\section{PLATE I.}

J. H. Bluke and W. G. Farlow.

Fig. 1. Glococapsa erepidinum, Thuret. 600 diam.

2. Isactis plana, Thuret. 600 diam.

3. Spharozyga Carmichetelii, Harv, : a, heterocyst : h, h, spores. 600 diam.

4. Lyngbya majuвcu?a, Harv, 400 diam.

5. Oscillaria subuliformis, Harv. 500 diam.

6. Calothrix conferricola, Ag. : a, a, hormogunial : b, b, heeterocysts; c, cell of hostplant. 400 diann.

\section{PLATE II.}

\section{J. H. Blake and W. G. Farlore.}

Fig. 1. Hormactis Quoyi, (Ag.) Bornet: $a, a$, heterocysts. 600 diam.

2. Iiruluria atra, Roth: $a, a$, heterocysts; the cross-lines represent the gelatinous matrix. 500 diam.

3. Microcoleus chthonoplastes, Thuret: a, free trichomata projecting beyond tho ruptured sheath. 500 diam.

4. Spirulina tenuissima, Kiitz. 900 diam.

\section{PLATE III.}

\section{J. H. Blake and I. G. Farlow.}

Fig. 1. Clla Lactura, (L.) Le Jolis: a, mirrozomspores which have eseaperd from marginal cells; $b$, cells in which zoospores are forming; $c$, cells from which zoospores have escaped. 500 diam.

2. Rhizoclonium riparium, Kiitz. 20 diam.

3. Cladophora letevirens, (Dillw.) Harv. 20 diam.

\section{PLATE IV.}

\section{J. H. Blake and W. G. Farlore.}

Fig. 1. Liryopsis plumesn, (Huds.) Ag.; portion of npper division of the unicellular frond. 10 diam.

2. Vaucheria Thuretii, Woronin : $a, a$, young antheridia: $a^{\prime}$, antheridium which has dischargerl its antherozoids: $e, r$, omennia with owspores. 100 diam.

3. I'lyllitis fuxria, Kiitz; section of frond with plurilucular sporangia, a, covering the surface. 500 diam.

4. Derbesia tenuiswima, (De Nut.) Crouan: $a$, spores (zouspurangia i) nearly mature; $b, b^{\prime}$, cross-partitions forming cell at hase of sporangiun. 100 diam.

5. Puncturia plantaginea, (Roth) Grev.: transverse section of frond: a, plnrilocular sperangia with zoospores; $a$, the same when old, after the zoompores have been dischargerl and the internal cell-walls obliterated. 


\title{
PLATE V.
}

\author{
J. H. Blake and W. G. Farlow.
}

Fig. 1. Leathesia difformis, (L.) Aresch.; dissection showing a portion of cortical layer: $a, a$, unilocular sporangia; $b, b$, hairs. 400 diam.

2. Chordaria flagelliformis, Ag.; longitudinal section of outer part of frond showing cortical filaments with unilocular sporangia, $a$, and a few cells of internal layer. 500 diam.

3. Asperococcus echinatus, Grev.; transverse section of frond: $a$, unilocular sporangia ; $b$, hairs. 150 diam.

4. Stilophora rhizodes, Ag.; longitudinal section of outer part of frond showing sorus with paraphyses and unilocular sporangia. $\mathbf{j 0 0}$ diam.

6. Ralfsia verrucosa, Aresch.; vertical section of froud with a sorus containing unilocular sporangia.

6. Sphacelaria cirrhosa, (Roth) Ag.; a portion of frond with propagulum. 200 diam.

\section{PLATE VI.}

\section{J. H. Blake and W. G. Farlow.}

Fig. 1. Chorda flum, L.; transverse section of portion of a frond showing paraphyses, $b$, and unilocular sporangia, $a .200$ diam.

2. Stilophora rhizodes, Ag.; portion of sorus taken from Pl. V, Fig. 4, more highly magnified to show unilocular sporangia, $a, a^{\prime}$, and paraphyses, $b .600$ diam.

3. Ectocarpus littoralis, Lyngb., var. robustus, Farlow; plurilocular sporangia. 200 diam.

4. The same with unilocular sporangia.

5. Myrionema Leclancherii, (Chaur.) Harr.; vertical section showing plurilocular sporangia. 400 diam.

\section{PLATE VII.}

\section{J. H. Blake and W. G. Farlow.}

Fig. 1. Castagnea virescens, (Carm.) Thuret; unilocular sporangium and hair, b. 400 diam.

2. Castagnea Zosterce, (Mohr.) Thuret; transverse section of outer portion of frond showing plurilocular sporangia, $a, a^{\prime}$, and hair, $b .400$ diam.

3. Elachistea fucicola, Fries; dissection of superficial part of frond, showing unilocular sporangia, $a ; \boldsymbol{a}^{\prime}$, and colored exserted filaments, $b$. 300 diam.

\section{PLATE VIII.}

\section{J. H. Blake and W. G. Farlow.}

Fig. 1. Fucus resiculosus, L.; fructifying tip of frond: $a$, air-lladder; $b$, conceptacles. Natural size.

2. Laminaria longicruris, De la Psl.; section throngh fructiferous portion of frond showing unilocular sporangia, $a$, and paraphyses, $b .400$ diam.

\section{PLATE IX.}

\section{J. H. Blake and T. G. Farlow.}

Fig. 1. Fucus vesiculosus, L. ; section through a female conceptacle showing oospores and paraphyses. 200 diam.

2. The same; section through male conceptacle showing antheridia. 200 diam. 


\title{
PLATE $X$.
}

\author{
J. H. Blake and W. G. Farlore.
}

Fig. 1. Spyridin filamentuse, Harr.; axis with branch bearing antheridia, $a$. 200 diam.

2. Callithamnion corymbesum, Lyngh. : branch with antheridia. 200 diam.

3. Trentepehliet rirgatula, Harr, ; showing the undivided spores, $a, a$. 200 diam.

4. Ciriflithia Jernetiana, Farlow ; tip of male plant with antheridia. 400 dian.

5. The same: portion of tetrasporic plant with tetraspores, $a$, and involucre, $b$. 200 diam.

\section{PLATE XI.}

\section{J. H. Blake and W. G. Farlow.}

Fig. 1. Callithemnion Baileyi, Harr.; plant with tetraspores: a, before separation from the mother-cell; $a$, free from the mother-cell. 200 diam.

2. The same; plant bearing binate cystocarp.

3. Griffithsia Bornetiann, Farlow; plant bearing cystocarp (favella). $2(n)$ diam.

\section{PLATE XII.}

\section{J. H. Blake and W. G. Farlow.}

Fig. 1. Temalion multifitum, Ag.; dissection of outer part of the plant to show the cystocarp. 400 diam.

2. Spyridia filumentosa, Harr.: tip of female plant with a doulle cystocarp, the right-hand portion of figure representing the cystocarp and branch in section; the left-hand eystocarp being seen superficially. 400 diam.

\section{PLATE XIII.}

\section{J. H. Blake and W. G. Farlow.}

Fig. 1. Polysiphonia Olneyi, Marv.; branch with antherislim, a. 201 diam.

2, 3, and 4. Cirinnellia Americana, Harv.: Figs. 3 and 4 represent the antheridia seen from alove and in section, $a$; Fig. 2, section through a cystoearp. 400 diam.

\section{PLATE XIV.}

\section{J. H. Blake and T. G. Farlow.}

Fig. 1. Petrocelis crucnta J. Ag. ; dissection of frond showing the tetraspores, a, a. 400 diam.

2. Rhabdonia tenera. J. Ag.; trausverse section of frond showing eystocarp aud carpostome. 200 diam.

\section{PLATE XV.}

\section{J. H. Blake and W. G. Farlor.}

Fig. 1. Ilasya elegans, $\Lambda_{\mathrm{n}}$.: loranch with st ithielium hearing tet raspores. 300 diam.

2 and 5. Champia parrula, Ilars. : Fig. 5, jortion of frond bearing a cystocarp, $a$; slightly cularged ; Fig. 2, section throngh a, showing arrangement of spores, carpogenic cell, and carpostome. 400 diam.

3 and 4. Polysiphonia Harreyi, Bail. Fig. 4, hranch with cystocarp: Fig. 3, section through the same, showing spores and carpogenie coll. 400 diam. 


\section{INDEX OF GENERA AND SPECIES.}

[The synonyms and species incidentally mentioned are in italics. The larger-sized figures indicate the page where the description is given.]

\section{A.}

Acctabularia Mcditerranea L.x...........

Acroblaste Reinsch

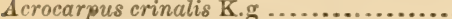
lubricus K.g......................

A garum Post. \& Rupr. fimbriatum Harr.

S glaiophyllum Americanum Mont........

Alunfuldia Frieg - - ..........

" gigartinoides Ag ................... plicata Fries ...................... 4, 148

" " v. fastigiata Post. \& Rupr......

Alaria Grev ..........................

" esculenta Grev......................

" " v. latifolia Post. \& Rupr....... Pylaii Grev

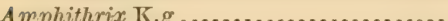

Anabaina marina Bréb ..................

Antithamnion Naeg ...................121, 122 cruciatum Naeg ..................

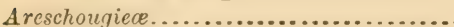

Arthrocladia Duby ...................... villosa Duby .

Ascophyllum Stack nodosum Stack....................

Asperососсев ...........................

Asperococcus L.x ....................... bullosus L.X...................... compressus Griff

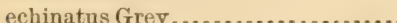
sinuosvs Bory.....................

B.

Bacillus Cohn

Bacteria

Bacterium rubesceins Lankaster - -

Balbixnia sirod

" ceramicola Chauvin................. 112, 113

" ciliaris Carm....................... elegans Chaurin ....................

fusco-purpurea Lyngb .

112

113

112

Batrachospermum Roth ...............20, 108, 116

Beggiatoa Trevisan ................... 12, 32

" alba Treves v. marina Warm........

arachnoidea Rab...................

" minima Warm......................

" mirabilis Cohn .......................

Biadder-kelp

Bonnemaisonia asparagoides $\mathbf{A} g$..........

Bornetia Thuret. 202
Page.
Bostrychia Mont ....................169, 175, 177

" rivularis Harv ................... 176

scorpioides Mont................. 176

Botrydieæ.......................13, 14, 25, 58

Botrydium granulatum (L.) Grev ........ 14, 58 gregarium Farlow................. 14, 58

Bryopsideæ.....................13, 14, 25, 59

Bryopsis L.x .......................... 59

hypnoides L.x................... 60

plumosa (Huds.) Ag .............. 14, 59

tenuissima De Not .................. 60

Bulbocoleon Pringsh..................24, 57, 69 piliferum Pringsh.................. 5y

C.

Calliblepharis ciliata K.g.............. 5, 152, 153 jubata K.g ....................... 153

Callithamnion Lyngb................21, 108, 109, $118,120,131,142$

Americanum Harv .................. 123 Baileyi Harv ...................20, 121, 127 " v. laxa Farlow................. 127

Barreri Ag.................... 124, 126

brachiatum Harv.................. 126

byssoideum Arn ...............121, 1'27, 128

"6 $\mathrm{v}$, fastigiatum Harv .......... 128

" $v$, unilaterale Harv ............ 128

" ". Waltersii Harv ........... 128

corymbosum Lyngb.........121, 123, 128, 129

v. secundatum Harv.......... 128

cruciatum Ag.................. 122

Daviesii Harv..................... 109

Dietziæ Hooper ..................127, 129

floccosum $\mathrm{Ag}$....................12:, 125

graniferum Menegh ............... 123

" Labradorense Reinsch ............. 125

' luxurians Ner. Am. Bor... ......... 10 ?

" polyspermum Ag ................. 123

plumula Lyngb ................... 124

roseum Harv .................... 125

Pylaisæi Mont .................. 5, 123, 124

Rothii Lyngb ...................121, 170

secundatum Lyngb................ 109

seirospermum Harv................ 129

tenue Harv ........................ 130

tetragonum $\mathrm{Ag}$.................126, 127

Tocwottoniensis Harv ............ 130

versicolor Ag....................... 129

" v. seirospermum Ag.......... 129

virgatulum Harv.................. 109

Callophyllis K.g......................... 144, 153

cristata K.g.................... 153 
Page.

Callophyllis leeiniata K.g

Caloglosea Ag

Ieprieurii $\mathbf{A g}_{\mathrm{g}} . . . . . . . . . . . . . . . . .$.

Calosiphonia Crousn .

Calothrix (Ag.) Thuret.

confervicola $\Delta \mathrm{g} . . . . . . . . . . . . . . .$.

- erustacea Born. \& Thuret..........

- hylneviles Harv.

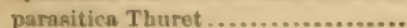

parietina Thuret....................

, puirinata $\Delta g$......................

scopulorum $\mathrm{Ag}$

riripara Harv.

" sphorephora Kjellm

Castagnea Thuret

.. vireven Thuret

"Zosterw Thuret

86

Ceramieso ._............25, 107, 1 1 9, 139, 141, 142

Ceramium Lyngb........................131, 134

". botryocarpum Harv .................

. Capri-Cornu (Reinsch) ...............

" circinnatum K.g ....................

135

" corgulusum $\mathrm{Ag} \ldots \ldots \ldots \ldots \ldots \ldots . . . .$.

. Deslongchomprit Forlow -

. diaphanum Roth..................136, 139

. fastigiatum Harv ................. 137, 138

.. Honperi Harv...................... 76, 136

nodorum Phyc. Brit................ 138

rubrum $\mathrm{Ag}$.....................4, 135, 148

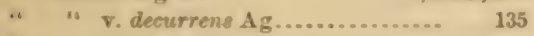

". "

. "

.. $\quad$ o v. squarrosum Harv .......... 135

strictum Harv .................... 136, 139

tenuissimum $\mathrm{Ag}$.................137, 135

". arachnoideum Ag......... 138

*. patentissimum Harv ........ 135

Foungii Farlow................... 138

C'hrtomorphn K.g..................... 45, 46

.4 serea (Dillw.) K.g ................. 46

" herbacea K.g.......................

“. Linum (Flor. Dan.) K.g .............

“ longiarticulata Harv ...............

. melagonium (Web. \& Mohr) K.g...

* Olneyi Harv

. Picquotiana (Mont) K.g...........

, rutoria (Berk.) Harv.................

" tortuosa Harv........................

tomilosa Zan

Chatopteris K.g

75,77

$5,7 \boldsymbol{7}$

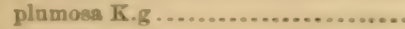

" equamulosa K.g.

Champia Harv.

$140,154,15.5$

parvula Harv

156

Chantransia Anct.

108

corymbifera Thuret.

108,109

" eplorescens Tharet

109

it investiens Lenor ........................

Characea

108

Characinm A. Br.......................

Chlorodesmis raucheriaformis Harv

Chlorospermece

$10,12,40$

Chlorosporese ....................... 13, 25, 10, 44

Chlorozoosporea, see Chlorosporea.
Page.

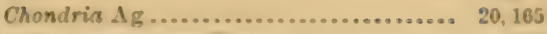

atripurpuria IIary ............. 167

Baileyana Harv .................. 4, 6, 160

litturalis IIarv..................... 167

nidificat Il.urv .................. 167

sedifolia Harv ................... 160

striolata Ag...................... 160

striclata Farlow................... 168

tenuissima $\Delta \mathrm{g}$................... 4, 166

Chondriopsis Ag ..................164, 165, 168

atmpurpurea $\mathrm{Ag}$................ 16 8

v. fasciculata Farlow ......... 168

dasyphila Ag.................... $\mathbf{1 6 6}$

v. sedifulia $\mathbf{A g} \ldots \ldots \ldots \ldots . . . .166$

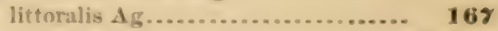

tenuissima $\Delta g$.................166, 167

v. Baileyana Farlow ......... 166

Chond rosiphon, uncinatus K.g ........... 154

Choudrus Stack ......................146. 145 crispus (L.) Stack ..........4, 9, 146, 148, 150

Norregicus Lyngb.................. 140

Chorda stark....................... 91

filum L........................... 91

v. lomentaria K.g ............

lomentaria Ljngb .............. 15,63

tomentosa Lyngb ................... 91

Chordariacere ......................... 61

Chordaries ......................16, 17, \$3, 116

Chordaria Ag ........................ \$ 83

divaricata Ag ................ 5, 8, 57,83,84

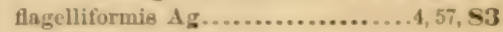

จ. densa Farlow.............. \$4

v. hippuroides $\mathrm{Ag}$........... 6 6

Choreocolax Reinseh ...................109, 110

Americanus Reinsch............... 110

mirabilis Reinsch .................. 110

Polysiphonia Reinsch............. 110

Rabenhorsti Reinsch............. 110

tumidus Reinsch.................. 110

Chroococeacer ........................11, 25, 26

Chroococcus Naeg..................... 27

"turgidus Naeg ................... 27

Chroulequider ........................ 57

Chrysymenia ........................... 149, 154

rosea Harv...................... 15.5

Chthonoblastus anguiformis Rab........ 33

"Lyngbei K.g ..................... 83

"repens K.g....................... 34

Chylocladia Grev....................... 154

Baileyana Harv .................. 154

rosea Harv......................... 155

uncinala $\mathrm{Ag}$...................... 154, 155

Chytridium A. Br ....................15, 68, 73

plumula Cohn .................... 123

sphacelarum Kny ................. 76

Ciliaria fusca Itupr .................... 152

Cladophora K.g ...................... 50

albida (Huds.) K.g .............51, 52,55

$\operatorname{arcta}($ Dillw.) .................... 50

centralis A uct. .................... 51

erystallina Isoth.................... \$3

diffusa Harv .................... $\quad B_{3}$

expanas K.g.................... $5 \mathbf{5}$

flavescen. K.R ................... 50

Dexuosa (Griff.) Harv ............ \$. \$ 
Cladophora fracta (Fl. Dan.) K.g

Page.

56 glaucescens (Griff.) Harv..........52, 54, 55

" . pectinella Harv ............. gracilis (Griff.) K.g .................

" v. expansa Farlow.............

" $v$. tenuis Thuret.

Hutchinsiæ (Dillw.) K.g ............

lætevirens (Dillw.) Harv............

lanosa (Roth) K.g.................

' v. uncialis Thuret .............

Magdalenæ Harv .................

Morrisiæ Harv ........................

pseudo-sericea Crouan

refracta (Roth) Aresch

Rudolphiana Ag ...................

rapestris (L.) K.g

sericea (Huds.) ...

"vadorum A resch

vaucheriaformis Ag................

Cladosiphon

Cladostephus Ag.

$15,75,7$

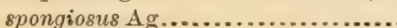

"verticillatus Ag...................

" " " spongiosus Farlow.........

Clathrocystis Henfrey.

ceruginosa Henfrey.................

roseo-persicina Cohn...............

Codiolum A. Br ........................

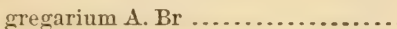

Nordenskioldianum Kjellm .........

Codium Stack ...........................

tomentosum Stack..................

Coilonema Aresch ........................

Coleochæte Bréb ........................

Conferva cerea Dillw.

arenicola Berk .....................

arenosa Crouan ......................

brachiata Engl. Bot

collabens Harv .....................

implexa Aresch

implexa Harv.

Linum Crouan.....................

majuscula Dillw ...................

melogonium Web. \& Mohr ..........

penicilliformis Roth.

Picquotiana Mont...................

tortuosa Harv......................

Youngana Harv....................

Corallinøæ ............................25, 17\%

Corallina L.x ........................178, 179

officinalis $\mathrm{L}$....................... 4, 179

squamata Ell....................... 179

Conjugatece.............................. 98

Cordylecladia Ag ......................149, 151

Huntii Harv ...................... 151

Corticularia K.g........................

Corynephora marina $\mathrm{Ag}$.................

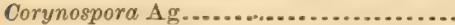

Cruoria pellita Harv.

Oruoriopsis cruciata Dufour..............

Cryptococeus roseus K.g ..................

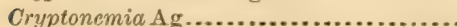

Cryptonemieæ................25, 120, 140, 142, 149

Cryptophyceæ ....................8, 11, 25, 26

Cryptopleuro, Americana K.g............ 161
7,90

Cutlerioce

Cylindrospermum Carmichaelii K.g ...... $\quad 30$ polysporum K.g................... 31

Cystoclonium K.g .................... 147 purpurascens K.g........4, 110, 147, 148, 159 v. cirrhosa Harv ............. 147

Cystoseirea. .......................8, 81, 82, 99

Cystoseira myrica, Ag................... $\quad 82$

D.

Dasya Ag ............................164, 176

coccinea Ag ....................... 177

elegans Ag..............4, 6, 146, 162, 177

pedicellata C. Ag ................... 177

Dasyactis plana K.g................... $\quad 39$

Delesseria L.x......................161, 162

alata L.x....................... 5, 163

" " " angustissima Harv......... 163

"Americana Ag..................... 161

" Leprieurii Mont ................. 163

$"$ sinuosa L.X .............4, 5, 134, 154, 162

Delesseriece.......................... 161

Derbesia Sol......................... 59, 60

Lamourouxii Sol.................. 60

" "marina Sol......................... 60

" tenuissima (De Not.) Crouan........ 60

Desmarestieæ........................ 16,64

Desmarestia L.x........................ 64

" aculeata L.X ..................... 5, 65

" ligulata L.X...................... 65

" viridis L.X .....................5, 65,183

Desmiospermea ........................ 106

Dichloria viridis Grev................... $\quad 65$

Dictyosiphon Grev ..................15, 66, 84

foniculaceus Grev................. 66

"foniculaceus Aresch ................ $\quad 66$

" hippuroides Aresch .............. $\quad 5,66$

Dictyosiphoner...................... 65

Dictyotacea ....................7, 12, 61, 88, 89, 90

Dictyotece ............................ $\quad 19$

Dolichospermum polysporum Wood ...... $\quad 31$

Dorythamnion Baileyi Naeg.............. $\quad 127$ tetragonum Naeg.................. 126

Dudresnaya Bonnem ...............21, 114, 141, 160 " coccinea Ag ........................ 160 purpurifera Ag ................... 160

Dulse ..............................

Dumontieæ.......................25, 139, 142

Dumontia filiformis Grev ............... 142, 143

Durvillaea Bory ......................... 99

E.

Ectocarpacece......................... 61

Ectocarpeæ........................ 16,68

Ectocarpus Lyngb...............15, 68, 89, 121

" amphibius Harv .................... 71

"Anticostiensis Reinsch ............. $\quad 73$

" brachiatus Harv .................... 74

"Chordariæ Farlow .................. 69

confervoides Le Jolis................. 68, 71

" v. hiemalis Kjellm ............ 71,72

" v. siliculosus Kjellm .......... $7 \mathbf{1}$ 
Eetocarpus Dictzice IIary .

Durkeei IIarv

Farloteii Thuret. r. draparnalelivides Crouan ....

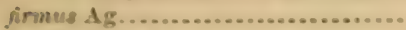
graunlosus Ag...

v. tenuis Farlow.

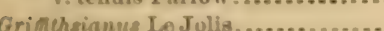

hiemalis Crouan. ......................

Hnoperi Hart......................

Iandsburgii Harv ..................

littoralis Lyngb ....................

". robustus Farlow .............

lutosus Hart .......................

Mitchelle Harv...................

yusillus Griff .......................

reptaus Crouan

spharophora Harv

tomentosus Lyngb. . . . . ..............

" viriclis Harv ......................

Eel-grass

Egregia A resch

Elachisten Duby .........................

attenuata Harv ......................

Canadensis Rupr....................

4 Maccida A resch. .......................

"s fucicola Fr.........................

" lubriea Rupr.

pulvinata Harv

scutulata Duby

Elaionema villosum Berk.

Enteromorpha compressa Auct

". intestinalis Auct.

"Grevillei Thuret.

"Linkiana Grev.

ramulosa Hart

Entonema Reinsch

Entophysalis K.g

granulosa K. $\mathrm{K}$...

Maruoliae Farlow

Errthrotrichia Aresch

ceramicola Aresch

Euactis amana K.g

" atra K.g......

". confluens K.g

" hemispharica K.

hospita K.g ........................

Lenormandiana K.g .

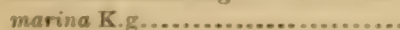

prorumpene K.g ....................

Eucallithamuion ........................

Eucheuma Ag............................

Eucladophora

Euthora $A_{g}$

$.149,153,158$ cristata $\mathbf{A} 8$

P.

Foridexo

$.11,19,25,106$

Floridea Incerteo Sedis.

104

Fucacex....................18, 25, 10, 92, 95, 99, 100

Fucodium nodorum J. $\mathbf{A g}$.

Fucus (L.) D.c.ne \& Thuret.

" agarum Turn.

bicornia De la Psl
72

72,73

70

74

71

75

75

$7: 3$

$7 \cdot 2$

$7: 2$

6,68
69

74

0, 72

71
9

15,61

6,80

81
81

80

80,81

80

80

183

43

43

41

44

44

69

29

29

112

113

38

38

38

38

38

38

2.5

158

1

Fucus canaliculatus L...

Page.

ceranoides L

cribrusus Mertens......................

distichus L..........................

evanescens Ag a

Aliformis Gmel .................. 10.2

furcatus $\mathrm{Ag}$..................... 102

microphyllus Do la Pyl............. 101

nutans L......................... 103

natans Turn ...................... 103

nodosus L....................... 18,99

pertusus Mertens ................... 90

platycarpus Farlow ................ 101

serratus L ........................ 101

vesiculusus L..............18, 100, 101, 102

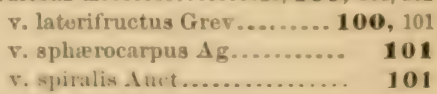

Furcellaria fastigiata L.x............... 160

G.

Gelidiens .............................25, 158

Geliclium L.x......................... 15 \%

corneum L.x..................... 7, 158

$\nabla$. crinale $\Delta$ uct ............... 158

crinale $\mathrm{Ag}$....................... 7,158

Gigartina L.x......................... 148

mamillosa Ag..................148, 149

papillata $\mathrm{Ag}$......................... 148

plicata L.x....................... 147

tenera J. Ag ...................... 159

Gigartineæ.........................25, 143, 156

Ginannia furcellata Mont............... 118

Giraudia sphacelarioides Derb. \& Sol ..... 75

Gloeogenae Cohn .......................... 20

Gloeocapsa (K.g) Naeg ................ 23, 27

crepidinum Thuret.................. 27

Itzigrohnii Bornet.................. . 27

steyophila Itzigs .................. 27

Glaeotrichia............................. 38

Gloiosiphonia Carm ................ 120, 141, 142

capillaris Carm ................... 141

Gongroceras strictum K.g............... 136

Gongylospermeat........................ 106

Goniotrichum K.g.................110, 111, 11:3

corulescens Zan ...................... 113

elegans Zan....................... 113

Gracilaria Grev........................161, 16:3

compressa Grev .................... 164

confervoides Grev .................. 164

lichenoides $\mathrm{Ag}$.................... 184

multipartita $\mathrm{Ag}_{\mathrm{g}} \ldots \ldots \ldots \ldots \ldots \ldots \ldots .6, \mathbf{6}, \mathbf{1 6 4}$

จ. angustissima Harv......... 164

Griffithain Ag ..........................118, 130

barbata Ag......................... $\quad 130$

Bormetiana Farlow................ 131

corallins $\mathrm{Ag}$...................... 131, 132

equisetifolius $\mathrm{Ag}$................... 132

globifera Ag ....................... 131

ylublalifera K. K................... 131

setacea $\mathrm{Ag}$....................... 131

tenuis Ag ........................... 130

Grinnellia Hnrv.................... 161, 102

A mericana Harv ..................... 6, 161

Cismangongrus Mart.................144, 145 
Gymnogonarus Griffithsice Ag. ......... Page. Norvegicus Ag ..................146, 149 plicatus K.g... 147 Torreyi Ag

146

Gymnophloea $\mathrm{Ag}$

\section{II.}

Homatococcus binalis Hassal............. Halidrys Lyngb........................ Haliseris polypodioides $\mathrm{Ag}$...............

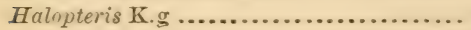

Halosaccion K.g...............81, 89, 14 mierosporum Rupr................ ramentaceum $\mathrm{Ag}$. จ. gladiatum Eaton

Halurus K.g ........................ equisetifolius $\mathrm{K} . \mathrm{g}$.

Halymenia Ag ......................... ligulata Ag ......................

Helminthocladia Ag.

Helminthocladiece

Helminthora Ag ........................

Herpothamnion Naeg ................. Turneri Naeg...

Hildenbrandtia Nardo................... rivularis J. Ag.................... rosea K.g. rubra Harv

Himanthalia lorea Ljngb ................

Hormactis Thuret. Balani Thuret.

\section{Farlowii Bornet.} Quoyi (Ag.) Bornet

Hormoceras Capri-Cornu Peinsoh......

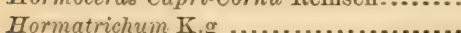
boreale Eaton

Carmichaelii Harv

collabens K.g. speciosum Eaton Younganum K.g

Hydroclathrus Bory .

Нурпељ

H musciformis L. $\mathbf{x}$.

' purpurasccns Harv

Hypoglossum Grayanum Reinsch ......... Leprieurii K.g.

\section{I.}

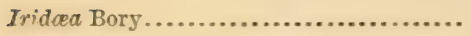
Irish-moss.

Isactis Thuret plana Thuret

J.

Jania L.X

\section{I.}

Laminariacea $12,61,92$

Laminarieæ

17,90

Laminaria L. $\mathbf{x}$ $15, \mathbf{9 2}, 95,99$ agarum De la Pyl ................. " apoda Harv ......................... Boryi De la Pyl .................... " caspitosa Ag...
Laminaria caperata De la Pyl.

Page.

Claustoni Le Jolis .................. 95

"debilis Crouan..................... 62

"dermatodea De la Pyl............ 92,95

digitata L.x..................... 92,94

esculenta De la Pyl.................. 98

"v. platyphylla De la Pyl........ 98

" v. remotifolia De la Pyl........ 98

" v. taeriata De la Pyl ........... 98

fracia Ag ..........................15, 62, 92

fascia Harv .................... 62

flexicaulis Le Jolis.................. 94, 95

Ixtifolia Ag ........................ 94

linearis De la Pyl ................... $\quad 97$

longicruris De la Pyl .........5, 10, 92, 93, 94

lorea Ag .......................... 92,95

musafolia De la Pyl ................. $\quad 97$

phyllitis Harv ...................... 93

platymeris De la Pyl................ 94,95

Pylaii Bory ....................... 98

saecharina L.x ...................92, 93, 91

"v. caperata (De la Pyl.) ........ 94

" ". phyllitis Le Jolis............. 93

вc8sitis Ag ....................... 92

snlidungulx Ag .................. 92,95

stenoloba De la Pyl................ 94

trilaminata Olney.................. 92

Laurencia L.x ....................... 165, 166

Baileyana Mont ................... 166

dasyphila Ag .................... 166, 167

tenuissima Grev .................... 166, 167

Laver ............................... 9

Leathesieæ.......................... 16, 79

Leathesia S. F. Gray..................15, 81, 82

difformis Aresch................. $\quad 82$

tuberiformis S. F. Gray............ 4, 57,82

Leibleinia K.g ...................... $\quad 36$

amethystea K.g.................. 36

"chalybea K.g...................... $\quad 36$

Lemanea ........................... 108

Leptothrix rigidula $\mathrm{K} . \mathrm{g}$................ $\quad 32$

Iiagera L.x ........................ 116

Linckia atra Ljngb ................... $\quad 38$

Lithoderma fatiscen 8 Aresch ............ $\quad 88$

Lithophyllum Rosanoff ................... 179, 180

Len.rmandi Rosanoff............. 181

Lithothamnion Phil .................. 182

fasciculatum Aresch ............... 5

polymorphum Aresch .............179, 182

Litosiphon pusillus Harv ................. 64

Lomentarieæ........................ $\quad 149$

Lomentaria Thuret.............149, 154, 155, 156

"Baileyana (Harv.) ................. 4,6 rosea Thuret ...................124, 149, 155

uncinata Menegh ................4, 154, 155

" " v. filiformis Harv ............. 155

Lyngbya Ag ......................11, 34, 183 æestuarii Liebm .................. 34, 36

" aruginosa Ag..................... 34

"Carmichnelii Harv................. 45

crispa Ag....................... 34

Cutlerice Harv ................... 45

ferruginea Ag ..................... 34

flacca Harr ....................... 45

" fulva Harv........................ $\quad 35$ 
Page.

L! n:giva luteo-fases Ag.

Kürringiana Thuret

"6 majuecula Harv.

4. nigrescens Harv

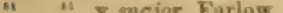

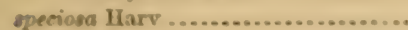

tenerrima Thuret

I.

Meracystis pyrifera $\mathbf{\Delta g}$

Melanophycere Reinsch

Mriannepermece . .

Melobesin A resch.

"farinosa A resch

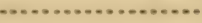

farinosa Harv .......................

" farinowa K. g .......................

"f farinosa L.x ....................... 180, 181

". fasciculata Harv .................... 182

si Le Jolisii Rosanoff ................ 1S0, 181

ss Lemormandi Aresch................. 151

at macrocarpa Rosanoff............... 181

"s membranacea A resch ............... 180

ss polymorpha Harv ................... 182

" pustulata L.x.................... 1S1

os vermuene Harv ..................... 180

Menuaid's hair....................... 12,34

Mesogloia Ag.....................83, 84, 106

" divaricata K.g ....................

“ multifida Ag.

84

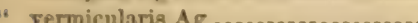

ss virescens Carm ......................

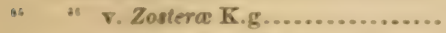

๑. Zostericola Harv

Zosterce Aresch

Microcoleus Desm

". anguiformis Harv.

"s chthouoplastes Thuret.

as terreatris Desm.

6. rersicolor Thunet.

Mierocystis K.g

") elabens K.g ........................

Microhaloa rosea $\mathbf{K} . \mathrm{g}$.

Millepora Anct.

- fasciculata L.k.

informis L.k.

Monostromn (Thuret) Witts

" Blvttii Wittr ........................

". crepidinum Farlow ..................

4t Grevillei Wittr .....................

" orbiculatum Thuret.................

" pulchram Farlow.

"Wittrockii Bornet.

Mfyriactis $\mathrm{K}$.

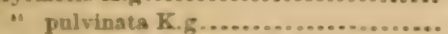

“ $\quad$.. r. mumur Farlow .............

Myrincladia Zostera Ag ..................

Myrionemen ...........................

Myrionema Grev .............15, 70, 78, 81, 87, 88

- clavatum Carm

"Leclancherii Harv..................

"s maeulvorme K.g...................

" punctivorme Harv.

1) strangulano Grev

" Vulgare Thuret

Mrriotrichin Harv.
Myriotrichis clarpformis Harv ...........

Page.

67

64

filiformis Harv......................

Harveyana Xiveg..................

68

N.

67,08

Nemaliem $.25,116,142,178$

Nemalion Duby ...............20, 106, 107, 108, 117 multifilum $\mathbf{A g}$....

117 purpureum Chauv

Nemastoma $\mathrm{Ag}$........................120, 14:2

Bairdii Farlow ................... 2, 142

marginivera Ag.................. 142

Nematogenas Cohn...................... 29

Nerencystis Post \& Rupr ................. $\quad 15$

Nitophyllum (irev................... 7 ocellatum Grev..................... 7

Nodularia Mertens ..................... 31

"Harveyana Thuret .................. $\mathbf{3 1}$

Nostoo Tauch.......................... 12

Nostochinere........................ 11, 25

Nullipora A uct........................ 179

\section{0.}

Odonthalia Lyngb...................... 168 dentata Lyngb................. 6, 168

furcata Reinsch................. 168

Gdogonium Lk ....................... 60

Omphalaria Dur. \& Mont ............... 27

Oncotylus Norvegicue K.g ................ 146

Oosporesв ........................14, 17, 25, 98

Oscillaria K.g....................11, 12, 32

" limosa v. chalybea K.g............ $\mathbf{3 3}$

" litturalis Harv .................. 33

subtorulosa (Bréb.) ............... 33

gubuliformis Harv ................ 33

Oscillatoriacea .......................... 12

Oscillatoria, see Oscillaria. chthonoplastce Lyngb .............. 33 crustacea Schonsb................. 36

Ozothallia D.c.ne \& Thuret.............. 89 nodosa D.c.ne \& Thuret........... 100

Padina pavonia Gaillon ................. 7

Palmellacea.......................... 26

Pandorina ........................... 13

Peletia D.c.ne \& Thuret................ 99

Petrocelis Ag .......................115, 110 cruentr $\mathrm{Ag}$...................... 5,115

Petrospongium Naeg ..................... 10

Peyssonnelia D.c.ne .................... 114 anstrabis . ond .................... 114

" Dubyi Cronan .................... 114 imbricata K.g..................... 115 squamaria D.c.no ................. 114

Phasporem ...............13, 14, 25, 61, 106, 183 Pheenzosporea, see Phacoporex.

Phlebothnmnion byssoides K.g.......... 127

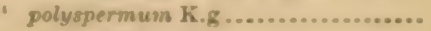

"4 roseum K.g ....................... 125

"s scirospermum K.g ............... 129

Phlaeorpora Aresch................... 5, 08

"tortilis A resch .................... 5

Phloiocaulon Geyler.................. 77 
Phormidium K.g.................... Page.

Kützingianum Le Jolis.............. 36

subtorulosum Bréb ................

Phycochromacea.

Phycophila K.g.. gardhii

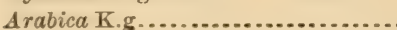

fucorum K.g......................

Phyllitis Le Jolis . cospitosa Le Jolis.................

fascia K.g...................... 5,62 v. cæespitosa Harv

62

Phyllophora Grev

145, 146

Brodiæi Ag

4,145

Clevelandii Farlow

145

membranifolia Ag

4,145

Phycoseris australis K.g

crispata K.g

gigantea $\mathbf{K} . \mathrm{g}$

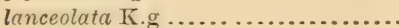

myriotremn K.g...................

Physactis atropurpurea K.g............. obducens K.g ...................... plicata K........

Pleonosporium $\mathrm{Naeg}$

Pleurococcus crepidinum Rab rosen-persicinus Rab ................

Plocamium Lyngb

Californicum K.g..................

coccineum Lyngb.

Pocilothamnion byssoideum Naeg ........ corymbosum Naeg.................. seirospermum Naeg

42

43

42,43

43

42

39

39

39

124

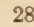

29

150

151

151

127

128

129

Polyides Ag

rotundus Grev

$.21,160$

Polycystis K.g.

$4,118,160$

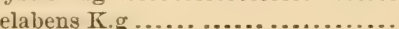

pallida K.g.

28

28

28

Polysiphonia Grev ..............168, 169, 176, 177 affinis Harv ....................... 175

Americana Reinsch ................ 172

arctica $\mathrm{Ag}$........................

arietina Bailey

5

atro-rubescens Grev ................

Brodicei Grev

174

173

$17: 2$

elongata Grer.

4, 175

fibrillosa Grev

172,173

formosa Harv

170

Harveyi Bailey

$6,170,171,172$

nigrescens Grev

4, 174

v. affinis Ag.

174

v. Durkeei Harv

174

v. fucoides $\mathbf{A} g$

174

Olneyi Harv.

172

parasitica Grev.

1 ร 4

v. dendroidea ..................

174

spinulosa Grev......................

subcontorta Peck.

172

170

subtilissima Mont

170,171

v. Westpointensis Harv

171

urceolata Grev

4,170

170

v. formosa $\mathrm{Ag}$

170
Pnlysiphonia violacea Grev v. flexicaulis Harv

Page.

Porphrreæ 25, 106, 110

Porphyra Ag .........................110, 111

laciniata Ag....................111, 112

leucosticta Thuret................... 112

linearis Grev...................... $\quad 111$

vulgaris Harv.................... 9,111

Potamogeton L ....................... $\quad 10$

Prionitis Ag ........................... 141

Protococcus crepidinum Thuret.......... - $\quad 27$ rosea K.g ........................ $\quad 29$ turgidus K.g..................... 27

Protophytes......................... 11, 26

Pseudoblaste Reinsch...................109, 110 irregularis Reinsch .............. 110

Pterocladia Ag........................ 157, 158

Pterothamnion Americanum Naeg ....... 123 floccosum Naeg .................... 122

Pylaiscei Naeg ...................... 123

Ptilota Ag...........................133, 174 elegans Bonnem ................. 4, 133 plumosa Ag..................... 134

v. tenuissima Ag............ 133 serrata K.g..................6, 8, 133

Punctarieæ .......................... 16,63

Punctaria Grev ....................... 63, 90 latifolia Grev ..................... 64 v. Zosteræ Lo Jolis............. 64 plantaginea Grev................... 64 tenuissima Grev .................. 64

Pylaiella Bory.......................... 68, littoralis Kjellm ................. 73

\section{R.}

Ralfsieæ.......................... 17, 86

Ralfsia Berk......................15, 79, 87, 88 clavata Crouan ..................79, 87, 88 densta J. Ag .................... 87 deusta Berk....................... 87 verrucosa Aresch................. 5,87

Rhabdonia Ag...................147, 149, 158 Baileyi Harv....................... 159

tenera Ag.....................4, 6, 7, 159

Rhizoclonium K.g ..................... 48 Kochianum K.g ................ $\quad 49$

Linum Thuret................... $\quad 47$ riparium Roth .................... $\quad 49$ salinum K.g.................... 49 tortuosum K.g.................... 49

Rhodochorton Naeg...................120, 121 Rothii Naeg....................... 121, 133

Rhodomeleæ ......................25, 164, 177

Rhodomela J. Ag....................165, 168, 176 gracilis Harv..................... 169 Rochei Harv ........................ 169 subfusca $\mathrm{Ag}$....................... 169 v. gracilior Ag.............. 169

Rhodonema elegans Martens............. $\quad 177$

Rhodophylleæ......................... 149

Rhodophyllis K.g .................149, 152,153 bifida. K.g .................... 152 dichotoma Lepechin................ 153 veprecula Ag ..............5, 149, 152,153 v. cirrhata Harv ............ 152 
Page.

Rhederpermetr $10,19,106$

Rhend unentese

Rlunlymenta $1 \mathrm{~g}$

cristated lifes.

palmats Gires

1. Sanniensid

$25,149,158,161,164$

$145,150,151,15 \%$

153

$.4,9,142,150$

150

Rivularia lioth.

11,37

atra Rinth.

35

hospita Thuret

35

nitida Farlow

89,40

parasitica Chaurin

plicata Carm.

tuberiformis Kngl. Bot

Ruppia maritima I.

Rytiphlea $\mathbf{A g}$

Saccharomyeetes. .

Saccorhiza De la Pyl .

bulbora De la Prl

"dermatodea De la Pyl.

Sergasanm $\mathrm{Ag}_{\mathrm{g}}$.

99,103

bacciferum $\mathrm{Ag}$

103

" Montagnei Bailey

103

" valgare $\mathbf{\Lambda g}$.

4, 6, 103

" " . Montagnei Farlow

103

117

Scinaia Birona

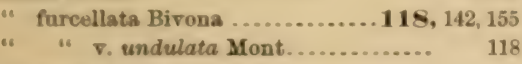

Schizophyte Cubn

Schizosiphon K.g

\section{fasciculatus K.g}

lariopus K.g .

pararitious Le Jolis

Schisymenia Ag.

Scytosiphon Thuret.

16 flum $\mathrm{Ag}$.......

91
$9 . \ldots \ldots \ldots .15,63,66,88,91$

4 faniculaceus Ag ................ 86

". hippuruides Lyngb

"comentarins Ag........... 63, 89

Seiroepora Harv ...................120, 121, 129

Griffithsiana Harr

Siphonea

129

Solieriem ..............25, 149, 158

Soliera chordalis Harv .................. 148, 169

Epermatochnus rhizodes K.g........... 90

Spermosira K. . ................... 31

4 Harveyana Thwaites .............. 31

Spermothamnier. .................. 25, 118

Spermothamnion Aresch ........ 1 18, 120, 125, 131

is Rabellatum Born .......... ........ 119

" hermaphroditum (Naeg.) ........... 119

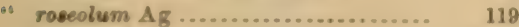

* Tumeri Aresch ................... 119

o $"$ " v. variabile Harv ............ 119

Sphacelariem

16,75

Sphacelaria Lyogb

15.75

cirrhose $\mathbf{A g}$

dadalea Reinsch

fusca Ag

oliveces $\mathbf{A g}$. . . . . . . . . . . . . . . . .

"plumasa Lyngb

76

77

76

76

77

76, 133

stribuloides Menegh.
Aphrenosiplion Reinsch

Page.

olivaceus Reinnch.............. 6

rospus keiusch ... . . ..........

mmuragdines Reinsch ............ 61

Sphorria Hall ....................... 10

Aipharocnccoidea . ................25, 149, 16!

Spharococeus coronopifolius Ag.......... 154

cristatus Ag.................... 150

Norvegicus $\mathrm{Ag}$................... 140

plicatus Ag....................... 147

Torreyi $\mathrm{Ag}_{\mathrm{g}} \ldots \ldots \ldots \ldots \ldots \ldots \ldots \ldots \ldots . \ldots \ldots$

Sphremzygn $\Delta g$................... 30

Carmichaelii Harv ............... 30

Spirulina Turpin .................... 12,31

Thuretii Cruuan ................. 31

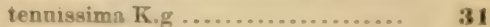

Spongiocarpero ....................... 25, 160

Spongites K.g ....................... 179

Spongomorpha K.g................... 50,52

Spongonema tomentosum K.g............ 70

Sporochnaceas ...................... 61, 183

Sporochners .......................... 11,89

Sporochnus thizodes $\Delta \mathrm{g}$................ 90

Spyridiew ............................ 25, 139

Bpyridia Harv .................... 140

flamentosa Harv............... 8, 20, 140

. $\quad$ ". refracta Harv............ 140

Striaria Grev .........................

attenuata Grev .................. 90

Squamariea.................8, 21, 25, 113, 178

Stietosiphonia H. \& H................... 176

Stigonema $\mathrm{Ag}$....................... 67

mamillosum Ag.................. 40

Stilophora Ag ........................ 89, 183

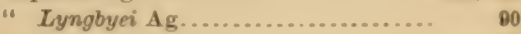

. papillosa Ag ...................... 90

rhizodes $\mathrm{Ag}$..................... 90

Streblonema Derb. \& Sol..........24, 57, 68, 69

fasciculatum Thuret .............. 69

spharicum Thuret ... ............ 69

Stypocaulon K.g..................... $\quad 75$

Symploea K.g ....................... 183

" fasciculata K.g .................. 183

Synalissa Fr .......................... 27

T.

Toenioma $\mathrm{Ag}$..................... 177

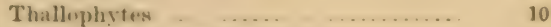

Thamnidium Rothii Thuret........... 121

Tilopteris K.g...................... 7

Tremella difformis L.................. 82

Trentepohlia Pringsh .................. 108

". Daviesii Harv ..................... 108, 109

". virgatula (Harv.)....... . . ....... 108, 109

" " $"$. secundata (Lyngb.) .... 109

Dlothrix (K.g.) Thoret................ 44

" collabens (Ag.) Thuret ........... 45

"1 flacea (Dillw.) Thuret.............. 45

isogons Thuret ................. $\mathbf{4 5}$

“ vonata K. F.................... 45

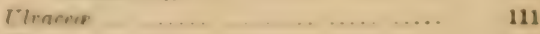

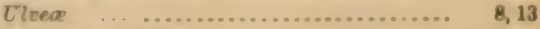

Uiva (L.) Lo Jolis ......................... 41, 42 


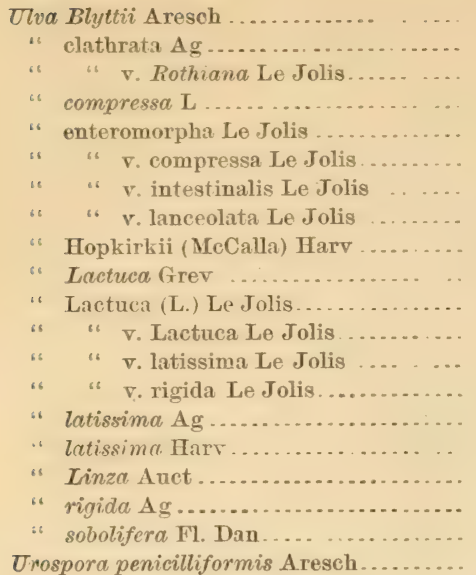

\section{v.}

Vaucherieæ
Pane.

41

44

44

43,44

43

43

43, 44

43

44

41

$4 \cdot 2$

43

43

42

42

43

41,43

42

143

45

Vaucheria D.C

Page.

clavata Lyngb .................. 105

"geminata Walz ................. 105

" litorea Nordstedt. ............... 105, 106

piloboloides Farlow ................ 105

"Thuretii Wor.................. 104

"velutina Ag.................. 105

Verrucaria.

" maura T. Fr.................. 10

" mucosa T. Fr................... 10

" prlodytes $\mathrm{Nyl} \ldots \ldots \ldots \ldots \ldots \ldots \ldots . . . . . . .28$

$\mathbf{W}$.

Wrangeliea ....................... 120

Wrangelia Ag ....................... 119, 123

" penicillata Ag.................... 119

"Pylaisoi Ag .................... 123

Zannichellia palustris L ................ 10

Zonotrichia hemisphorica $\mathbf{A g} \ldots \ldots . . . \quad 38$

Zostera marina $\mathrm{L}$.................. 9

Zoosporeæ...................12, 17, 25, 10 


\section{ERRATA.}

Page $\mathrm{I}$, top line. for diatomes read diatoms.

Page 5. I Sth line from top and page +1 , 7 th line from bottom. for Blytii read Blyttii.

P'age fo. zand line from top. for Clorospermeac read Chlorospermeae.

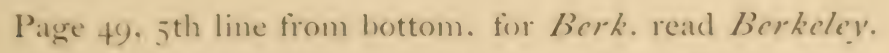

Page S7. after R. acrucosa Aresch. insert Plate 5 , fig. 5 .

Page i 18 , zoth line from top. for undulad read undulata.

Page I40, Ist line. for genus read suborder.

Page 183 , 2oth line from top. for Daby read Duby. 



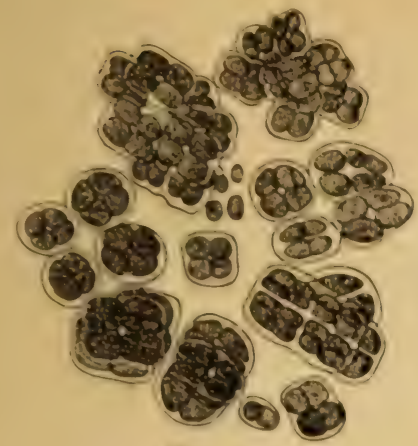

Fig. 1.

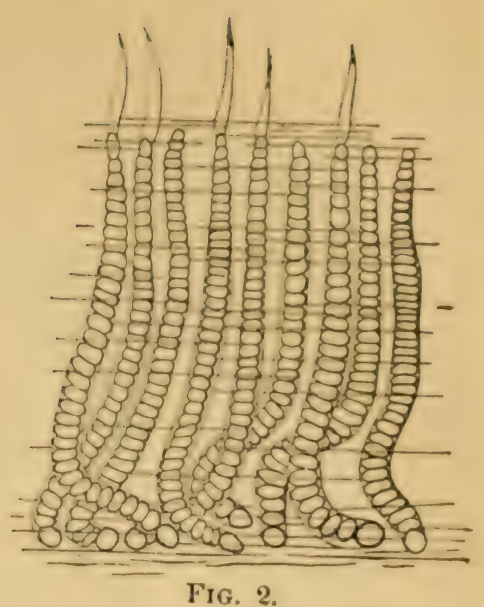

FIG. 3.

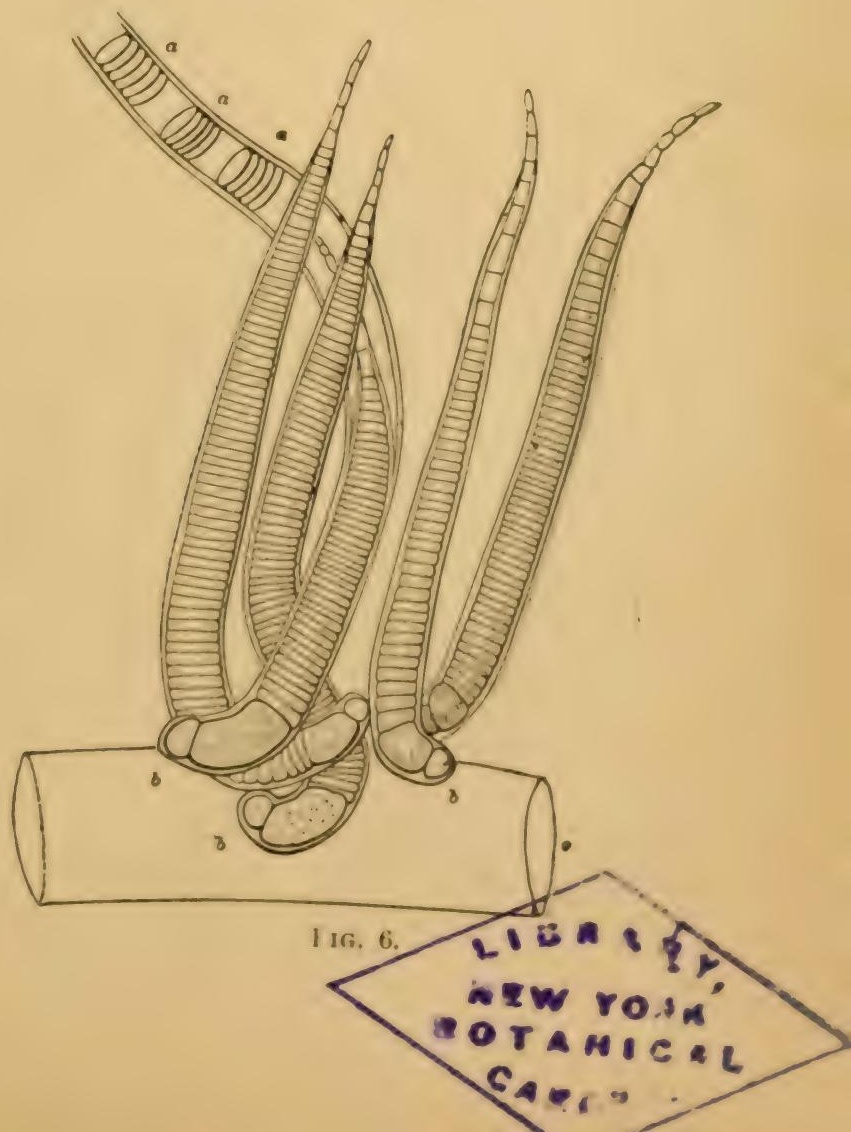





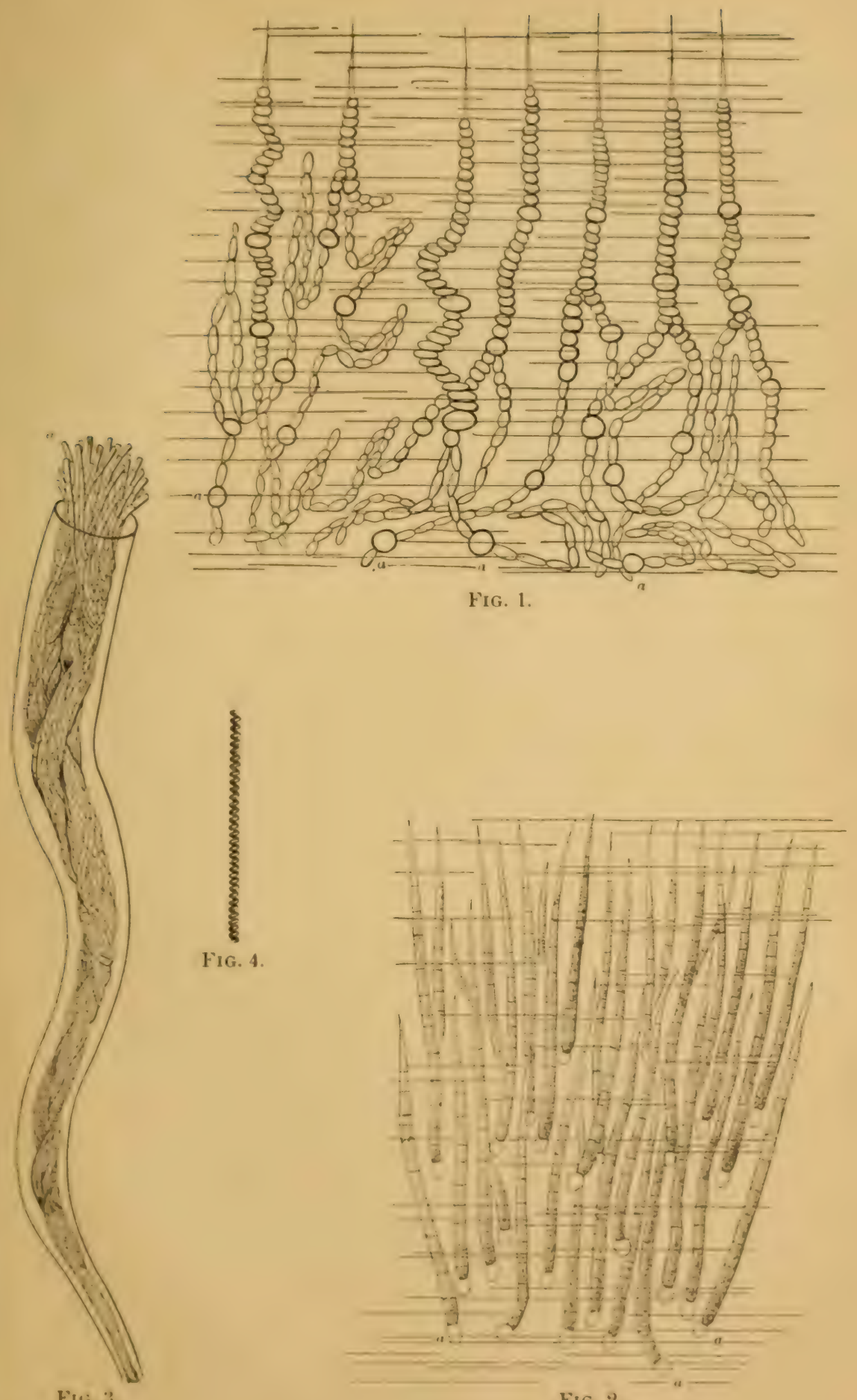

Fui. 3.

Fig. 2. 


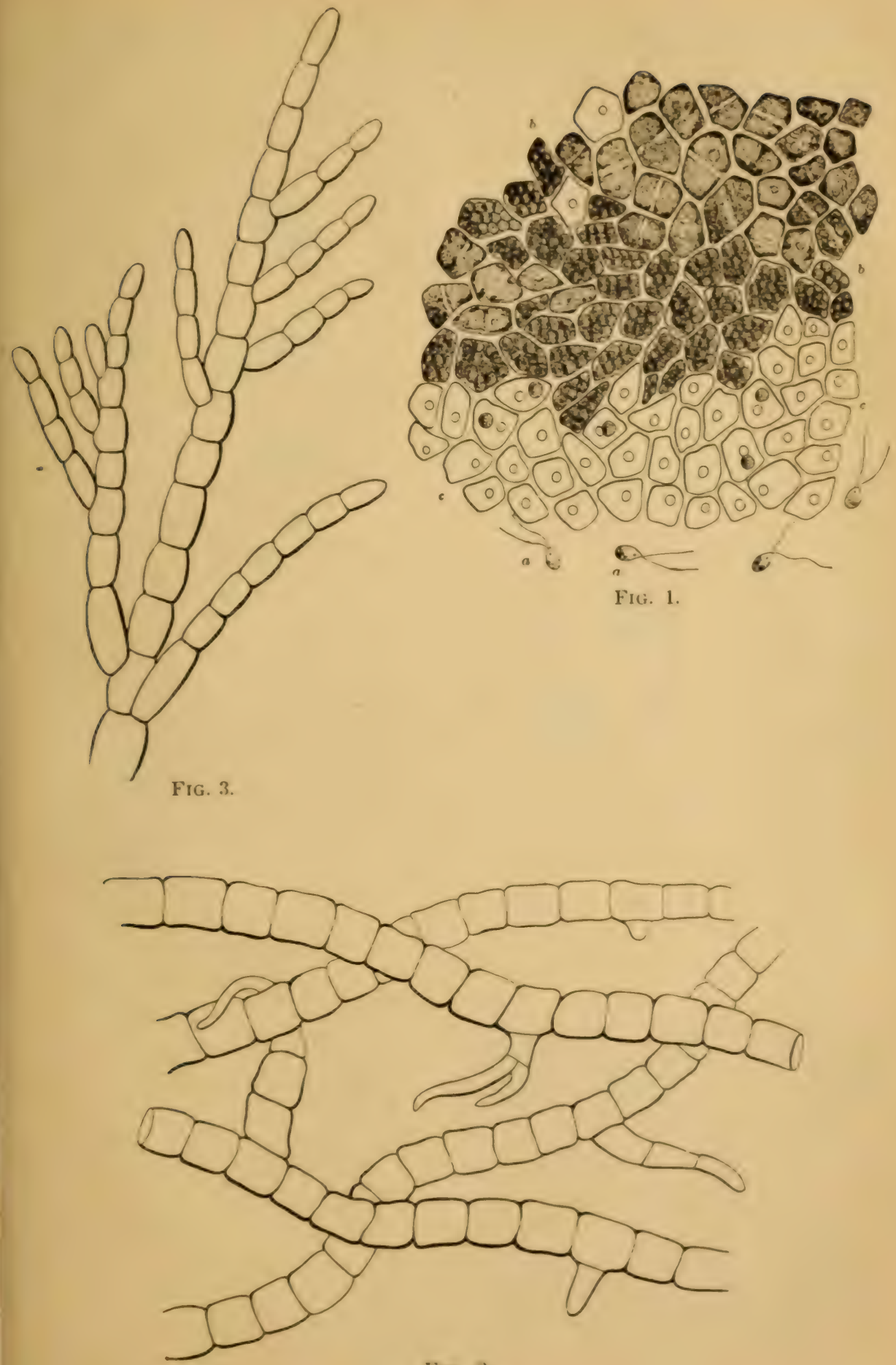

Fig. 2. 



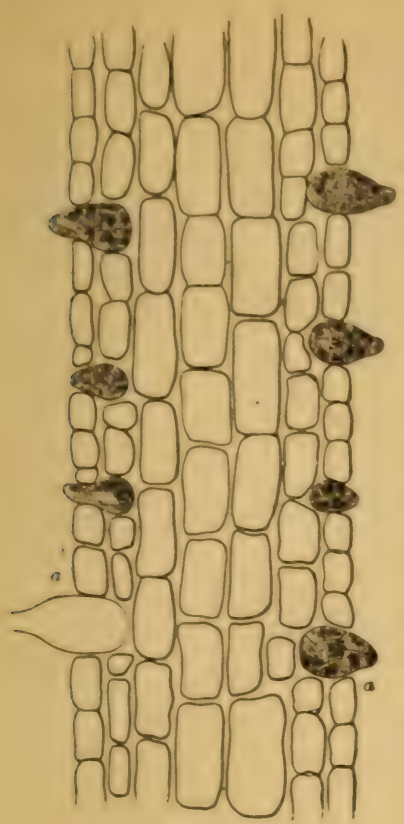

Fig. 5.

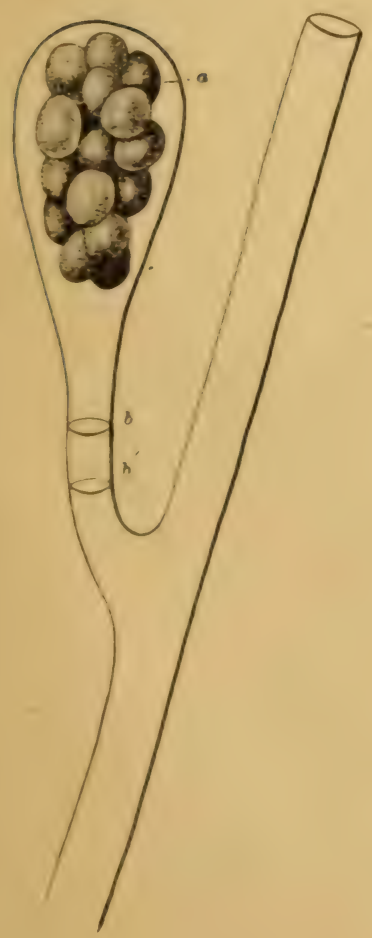

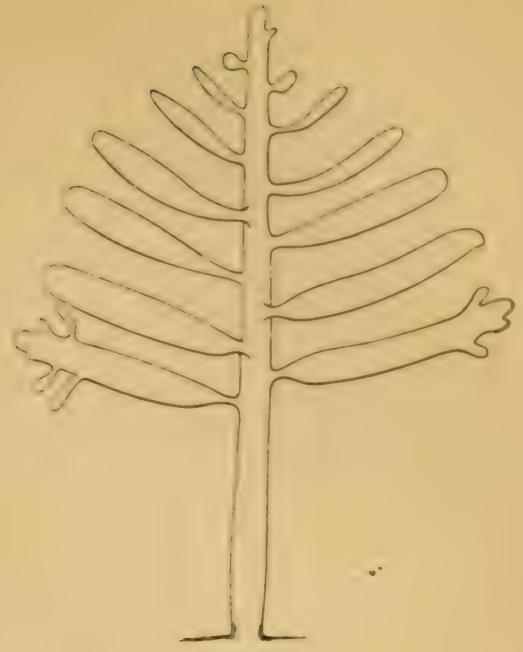

Fili, 1.

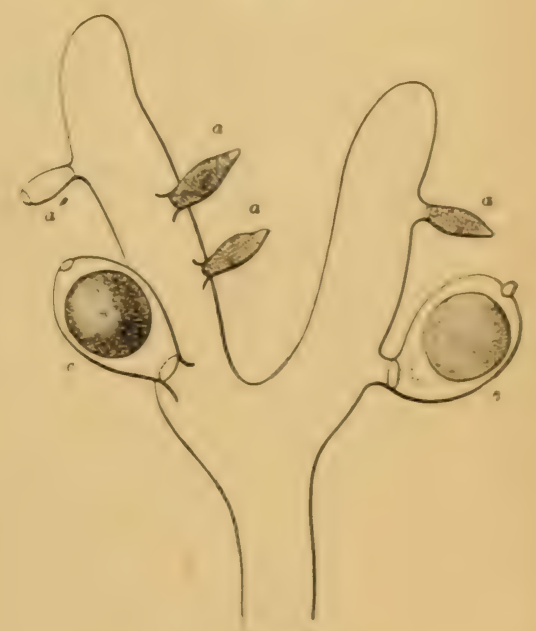

Fia. 2.

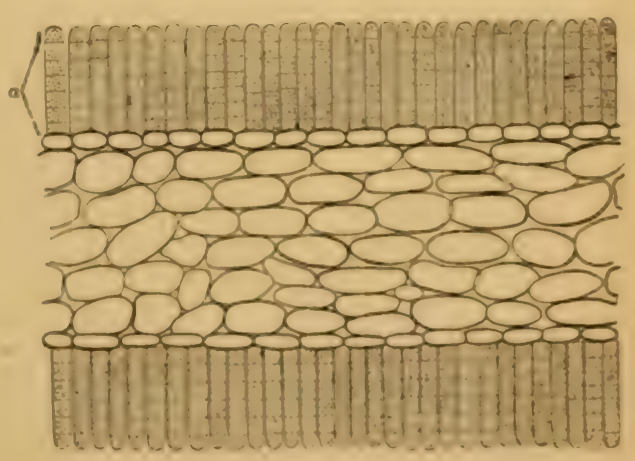

FIG. 3. 

Report U. S. F. C. 1879-Farlow. Marine Alga.

Plate V.
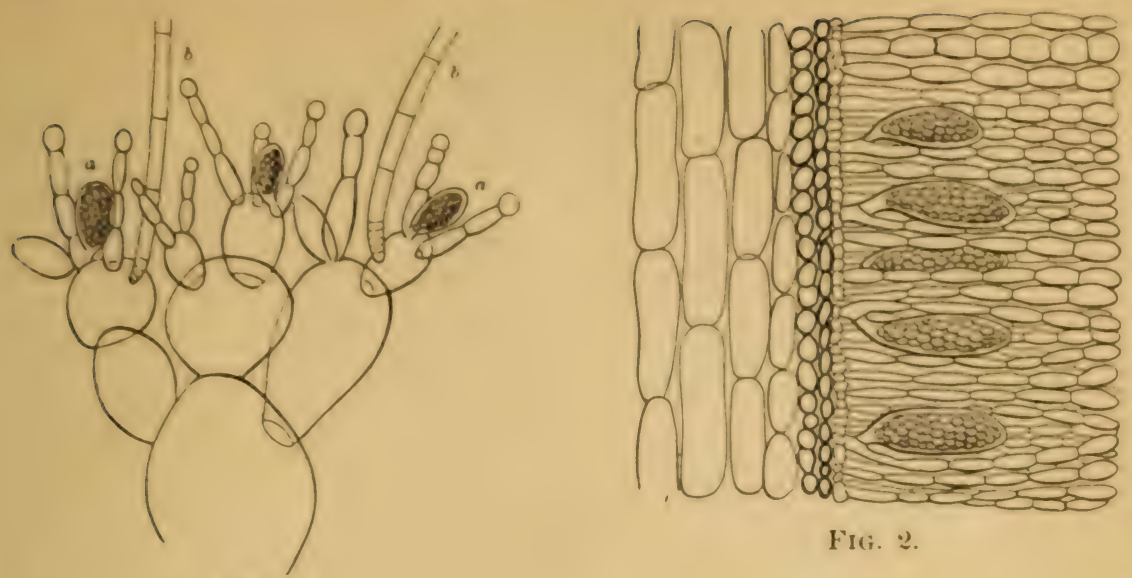

FI(i. :).
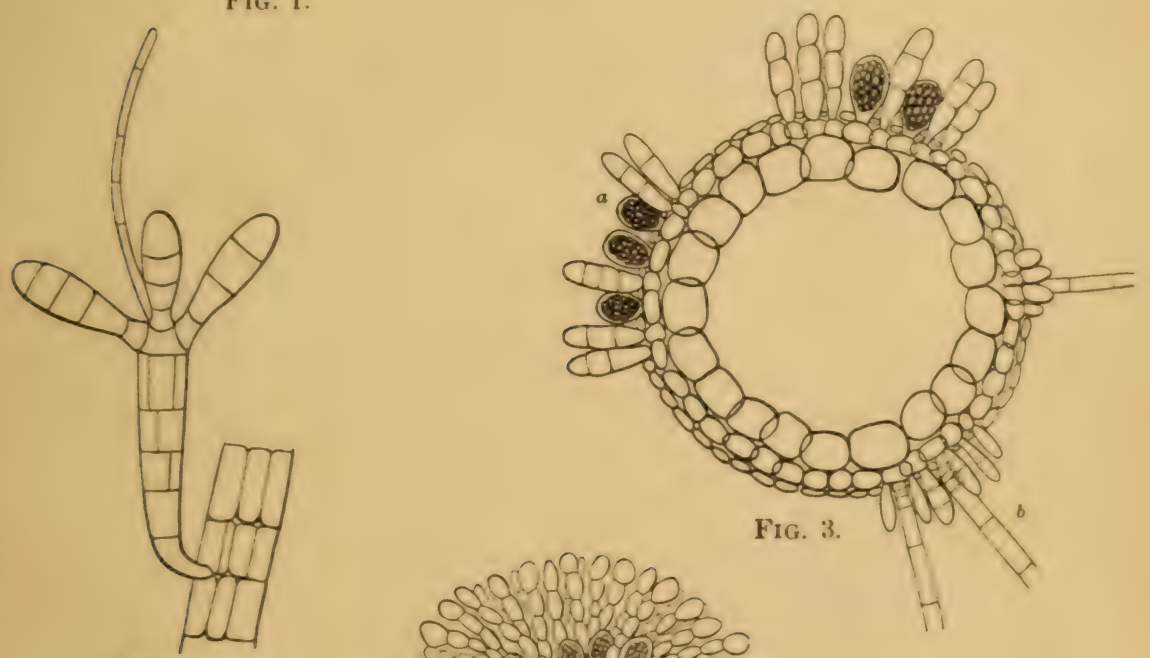

Fig. 6 .

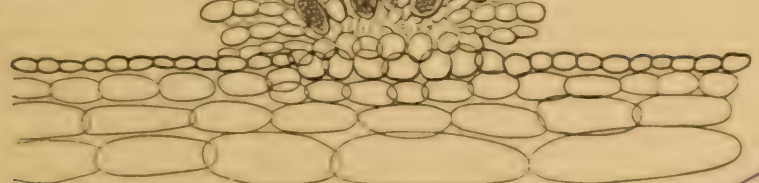

F'IG. 4.

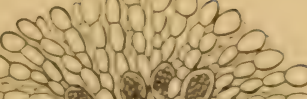

Fig. 3.

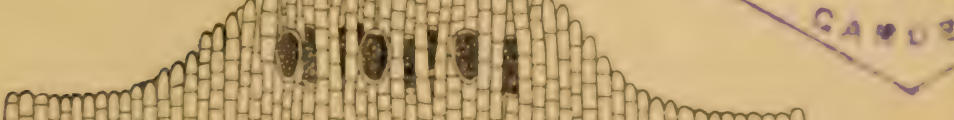

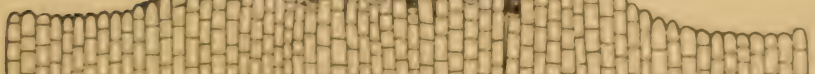

HHI

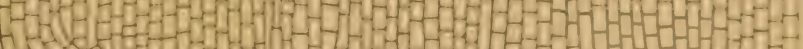

as

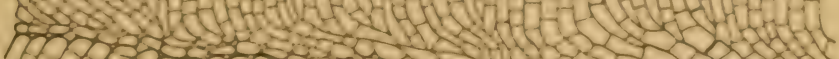

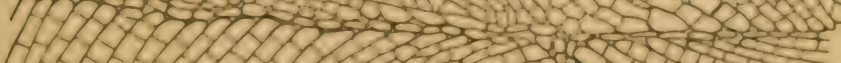

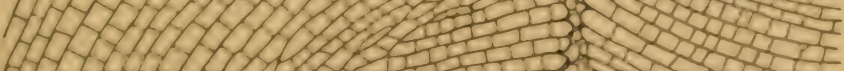

Fig. : 



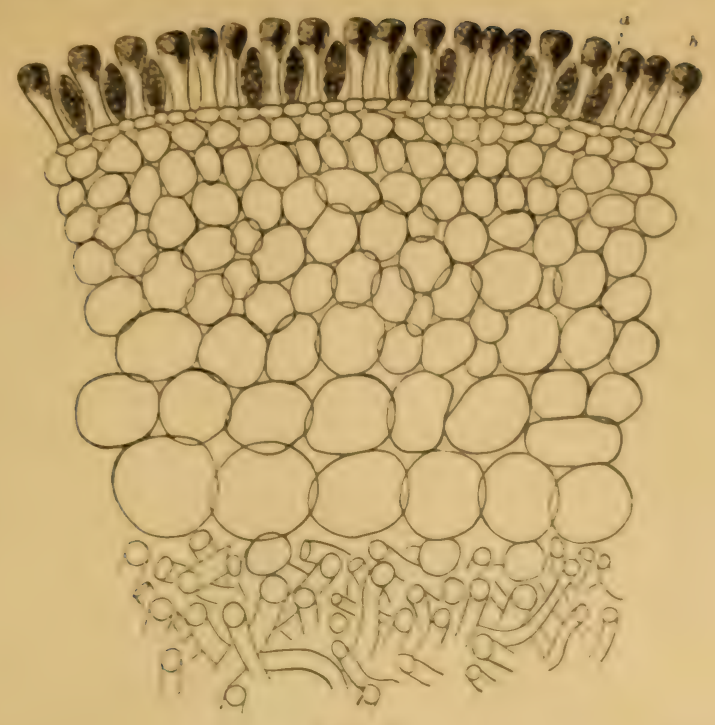

FIg. 1.

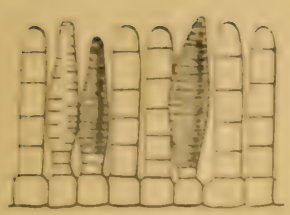

Fig. :.

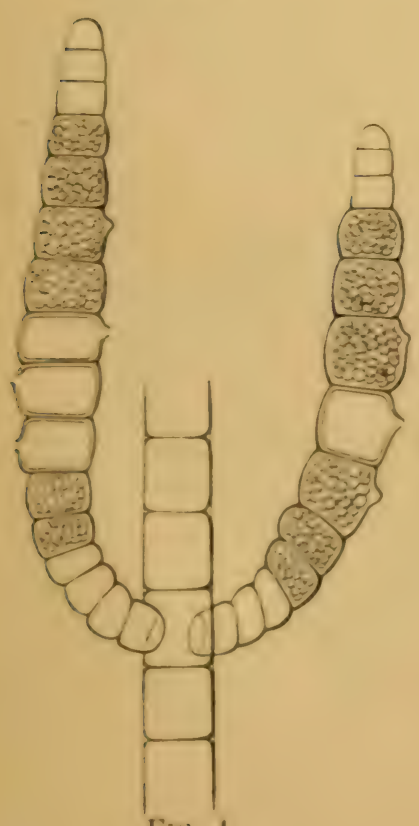

Fir: 1

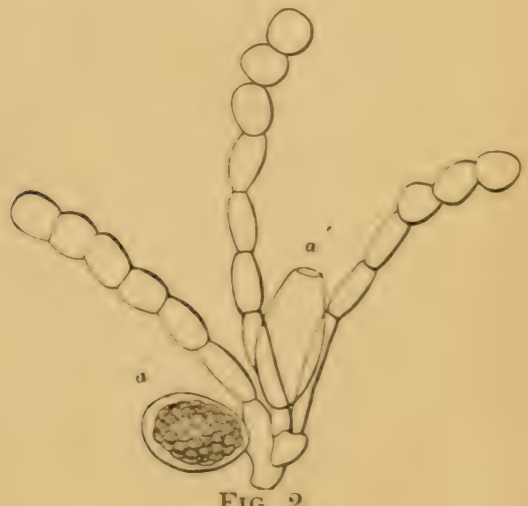

FIG. 2.

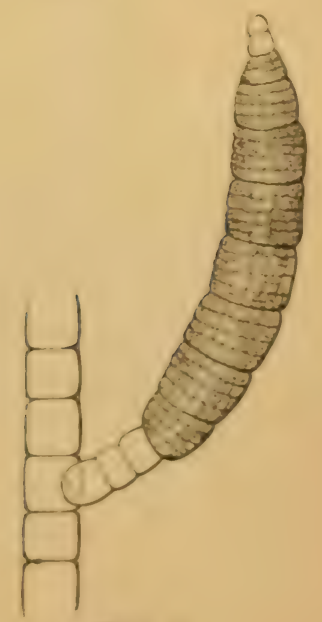

FIG. 3. 


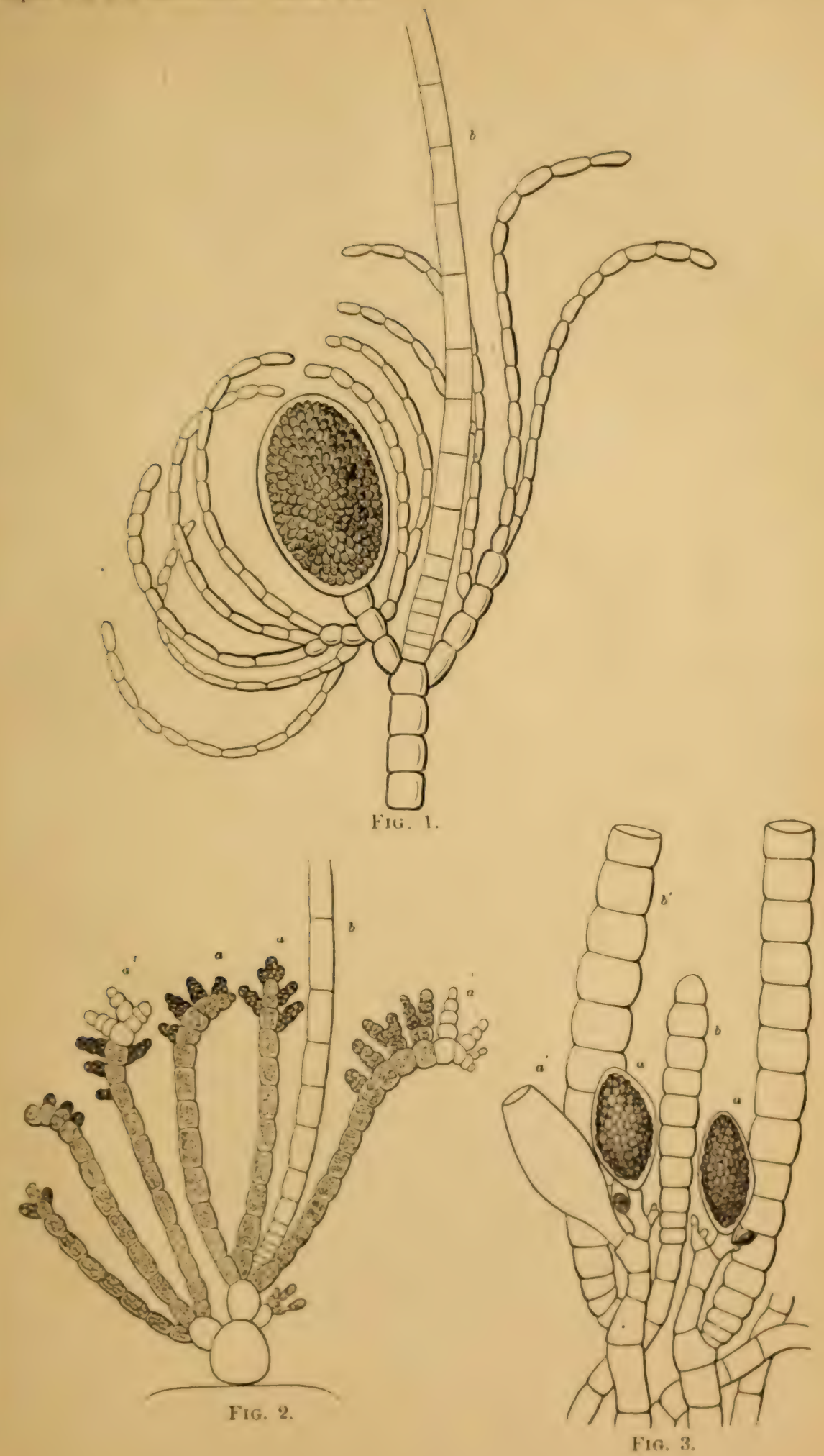


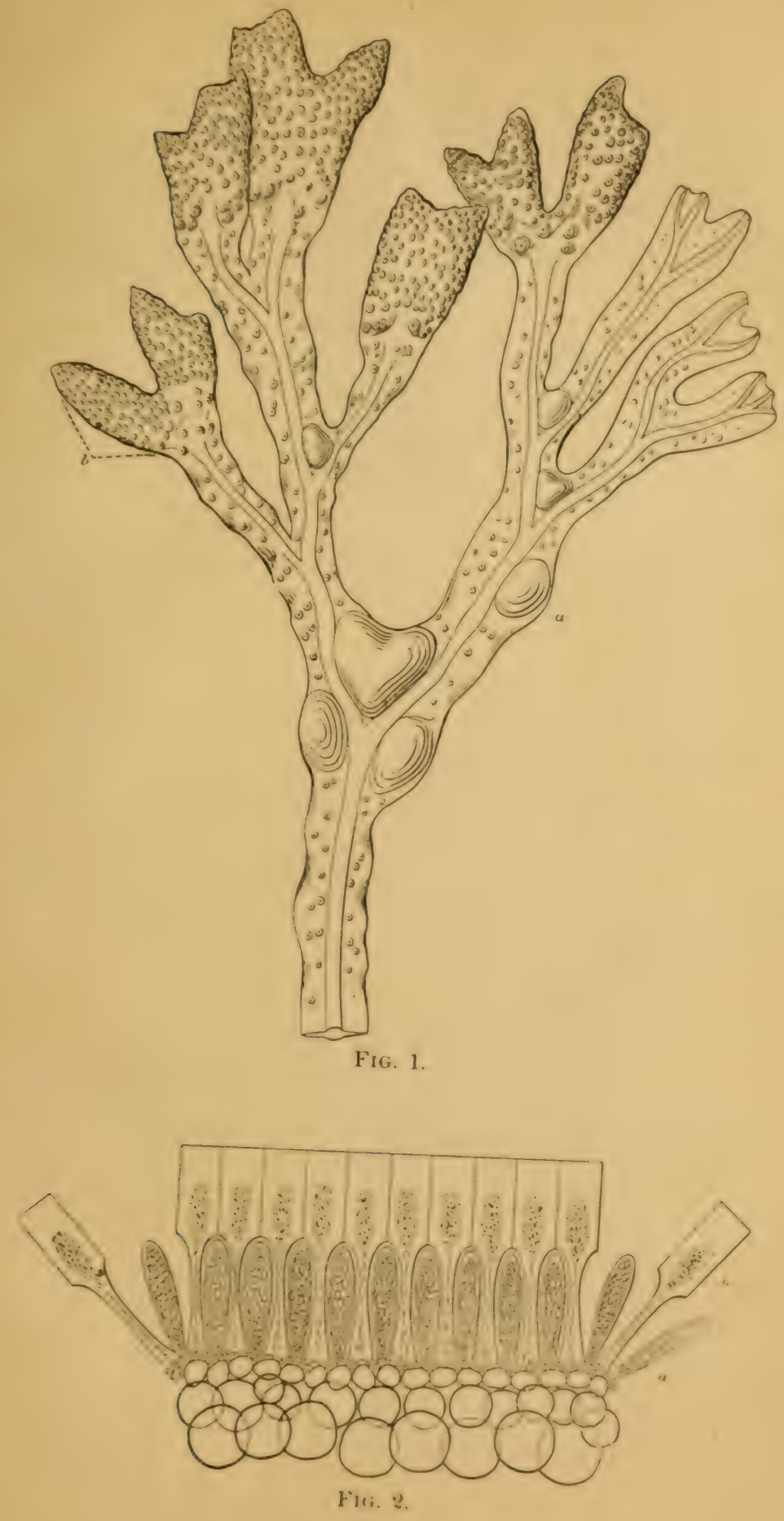


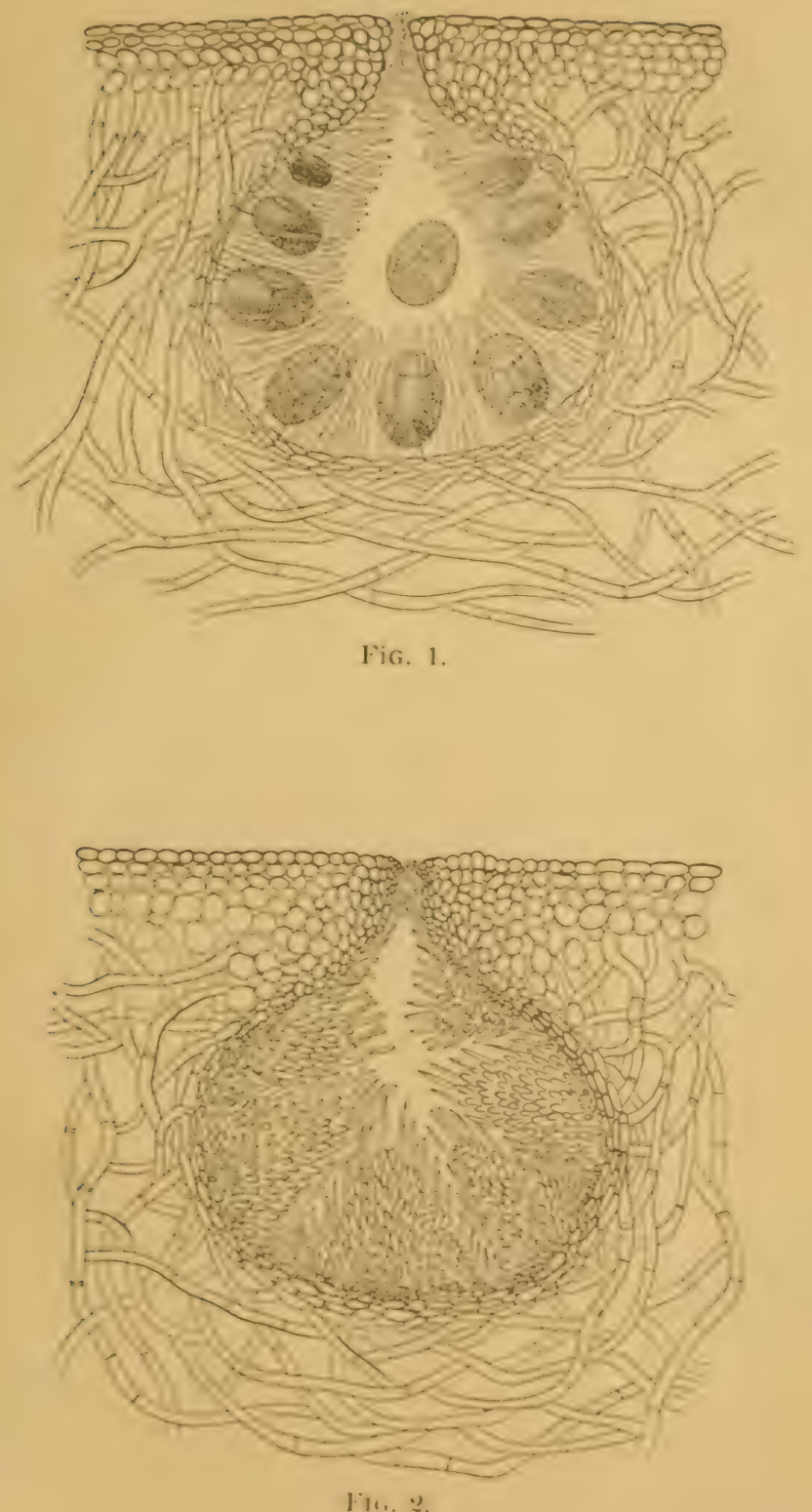

Fin. 2 . 



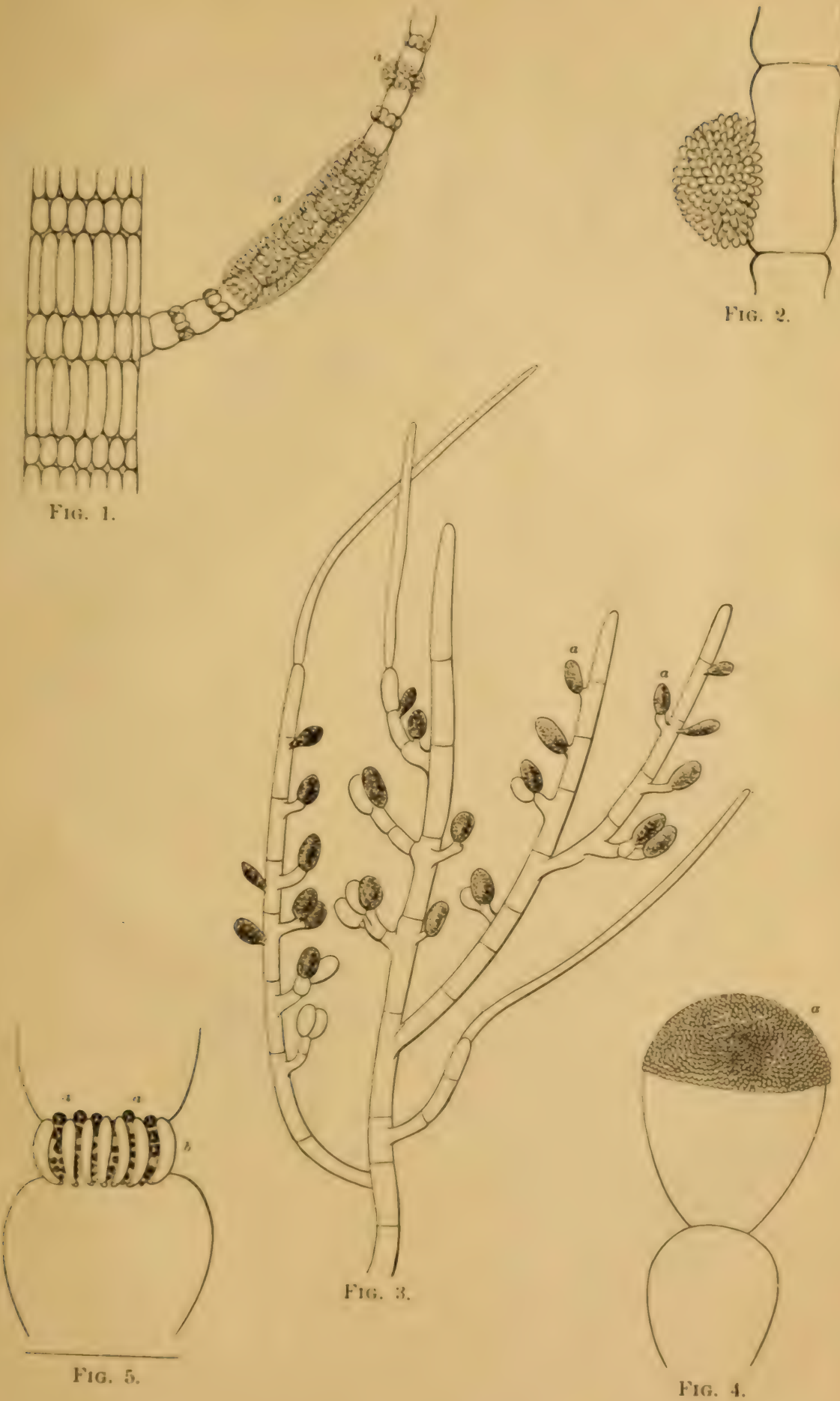





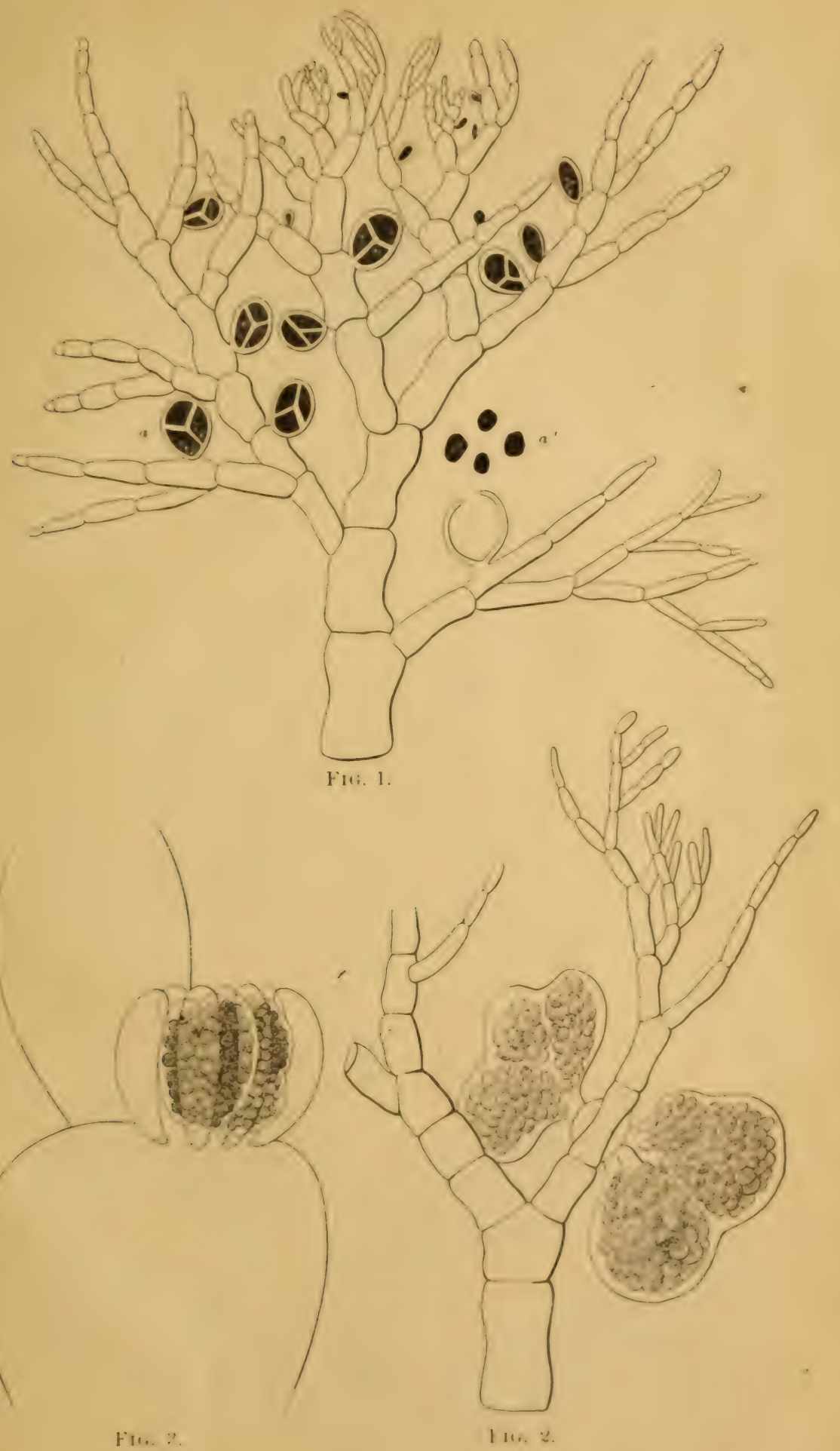





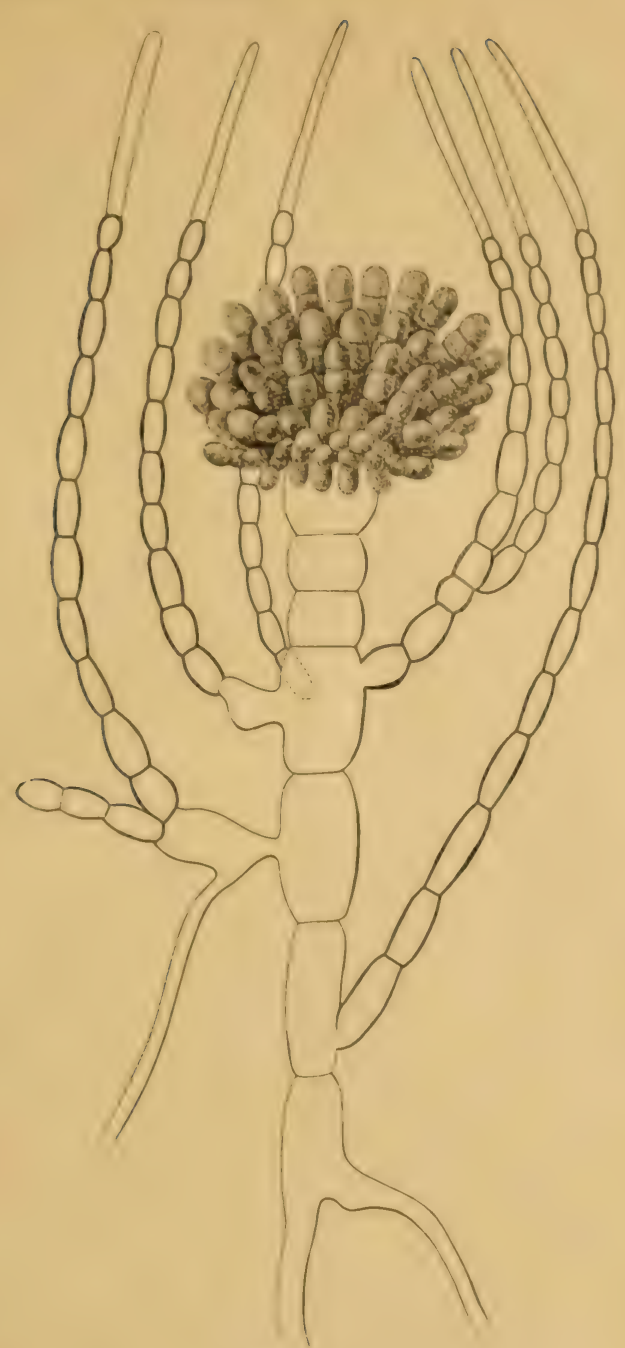

Fili. 1.

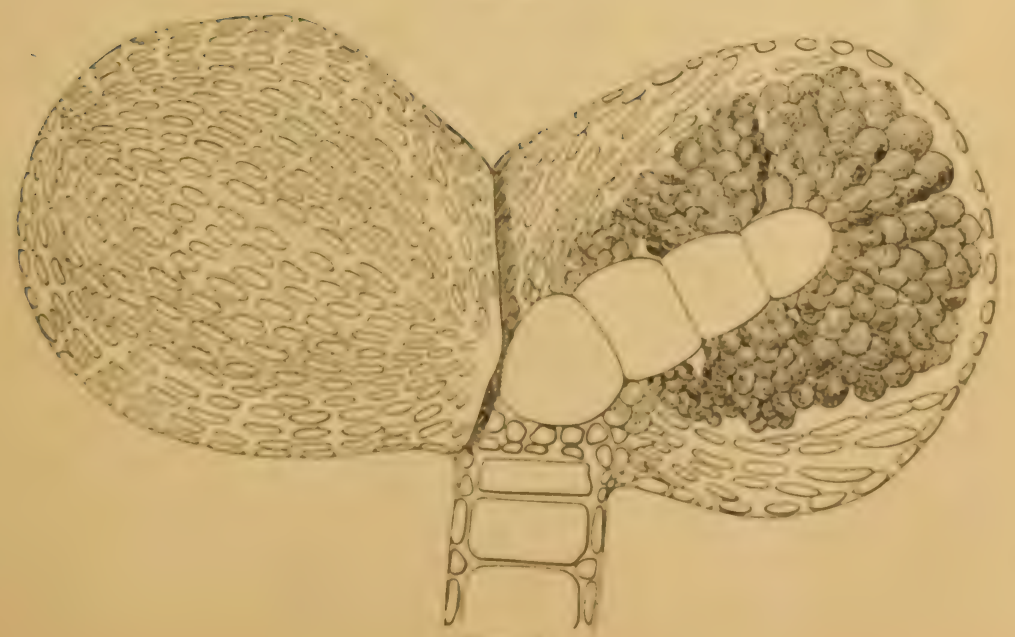

Fri, 2. 



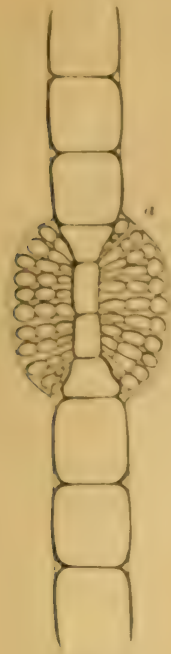

FIG. 4.

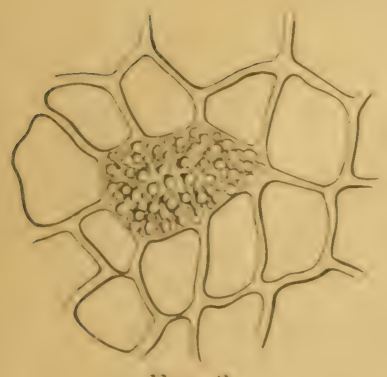

Fu: :3.

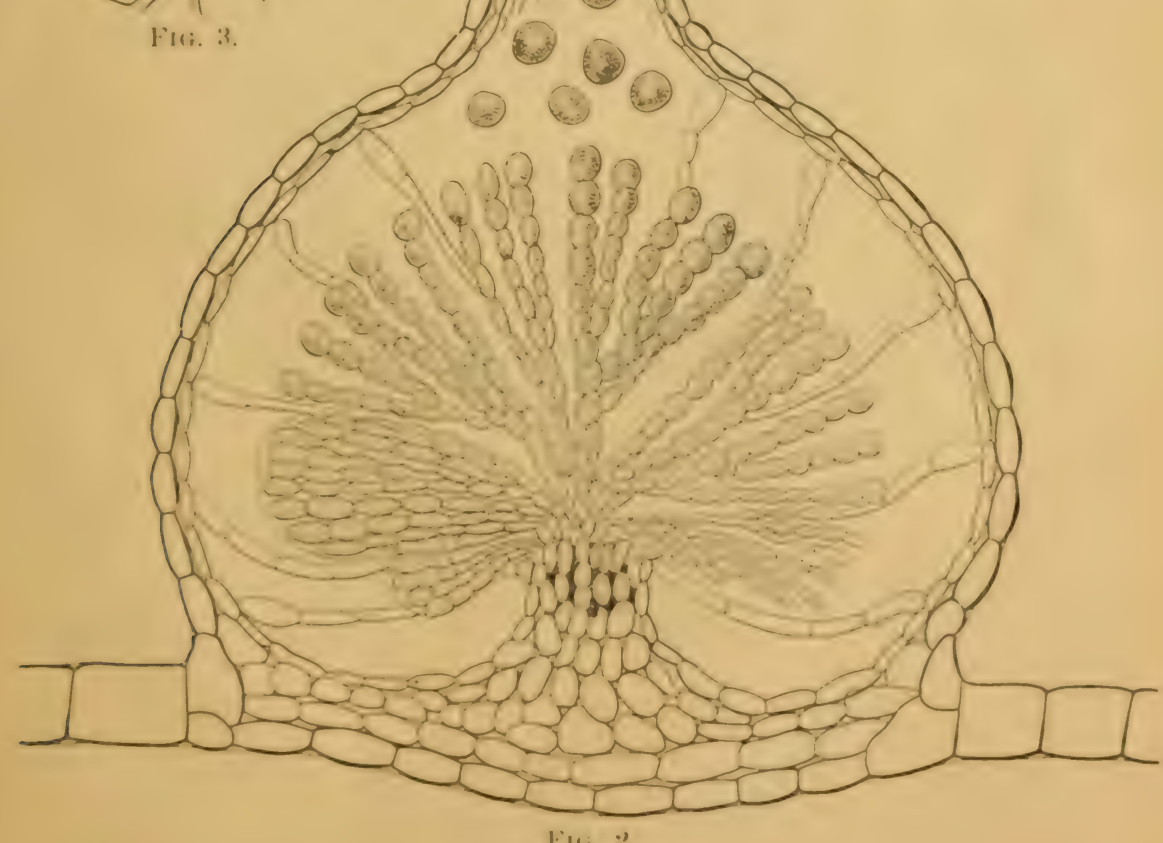

Fin.:

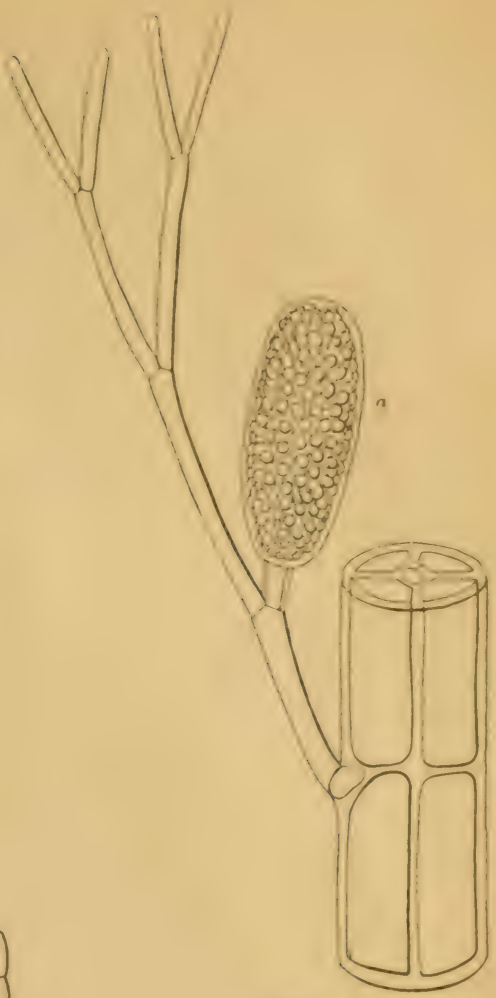

FICi. I. 



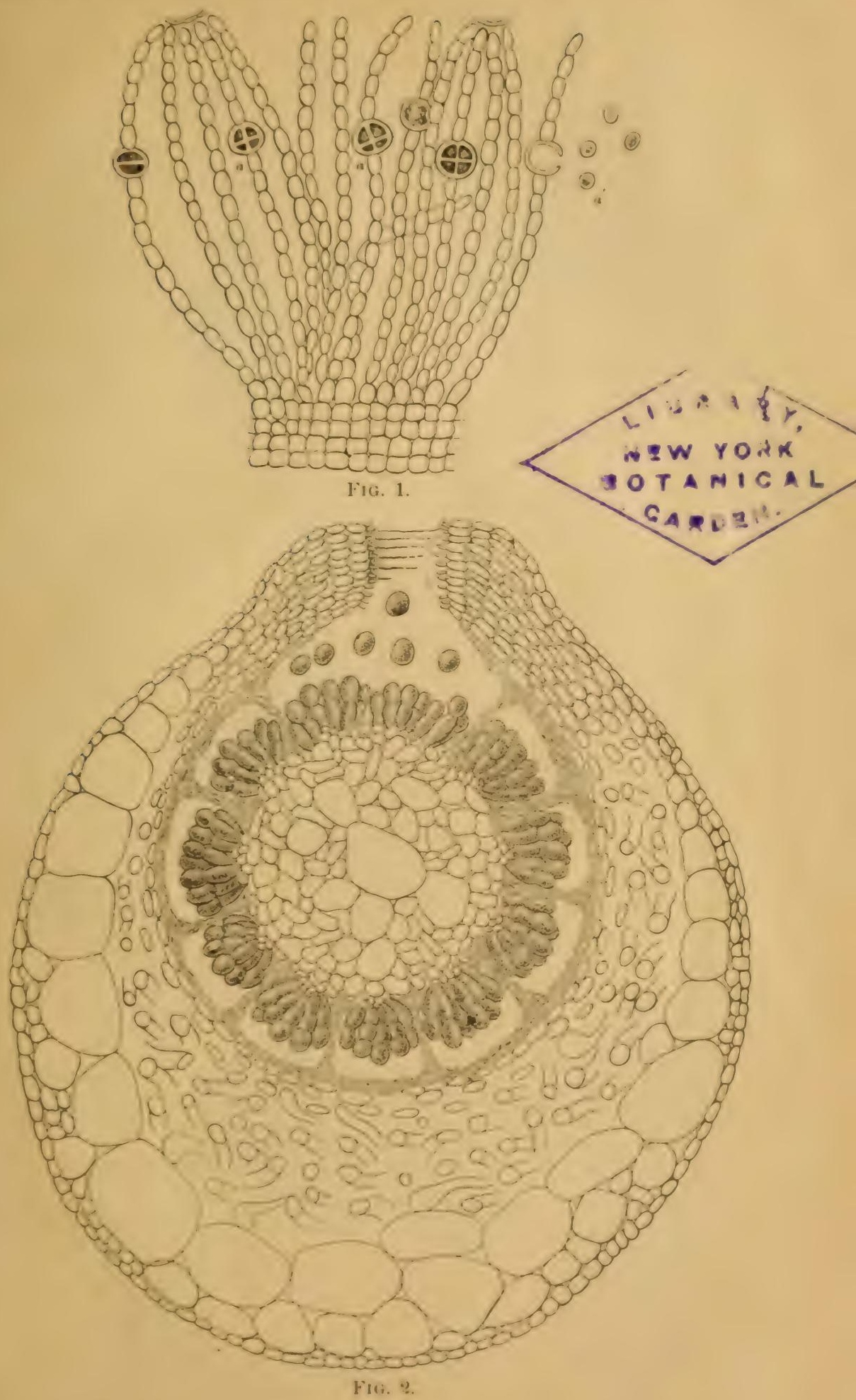





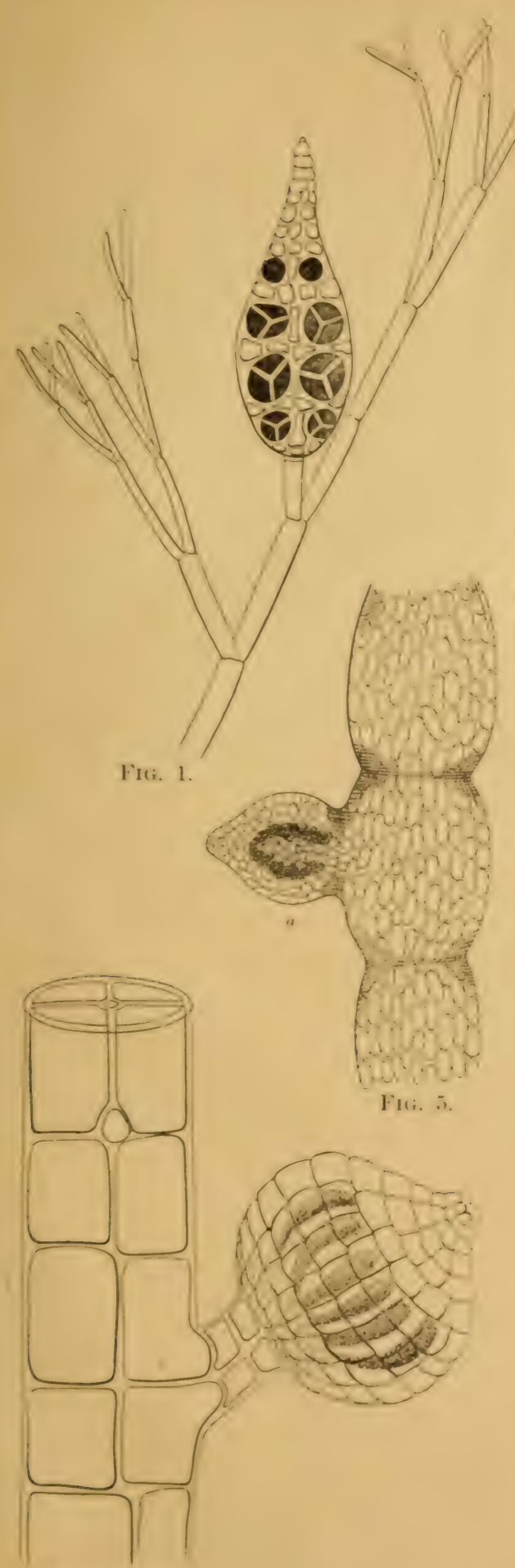

Iili. 4.

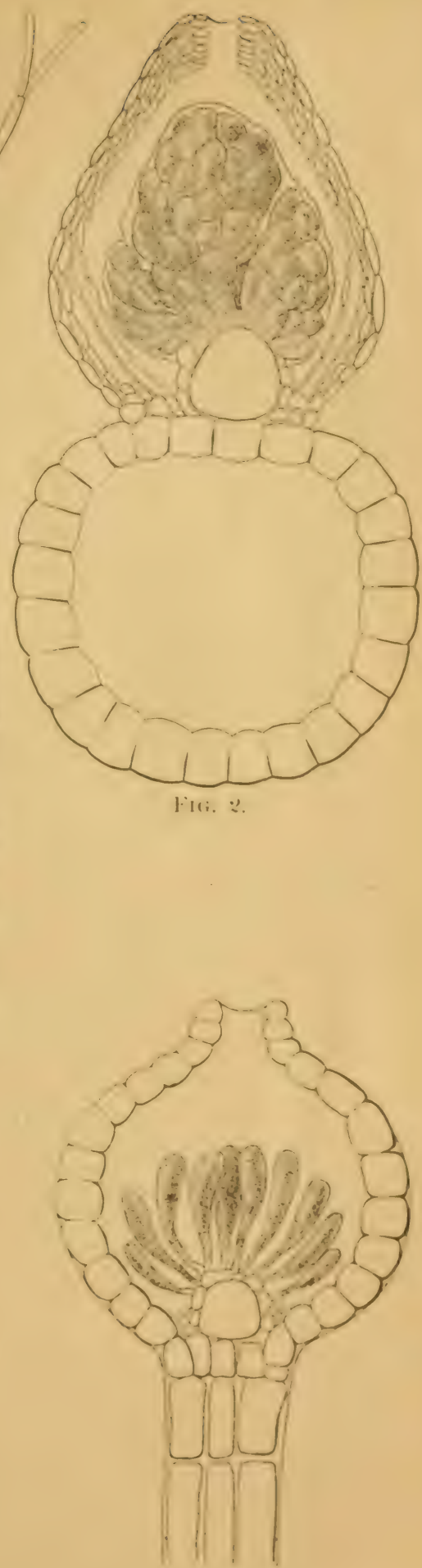

Fiti. :3. 

.

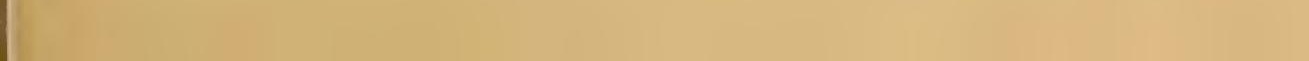





$$
\text { - }
$$




